\title{
Palynology of the Cenomanian to lowermost Campanian (Upper Cretaceous) Chalk of the Trunch Borehole (Norfolk, UK) and a new dinoflagellate cyst bioevent stratigraphy for NW Europe
}

Martin A. Pearce a, b,1 , Ian Jarvis b, Philip J. Ball c, Jiri Laurin d

a Evolution Applied Limited, 2 A P Ellis Road, Upper Rissington, Cheltenham, Gloucestershire GL54 2QB, UK

b Department of Geography, Geology and the Environment, Kings ' in University London, Penrhyn Road, Kingston-upon-Thames KT12EE, UK

c Geography, Geology and the Environment, Faculty of Natur al _clences, Keele University, Newcastle ST5 5BG, UK

d Institute of Geophysics, Academy of Sciences of the C. 'ecı. Republic, Boční II/1401, Praha 4, Czech Republic

${ }^{1}$ Email: info@evolutionapplied.com 


\section{Abstract}

A high-resolution palynological analysis of the Cenomanian to Lower Campanian in the Trunch borehole, Norfolk (southern North Sea basin) is documented. This constitutes the most detailed continuous record of organic-walled dinoflagellate cysts (dinocysts) from a single Upper Cretaceous section to date. A revised stratigraphic framework for the Trunch succession is presented, integrating regional marker bed lithostratigraphy, macrofossil biostratigraphy and carbon-isotope chemostratigraphy. Palynological events at Trunch are compared to published records with an emphasis on NW Europe, and a new stratigraphy comprising 65 dinocyst events is proposed. A geochronological age model based on radioisotopic and astrochronological ages $\urcorner f$ macrofossil biostratigraphic datum levels and global carbon-isotope e ${ }^{\circ} n^{\prime} s$ (CIEs) is used to revise the age calibration of the Upper Cretaceous $\delta^{13} C_{c a r b} C_{n} n r$ ate reference curve for the English Chalk, and to calculate absolute ages for the $p$ ly nological events with an accuracy judged to be $\pm 500 \mathrm{kyr}$. The palaeogeograp.ic distribution of key taxa is presented based on records obtained from th e sá lynodata database and additional records, summarised to 212 sites world via Endemic NW Europe, Northern Hemisphere wide and global species dis، ibutions are demonstrated. A taxonomic and detailed stratigraphic discussion is $p_{\mathbf{r}}$ vided to determine the likelihood that the events may be considered as global first c $r$ la ic appearance datum levels, or are local to regional lowest and highest or, irrences. Four global, 18 Northern Hemisphere and 43 NW Europe events are tabu' $t_{t}$, including 28 inceptions or extinctions of marker species; an additional 37 Vu._s may be of regional significance.

\section{Keywords:}

Dinoflagellate cysts; Biostratigraphy; Carbon isotopes; Chemostratigraphy; Upper Cretaceous; Chalk. 


\section{Introduction}

The Upper Cretaceous chalks of northwest Europe have been proven to be extremely rich in diversity and abundance of organic-walled dinoflagellate cysts; hereafter dinocysts (Clarke and Verdier, 1967; Kirsch, 1991; Prössl, 1992; Schiøler, 1992; FitzPatrick, 1995; Slimani, 2001a; Prince et al., 1999; 2008; Dodsworth, 2000, 2004a, b; Pearce et al., 2003, 2009; Surlyk et al., 2013; Olde et al., 2015a, b; 2016), which provide a means to potentially correlate successions to a very high resolution. The chalks of southern UK are particularly important as they were deposited in relatively shallow palaeo-water depths of 100 - 500 m (Hancock, 1975; Kennedy and Garrison, 1975; Mortimore et al., 2001) and have subsequently experien -ed minimal burial. Porosity - depth trends for normally compacted chalk frol ${ }^{\text {th }}$ ב North Sea (Mallon and Swarbrick, 2002), and fission track data and exhumatio. er timates (Japsen,1997;

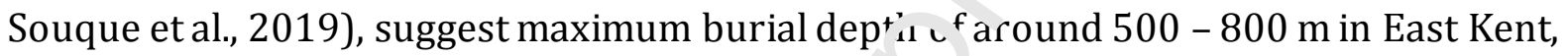
up to approximately 1500 - $2000 \mathrm{~m}$ for the East Yor s hire Chalk (Welch, 2015). Tectonic deformation is limited and exposurı $s \in$ nerally exhibit only very minor faulting.

The Cenomanian to Campanian is w: ely accessible at outcrop, where the macrofossil biostratigraphy can also $\iota^{\circ}$ employed, which has enabled detailed holostratigraphic studies (e.g. Jarvis e al., 1988a, b; Hampton et al., 2007; Thibault et al 2016). The UK chalks also fort. the basis for the high-resolution ( $1 \mathrm{~m}$ ) Cenomanian Lower Campanian carbonaı $\delta{ }^{2} \mathrm{C}$ reference curve of Jarvis et al. (2006) that has been widely employed as a gl $h_{\lambda_{i}}$ _andard for Late Cretaceous carbon isotope events (CIEs).

Due to the limitel su:agraphic extent of exposed sections and deformation of the upper parts of the Chă.". in Norfolk, the British Geological Survey (BGS; then known as the Institute of Geological Sciences) cored the Trunch borehole during $1974-1975$ to recover the Chalk at its most complete development in Britain. Almost $641 \mathrm{~m}$ of Cenomanian - ?Lower Maastrichtian chalk (as originally defined by the BGS; since reinterpreted as uppermost Campanian, Voigt et al., 2012) was recovered and classified according to the zonal and lithostratigraphical scheme of Peake and Hancock (1961).

Palynological (quantitative and absolute abundance) and stable isotope (carbonate $\delta^{13} \mathrm{C}, \delta^{18} \mathrm{O}$ ) results for the Cenomanian to Lower Campanian at Trunch, calibrated using lithostratigraphic marker beds, macrofossil biostratigraphy and carbon isotope chemostratigraphy, are presented here. Abundant and diverse dinocyst assemblages 
have been recovered, incorporating 184 species and subspecies. Biostratigraphic markers and other species displaying conspicuous events in the Trunch borehole will be discussed in detail. A new age model based on radioisotopic and astrochronological ages of macrofossil biostratigraphic datum levels and global CIEs, has been produced to determine absolute ages for the bioevents. The palaeogeographic extent of the marker taxa and their associated events will be assessed based on a comprehensive literature review, including taxonomic assessment of published data. A new palynological event stratigraphy for the Cenomanian to Lower Campanian is proposed.

\subsection{Previous palynological studies of the UK Chalk}

The first studies of Upper Cretaceous dinocysts from L nol and (Reade, 1839; White 1842, 1844; Mantell, 1845, 1850; Deane, 1849; Wilkir sı n 1849) were primarily taxonomic in nature and comprise descriptions of $\cdot \mathbf{d x} \cdot$ c ubserved in fragments of flint. Following a significant absence of published work, a ajuvenation of research occurred in the late 1960's, continuing to the present $c a^{\top}$.

Cookson and Hughes (1964) publis'، t le first account of the biostratigraphic distribution of dinocysts in the mid-Cre s seous of England. Their study of the Cambridge Greensand (Upper Albian Cenomanian) included several new taxa as well as detailed stratigraphic informatı 1 . I his work was succeeded by Davey and Williams (1966a, b), Davey et al. (1966) . nd Davey $(1969,1970)$ in a series of essentially taxonomic studies of dinocy -ts, tescribing many new genera and species, including some stratigraphic detain

The first attempı 'n $\because$. divide the Upper Cretaceous succession into a formal dinocyst biozonation _-1eme was made by Clarke and Verdier (1967) in a seminal paper on the Chalk of the Isle of Wight. Prince et al. (1999) showed that the original stratigraphic interpretation of Clarke and Verdier (1967) was flawed with respect to the position of the Santonian - Campanian boundary; nonetheless that work has remained the stratigraphically most comprehensive palynological analysis of the English Chalk, prior to the present work.

Following the pioneering research of Clarke and Verdier (1967), published palynological studies on other UK sections have been sparse. Although detailed in many cases, published studies have been based on sections with either a short stratigraphic range (Tocher and Jarvis, 1987, 1996; Jarvis et al., 1987, 1988a, b; FitzPatrick, 1995; 
Dodsworth, 1996, 2000), and/or a significant palaeoenvironmental overprint (Prince et al., 1999, 2008; Pearce et al., 2003, 2009).

Finally, the English Chalk continues to yield new species. Recently, four new genera, twenty-seven new species and subspecies, and four new combinations of dinocysts were described from southern and eastern England by Prince et al. (1999, 2008), Pearce (2010, 2018), Pearce et al. (2011) and Pearce and Williams (2018).

\section{Regional context of Trunch and the north Norfolk Chalk}

It has been long recognised that the Chalk of northern and southern England displays significant lithological and faunal differences (e.g. Ph.'ins, 1829; Mitchell, 1836; Barrois, 1876; Blake, 1878; Mortimer, 1878; Hill, 18?2· , ukes-Browne and Hill, 1903, 1904; Rowe, 1904; Wright and Wright, 1942). 'n - י thern England the Chalk rests on Upper Greensand or Gault Clay, which is $\mathrm{r}-$ piced by the Red Chalk (Hunstanton Formation) to the north (Figs 1 - 2) h. reneral, the chalks of southern England are weakly lithified and readily yield v el -preserved fossils (e.g. Smith and Batten, 2002), whereas northern chalk ${ }^{\circ}$ : $e_{\llcorner}$’nically cemented and exhibit prominent stylolites.

Around the Cenomanian - Turoni $\sim n$ boundary, the Plenus Marls (Fig. 2) of southern England and northern France are if p) aced in Lincolnshire and Yorkshire by the Black Band and Variegated Beds (Jefi rries, 1963; Wood and Mortimore, 1995; Hart, 2019). Flints typically appear in the Middle to Upper Turonian in the south and continue throughout the higher $C^{h} n / \mathrm{h}$ Juccession; they are absent from the mid-Santonian to Lower Campanian in . also differ between th ' 'wo regions: in the south they consist predominantly of blackcored small nodular flints; successions in the north are dominated by grey-cored thick tabular flints (Mitchell, 1836; Mortimore and Wood, 1986).

The differences between southern and northern chalks have resulted in the development of discrete lithostratigraphic schemes for the two areas (Wood and Smith, 1978; Mortimore, 1986; Whitham, 1991, 1993; Bristow et al., 1997; Mortimore et al., 2001; Rawson et al., 2001; Hopson, 2005; Mitchell, 2019; Figs 1 - 2). By contrast, as first noted by Barrois (1876), much closer similarities exist between the Chalk of Yorkshire and that of northern Germany, and between the Chalk of southern England and that of the Paris Basin. 


\subsection{Chalk provinces}

The different characteristics of the Chalk in southern and northern England has led to the concept of Southern and Northern Provinces with distinct lithological successions and fossil assemblages (Wood and Smith, 1978; Mortimore, 1983, 1986; Mortimore et al., 2001; Mortimore, 2014a), exemplified by those of Wiltshire, Hampshire, the Isle of Wight, Sussex, Surrey and Kent in the south, and of Lincolnshire and Yorkshire in the north (Fig. 1). Between these two regions lies a Transitional Province with mixed lithological and faunal characteristics that vary both geographically and stratigraphically. These changes are gradational and views cor rerning the placement and extent of the Transitional Province have varied widely. T' 1 e southern boundary has been placed as far south as London (e.g. Hopson, 2005 ; : "No timore, 2014b), broadly following an east - west line immediately to the ne rit. oi the Variscan Front (Busby and Smith, 2001), or as far north as Cambridgeshire ar.d _ Iffolk (e.g. Mortimore and James, 2015). Similarly, the placement of the northe $r$. li nit of the Transitional Province has ranged from southern Norfolk to offshr „ Lis: colnshire (Fig. 1).

We follow recent interpretations of , e extent of the Transitional Province (Mortimore and James, 2015; Mitcher: 2019) with the most significant facies shift occurring in south Cambridgeshir a $\mathrm{n}$ Suffolk (Fig. 1) around the position of the WNW - ESE trending Glinton Thrust, , major basement structure in the underlying Anglo Brabant Massif (Chadwick and IVans, 2005; Woods and Chacksfield, 2012). The distinct nature of the Chalk succrsc.: in Suffolk and wider East Anglia has resulted in the development of a reg:n stratigraphy of named marl and flint marker beds (Woods et al., 2012; Fig. 2). Bası J. on recent offshore borehole evidence (Mortimore and James, 2015), the Transitional Province extends northwards across Norfolk into the southern North Sea (Fig. 1), where successions continue to show greater similarity to those in the Chilterns than to the Northern Province facies of Lincolnshire and Yorkshire.

\subsection{Trunch borehole}

The Trunch borehole was drilled by the Institute of Geological Sciences (now British Geological Survey) in September 1974 - February 1975 on the eastern edge of Trunch village $\left(52.85953^{\circ} \mathrm{N} 1.40605^{\circ} \mathrm{E}\right)$, north Norfolk, eastern England (Fig. 1). The core site was located on an outcrop of the youngest preserved in-situ Chalk in the UK, close to the 
rafted Maastrichtian coastal sections at Trimingham and Sidestrand (Peake and Hancock, 1970; Whittlesea, 1991; Peake and Hancock, 2000; Mortimore et al., 2001; Voigt et al., 2012). The aim was to provide a stratigraphic reference section for regional Upper Cretaceous stratigraphy, including correlation to the southern North Sea (Gallois and Morter, 1976). The borehole penetrated $469 \mathrm{~m}$ of top Campanian to Cenomanian Chalk, thin Lower Cretaceous and Lower Jurassic sections, and terminated in Triassic Mercia Mudstone Group (Keuper Marl) at $651 \mathrm{~m}$ depth. The core obtained represents the stratigraphically most extended Upper Cretaceous continuous onshore record in the UK.

The Chalk succession at Trunch lies within the Transitiona.' Province, displaying a mixture of characteristics from both the Southern and Nol he $n$ Provinces, together with some distinctive features such as the highly atteru to $\lambda$ nature of the Cenomanian Lower Turonian succession (Newell et al., 2018). "In thinning is attributed to the presence of an underlying non-subsident Palaeozric : 'zsement high that limited accommodation space across north Norfolk $c u$ ir g the early Late Cretaceous. The lithofacies and marker bed stratigraphv $v^{c}$ th Cenomanian - Coniacian interval at Trunch shows the greatest similarity to : orthern Province successions (Wood et al. 1994; Fig 2). We therefore adopt the 'ithostratigraphic terminology of Wood and Smith (1978) for the studied interval in $\mathrm{h} \pm \mathrm{k}$ orehole, while noting that the Santonian Campanian interval shows inrı ' asing lithological divergence from both Southern and Northern Province Chalk suies sions.

\section{Stratigraphic fr a $m_{2}$.. ork of the Trunch borehole}

Detailed lithologic:' logs and preliminary faunal records made during the drilling of the Trunch cored borehole in 1974 - 1975 (Morter et al., 1975; http://scans.bgs.ac.uk/sobi_scans/boreholes/517419/images/12114521.html) provided the basis for a summary stratigraphy published shortly thereafter by Gallois and Morter (1976). The interstitial fluid chemistry of core samples was later reported by Bath and Edmunds (1981). The Upper Cretaceous of the core was subsequently reassessed, with substantial additional macrofossil collecting, the results of which were presented by Wood et al. (1994). Their litho- and biostratigraphic analysis has provided the framework for all subsequent work on the borehole, including the present study. A new detailed stratigraphic log, that includes the positions of key 
stratigraphically significant macrofaunal records and the named CIEs of Jarvis et al. (2006), is presented in Figs 3 - 4. Isotope curves that provide the basis for defining the chemostratigraphy at Trunch are plotted in Fig. $\mathbf{5}$ and the numerical data are presented in Supplementary Material Table 1.

Previous stratigraphic studies on the Trunch core have included nannofossil (Burnett, 1988, 1990), ostracod (Pyne et al., 2003; Whatley et al., 2003) and dinocyst biostratigraphy (Pearce, 2010, 2018), sequence stratigraphy (Grant et al., 1999), and strontium (McArthur et al., 1993a; McArthur et al., 1993b) and carbon-isotope chemostratigraphy (Scholle and Arthur, 1980; Jenkyns et al., 1994; Jarvis et al., 2002, 2006; Linnert et al., 2018). Trunch core samples have been us -d to construct and test chemostratigraphic reference curves for Late Cretaceous c $r r$ o $\mathrm{n}$ and oxygen stableisotopes (Scholle and Arthur, 1980; Jenkyns et al., 194, Iar vis et al., 2006) and strontium isotopes (McArthur et al., 1993b). The f ien.ental stratigraphy has been described by Bath and Edmunds (1981) and Pearre (.'000). The stable isotopic composition of carbonate-associated sulphur ( $\% 3$ SCAS $)$ through the Middle Cenomanian - Middle Turonian interval (505-495 rij wa presented by Owens et al. (2013).

\subsection{Chemostratigraphy}

\subsubsection{Carbon and oxygen isotopf $S$}

The seminal paper by Scho.' and Arthur (1980) that first demonstrated the application of carbon isoto ${ }^{2} \mathrm{~S} \mathrm{~L}$ : Cretaceous pelagic limestones for stratigraphic correlation included filtr ${ }_{-} \mathbf{a}_{-}{ }_{-}, \mathrm{W}$-resolution carbonate carbon $\left(\delta^{13} \mathrm{C}_{\mathrm{carb}}\right)$ and oxygen isotope $\left(\delta^{18} 0\right)$ curves fru... che Upper Cretaceous of "Norfolk" (i.e. the Trunch borehole). Bath and Edmunds (1 121 ) published carbon and oxygen isotope data for 11 samples from Trunch, and low-resolution $\delta^{13} \mathrm{C}_{\text {carb }}$ and $\delta^{18} \mathrm{O}$ profiles for the borehole were also illustrated by McArthur et al. (1993b fig. 4).

The Trunch $\delta^{13} \mathrm{C}_{\text {carb }}$ curve of Scholle and Arthur (1980 fig. 2) clearly displays the key characteristics of the Cenomanian - Campanian carbon isotope stratigraphy: (1) a minimum in the Lower Cenomanian; (2) rising values with a positive excursion and maximum spanning the Cenomanian - Turonian boundary; (3) falling values to a pronounced minimum around the Turonian - Coniacian boundary; (4) rising values to a second lower-amplitude maximum around the Santonian - Campanian boundary; (5) falling values above, with a pronounced negative excursion in the Upper Campanian. 
These trends were interpreted to represent synchronous changes in the global carbon cycle, and with the acquisition of multiple increasing high-resolution data sets worldwide, carbon stable-isotope chemostratigraphy has become generally accepted as a method for the regional to global correlation of Upper Cretaceous strata (Wendler 2013 and references therein). By contrast, the Trunch $\delta^{18} 0$ curve displays less variation, with a general trend of rising values through the Upper Cretaceous and the highest values in the Upper Campanian (Scholle and Arthur, 1980 fig. 3).

The first detailed carbon and oxygen stable-isotope study of the English Chalk by Jenkyns et al. (1994) included data for the Campanian of the Trunch borehole. These data were used by Jarvis et al. (2002) to demonstrate a robust -arbon isotope correlation of Campanian strata between the Tethyan (El I. of iunisia; Bidart, France) and Boreal (Trunch) realms that has been confirmed 'oy cu'sequent studies (e.g. Voigt et al., 2010; Linnert et al., 2018). This work was e.te. aed by Jarvis et al. (2006) who presented new carbonate carbon and oxygen isotr pe data for the Cenomanian Santonian of Trunch (Fig. 5). These were int $\mathrm{g}$. a ed the $\delta^{13} \mathrm{C}_{\text {carb }}$ results with the

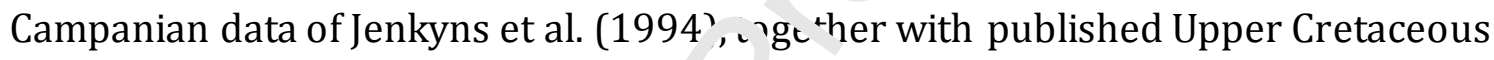
records from East Kent, Culver Cliff Isle $\mathrm{f}$ Wight, Speeton North Yorkshire, Banterwick Barn Berkshire, Seaford Head and Ea.tbourne East Sussex. Using these data, Jarvis et al. (2006) constructed a composite a gf -c xlibrated carbon isotope reference curve and erected a formal CIE chemostra igraphy for the Late Cretaceous. The positions of the named CIEs in the Trunch ce re re indicated in Figs 3 - 5.

The carbon isotope mit:-nce curve for the Cenomanian - Campanian based on the English Chalk (Jarvis . + a.., 2006), which utilised data from Trunch for the Turonian Coniacian boundary is _ rval and the uppermost Santonian - Upper Campanian, has proved to provide a sound basis for the global correlation of Upper Cretaceous strata (e.g. Lamolda and Paul, 2007; Voigt et al., 2007; Sprovieri et al., 2013; Uramoto et al., 2013; Joo and Sageman, 2014; Jarvis et al., 2015; Thibault et al., 2016; Wohlwend et al., 2016; Jones et al., 2018; Linnert et al., 2018; Püttman et al., 2018; Razmjooei et al., 2018), including the improved definition of stage boundaries (Kennedy and Gale, 2006; Lamolda et al., 2014; Uličný et al., 2014; Thibault et al., 2016).

Work on the carbon isotope stratigraphy of the Campanian - Maastrichtian boundary succession on the north Norfolk coast, the Maastrichtian GSSP at Tercis les Bains France and sections at Gubbio Italy (Voigt et al., 2012) demonstrates that, 
contrary to previous interpretations (Wood et al., 1994), the top of the Trunch core does not include the Maastrichtian (base Maastrichtian placed at the base of the Belemnella obtusa Zone, following Gradstein et al., 2012), but falls a short distance below the stage boundary. Nonetheless, the English $\delta^{13} \mathrm{C}_{\text {carb }}$ record corresponds closely to profiles obtained from north Germany, Denmark, western France and central Italy, potentially enabling an extension of the Boreal Upper Cretaceous carbon-isotope reference curve to the Cretaceous - Paleogene boundary. Most recently, a high-resolution isotope study of the Late Campanian CIE (LCE) interval at Trunch (Linnert et al., 2018) confirmed the results of Scholle and Arthur (1980) and Jenkyns et al. (1994) that show a 0.7\%o negative $\delta^{13} \mathrm{C}_{\text {carb }}$ anomaly at this level.

\subsubsection{Strontium isotopes}

The strontium isotope stratigraphy (SIS) of th. 1 ' 'l1 ch borehole published by McArthur et al. (1993b) provided the first well-co' $15\left\llcorner\right.$ ' 7 ined ${ }^{87} \mathrm{Sr} /{ }^{86} \mathrm{Sr}$ reference curve for the Upper Cretaceous, particularly for the C sn acian - Campanian interval, which shows monotonic increasing isotope ra'ss. Tata for the Cenomanian - Lower Campanian interval are plotted in Fig. $\mathbf{3}$. Results from the Trunch study have been

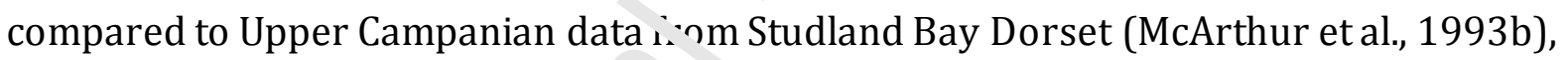
Campanian - Maastrichtian bounca $\mathrm{y}$ values from Lägerdorf and Kronsmoor northern Germany (McArthur et al., 199 ${ }^{\circ}$ ?. and to a radiometric age-calibrated strontium isotope reference curve for the Late r.r.taceous of the US Western Interior (McArthur et al., 1994). The last of these $=7 n_{-}$butes the main data for constructing a SIS global reference curve for t. ${ }^{2} L_{2} \_$C Cretaceous (Howarth and McArthur, 1997; McArthur et al., 2001, 2012).

Comparison between the Trunch and Western Interior ${ }^{87} \mathrm{Sr} /{ }^{86} \mathrm{Sr}$ data (McArthur et al., 1993b, 1994) shows good agreement for the Coniacian - Lower Campanian (Fig. 5), but values diverge significantly in the Upper Turonian below the Navigation Hardground ('Top Rock'). The Trunch ${ }^{87} \mathrm{Sr} /{ }^{86} \mathrm{Sr}$ values are anomalously high by up to $70 \times 10^{-6}$ for $40 \mathrm{~m}$ below the hardground, with the greatest offset around the level of the 'Chalk Rock' (Hitch Wood CIE). Marine ${ }^{87} \mathrm{Sr} /{ }^{86} \mathrm{Sr}$ ratios of around 0.7073 at this stratigraphic level are confirmed by isotope data from barite in ocean drilling cores (Mearon et al., 2003), compared to the measured value of 0.7074 at Trunch. Strontium isotope trends are again concordant for the mid-Turonian - Cenomanian portions of the 
Trunch and Western Interior curves (Fig. 5), but with an offset to higher ${ }^{87} \mathrm{Sr} /{ }^{86} \mathrm{Sr}$ values at Trunch, particularly in the nodular chalk and hardground facies below $495 \mathrm{~m}$.

Variable offsets to elevated ${ }^{87} \mathrm{Sr} /{ }^{86} \mathrm{Sr}$ values in the Upper Turonian at Trunch have been attributed to diagenesis (McArthur et al., 1993b; McArthur, 1994), possibly a result of the hardgrounds in this interval acting as permeability barriers that prevented the expulsion of ${ }^{87} \mathrm{Sr}$-enriched compactional fluids, which precipitated isotopically anomalous cements in this part of the section. Present-day porewater profiles indicate mixing between meteoric water infiltrating the top of the Chalk and connate seawater trapped in pore spaces since deposition (Bath and Edmunds, 1981), but Chalk pore fluids typically display more radiogenic signatures than their a 'companying matrix carbonate, due to the preferential release of Sr from the clcy $r$ inerals during diagenesis and weathering (Shand et al., 2009). For comparisor, ${ }^{27} \mathrm{Sr},{ }^{86} \mathrm{Sr}$ ratios in vein-fill calcites

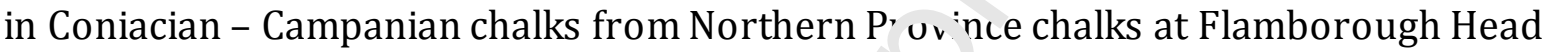
are also anomalously high, up to 0.7103 , compare d tu matrix values of $0.7073-0.7076$ (Faÿ-Gomord et al., 2018). Consequently, Trı n -h Upper Turonian Sr-isotope values are considered to be altered and cannot be $\mu ? \mathrm{a}$ : derive accurate age data.

The Upper Santonian - uppermost $\iota \cdot \operatorname{mpanian}{ }^{87} \mathrm{Sr} /{ }^{86} \mathrm{Sr}$ profile at Trunch (Fig. 5) corresponds closely to that obtained inm Lägerdorf - Kronsmoor, north Germany (McArthur et al., 1993a), with the 2 .cf ption of a small interval below the level of the

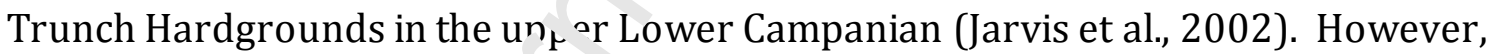
more generally at Trunch, ängt netic alteration of the chalks (which are better cemented than their Germa . -quivalents), has increased ${ }^{87} \mathrm{Sr} /{ }^{86} \mathrm{Sr}$ ratios in the nannofossil matrix by $3 \imath=10^{-6}$ compared to values derived from macrofossils at the same stratigraphic lew:- (McArthur et al., 1993b; Fig. 5). This diagenetic effect may be corrected by subtracting 30 x $10^{-6}$ from the ${ }^{87} \mathrm{Sr} /{ }^{86} \mathrm{Sr}$ values of the Norfolk nannofossil samples (McArthur et al., 1993a; McArthur, 1994).

The consistent monotonic increasing ${ }^{87} \mathrm{Sr} /{ }^{86} \mathrm{Sr}$ trend of both European Chalk sections brings into question the numerical age model for the Lower - Middle Campanian in the US Western Interior used to construct the 2012 Geological time scale (Gradstein et al., 2012), which generates a marked dog-leg pattern in the age-calibrated Sr-isotope profile (McArthur et al., 2016 fig. 3). This demonstrates how Sr-isotope data provide insights into stratigraphic completeness (McArthur et al., 2012, 2016) and, in 
this case, raise an issue that will need to be addressed in future iterations of the geological timescale.

\subsubsection{Sulphur isotopes}

Carbonate associated sulphur isotopes ( $\left.\delta^{34} \mathrm{~S}_{\mathrm{CAS}}\right)$ have been studied from the Middle Cenomanian - basal Middle Turonian interval at Trunch and show a near-linear upwards increasing trend from 19 to $22 \%$ o $\delta^{34} S_{\text {CAS }}$ between 505.0 and $495.0 \mathrm{~m}$ (Owens et al., 2013). This is consistent with data from northern and southern England (South Ferriby, Eastbourne), Italy (Gorgo Cerbara, Raia del Pedale), and the US Western Interior (USGS Portland No. 1 core) that indicate rising $\delta^{34} \mathrm{~S}_{\mathrm{A}} \mathrm{S}: \eta$ the Late Cenomanian and a maximum in the Turonian (Ohkouchi et al., 1999; AG `m, et al., 2010; Owens et al., 2013), several hundred thousand years after the max $n^{\prime} \cdot 1 m$ of $>5 \%$ o $\delta^{13} C_{\text {carb }}$ characterising the CTBE (e.g. Jarvis et al., 2011).

The $\delta^{34}$ Scas positive excursion may be attributza -7 increased deposition of isotopically light pyrite in expanded areas of is ea nic seafloor euxinia during OAE2. The stratigraphic offset with respect to the w itı carbon isotope excursion principally reflects the dramatically different residt. 'ce times of C and S $<150 \mathrm{kyr}$ and around 15 Myr, respectively; Walker, 1986; Lécu:rer, 2016) in the oceans.

\subsection{Lithostratigraphy, mar. ofossil biostratigraphy and carbon isotope stratigraphy}

An independently drmivizand fully documented high-resolution stratigraphic framework is essentıc ${ }^{\prime} t u=$ unstrain the palynological data. Here, we review the lithostratigraphy and acrofossil biostratigraphy of the core based on Wood et al. (1994), revised in the light of later work. These data are integrated with the carbonisotope chemostratigraphy of Jarvis et al. (2006) to precisely place the dinocyst records presented herein. The stratigraphic framework is summarised in Figs 3 - 5.

\subsubsection{Albian - Cenomanian boundary}

The base of the Upper Cretaceous (Cenomanian) in the Trunch borehole is placed at the facies change to chalk at $512.22 \mathrm{~m}$ (Fig. 3), marking the base of the Ferriby Chalk Formation (Chalk Group) of Wood and Smith (1978). This occurs above a complex phosphatised hardground surface at the top of a highly condensed $(63 \mathrm{~cm})$ Lower 
Albian Carstone Formation (oolitic ferruginous sandstone) to Upper Albian Hunstanton Formation (Red Chalk) succession (Gallois and Morter, 1976; Wood et al., 1994).

The Albian Red Chalk consists of red-brown coloured, quartz- and chert-rich pebbly intraclastic limestones with a microbially laminated upper surface (cf. Jeans, 1973, 1980; Frutexites(?) Andrews et al., 2015) and common Neohibolites and Inoceramus fragments. In its type section at Hunstanton on the north Norfolk coast (Fig. 1), the top of the Red Chalk is considered to be of Late Albian Callihoplites auritus ammonite Subzone (top Mortoniceras inflatum Zone) age, with an overlying thin red marl that is possibly earliest Cenomanian (Owen, 1995; Mitchell, 2019). The uppermost Albian Stoliczkaia dispar ammonite Zone (Mortoniceras (Subschloenbu-rhia) rostratum Pleurohoplites briacensis Subzones) is absent, so significan. st atigraphic gaps are indicated between the top of the Red Chalk and the ma! a'd also between the marl and

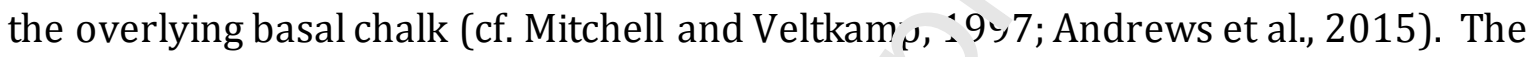
marl is absent in the more attenuated Trunch sucres.'on.

\subsubsection{Cenomanian}

\section{Lower Cenomanian (512.22 - 50५.30 m,}

The basal unit of the Chalk at ' $r{ }^{\prime} \iota^{\prime} \mathrm{h}$ is the Paradoxica Bed (Peake and Hancock, 1961; Jeans, 1980), a hardgrou nd , ith a convolute mineralised surface at $511.91 \mathrm{~m}$ (Fig. 3). The bed consists of a vell-cemented white to cream chalkstone (cf. Bromley and Gale, 1982) incorporaing many small quartz and chert pebbles, and is highly fossiliferous throug' ${ }^{\prime} \mathrm{Lu}^{+} \mathrm{w}$ th abundant sponge remains, Aucellina and inoceramid bivalve fragments, and $\mathrm{b}$ rachiopods. The surface is glauconitised, phosphatised and bored. This distinctive bed, characterised by abundant Thalassinoides paradoxica Woodward burrows (Kennedy, 1967), is well exposed at Hunstanton (Fig. 1) and likely corresponds to the lower Neostlingoceras carcitanensis ammonite Subzone of the Lower Cenomanian Mantelliceras mantelli Zone (Peake and Hancock, 1961, 1970; Jeans, 1980; Gale and Friedrich, 1989; Gallois, 1994; Mortimore et al., 2001).

The succession between the Paradoxica Bed hardground and an erosion surface at $509.80 \mathrm{~m}$ is assigned to the Lower Cenomanian Mantelliceras mantelli Zone, $N$. carcitanensis to M. saxbii Subzones (Wood et al., 1994). Within this interval, the basal bioclastic chalks rich in Inoceramus crippsi crippsi Mantell correspond to the First 
(Lower) Inoceramus Bed of the Northern Province succession (Wiltshire, 1869; Hill, 1888; Peake and Hancock, 1961, 1970; Gaunt et al., 1992), which places these beds within the Sharpeiceras schlueteri Subzone of the mid-M. mantelli Zone (Mortimore et al., 2001; Wright and Kennedy, 2015; Figs 2 -3). Our stratigraphically lowest productive palynology sample originates from the base of the First Inoceramus Bed.

Inoceramus ex gr. virgatus Schlüter is first recorded in the nodular chalks above the erosion surface at $509.80 \mathrm{~m}$, and the species is abundant in the shell bed at $509.32 \mathrm{~m}$, up to a planar hardground surface at $508.82 \mathrm{~m}$ (Fig. 3). This interval likely corresponds to the ubiquitous acme-occurrence of this species in the lower part of the uppermost Lower Cenomanian Mantelliceras dixoni Zone (Ernst et al., 19ऽ?: Gale, 1995; Mitchell et al., 1996; Mortimore et al., 2001; Jarvis et al., 2006; Wrighı गn'، Kennedy, 2017). The omission/erosion surfaces at 509.80, 509.32 and 508 8. m m correlate to marker horizons M4 - M6 of Gale (1989) at Folkestone, with M4 co' it nunding to the Sub-dixoni Erosion Surface of Wright and Kennedy (2017), and M6 with the Dixoni Limestone. The small minimum in the $\delta^{13} \mathrm{C}_{\text {carb }}$ profile at this level co $r$ e ates to the Virgatus Beds CIE (VBE, Figs 3, 5).

The above correlation is supportea $\mathrm{v}$ v records of Orbirhynchia mantelliana (J. de C. Sowerby) brachiopods at 508.40 ana $508.43 \mathrm{~m}$, a short distance above a planar hardground surface, indicating the r o ition of the lowermost band of 0 . mantelliana (Om Band 1, cf. Gale, 1989). A _ malı negative $\delta^{13} \mathrm{C}_{\text {carb }}$ excursion at $508.0 \mathrm{~m}$ corresponds to the Mid-dixoni CIE (Fig. 3 ) : i bove this, in the absence of any definitive marker taxa, the fossiliferous bioturb-tec inarly chalks, the dark marl between 507.05 and $507.12 \mathrm{~m}$, and the hardground ${ }^{3} a_{\ldots-2}$ ent below 506.30, are assigned to the upper M.dixoni Zone (Figs 2 - 3).

\section{Middle Cenomanian (506.30 - 502.32 m)}

A phosphatised hardground surface at $506.30 \mathrm{~m}$ is overlain by coarse-grained gritty and calcarenitic chalks with abundant fossil debris and black phosphatic pebbles; this facies continues upwards to $505.21 \mathrm{~m}$ (Fig. 3). These sediments are a development of the lower Middle Cenomanian Totternhoe Stone Member (Whitaker, 1865; Wood etal., 1994; Hopson, 2005), a distinctive unit in the Chiltern Hills of Berkshire and Hertfordshire, and in Cambridgeshire (= the Grey Bed of Hill, 1888, recognised in Lincolnshire and Yorkshire; also referred to locally as the Chilton Stone or Burwell 
Rock). The Totternhoe Stone is considered to be broadly equivalent to the Cast Bed of southern England (Price, 1877; Gale, 1989; Mitchell et al., 1996; Mortimore et al., 2001), i.e. close to the base of the Turrilites costatus ammonite Subzone, Acanthoceras rhotomagense Zone (Wright and Kennedy, 2017), but some distance above the base of the Middle Cenomanian (Cunningtoniceras inerme Zone; Fig. 2).

The lithostratigraphic correlation is supported by the carbon isotope stratigraphy. A marked increase in the slope of the $\delta^{13} \mathrm{C}_{\text {carb }}$ profile and a small positive excursion within the Totternhoe Stone at Trunch (Fig. 5) is correlated to Mid-Cenomanian Event I (MCEI). In the more expanded succession at Speeton (Yorkshire) this CIE is characterised by a double peak (Mitchell et al., 1996; Mitchell, ?019), one at the base of the Totternhoe Stone (MCEIa), the other in the marly inter al at its top (MCEIb). The latter yields the belemnite Praeactinocamax primus (?lainv lle), indicating the position of the P. primus bed, a faunal event horizon that co I $\mathrm{r}$ ponds to the base of the Cast Bed (couplet C1) and the position of MCEIb in southern L. 'gland (Gale, 1995; Mitchell et al., 1996; Wilmsen, 2003; Mitchell, 2005; Wilmst $n$ et al., 2007). In the more condensed section at Hunstanton, P. primus occurs a th base of the Totternhoe Stone, demonstrating the presence of a hiatus a the base of the bed that cuts out older sediments representing MCEIa. Base.' on the similarities to the succession at Trunch it is likely that the small positive $\delta^{13} \mathcal{J}$ ar excursion here represents MCE1b of basal $A$. rhotomaganese Zone age (Fig ? ? although higher resolution sampling is required to confirm this.

Elsewhere, the sub-T^t๘: nhoe Stone erosion surface locally cuts down into the underlying chalk, for . iı $_{0}$-nannels (Gallois, 1988; Bristow, 1990; Hopson, 1992; Wood, 1996) with sediment $: 1$ s that may contain remanié fauna from multiple levels in the low Middle Cenomanian and from the uppermost Lower Cenomanian M.dixoni Zone (Wright and Kennedy, 2017). Comparable channels have been interpreted in seismic profiles from offshore north Norfolk (Mortimore and James, 2015). The basal Middle Cenomanian Cunningtoniceras inerme Zone, which includes the second of three $O$. mantelliana bands ( $\mathrm{Om}$ Band 2), is likely missing at the hiatus on the sub-Totternhoe Stone erosion surface at Trunch.

The bed above the Totternhoe Stone was correlated by Wood et al. (1994) to the Ammonite Bed (Bed IV of Bower and Farmery, 1910) of the Northern Province succession (Fig. 3; Gaunt et al., 1992; Owen, 1992; Mortimore et al., 2001), and its 
surface at $504.33 \mathrm{~m}$ to the P/B Break or "mid-Cenomanian non-sequence" of Carter and Hart (1977), characterised regionally by a sharp increase in the foraminifera planktic/benthic ratio and a flood of keeled planktonic species. This marker horizon occurs a short distance below the top of the Turrilites costatus Subzone in southern England (Wright and Kennedy, 2017). Upper O. mantelliana band sediments (Om Band 3), which immediately underlie the P/B break elsewhere, might be unpreserved or incorporated in the Ammonite Bed (cf. Gaunt et al., 1992). A $\delta^{13} \mathrm{C}_{\text {carb }}$ minimum above the foraminifera change defines the P/B Break CIE (PBE in Fig. 3). This is correlated to the Ammonite Bed here, but sampling resolution is inadequate to place the event with high confidence.

The interval from 504.33 to 503.58 is rich in brachion ds including Concinnithyris and Terebratulina, indicating a correlation with the lc $w$ $r$ r art of the Lower Pink Band, lower Turrilites acutus Subzone, of the Northern P ov ince Chalk stratigraphy (Bower and Farmery, 1910; Wright and Wright, 1942; Wc ou 'nd Smith, 1978; Whitham, 1991; Gaunt et al., 1992; Wood et al., 1994). The nc delc $r$ marly chalks above this terminate with a hardground surface at $502.32 \mathrm{~m}$ (. $\mathrm{g}$. ?), taken to mark the top of the $A$. rhotomagense Zone (Wood et al., 1994).

A $1 \mathrm{~cm}$ marl containing abundan -mall Pycnodonte spp. oysters overlying a hardground surface at $502.32 \mathrm{~m} \mathrm{mad} \mathrm{k}$; the base of the uppermost Middle Cenomanian, Acanthoceras jukesbrownei $\mathrm{Zn}_{n_{1}}$ ?. This bed equates to the Nettleton Pycnodonte Marl (Gaunt et al., 1992; Wood, 179 ; = Gryphaea bed of Bower and Farmery, 1910), and the Pycnodonte Event of no ${ }^{\text {th }} \in{ }_{. .1}$ Germany (Ernst et al., 1983). The latter is characterised by rare A. jukesbrowı ( ${ }^{\prime}$ ath) ammonites, while elsewhere in England the base of the A. jukesbrownei Zone,_-lds common 'Inoceramus' ex gr. atlanticus (Heinz), a species that is known from the Pycnodonte Marl in northern England (Gaunt et al., 1992).

The $30 \mathrm{~cm}$ of hard nodular chalk immediately above the Pycnodonte Marl is interpreted to be a condensed development of the Nettleton Stone of the Northern Province (Gaunt et al., 1992), equivalent to Jukes-Browne Bed 7 (JB Bed VII; JukesBrowne and Hill, 1903) at Dover and throughout southern England (Woods et al., 2012). The top of the Middle Cenomanian, defined by the last occurrence of $A$.jukesbrownei, is located a short distance above the top of JB Bed VII (Wright and Kennedy, 2017). A small negative $\delta^{13} \mathrm{C}_{\text {carb }}$ shift occurs in the Pycnodonte Marl at Trunch and in more expanded form below the Nettleton Stone at Speeton. This is an expression of the MCEII 
CIE, a characteristic A. jukesbrownei Zone marker (Mitchell et al., 1996; Jarvis et al., 2006; Mitchell, 2019).

\section{Upper Cenomanian (502.32 - 500.07 m)}

The base of the Upper Cenomanian Calycoceras guerangeri Zone is placed the top of the Nettleton Stone at 502.00 m (Fig. 3). The overlying marly chalks correspond to the Upper Pink Band of the Northern Province stratigraphy (Bower and Farmery, 1910; Gaunt et al., 1992; Wood et al., 1994). A positive $\delta^{13} \mathrm{C}_{\text {carb }}$ shift in this bed is correlated to the Jukes-Browne CIE (JBE in Fig. 3) that spans the A. jukes-brownei - C. guerangeri Zone boundary elsewhere (Jarvis et al., 2006). A glauconitis _ t convolute hardground surface at $501.10 \mathrm{~m}$ caps a well-developed $25 \mathrm{~cm}$ thick sty 'olit c chalkstone. The negative $\delta^{13} \mathrm{C}_{\text {carb }}$ excursion in this bed is equated to the Mo ument CIE (ME in Fig. 3). The interval between the glauconitised hardground su uface and an unmineralised convolute hardground at $500.51 \mathrm{~m}$ was assigned to th 2 Metoicoceras geslinianum ammonite Zone by Wood et al. (1994). A mariy plexus from 501.02 to $500.96 \mathrm{~m}$ represents the thin, north Norfolk equival€. t of the Plenus Marls (Jefferies, 1963 fig. 10; Wood et al., 1994; Voigt et al., 2006), a. d he glauconitised hardground, below, the subPlenus erosion surface and base of he Welton Chalk Formation of the Northern Province succession (Wood and S ni... 1978; Hart et al., 1991; Whitham, 1991; Dodsworth, 1996).

There is no development,$f$ organic-rich mudstones of Black Band facies (considered to be equivale. $t t^{\prime}$ ) uppermost Plenus Marls and Melbourn Rock of southern England) that tha :acterise the basal Welton Chalk throughout the Northern Province and most of thr North Sea Basin (Dakyns and Fox-Strangeways, 1886; Rowe, 1904; Jefferies, 1963; Wood and Smith, 1978; Jeans, 1980; Gaunt et al., 1992; Johnson and Lott, 1993; Wood and Mortimore, 1995; Dodsworth, 1996; Wood et al., 1997; Sumbler, 1999; Mitchell, 2000; Mortimore et al., 2001; Hart, 2019). The marly succession at the base of the Welton Chalk that incorporates the Black Band (the 'Variegated Beds' of Wood and Mortimore, 1995; Wood et al., 1997) was referred to the Flixton Member by Jeans (1980; Jeans et al., 1991) and Mitchell $(2000,2019)$. However, contrary to previous expectations, recent work has shown that the Transition Province Plenus Marls - Melbourn Rock facies seen at Trunch continues and expands offshore 
north Norfolk, with $\geq 2$ m of Plenus Marls observed in cores and seismic profiles (Mortimore and James, 2015; Fig. 1).

\subsubsection{Cenomanian - Turonian boundary (CTB)}

The base of the Turonian is placed at the surface of the planar hardground at 500.07 $\mathrm{m}$, evidenced by the appearance of abundant Mytiloides spp. inoceramid bivalves in the overlying shelly chalks (Wood et al., 1994; cf. Kennedy et al., 2005; Fig. 3). The chalk below this, between the convolute hardground at $500.51 \mathrm{~m}$ and the planar hardground, was assigned by Wood et al. (1994) on general stratigraphir grounds to the uppermost Upper Cenomanian Neocardioceras juddii Zone, but there is no hiostratigraphic evidence to support this interpretation.

Carbon isotope values attain a maximum for the r o a $r_{i} 3.6 \% \delta^{13} \mathrm{C}_{\text {carb }}$ at $499.8 \mathrm{~m}$, immediately above the planar hardground, the ch iks $^{2}$ one from which yields a value of $3.2 \%$ (Fig. 5). Compared to the CTB Chalk refer nc $^{2}$ section at Eastbourne and other Plenus Marls successions in southern Englan' ' 'Ja 'vis et al., 1988a, b, 2001, 2006, 2011; Jeans et al., 1991; Leary and Peryt, 1991', ' 'aı et al., 1993, 2005; Jenkyns et al., 1994; Lamolda et al., 1994; Paul et al., 1999; k. 'ler et al., 2001; Tsikos et al., 2004; Pearce et al., 2009) and the Black Band section :t South Ferriby in Yorkshire (Schlanger et al., 1987; Hart et al., 1991), these relai /e y low maximum carbon isotope values suggest that sediments representing $t h_{1}$ stage boundary interval (upper Metoicoceras geslinianum - Watinoceras '`vu.?ensis Zones), which typically yield values of $>4 \%$ o $\delta^{13} \mathrm{C}_{\text {carb }}$ (i.e. the interval thal $\ldots$..cludes CTBE peaks a - c of Jarvis et al., 2006, 2011), are absent at Trunch. It 1 . cu...-luded that a significant hiatus spanning the Cenomanian Turonian boundary o ars at the planar hardground surface. Our dinocyst study cannot contribute further to the stratigraphic analysis because all samples spanning the stage boundary (M.geslinianum to basal Mytiloides zones) proved to be barren of palynomorphs (Fig. 3, Supplementary Material Table 2).

\subsubsection{Turonian}

\section{Lower Turonian (500.07 - $496.0 \mathrm{~m})$}

A concentration of stylolites and thin marly partings from $495.9-496.0 \mathrm{~m}$ is interpreted to represent the Chalk Hill Marls (Fig. 3), which mark the boundary 
between flintless and overlying flinty portions of the Welton Chalk of the Northern Province (Wood and Smith, 1978; Gaunt et al., 1992; Wood, 1992; Wood et al., 1994; Mitchell, 2000). In the Trunch succession, and generally in the Northern Province (Mitchell, 2000), the marls coincide with a facies transition from grey gritty calcarenitic and nodular chalks rich in Mytiloides, below (with 'Melbourn Rock' facies at the base; Jukes-Browne, 1880; Hill and Jukes-Browne, 1886; Jukes-Browne and Hill, 1903; Jeans, 1980), to finer grained whiter less nodular chalks, above (Fig. 3). Mitchell (2000, 2019) referred the unit of calcarenitic chalks of the Lower Turonian to the Buckton Member, and the overlying flinty chalks to the Bempton Member. He placed the base of the Middle Turonian at the level of the first flint, immediately aho a the Chalk Hill Marls, albeit with little biostratigraphic control.

A well-defined minimum in the $\delta^{13} \mathrm{C}_{\text {carb }}$ profile at $1,75 \mathrm{~m}$ in the Trunch core (Fig. 5 ) is equated to the Lulworth CIE (=Tu5 of Voigt et. di. $\angle J 07)$ of the upper Lower Turonian (Jarvis et al., 2006). However, sampling re $\mathrm{e}_{\lrcorner}$lution is inadequate to identify the finer scale $\delta^{13} \mathrm{C}_{\text {carb }}$ isotope events of the $\mathrm{L}$ w/e Turonian (Tu1 - Tu4; Voigt et al., 2007; Jarvis et al., 2015).

\section{Middle Turonian (496.0 - 475.0 m)}

The record of a fragmentary ( ol «oniceras? at $495.40 \mathrm{~m}$ (Wood et al., 1994) is indicative of the Middle Turoniın ¿nllignoniceras woollgari (Mantell) - Mytiloides subhercynicus (Seitz) - Conulu subrotundatus Mantell association that characterises the basal New Pit Chalk in sou :her n England (Mortimore et al., 2001; base Middle Turonian C. woollgari Zone), and nar xs the base of the Middle Turonian in Germany (Ernst et al., 1983). The presence of larker grey semi-silicified nodules around this level (Fig. 3) may indicate a correlation with the First Main Flint of the Northern Province succession (Wood and Smith, 1978; Wood, 1992). The Lower - Middle Turonian boundary is provisionally placed at the Chalk Hill Marls.

The base of the Terebratulina lata Zone was placed at the thin $2 \mathrm{~mm}$ grey-green marl and a stylolitized surface at $493.97 \mathrm{~m}$ by Wood et al. (1994), although the lowest $T$. lata (R. Etheridge) was recorded much higher, at $489.32 \mathrm{~m}$, immediately above the Conulus bed and just below a facies change to marlier chalks (Fig. 3). However, Inoceramus ex gr. cuvieri (J. de C. Sowerby) - I. ex gr. lamarcki Parkinson first appear around $493.0 \mathrm{~m}$, indicating these beds lie within the T. lata Zone as recognised in the 
Southern Province (Mortimore et al., 2001). Terebratulina lata is recorded sporadically in the Welton Chalk elsewhere and is uncommon in the lower beds of its index zone (Rowe, 1904; Mitchell, 2019).

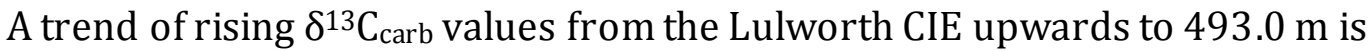
followed by sharply falling values above (Fig. 5). The break point in the isotope profile is equated to the low-woolgari CIE (Tu10) and an underlying single point peak at 495.0 $m$ to the Round Down CIE (Tu8), both prominent markers in the lower Middle Turonian (Voigt et al., 2007; Jarvis et al., 2015). The carbon isotope correlation to Dover (Jarvis et al., 2006) places the bottom of the T. lata Zone below the Round Down CIE, around the level of the Chalk Hill Marls (Fig. 3).

A succession of named marker marls typical of the No, the in Province Middle Turonian [(Wood and Smith, 1978; Whitham, 1991; Caı nt „t al., 1992; Sumbler, 1999; Mitchell, 2000, 2019; Rawson and Whitham, 2000'; L's 'Anglian named equivalents are indicated in parentheses (Woods et al., 2012)], and 1. shly characteristic of the Welton Chalk Formation, has been identified at Trun b (Wood et al., 1994; Fig. 3). These include beds that have been identified $50 \mathrm{e}_{\mathrm{L}}{ }^{2} \mathrm{~m}$ nites based on their geochemical signatures (Wray and Wood, 1998; Wrá, 1999; designated B1 - B5 in this paper). Middle - basal Upper Turonian markıns (Fig. 3) are the: (1) Grasby Marl (Methwold Marl), a $2 \mathrm{~cm}$ grey-green laminated $\mathrm{n}$; rl with its base at $487.59 \mathrm{~m}$; (2) Barton Marls 1 4, the lowest of which (Barton : 'arl 1, Lower Marl; B1 bentonite) is a grey-green $1 \mathrm{~cm}$ laminated marl with chalk h nsıs and its base at $483.66 \mathrm{~m}$; Barton Marl 2 (Pilgrims' Walk Marl), a $5 \mathrm{~mm}$ grer sren laminated bed with irregular top and bottom stylolitized surfaces and its base - + a $2.71 \mathrm{~m}$; Barton Marls 3 - 4 constitute thin marly partings; (3) Melton Ross Marl (Mc …t Ephraim Marl; B2 bentonite), a prominent $8 \mathrm{~cm}$ greyish green marl with its base at $478.03 \mathrm{~m}$; (4) Riby Marl, a $1 \mathrm{~cm}$ grey-green laminated stylolitized marl with its base at 475.44 m; (5) Deepdale Lower Marl (Twin Marls; B3 bentonite), a 2 $\mathrm{cm}$ grey-green laminated marl with a relatively planar top, irregular stylolitic base at $471.72 \mathrm{~m}$, and enclosed lenses of chalk.

The declining $\delta^{13} \mathrm{C}_{\text {carb }}$ trend above the low-woolgari CIE changes to a plateau interval with erratic values at the facies change from nodular to marly chalks at $489.0 \mathrm{~m}$ up to 480.0 m (Fig. 3), above which the long-term decline resumes (Fig. 5). The peak and breakpoint at the top of the plateau interval can be confidently correlated to the 'Pewsey' CIE (Jarvis et al., 2006), but a lack of stratigraphic resolution and erratic values 
in the plateau interval make the identification of other CIEs uncertain. The Glynde negative CIE is placed at the level of Barton Marl 1 that correlates to Glynde Marl 1 of the Southern Province, the B1 bentonite (Figs 2 - 3).

\section{Upper Turonian (475.0 - $429.9 \mathrm{~m})$}

The base of the Upper Turonian in northern Europe is generally defined by the lowest occurrence (LO) of Subprionocyclus neptuni (Geinitz) (Bengtson, 1996; Ogg et al., 2004), which is approximately coincident with the LO Inoceramus perplexus Whitfield (= 'Inoceramus costellatus' as widely applied in Europe; Walaszczyk and Wood, 1998). These index taxa have not been recorded at Trunch. These 1 . ' datum levels lie below the Southerham Marl 1 (B2 bentonite) in southern Englar d (G ale, 1996; Jarvis et al., 2006) and its correlative, the Melton Ross Marl of the I ort ern Province (Mortimore et al., 2001), and are located between the Lower and I Ink ?r Southerham CIEs (Jarvis et al., 2006, 2015).

A long-term carbon isotope minimum ocr ur s between $478.0-480.0 \mathrm{~m}$ at Trunch (Fig. 5), within which there are a number c. ratner poorly resolved peaks and troughs. A marked negative excursion immedia oly above the Deepdale Lower Marl (=Caburn Marl equivalent; B3 bentonite) may he assigned to the Bridgewick CIE, and the immediately underlying positive $\mathrm{f} \mathrm{xr}_{\mathrm{u}}$ “ cion to the Caburn CIE (Cb in Fig. 3). The Lower and Upper Southerham CIEs ar \le is easily placed. Assuming the marl succession described above correctly ide. tifies the positions of the key marker marls, the Lower Southerham CIE should lit hel Jw the Melton Ross Marl at 478.03 m. A positive excursion is not see? hi re. The Upper Southerham CIE should lie between the Melton Ross and Deepdale Low'r Marls but is not well resolved. Higher resolution data are needed to address this problem but, in the meantime, the base of the Upper Turonian is provisionally placed above the Riby Marl, at $475.0 \mathrm{~m}$.

A $9 \mathrm{~cm}$ semitabular flint (Deepdale Flint) and Conulus horizon at $472.50 \mathrm{~m}$ is overlain by a $8 \mathrm{~cm}$ nodular flint at $472.25 \mathrm{~m}$ (Fig. 3; Wood et al., 1994). It is notable that these, together with a $6 \mathrm{~cm}$ nodular flint at $486.46 \mathrm{~m}$, are the only flints in the Welton Chalk at Trunch. This contrasts to the more generally flinty nature of the Formation in the Northern Province (Wood and Smith, 1978; Whitham, 1991; Gaunt et al., 1992; Mitchell, 2000, 2019; Mortimore et al., 2001), referred to the Bempton Member by Mitchell (2000). A horizon of stylolitic marly partings at $469.32 \mathrm{~m}$ corresponds to the 
base of the Burnham Chalk Formation, characterised by a facies change from stylolitic, nodular and relatively massively bedded chalks of the Welton Formation, to marlier thin-bedded 'laminate' chalks with marl seams, and abundant tabular and semitabular flints in the Burnham Formation (Wood and Smith, 1978; Gaunt et al., 1992; Wood et al., 1994; Mitchell, 2019).

Notable fossil records in the higher Welton Chalk at Trunch include a bed with abundant Orbirhynchia, inoceramids and Terebratulina below $480.75 \mathrm{~m}$, and a bed with "Offaster sphaericus" (Morter et al., 1975), common inoceramids, Terebratulina and Orbirhynchia at $476.60 \mathrm{~m}$. The Welton Chalk at Trunch proved to be almost entirely barren of palynomorphs (Fig. 3, Supplementary Material 'ra'le 2), but these reappear in abundance at the base of the Burnham Chalk and are nr se it in all samples studied above.

The basal beds of the Burnham Chalk in the Nr ri. eı $\mathrm{n}$ Province contain a succession of named tabular and semitabular flints and marls ( $v$ ' ood and Smith, 1978; Whitham, 1991; Mitchell, 2019) that can be recognised Ravensdale Flint, a $9 \mathrm{~cm}$ semitabular at $\mathrm{r}^{-} 9 . \mathrm{c}^{2} \mathrm{~m}$ with a $2 \mathrm{~cm}$ pseudobreccia marl $50 \mathrm{~cm}$ above that is normally silicified and loci. $v$ fused to the top of the flint in northern England; (2) Triple Tabular Flints (Ru ' gh and Smooth Black flints, in part), a $10 \mathrm{~cm}$ tabular at $466.37 \mathrm{~m}, 14 \mathrm{~cm}$ tabula $: \mathrm{t}: 65.47 \mathrm{~m}$, and a $5 \mathrm{~cm}$ semitabular at 464.97, with common P. (S.) plana above; (3), North Ormsby Marl (Grimes Grave Marl), a 4 cm greygreen laminated marl with is bise at $462.74 \mathrm{~m}$, overlain by fossiliferous chalks yielding oysters, inoceramids, br - hic pods and echinoderms, and considered to represent the B4 bentonite; (4) Lucho a agh Flint (Floorstone Flint) a $30 \mathrm{~cm}$ tabular flint with its base at $460.30 \mathrm{~m}$. The last $\_$chese is one on the most prominent marker beds in the Northern Province Chalk ('the white flint' of Rowe, 1929; Wood and Smith, 1978; Wood et al., 1994).

The Ravensdale Flint to Ludborough Flint succession represents a 'Northern Province Flint Maximum' (Fig. 3), that is equivalent to the 'Brandon Flint Series' in the Transitional Province of central and southern East Anglia (Skertchly, 1879; Hewitt, 1935; Mortimore and Wood, 1986; Bristow, 1990; Hildreth, 2019). The latter was mined extensively in prehistoric times for the production of flint tools and subsequently for gun flints, continuing into the mid-20 th century (Clark and Piggott, 1933; Clarke, 1935). Other notable features in this interval (Fig. 3) are: a $2 \mathrm{~cm}$ medium grey marl 
with associated chalk pebble 'pseudobreccia' at $468.35 \mathrm{~m}$, overlain by echinoid-rich chalks at $468.28 \mathrm{~m}$; beds yielding abundant Infulaster from $468.30-467.00 \mathrm{~m}$; a band of Plesiocorys (Sternotaxis) plana (Mantell) at $464.82-464.70 \mathrm{~m}$. Omission surfaces, with cemented nodular chalks below, occur at 463.82, 461.23 and $460.90 \mathrm{~m}$.

The next major regional marker bed recognised in the succession is the Ulceby Marl (West Tofts Marl), a $5 \mathrm{~cm}$ grey-green crinoidal marl with its base at 442.81, overlain at 442.00 - $441.50 \mathrm{~m}$ by the Ulceby Oyster Bed (Fig. 3), with common pycnodonteine oysters, Plesiocorys, brachiopods and other fossils (Gallois and Morter, 1976). The abundance of small crinoid columnals in the Ulceby Marl makes this bed particularity distinctive (Wood and Smith, 1978; Gaunt et al., 1992). This sunports its correlation to the Lewes Marl of the Southern Province (Fig. 2) that is als ? $r$ in in crinoid debris and is interpreted as bentonite B5 (Wray and Wood, 1998). b tw een the Ludborough Flint and the Ulceby Marl are a pair of $2-3 \mathrm{~cm}$ marls w' il their bases at 459.57 and 458.90 m (Fig. 3), the grey-brown colour of the lower marl, inntrasting to the grey-green colour of the upper marl. The brown colour : $u_{j} g$ sts that the former is equivalent to the Thornton Curtis Marl of the Northe „ Dru vince (Wood and Smith, 1978). A $2 \mathrm{~cm}$ grey-green laminated marl at $453.93 \mathrm{~m}$ : zely correlates to Wootton Marl 2, the more persistent of a marl pair elsewhere in the Northern Province. The flinty chalks between the Thornton Curtis Marl and Wout 011 Marl 2 contain a number of marly intervals and omission surfaces (Fig. 3).

Between Wootton Marl? a.d the Ulceby Marl there is a complex of nodular chalks and hardgrounds overla in $\mathrm{b}$; d succession of well-developed semitabular and tabular flints (Fig. 3). This in 'ar is correlative to the 'Vale House Flints Member' of the Northern Province (H:-ireth, 2013; Green, 2019), although the hardground complex at Trunch equates to a flinty chalk succession lacking hardgrounds in Lincolnshire and east Yorkshire. No hardgrounds have been identified in the Burnham Chalk of the Northern Province (Gaunt et al., 1992), but a hardground succession comparable to that at Trunch continues in the Transitional Province facies developed offshore north Norfolk (Mortimore and James, 2015 fig. 11).

Two major hardgrounds occur in the Vale House Flints Member equivalent interval at Trunch, the lower with a convolute surface at $452.19 \mathrm{~m}$, and the upper, better cemented hardground, with a pinkish ?phosphatised surface at $449.89 \mathrm{~m}$ (Gallois and Morter, 1976). The convolute hardground consists of fossiliferous yellow-stained chalk 
with prominent marl-filled Thalassinoides burrows, and represents the top of a closely spaced flinty hardground complex with a second planar surface below, at $452.42 \mathrm{~m}$, and three further cemented omission surfaces at 452.65, 452.90, $453.10 \mathrm{~m}$ (Fig. 3). An additional minor hardground surface occurs above the convolute hardground, at 451.70 $\mathrm{m}$. The hardground at $449.89 \mathrm{~m}$ is the strongest developed in the Vale House Flints Member interval. It displays variegated mineralisation, pebble - cobble chalk intraclasts, grey chalk filled T. paradoxica burrows, and abundant dark grey sponge remains, bivalves, and brachiopods (Gallois and Morter, 1976). The 'laminate' chalks between the two main hardground intervals are highly fossiliferous with inoceramids, brachiopods, oysters, bryozoans, crinoids and echinoids. The : ardground succession was referred to the 'Chalk Rock' by Gallois and Morter (19?6)

The Chalk Rock hardground succession at Trunck cin _ides with a well-defined medium-term maximum and peak in the $\delta^{13} \mathrm{C}_{\text {carb }} \mathrm{p} \mathrm{or}^{1} \mathrm{e}$ chat is assigned to the Hitch Wood CIE (Fig. 5), one of the most clearly defined ew nts in the Upper Cretaceous carbonate carbon isotope chemostratigraphy ('sa'e, 1996; Jarvis et al., 2006, 2015). This CIE lies within the lower Upper Tu . via. P. (S.) plana echinoid Zone (midSubprionocyclus neptuni ammonite Zont, immediately above the Hyphantoceras faunal Event. The 'Hyphantoceras Event' re r esents an important stratigraphic marker in the Upper Turonian of Western Europe ( $/$ / iese et al., 2004; Jarvis et al., 2015), being widely recognized in southern Englani' northern Spain, parts of France, Germany, the Czech Republic, Poland, and Kazah' 'su.n, and potentially northern Algeria (Kaplan and Kennedy, 1996).

It is likely that th. $s_{2}$.ngly developed mineralised hardground at the top of the Chalk Rock beds at Tr....ch (Fig. 3) equates to the Hitch Wood Hardground of the main Transitional Province Chalk Rock Member succession (Bromley and Gale, 1982; Gale, 1996; Mortimore et al., 2001). This hardground is known for its preservation of an aragonitic molluscan 'reussianum fauna' (Woods, 1896; Wright, 1979), characterised by the presence of the heteromorph ammonite Hyphantoceras (Hyphantoceras) reussianum (d'Orbigny). A reussianum fauna has not been recorded at Trunch, but the sediments above the Hitch Wood Hardground are gritty and calcarenitic at their base and are very fossiliferous, with brachiopods, bryozoans, inoceramids and echinoid debris being particularly abundant. This interval been referred to as the 'Santon Downham Fossil Bed' (Gallois and Morter, 1976; Hildreth, 2013). An equivalent level above the Chalk 
Rock at Mundford, southern Norfolk, has yielded an abundant 'reussianum fauna' (Gallois, 2016), also documented around Santon Downham, north Suffolk (Hewitt, 1924), $6 \mathrm{~km}$ to the south of Mundford. However, specimens of $H$. (H.) reussianum have also been recorded from just below and above the Wootton Marls in the Northern Province (Mortimore and Wood, 1986; Whitham, 1991; Gaunt et al., 1992; Green, 2019), which would place the onset of the Hyphantoceras Event before the $\delta^{13} \mathrm{C}_{\text {carb }}$ maximum of the Hitch Wood CIE, as seen elsewhere in England and mainland Europe (Jarvis et al., 2015).

The higher beds of the Vale House Flints Member, up to the Ulceby Marl (B5 bentonite) at $442.81 \mathrm{~m}$, consist of a succession of marly chalks -ontaining two prominent tabular and one nodular flint (Fig. 3), and inclu ' ' - ' 'fossil bed' rich in bryozoans, serpulids, small brachiopods and inocerar a. ${ }^{3} \mathrm{c}-\mathrm{c} 444.00-443.75 \mathrm{~m}$ (Gallois and Morter, 1976). A minor positive $\delta^{13} \mathrm{C}_{\text {carb }}$ excur slu 1 at $447 \mathrm{~m}$ is correlated to the i1 peak of Jarvis et al. (2006). This was termed Hitcr v rod 2 (HW2) by Jarvis et al. (2015) to reflect differences in the carbonate carbon a 10 organic carbon isotope profiles around the Hitch Wood CIE documente i i ? li. Bohemian Cretaceous Basin (Uličný et al., 2014; Jarvis et al., 2015). There, higı, resolution paired carbon-isotope curves from the Běchary Bch-1 borehole show an affset in the position of the Upper Turonian $\delta^{13} \mathrm{C}$ maxima. For $\delta^{13} \mathrm{C}_{\text {carb }}$ this is situated in Imediately above the Hyphantoceras Event at the level of the Hitch Wood (HW1; ᄀIE, out maximum values for $\delta^{13} \mathrm{C}_{\text {org }}$ occur $20 \mathrm{~m}$ higher at the level of HW2 (base M. sc:'pı. i Zone; Jarvis et al., 2015 fig. 5).

The succession up $\operatorname{tr} \wedge \ldots$ above the Ulceby Marl consists of flinty, marly and shelly chalks containing nut. $\ominus_{1}:$ is omission surfaces, nodular chalks and thin hardgrounds. This facies contrasts t 'ne more massive white chalks with abundant nodular, semitabular and tabular flints that characterise the equivalent interval in the Northern Province (Gaunt et al., 1992; Mitchell, 2019), which prevents the recognition of the key named marker beds that define the stratigraphy in that region. Of note at Trunch are a $50 \mathrm{~cm}$ fossiliferous bed with its base at 442.00 m yielding Pycnodonte oysters, correlated to the Ulceby Oyster Bed (Wood et al., 1994). A positive $\delta^{13} \mathrm{C}_{\text {carb }}$ excursion spanning the Ulceby Marl and Ulceby Oyster Bed interval (Fig. 3) corresponds to the i2 peak of Jarvis et al. (2006), termed Hitch Wood 3 (HW3) by Uličný et al. (2014) and Jarvis et al. (2015). 
Beds yielding Pycnodonte occur at 440.05 - 439.90, and above a hardground surface at $439.05 \mathrm{~m}$. A band of common Plesiocorys occurs at $435.10-434.52 \mathrm{~m}$.

\subsubsection{Turonian - Coniacian boundary}

A prominent pink variegated mineralised convolute hardground surface with yellow sponge-rich nodular chalks below, cut by dark grey to black marly chalk filled Thalassinoides, Planolites and Zoophycos burrows, is developed at $432.03 \mathrm{~m}$. Small Cremnoceramus waltersdorfensis waltersdorfensis (Andert) and Cremnoceramus rotundatus (Fiege) occur with Didymotis sp. in the chalk immediately above the hardground between 431 and $432 \mathrm{~m}$ (Fig. 3), and Inoceramus? rostellatus Woods is recorded at $435.5 \mathrm{~m}$ (Wood et al., 1994). These faunal rec. $r d$, demonstrate that the sediments immediately above the hardground are to nn ast Upper Turonian $C$. waltersdorfensis inoceramid Zone (lowest Forreste, in 'riarleites) petrocoriensis ammonite Zone), and correlate to the Navigation Haı tgrounds and Navigation Marls complex of the Southern Province (Bailey et : l. 1 )84; Mortimore, 1986; Wood et al., 1994; Mortimore et al., 2001), and bro u.r tu the Top Rock of the Transitional Province in Suffolk (Bristow, 1990; Woods et al., ¿ 112; Gallois, 2016). The surface of the Navigation Hardground at $432.03 \mathrm{~m}$ is taken to mark the top of the $P$. (S.) plana Zone. Nodular chalks and hardground $a_{1} \epsilon$ al Isent from equivalent Northern Province successions; there, the inocera. 'id-Didymotis association occurs $0.15 \mathrm{~m}$ beneath the middle of the three Kiplingcites Marls (Gaunt et al., 1992), the highest of which is represented at Trunch $r_{j}+h_{1}=$ marl seam at $430.15 \mathrm{~m}$ (Wood et al., 1994).

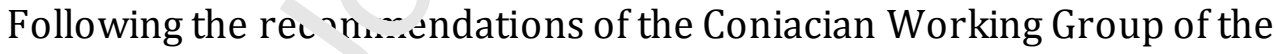
Subcommission on Cr ${ }^{+}{ }_{4}$ ceous Stratigraphy (Kauffman et al., 1996; Walaszczyk and Wood, 1998), the base of the Coniacian is placed at the lowest occurrence (LO) of Cremnoceramus deformis erectus (Meek), previously referred to Cremnoceramus rotundatus (sensu Tröger, non Fiege) (Walaszczyk et al., 2010; Ogg and Hinnov, 2012), which is coeval with the LO Scaphites preventricosus Cobban in the US Western Interior Basin (Walaszczyk and Cobban, 2000; Cobban et al., 2006). Cremnoceramus d. erectus has not been identified at Trunch, but in addition to the uppermost Turonian $C . w$. waltersdorfensis - Didymotis association recorded from immediately above the Navigation Hardground, specimens of Cremnoceramus waltersdorfensis hannovrensis (Heinz) are common with Cremnoceramus rotundatus (Fiege) at 427.88, and large C.w. 
hannovrensis (Heinz) occur at 426.96 m (Fig. 3), indicative of the Lower Coniacian $C$. hannoverensis inoceramid Zone.

The LO of $C$. $d$. erectus in the candidate Coniacian stratotype section of Salzgitter-

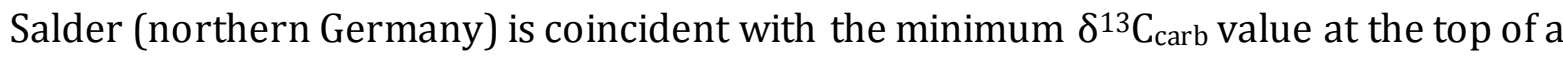
broader trough defining the Navigation CIE (Voigt and Hilbrecht, 1997; Walaszczyk and Wood, 1998; Jarvis et al., 2006, 2015; Walaszczyk et al., 2010). This is $\sim 1 \mathrm{~m}$ above the LO of C.w.waltersdorfensis and a flood of Didymotis (Didymotis Event II of Wood et al., 1984); the LO of C. w. hannovrensis occurs several metres higher in the section. An identical relationship between the isotope profile and the inoceramid-Didymotis succession is observed in sections in SE England and in the (.ze - $\mathrm{h}$ Republic (Jarvis et al., 2006, 2015; Uličný et al., 2014). A distinctive sharp $\delta^{13} \mathrm{C}_{r a r}$. $\mathrm{n}^{\mathrm{n}}$, ak immediately preceding the Navigation CIE, around $433 \mathrm{~m}$ at Trunch (Fig. 3), s s he arved in other northern European carbon-isotope profiles (Jarvis et al., 201. The Turonian - Coniacian boundary at Trunch is rlac $d$ at the $\delta^{13} \mathrm{C}_{\text {carb }}$ minimum at 429.9 m, immediately above Kiplingcote Mar’ 3.

\subsubsection{Coniacian}

\section{Lower Coniacian (429.9 - 411.6 As)}

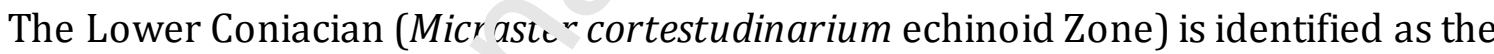
succession from $429.9 \mathrm{~m}$ to $\mathrm{a}_{1}$ interval of core loss at $411.63 \mathrm{~m}$, which was considered by Wood et al. (1994) to ru ${ }_{2} r f$ sent the position of a marl seam equivalent to the East Cliff Marl 2 / Shorel an. Ma 12 of the Southern Province, at the base of the Micraster coranguinum Zone (Fig. 2). This interpretation for the placement of the base of the Middle Coniacian is supported by records of Cremnoceramus crassus crassus Petrascheck (C. schloenbachi (Böhm) of earlier literature; Walaszczyk and Wood, 1998) around $420 \mathrm{~m}$, indicative of the mid-Lower Coniacian C.c. crassus Zone (Walaszczyk, 2000; Walaszczyk and, Wood 2018), and of Volviceramus koeneni (Müller), the basal Middle Coniacian marker ( $V$. koeneni Zone), at $406.78 \mathrm{~m}$. Volviceramus koeneni is restricted to a few metres of section between Shoreham Marl 1 and Belle Tout 1 Lower Marl in southern England (Mortimore et al., 2001), and occurs at a similar position above the Little Weighton Marls, in the low Lower Hagenowia rostrata Zone of the Northern Province (Whitham, 1991). 
The succession of marly chalks, nodular chalks and hardgrounds with abundant nodular, semitabular and tabular flints that characterise the Lower Coniacian at Trunch differs from the typical lithological successions of both the Southern and Northern Provinces, and individual beds cannot be correlated to other areas with any confidence. Notable features include thick 13 - $14 \mathrm{~cm}$ semitabular - tabular flints at 427.06, 425.76 and $422.68 \mathrm{~m}$, a $3 \mathrm{~cm}$ grey-green laminated marl with a sharp top and irregular base containing small inoceramid chips and chalk pebbles at $423.00 \mathrm{~m}$, and a series of yellow nodular chalks and weak hardgrounds, including two with well-developed surfaces at 423.82 and $420.26 \mathrm{~m}$ (Fig. 3).

The bed yielding common Cremnoceramus at $427.88 \mathrm{~m} \mathrm{lik}^{\prime} \mathrm{v}$ marks the position of the C.w. hannovrensis Event recognized in northern Germanv (Walaszczyk et al., 2010). A record of $C$. w. hannovrensis within an interval of nc d. lar chalks at 426.96 m coincides with positive excursion in the $\delta^{13} \mathrm{C}_{\text {carb }}$ profile that $\mathrm{i}, \mathrm{c}$ r r elated to the Beeding CIE (Figs 3, 5). An increased in $\delta^{13} \mathrm{C}_{\text {carb values at }} 420.0 \mathrm{~m}$ in a $\mathrm{L}^{\text {ad }}$ yielding $C$. crassus crassus, immediately above a pair of hardgrounds (Li r c i loint Hardgrounds?) is indicative of the mid-Lower Coniacian C. c. crassus $\mathrm{Z}, 1$ ? a d the identification of the positive isotope excursion as the Light Point CIE.

\section{Middle Coniacian (411.6 - 378.0 I ?}

Beds of yellow-stained nodula chalk continue through the Middle Coniacian up to $402.70 \mathrm{~m}$. The record of $V$. kuneni at $406.78 \mathrm{~m}$ occurs at the base of a significant shift in the medium-term $\delta^{13} \mathrm{C}_{\mathrm{ca}} \cdot \mathrm{p}$ ' ofile, from relatively constant values above the Light Point CIE to sharply inc eas ing values between $408.0-406.0 \mathrm{~m}$. This can be confidently identified as the East Cli f CIE, which not only has a distinctive isotope signature but coincides elsewhere to an acme of $V$. koeneni (Jarvis et al., 2006).

Volviceramus aff. involutus (J. de C. Sowerby) is recorded at $402.62 \mathrm{~m}$, and Platyceramus mantelli (Barrois) at $401.65 \mathrm{~m}$ (Wood et al., 1994; Fig. 3). These taxa are typical of the Volviceramus-rich beds that characterise the basal M. coranguinum Zone (mid- to upper Middle Coniacian) in the Southern Province (Mortimore et al., 2001), and the basal part of the lower H. rostrata Zone in the Northern Province (Whitham,1991); V. involutus is the index species of the upper Middle Coniacian V. involutus Zone. A further shift in the medium-term $\delta^{13} \mathrm{C}_{\text {carb }}$ profile occurs at $401.0 \mathrm{~m}$, from rising values below, to a plateau with considerable short-term variation above. The peak developed 
at the base of this change of trend is assigned to the White Fall CIE, which coincides with the LO V. involutus elsewhere (Jarvis et al., 2006).

Wood et al. (1994) suggested that a prominent $9 \mathrm{~cm}$ tabular flint at $400.00 \mathrm{~m}$ is equivalent to the East Cliff Semitabular (Gale and Smith, 1982) and Seven Sisters Flint (Mortimore, 1986) of the Southern Province. This is not consistent with the carbon isotope correlation (Jarvis et al., 2006). However, a $9 \mathrm{~cm}$ massive nodular flint at 391.41 $\mathrm{m}$ in the Trunch core overlies a bed of $V$. involutus at $392.05 \mathrm{~m}$ and an oyster bed at 392.32 m (Fig. 3). Beds of $V$. involutus characteristically underlie the East Cliff Semitabular Flint in Kent (Bailey et al., 1984; Robinson, 1986), the Seven Sisters Flint in Sussex (Mortimore, 1986; Mortimore et al., 2001), and the F.p.' 'eworth Flint in the Northern Province (Wood and Smith, 1978; Whitham, 195, · r aunt et al., 1992), indicating the equivalence of these regional marker $b \mathrm{c}^{-\mathrm{t}}{ }^{\mathrm{t}} \mathrm{r}$ the identified Trunch flint.

An interval of poor core recovery between $39 \% . .2$ and 396.86 m includes a massive $8 \mathrm{~cm}$ flint, and Gallois and Morter (1976) indicater! t $\mathrm{t}_{1}{ }^{2}$ presence of a marl around $395 \mathrm{~m}$ based on their interpretation of the geophysi $s \quad f 19$ m thick succession of fossiliferous flinty white chalks with occasional inter ${ }_{v e}{ }^{\prime} s$ 'isplaying stylolitic marly partings characterise the succession above the Ea t Cliff Flint at Trunch (Fig. 3).

\section{Upper Coniacian (378.0 - 372.5 «)}

The base of the Upper Coni $x_{\mathrm{Cla}} \mathrm{n}$ is very poorly constrained in England. The substage boundary is definea $: v$ the LO of the inoceramid bivalve Magadiceramus subquadratus (Schlüter) (1 vut tman et al., 1996; Ogg and Hinnov, 2012), and is marked also by the appeara:se of c mmon sphenoceramids (Walaszczyk and Wood, 2018), including Sphenoceramu; subcardissoides (Schlüter). No definitive Upper Coniacian fossil markers have been identified at Trunch, and equivalent strata throughout the Southern and Northern Provinces are also poorly dated ('barren beds' of Mortimore et al., 2001). A number of peaks and troughs characterise the $\delta^{13} \mathrm{C}_{\text {carb }}$ plateau interval of the Middle - Upper Coniacian (e.g. Fig. 5) but the unambiguous correlation of these is hampered by the low sampling resolution of published carbon isotope curves. Nonetheless, a weakly defined $\delta^{13} \mathrm{C}$ maximum in the middle of the plateau interval, in the assumed Middle Coniacian, was designated as the Kingsdown CIE by Jarvis et al. (2006). 
The base of the Upper Coniacian in the Southern Province is somewhat arbitrarily placed at the base of the 'barren beds', a short distance below the Cuckmere Sponge Bed (Mortimore et al., 2001). Higher resolution $\delta^{13} \mathrm{C}_{\text {carb }}$ data for the Coniacian of Seaford Head, East Sussex indicate that this corresponds to the bottom of an unnamed positive isotope excursion that occurs above the peak defining the Kingsdown CIE (Thibault et al., 2016). Correlation to Trunch places the equivalent level at approximately $378 \mathrm{~m}$ depth.

\subsubsection{Coniacian - Santonian boundary}

The base of the Santonian stage (Lamolda et al., 2014) is a (fined by the lowest occurrence (LO) of Cladoceramus (Platyceramus) undulatc ${ }_{\mathbf{r}}$ lir stus (Roemer). A possible C. undulatoplicatus was recorded by Wood et al. (1991, गt $565.80 \mathrm{~m}$ at Trunch, just above a $9 \mathrm{~cm}$ flint at $366.50 \mathrm{~m}$ (Fig. 4). Cladocerar «us 'иıdulatoplicatus occurs in flood abundance at two levels in the basal Santonian (B ille.r et al., 1984; Lamolda et al., 2014), the upper and most prolific of which c i.tc des with the Bedwell's Columnar Flint (Bedwell, 1874; Rowe, 1900) in southe "1 ' . $_{6}^{-l}$ and (Bailey et al., 1983, 1984; Mortimore, 1986; Mortimore et al., 2001).

The correspondence between Clu doceramus records and carbon isotope stratigraphy has been considered $s$ a number of authors (Jarvis et al., 2006; Gale et al., 2007; Paul and Lamolda, 2009, ' amolda et al., 2014; Thibault et al., 2016). A series of low amplitude peaks and trugis occur superimposed on a trend of long-term upwardsfalling $\delta^{13} \mathrm{C}_{\text {carb }}$ values by $\quad$ (.- $\%$ between the Middle Coniacian Kingsdown positive CIE and the Middle Santu. ia. $_{\text {. }}{ }^{13} \mathrm{C}_{\text {carb }}$ minimum and Haven Brow negative CIE (Fig. 5). Small $\delta^{13} \mathrm{C}_{\text {carb }}$ peaks o $-\mathrm{ur}$ around the levels of both the lower and the upper $C$. undulatoplicatus bands - the Michel Dean and Bedwell CIEs, respectively (Jarvis et al., 2006).

Biostratigraphic and $\delta^{13} \mathrm{C}_{\mathrm{carb}}$ chemostratigraphic correlation of SE England sections with Ten Mile Creek, Texas and the Santonian GSSP at Olazagutia, Spain (Paul and Lamolda, 2009) confirms that the $C$. undulatoplicatus record at Trunch corresponds best to the Bedwell CIE. Consequently, the Coniacian - Santonian boundary is placed lower, at $372.5 \mathrm{~m}$, at the bottom of a marked $0.3 \% \delta^{13} \mathrm{C}_{\text {carb }}$ peak (Figs $4-5$ ). This implies that the $40 \mathrm{~cm}$ nodular flint at $372.60 \mathrm{~m}$, a short distance above a 'Middleton' sponge bed (cf. 
Wright and Wright, 1942; Gallois and Morter, 1976) at $373.10 \mathrm{~m}$, corresponds to the Michel Dean Flint (Mortimore, 1986) of southern England.

\subsubsection{Santonian}

\section{Lower Santonian (372.5 - $359.0 \mathrm{~m})$}

Regularly spaced large nodular and semitabular flints continue upwards through the Trunch succession from Bedwell's Columnar Flint to $350.61 \mathrm{~m}$, above which there is a notable decrease in the abundance and thickness of flint bands (Fig. 4). This is taken to mark the top of the Burnham Chalk Formation.

The Santonian - Lower Campanian of the Northern Pı ovir ce consists of flint-free chalks of the Flamborough Formation (Wood and Smit 1, 1: 78; Mitchell, 2019), which is characterised not only by the absence of flint (rare lar pale-coloured masses of chert occur in some sections; Mitchell, 1995), but also by th - presence of numerous marl seams spaced at approximately 1-m intervals (v hitham, 1993). The base of the formation is located immediately above the hignest significant flint (High Stacks Flint; Whitham, 1991) in the onshore North, rr. Province succession (top Burnham Chalk), and represents a sharp lithostratigi nhic boundary. It falls within the mid Cordiceramus cordiformis Zone in hr. :"iddle Santonian (Mortimore et al., 2001). The Flamborough Formation canns t bc zpplied as a lithostratigraphic unit in the Trunch succession.

The equivalent interva' in the Southern Province is represented by the Seaford Chalk (below) and I'ou hav ın Chalk (above) formations (Rawson et al., 2001; Fig. 2). The former consists of $p$ ire soft white chalks with conspicuous bands of large flint, the latter by firm marly chalks with numerous marls seams and regular but fewer flint bands; in parts of east Kent (Thanet), the Seaford Chalk is overlain by very soft, nearly flint-free chalk of the Margate Chalk Formation (Mortimore and Wood, 1986; Bristow et al., 1997; Mortimore et al., 2001). The base of the Newhaven Chalk is Buckle Marl1, which coincides with the base of the Upper Santonian Uintacrinus socialis crinoid Zone. A comparable lithological succession is not developed at Trunch, so the Southern Province lithostratigraphy cannot be used for the core.

Recognising the atypical character of the Trunch succession, we apply the term "Flamborough Chalk equivalent" to the upper part of our study section (Fig. 4). The 
base of the formation is placed at the top of the last major consistent flint in the succession at $350.61 \mathrm{~m}$, although this is some degree arbitrary since nodular flints remain common up to the core gap at $345.21 \mathrm{~m}$. The chosen boundary is some distance above a transition to marlier chalks from around $362 \mathrm{~m}$, expressed by an increase in aluminium oxide $\left(\mathrm{Al}_{2} \mathrm{O}_{3}\right)$ and falling calcium carbonate $\left(\mathrm{CaCO}_{3}\right)$ contents (Supplementary Material Table 1), and by total insoluble residues that rise from $\sim 1$ to $>2$ wt\% (Bath and Edmunds, 1981). Lower purity chalks characterise the remainder of the Santonian, but carbonate contents increase again from the base of the Campanian.

\section{Middle Santonian (359.0 - $336.8 \mathrm{~m})$}

The stratigraphic extent of the Lower Santonian, defir ad $\mathrm{k} y$ the total range of $C$. undulatoplicatus (Lamolda and Hancock, 1996), canno be letermined at Trunch due to a lack of adequate faunal records. Cordiceramus corn, , rmis (J. de C. Sowerby), a guide to the base of the Middle Santonian, is recorded at ${ }^{5} 5.98 \mathrm{~m}$. The $\delta^{13} \mathrm{C}_{\mathrm{carb}}$ minimum marking the low Middle Santonian Haven Bre w JIE occur immediately above at 354.0 m. The occurrence of Conulus at $354.01 \mathrm{~m}$ ind sphenoceramus ex gr. pachti (Arkhangelsky) - cardissoides (Goldfu ${ }^{-1}$ ^ t 352.33 and 353.54 m confirm a Santonian age.

Throughout southern Englan $t^{\prime} \lll$ base of the Middle Santonian lies approximately mid-way between the Bedwell inc Yaven Brow CIEs, between two small $\delta^{13} \mathrm{C}_{\text {carb }}$ peaks informally designated 11 and I? by Jarvis et al. (2006). Correlation of the Trunch carbon isotope profile (Fig. 5) to Los z elsewhere (Jarvis et al., 2006; Thibault et al., 2016) places the base Mid "le . an' Jnian at approximately $359 \mathrm{~m}$ in the core, around the facies change to marlier chalks (Fig. 4). A prominent $5 \mathrm{~cm}$ thick flint at $352.50 \mathrm{~m}$ has been correlated to Whitaker's 3-inch Flint based on the carbon-isotope stratigraphy (Jarvis et al., 2006).

Carbon isotope values increase upwards from the Haven Brow CIE and reach a maximum in the last sample immediately below a coring gap from $345.21-342.34 \mathrm{~m}$, above which a medium-term $\delta^{13} \mathrm{C}_{\text {carb }}$ fall is recorded. This $\delta^{13} \mathrm{C}_{\text {carb }}$ maximum, which is not fully resolved at Trunch due to the missing section, can be ascribed to the Horseshoe Bay CIE, a prominent high Middle Santonian marker in the Upper Cretaceous carbon-isotope stratigraphy (Jarvis et al., 2006; Thibault et al., 2016). 


\section{Upper Santonian (336.8 - $306.72 \mathrm{~m})$}

The lowest definite record of Uintacrinus socialis Grinnel, marking the base of the Upper Santonian (Lamolda and Hancock, 1996), is at 335.26 m, above a stylolitic marly plexus at $335.56 \mathrm{~m}$ (Fig. 4), and the index species is common in the overlying $10 \mathrm{~m}$ of section. The marly plexus coincides with a well-defined minimum in the carbon isotope profile indicative of the basal Upper Santonian Buckle CIE that is a prominent feature of northern European and Tethys isotope records (Jarvis et al., 2006; Thibault et al., 2016). A previously unidentified crinoid brachial at $336.8 \mathrm{~m}$ (Wood et al., 1994) is interpreted to be $U$. socialis since this level coincides with the base of th which lies in the lowest $U$. socialis Zone elsewhere (Jarvis $r_{i-1}{ }^{\prime}$, 2006; Thibault et al., 2016).

The marly plexus at $335.56 \mathrm{~m}$ is correlated to the Bunve Marls, which correspond to the base of the $U$. socialis Zone in the Southern I rov nce (Mortimore et al., 2001), and match the position of the West Nook Marls in the Jor ':ern Province (Mitchell, 2019). A burrow flint at $339.77 \mathrm{~m}$ may be an equival $\sim_{1}{ }^{2}$ of the Exceat Flint of southern England. A bed with oysters, inoceramids and er nin jde.m debris occurs above an omis sion surface at $330.15 \mathrm{~m}$. The highest definitiv Uintacrinus is recorded at $324.91 \mathrm{~m}$, although unidentified crinoid brachials nccur at 322.93 - 323.00 and $324.20 \mathrm{~m}$ (Wood et al., 1994). The lowest Marsurites, refining the uppermost Santonian Marsupites crinoid Zone (Hancock and Gi le, 1996), is recorded at 319.54 m (Wood et al., 1994).

The carbon isotope protı's aisplays long-term rising values from a minimum at the Buckle CIE to a maximu an it tne top of the Santonian (Fig. 5). Superimposed on the somewhat erratic risir $_{\varepsilon}$ trend of the low-resolution Trunch profile are a number of poorly resolved low-amplitude $\delta^{13} \mathrm{C}_{\text {carb }}$ peaks and troughs. Correlation to the southern England stratigraphy indicates that this corresponds to the Hawks Brow CIE (Jarvis et al., 2006; Thibault et al., 2016). A massive $8 \mathrm{~cm}$ burrow flint at $321.95 \mathrm{~m}, 2 \mathrm{~m}$ below the base of the Marsupites Zone, is correlated to the Hawks Brow Flint. A minor negative $\delta^{13} \mathrm{C}_{\mathrm{carb}}$ excursion at $316-315 \mathrm{~m}$ coincident with a marl seam at $314.96 \mathrm{~m}$ and a shift to rising $\delta^{13} \mathrm{C}_{\text {carb }}$ values above, corresponds in the stratigraphic position of the Foreness negative CIE and the Brighton 'Five' marls in southern England (Jarvis et al., 2006; Thibault et al., 2016).

The smooth ornamentation of the Marsupites plates recovered at $319.54 \mathrm{~m}$ are indicative of the species M. laevigatus Forbes that characterises the lower half of the 
Marsupites Zone (Gale et al., 2008). The highest Marsupites, with ornamented plates [= M.testudinarius (Schlotheim)], occurs at $307.35 \mathrm{~m}$. The LO of M. testudinarius occurs above the Brighton Marl in the Southern Province, a short distance above the Brighton 'Five' Marls (e.g. Thibault et al., 2016 fig. S1). Giant Porosphaera recovered at $306.80 \mathrm{~m}$ and $307.05 \mathrm{~m}$ are good secondary indicators of the Marsupites Zone.

\subsubsection{Santonian - Campanian boundary}

The highest occurrence of Marsupites has been proposed as the boundary marker for the base Campanian (Gale et al., 1995; Hancock and Gale, 1996; Gale et al., 2008), although a stage boundary definition and a GSSP remain to he coreed. Following Wood et al. (1994) and Jarvis et al. (2006), the base Campanian a: Tr unch is placed at the surface of the omission surface at $306.72 \mathrm{~m}$ which is $(\mathrm{v}, \mathrm{rl}=\mathrm{n}$ by shelly chalks with abundant inoceramid and oyster debris and comm Jin runioteuthis belemnites. Shelly chalks extend around 2 m below the omission surfac This lithological change is similar to that developed around the stage bc u.ı ary at Lägerdorf in northern Germany, the "Grobkreide” facies (Ernst, 1963; Sr'ac 'z ${ }^{+}+$al., 1984). The facies spans the uppermost Marsupites Zone to lower Go. ioteuthis granulataquadrata Zone (O. pillula Zone equivalent) in Yorkshire (Mitch`'l. 1995, 2019 fig. 12), and characterises the lower part of the Echinocorys scutata for on $d$ :pressula Subzone of the Offaster pillula Zone of southern England (Mortimore + al., 2001), and Northern Ireland (Creggan Chalk Formation, Ulster White Liı. asw ne Group; Fletcher, 1977; Hopson, 2005)

Placement of the sta $\mathrm{L}=$ undary at the omission surface is consistent with the

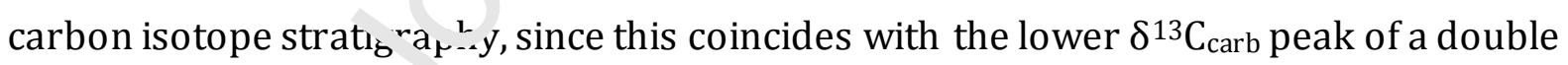
excursion spanning thi : stage boundary interval (Santonian - Campanian Boundary Event, SCBE; Jarvis et al., 2002, 2006; Thibault et al., 2016; Deville de Periere et al., 2019). It is possible that there is a non-sequence at the omission surface, since the sculpture of the Marsupites calyx plate at $307.35 \mathrm{~m}$ suggests a horizon below the top of the zone. A significant hiatus at this level has been described at Whitecliff, Isle of Wight, in southern England (Jarvis et al., 2006).

Uintacrinus anglicus Rasmussen, the index taxon of the U. anglicus Zone that underlies the Offaster pillula Zone in the lowest Campanian (Rawson et al., 1978; Bailey et al., 1983, 1984; Mitchell, 1994, 1995; Wood et al., 1994; Mortimore et al., 2001; Gale et al., 2008) has not been identified at Trunch, although the thickest known U. anglicus 
Zone in Europe is developed at Flamborough Head in Yorkshire (Mitchell, 1995, 2019; Deville de Periere et al., 2019). The relatively expanded nature of the positive $\delta^{13} C_{\text {carb }}$ excursion spanning the stage boundary at Trunch (cf. Jarvis et al., 2002, 2006; Thibault et al., 2016; Deville de Periere et al., 2019) suggests that sediments of this age are likely present.

\subsubsection{Campanian}

\section{Lower Campanian (pars; $306.72-270.00$ m)}

Campanian sediments consist predominantly of modera `ly lithified grey-white fossiliferous (inoceramids and calcitic bivalves, echinoids, crir oids, brachiopods, bryozoans, serpulids, belemnites, fish debris), locally c 'lcas enitic, chalk (Morter et al., 1975). Beds commonly display complex pale- and meı' 'um-grey marly fills of Zoophycos, Thalassinoides and Chondrites burrows. Tl in marly partings, some showing stylolitic textures, occur at some levels (Fig. ${ }^{4}$ ). Rlack centred, thalassinoid burrow flints and occasional thin secondary tabula. flints are present. Beds of pyritic blue-grey lithistid and hexactinellid sponge rema $n$, occur at many levels.

The lowest probable Offaster aı + Echinocorys scutata Leske form depressula Brydone, characterising the Lowe ' $\mathrm{C}_{\mathrm{a}}$ ?panian lower $O$. pillula Zone, are recorded in fossiliferous chalk at $296.94 \mathrm{~m}$ Mc rter et al., 1975). A prominent $6 \mathrm{~cm}$ laminated silty green-grey marl at $286.55 \mathrm{~m}_{1 \cdot}$ identified as the Wells Marl of the north Norfolk coast, correlative to the Old Nort Marl in southern England, and the M1 marl at Lägerdorf, northern Germany 'Nc ad , tal., 1994). This approximates to the boundary between the E. scutata depressula Sul zone and the overlying Abundant O. pillula Subzone (Brydone, $1912,1914)$. The subzone boundary is placed approximately $1 \mathrm{~m}$ below the marl at $287.78 \mathrm{~m}$, at the base of a bed yielding Offaster (Fig. 4). Records of Offaster pillula (Lamarck) at 284.51 and $283.68 \mathrm{~m}$, the latter overlaid by an inoceramid bed at 283.61 $\mathrm{m}$, probably represent the lower of two belts of $O$. pillula recognized in the Southern Province (Wood and Mortimore, 1988; Mortimore et al., 2001).

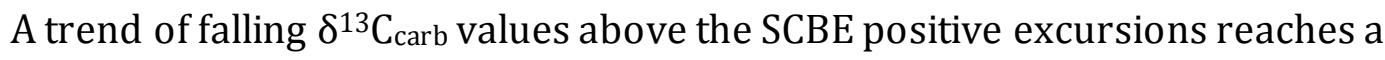
minimum immediately above the lower Offaster belt, above which a modest erratic rise occurs (Fig. 5). This carbon isotope minimum corresponds to the Pillula CIE, a 
prominent feature of the Lower Campanian isotope stratigraphy in Germany, England, Italy and Iran (Thibault et al., 2016; Razmjooei et al., 2018).

The highest occurrence of Hypoxytoma tenuiscostata (Roemer) at $279.91 \mathrm{~m}$ and Sphenoceramus at $275 \mathrm{~m}$ (Wood et al., 1994) are consistent with the Abundant O. pillula Subzone. A bed of medium-sized $O$. pillula in a burrowed marly interval between 272.5 - $273.5 \mathrm{~m}$ is inferred to be equivalent of the planoconvexus horizon with 0 . pillula form planatus Brydone that occurs at the top of the O. pillula Zone in southern England (Brydone, 1939; Mortimore et al., 2001). The base of the Gonioteuthis quadrata Zone is placed immediately above this horizon, at $272.50 \mathrm{~m}, 2.5 \mathrm{~m}$ helow the top of our study interval. A further $227 \mathrm{~m}$ of Campanian Belemnitella mucroncir and B. lanceolata Zone chalks are represented in the core, below an unconformity si', $\mathrm{n}$ Quaternary glacial deposits at $45.70 \mathrm{~m}$ depth (Gallois and Morter, 1976; $\mathcal{L}$ nor. et al., 1994; Voigt et al., 2012).

\section{$4 \quad$ Material and methods}

A total of 267 chalk samples were r'v רin $ר d$ from the BGS Keyworth core store, Nottingham, UK (https://www.bgs.ac.un, collections/corestore_kw.html). Chalk samples were taken at an average of : m spacing (Figs 3 - 4; Supplementary Material

Table 2); no flints (cherts) were cu! er ced. Higher resolution sampling was undertaken through the Cenomanian and $x_{2}$ ross the Turonian - Coniacian boundary due to the condensed nature of these $\mathrm{i}^{\text {'te }} \mathrm{r}_{\mathrm{r}}$ vals.

Core material availah $\mathrm{l}_{\mathrm{L}}$ =nsisted principally of chippings of $10 \mathrm{~cm}$ composite intervals. Sample $d_{r}{ }^{t h}{ }_{v}=$ e e thus reported to one decimal place; values represent the base of each $10 \mathrm{~cm}$ int $:$ val. Additionally, four samples were collected from specific marker horizons: 512.43 m, Hunstanton Formation (Red Chalk); 500.63 m, $M$. geslinianum Zone convolute hardground; 478.03 m, Melton Ross Marl (B2); 286.55 m, Wells Marl (Old Nore Marl equivalent). Where possible, $200 \mathrm{~g}$ of material was taken for palynological analysis, and an additional $50 \mathrm{~g}$ for elemental and stable-isotope geochemical analysis.

\subsection{Palynological methods}

All samples from the Trunch borehole were processed by Palynological Laboratory Services (PLS, Anglesey, UK) using a methodology based on the modified procedure of 
Batten and Morrison (1983) as described by Pearce et al. (2003). In summary, ca. $200 \mathrm{~g}$ (dry weight) of weighed disaggregated material, spiked with Lycopodium spore tablets, was treated with concentrated $(12 \mathrm{M}) \mathrm{HCl}$, concentrated $(29 \mathrm{M}) \mathrm{HF}$ and sieved with a 15 $\mu \mathrm{m}$ nylon sieve. Losses of dinocysts are known if a sieve size of greater than $15 \mu \mathrm{m}$ is used (Lignum et al., 2008, Mertens et al., 2009). Oxidation was not employed due to known problems with assemblage bias (Schrank, 1988; Dodsworth, 2000; Mertens, et al., 2009).

Where possible, 300 identified dinocysts (excluding pollen/spores, acritarchs and unidentified specimens) were recorded. A dinocyst specimen was recorded if over $50 \%$ of an individual was observed. Operculae and loisthocyst (rvsi- with no attached operculum; Sarjeant et al., 1987) fragments were recordec ho conly used to indicate the presence of a species if the loisthocyst was not includ 24 in he count. Although this procedure improves the description of the ass emb idy ${ }^{2} \mathrm{l}$ should be noted that not all operculae or loisthocyst fragments are diagnostic ^ ${ }_{0}^{0}$. necies level, and therefore, this procedure is not completely reliable. The sp c cies list and full taxonomic citations are provided in Appendix A. Counted abu' ‘' 'n '`s shown on the summary range chart (Fig. 6) are grouped into nine classes: presen hut outside of the main count ("+" $<1 / 300)$; rare $(1-4)$; frequent (5 - 9); very frt: (40 - 59); abundant (60 - 99); ver y ak undant (100 - 139); dominant (>139); reworked specimens are indicated (rw)

The calculation of abson te : bundances (palynomorphs per gram; ppg) follows Pearce et al. (2003). Val...s ... e reported with and without a correction for carbonate dilution (Pross et al. ¿nしこ; pearce et al., 2009); results are shown in Fig. 7. Values are reported below as the alk lithology abundance, with the carbonate-corrected values in parentheses (when available). Species richness (number of observed species) and the Shannon diversity index (H, calculated using PAST software, Hammer et al., 2001; https://folk.uio.no/ohammer/past/) are plotted in Fig. 7. Values are reported below as species richness, with the Shannon diversity in parentheses. Palynological count data are provided in Supplementary Material Table 2.

\subsection{Geochemical methods}

Stable isotope analysis $\left(\delta^{13} \mathrm{C}, \delta^{18} \mathrm{O}\right.$ of the carbonate phase) were undertaken at the stable isotope laboratory, Department of Earth Sciences, University of Oxford, UK. 
Subsamples of around $50 \mathrm{~g}$ were crushed to $<3 \mathrm{~mm}$ chips in clean thick-walled plastic bags, using a metal plate and hammer. The chips were hand ground to a fine powder in an agate pestle and mortar. Carbon and oxygen stable-isotope analyses of the bulk carbonate fraction $\left(\delta^{13} \mathrm{C}, \delta^{18} \mathrm{O}\right)$ in $250 \mu \mathrm{g}$ of powdered samples, using a VG Isogas Prism II mass spectrometer with an online VG Isocarb common acid bath preparation system. Samples were first cleaned using hydrogen peroxide and acetone and dried at $60^{\circ} \mathrm{C}$ for at least $30 \mathrm{~min}$. In the instrument they were reacted with purified phosphoric acid at $90^{\circ} \mathrm{C}$. Calibration to the Vienna Peedee belemnite (VPDB) standard via NBS-19 was made daily using the Oxford in-house (NOCZ) Carrara marble standard. Data are reported in delta $(\delta)$ notation as per mil (\%) relative to the $V_{1}$ 'DB standard (Fig. 5). Reproducibility of replicate standards was better than $0.1, n^{f}$ or $\delta^{13} \mathrm{C}$ and $\delta^{18} 0$. Trunch carbon-isotope data were plotted by Jarvis et al. (2005, nw nerical values were not provided); $\delta^{13} \mathrm{C}_{\text {carb }}$ and corresponding $\delta^{18} \mathrm{O}$ values al $\mathrm{rt}_{\mathrm{t}}$ ported for the first time here

\section{(Supplementary Material Table 1).}

For elemental analysis, samples were grc u ıả to fine powders in an agate ball mill, and dried at $60^{\circ} \mathrm{C}$; subsamples were fus $\mathrm{C}^{\prime} \mathrm{wi}^{\mathrm{h}} \mathrm{h} \mathrm{LiBO}_{2}$, and the melts dissolved in $0.5 \mathrm{M}$ $\mathrm{HNO}_{3}$ (Jarvis, 2003). Calcium determina 'ons were performed by inductively coupled plasma - atomic emission spectroscor: (ICP-AES) employing a JY Ultima 2C spectrometer at Kingston Universid I undon. The instrument was calibrated using a range of sedimentary rock refe ance materials. The analytical protocol follows Olde et al. (2015). $\mathrm{CaCO}_{3}$ values wt:e c.lculated from bulk sediment $\mathrm{Ca}$ contents assuming that Ca resides only in the canhor ice fraction. Aluminium contents are expressed as weight percent oxide. By rei $r_{t}:$ e to international reference materials run with samples, accuracy and precisio. . vere judged to be $<3 \%$. $\mathrm{CaCO}_{3}$ and $\mathrm{Al}_{2} \mathrm{O}_{3}$ data are reported in

\section{Supplementary Material Table 1.}

\subsection{Palynological database}

Most of the data on the spatial and temporal distribution of the selected stratigraphically important species were taken from the PALYNODATA database (Palynodata Inc and White, 2008), compiled over the last 25 years under the auspices of several major oil companies and the Geological Survey of Canada. The database is freely available and stores taxonomic, bibliographic, geographic and biostratigraphic information from all known pre-Quaternary palynological publications up to 2006 
(https://gcmd.nasa.gov/records/CANADA-CGDI_Canada_GSC_PalyLit.html). For completeness, the taxonomy of all species discussed is reviewed, and synonyms are included in the database interrogation. Over 5000 entries for the species considered in this study exist, and their geographic locations are here condensed to 212 localities, including DSDP and ODP sites. Species records were supplemented by data from references missing in PALYNODATA, plus personal observations.

Every effort was made to check all cited references, to confirm species identifications where possible, and to determine the most likely spatial and temporal range of each species. To distinguish between chronostratigraphic position and age, we refer to the stratigraphically lowest and highest occurrence in : ndividual sections as the LO (lowest occurrence) and HO (highest occurrence). If th 'se events appear to represent the maximal range or the recognised incep'ic ? $n$. extinction of the species, the terms FAD (first appearance datum) or LAD (lisı $:$ ppearance datum) are used.

\subsection{Palaeogeographic mapping}

Dinocyst distribution data were tak _.. fr ${ }^{m}$ Palynodata Inc and White (2008) with additional information from: Wilson (1; 4); Marshall and Batten (1988); Prössl (1990); Schiøler (1992); Dodsworth (2004a, i 2016), Lebedeva (2006, 2008, 2010); McPherson et al. (2006); Wagreich et al. (200u), Z ıct et al. (2006); Gedl (2007); Bubík et al. (2008); Calis and Drummond (2008); L. snum (2008); Nicolas (2008); Nikitenko et al. (2008); Skupien and Mohammed (20)ठ; Soliman et al. (2008, 2009); Masure and Vrielynck (2009); Moradin and All-mt:- (2010); Peyrot et al. (2011); Mohamed et al. (2012); Nøhr-Hansen (2012, गa _ama et al. (2014); Nøhr-Hansen et al. (2018); Dodsworth and Eldrett (2019); Eldret. $-t$ al. (2019) and personal observations. A summary table of the geographic localities is shown in Supplementary Material Table 3.

GPlates 2.1 (www.gplates.org) was employed to rotate the data points back to their original palaeogeographic positions. GPlates is an open-source, plate tectonic geographic information system that allows the manipulation of plate-tectonic reconstructions through geological time (Matthews et al., 2016; Müller et al., 2018). The geomagnetic rotations were updated from Gee and Kent (2007) to the GTS2016 timescale (Ogg et al., 2016). Within the relevant age interval, the GTS2016 model modifies the ages of the Late Cretaceous isochrones slightly from those used by Gee and Kent (2007), placing the young end of magnetic polarity chron M0r at 125.95 Ma rather 
than at 120.6 - $121 \mathrm{Ma}$. In addition, C33n, C33o and C34n ages are modified respectively from 73.6, 79.1, 83.0 Ma to 74.3, 79.9 and 84.2 Ma. The resulting differences are marginal and likely within the error. Similarly, no significant differences to the GTS2016-calibrated plots were observed when adopting the new age model presented here, or the proposed GTS2020 time scale (see Section 4.5).

The palaeogeographic maps presented here, based on Cao et al. (2017), employ the palaeomagnetic reference frame to construct an 'absolute' plate motion model that may be used for palaeolatitude analysis through time-correcting the plates palaeo-positions relative to the spin axis of the Earth (Torsvik et al., 2012; Matthews et al., 2016). Data points were rotated from their present-day geographic coord ${ }_{1}$-ates (latitude/longitude WGS1984) using GPlates 2.1. The maps are projected usir ${ }_{c}^{\top}+t_{2}$ World Geodetic Position WGS 1984 geographic coordinate system.

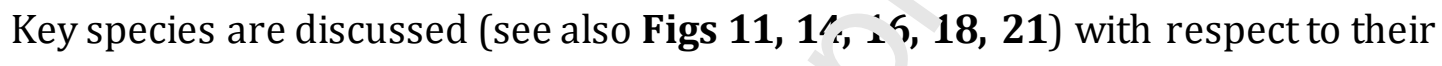
palaeogeographic distributions plotted on Figs 10, 1: 15, 17, 19-20). With the exception of India and to a lesser extent Aust. a'.la the majority of plates experience dominantly E - W motion during the Le $i c$.r. ${ }^{+}$aceous and, therefore, only minor differences exist in their palaeolatitudin. 'position. Given errors inherent in the calculation of palaeolatitudes, an ave ' ge value for the five time-slices is provided in the text. Five palaeogeographic maps der ved from the reconstructions of Cao et al. (2017) are produced for the earliest: C.nomanian; Turonian; Coniacian; Santonian; and Campanian. The age of the $0_{5}$ raphic configuration closest to the species event under discussion is used to illurtraic the species spatial distribution. Particular effort was made to check outlie - $\sigma_{\text {: }}$ jpurious occurrences of dinocyst taxa.

Palaeoclimate zor - , for the latest Early Cretaceous (Late Albian) and mid-Late Cretaceous (Early Campanian), compiled by Scotese et al. (2014), are plotted on the palaeogeographic maps to assess whether a species is confined to specific palaeoclimate belts. Only a limited range of palaeoclimate maps were provided by Scotese et al. (2014): Late Albian climate belts are plotted on the Cenomanian maps; Early Campanian climate belts are used for the other time slices.

\subsection{Age model}

Age constraints for the Cenomanian through Campanian interval at Trunch are provided by radioisotopic and astrochronological ages of macrofossil biostratigraphic 
datum levels, global carbon-isotope excursions, and the base Chron C32 geomagnetic reversal, interpreted in previous studies (Sageman et al., 2006, 2014; Voigt and Schönfeld, 2010; Husson et al., 2011; Voigt et al., 2012; Meyers et al., 2012; Ogg and Hinnov, 2012; Ma et al., 2014; Laurin et al., 2014; Thibault et al., 2016; Gambacorta et al., 2019). A total of 30 age-control points is applied to the Upper Cretaceous at Trunch (Fig. 8, Table 1). The age-depth relationships between these points are estimated using piecewise cubic Hermite interpolating polynomial function (pchip) in the Matlab R2018b Curve Fitting Toolbox. The individual age-control points are equipped with uncertainties related to stratigraphic correlation, sampling resolution, and those inherent in the radioisotopic measurements and astrochronor oical interpretations. Between the age-control points, the uncertainties are linea ${ }^{-l v}$ nterpolated.

Recently published chronological constraints (se a an e) make it possible to update the age calibration of the English Chalk carbon-isc $\omega_{p} \geq_{1}$ eference curve of Jarvis et al. (2006). The composite profile is constructed using wita from five sections: Dover; Eastbourne; Culver; Trunch; and Speeton $\left(\mathbf{F i}_{2} \mathbf{r}^{\prime} \mathbf{\prime}\right)$ Each section is tied to a series of age control points (Supplementary Mater'a: Ta hles 4 - 7), and an age-depth model is constructed using shape-preserving pie 'wise cubic interpolation. Because the interpolated ages are sensitive to loca' variations in sedimentation rates, it was necessary to introduce a series of uf cc ndary age control points at the junctions of the composite carbon-isotope plci. Age estimates at these levels are obtained as an arithmetic mean of interpoìteci ages between the primary age control points. An exception is the base Midrlt Soniacian in the Trunch and Culver data series, which is tuned to the Trunch 1 - fe: $n$ nce section.

The international _-ologic timescale of Ogg et al. (2016), updated from GTS2012 of Gradstein et al. (2012), is currently in revision. The forthcoming publication, GTS2020, currently adopts the following ages for Late Cretaceous stage bases (F. Gradstein pers. comm., September 2019): Cenomanian $100.5 \pm 0.1 \mathrm{Ma}$; Turonian $93.9 \pm 0.2 \mathrm{Ma}$; Coniacian $89.4 \pm 0.2 \mathrm{Ma}$; Santonian $85.7 \pm 0.1$; Campanian $83.6 \pm 0.1$; Maastrichtian 72.2 \pm 0.2 . The justification of these age assignments has yet to be published, and there remains a possibility that some changes may be made. However, in addition to the age s calculated using the model presented in this paper, we have recalibrated the age-depth model for Trunch and the English Chalk $\delta^{13} C_{\text {carb }}$ reference curve (Jarvis et al., 2006) using the unpublished GTS2020 ages with a view to offering compatability for future 
workers adopting that time scale. The alternative ages of the bioevents are listed in Appendix B.

\section{Carbon and oxygen stable-isotope stratigraphy}

Carbon isotope data (Jenkyns et al., 1994; Jarvis et al., 2006) and established CIEs (Jarvis et al., 2006; Uličný et al., 2014; Thibault et al., 2016), integrated with lithostratigraphic marker bed correlation and macrofossil biostratigraphy (Figs 3 - 4), were employed to constrain the chronostratigraphy of the Trunch succession (Section 3.2), as summarised in Fig. 5. Identified CIEs provide significant calibration points for deriving an age model for the section (Section 4.5). The carbu $\eta$ isotope data are not considered further here.

Cretaceous pelagic and hemipelagic carbonate bu'k -er.iment and carbonate finefraction oxygen isotopes commonly preserve consisu nı stratigraphic trends that have been used to interpret variation in past sea-surfare «mperatures (Ditchfield and Marshall, 1989; Jenkyns et al., 1994; Schrag e -.1., 1995; Clarke and Jenkyns, 1999; Stoll and Schrag, 2000; Pearce et al., 2009; Jr \& s's c ${ }^{+}$al., 2015). The suitability of $\delta^{18} 0$ trends derived from bulk-sediment analyses oi halks as a palaeo-environmental proxy, is supported by compatible $\delta^{18} \mathrm{O}$ data $\mathrm{o}_{\mathrm{*}}{ }^{+}$ained from pristine brachiopod shells (Voigt, 2000; Voigt et al., 2004, 2006) anc Y la aktonic foraminifera (Voigt et al., 2010) enclosed in the same sediments, and fro.. coincident changes in macrofossil assemblages (Jarvis et al., 2011, 2015).

The oxygen isotope ${ }^{n} c_{-}-d$ at Trunch fluctuates on a sample-by-sample basis to a greater extent than $t_{1}, t_{\llcorner} \_$iarbon (Fig. 5). Detailed analysis of the $\delta^{18} 0$ trends is beyond the scope of $t_{1}^{1}:-$ paper but a number of features warrant comment. A generally rising $\delta^{18} 0$ trend through the Cenomanian at Trunch with a large trough in the Middle Cenomanian is contrary to generally falling $\delta^{18} 0$ values recorded elsewhere (Jenkyns et al., 1994; Clarke and Jenkyns, 1999; Voigt et al., 2004). The latter are interpreted to reflect the global warming of surface waters from the latest Aptian (O’Brien et al., 2017), towards the development of peak super-greenhouse climate conditions in the Early Turonian. Anomalous high $\delta^{18} 0$ values in Upper Cenomanian at Trunch do not follow this trend.

The Albian - Lower Turonian section at Trunch is highly condensed, displays numerous erosion surfaces, beds of variable bioclastic debris, and has undergone 
extensive early diagenesis associated with the development of nodular chalks and lithification and mineralisation of multiple hardgrounds (Figs 3, 5). Nonetheless, the range of isotope values for this section, between -1.8 and $-3.2 \delta^{18} 0$, lies within the range of values typically recorded from shallow buried chalks of this age in NW Europe (e.g. Jenkyns et al., 1994; Wilmsen, 2007). Oxygen isotope values remain uncharacteristically high through the Lower and Middle Turonian at Trunch, by comparison to other European sections (Voigt and Hilbrecht, 1997; Stoll and Schrag, 2000; Voigt and Wiese, 2000; Voigt et al., 2007, Jarvis et al., 2015), but then step down to lower values in the high Middle Turonian, above the 'Pewsey' CIE. The reason for the anomalous $\delta^{18} 0$ trend in the Cenomanian - Middle Turonian is 'inclear.

A series of $\delta^{18} 0$ peaks and intervening troughs in the Linn,$r$ Turonian compare well to the positions of similar peaks elsewhere in Europe 1'av ma around the 'Pewsey', Caburn, and Hitch Wood CIEs (Fig. 5) have been ir ce, ?I eted to represent episodes of stepped cooling during the Late Turonian (interva's , - III), associated with influxes of north Boreal 'cool water' macrofaunal taxa in - $\mathrm{n} n$ 'rthern and central Europe (as

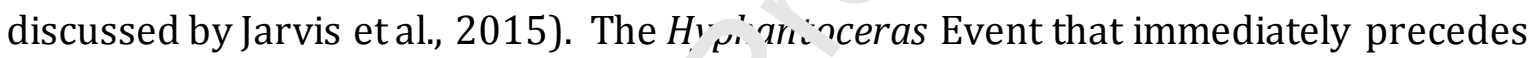
the Hitch Wood CIE (Figs 3, 5 interval $: \bullet$ ), is an example of one of these cool-water pulse faunas. Low $\delta^{18} 0$ values in the npermost Turonian at Trunch, rising to a peak around the Beeding CIE, is a trend o ss erved elsewhere (Jarvis et al., 2015).

A medium term $\delta^{18} 0$ minir.' 1 m in the low Middle Coniacian, around the level of the White Fall CIE (Fig. 5), is fo.'? $\mathrm{w}$ d by generally rising values through the remainder of the section, as also seen $=+$ L = ver in SE England (Jenkyns et al., 1994). This is interpreted to repres $\eta_{\llcorner} \stackrel{\text { L }}{\mathrm{e}}$ e onset of a period of accelerating long-term cooling that characterised the remi: ${ }^{\prime}$ der of the Late Cretaceous (O'Brien et al., 2017). More detailed analysis of the $\delta^{18} 0$ profile is compromised by a lack of stratigraphically wellconstrained oxygen isotope records from comparable NW European sections.

\section{Palynological results}

A total of 267 samples were analysed from 512.43 - 270.0 m (Albian - Lower Campanian). The single sample from Albian Hunstanton Formation 'Red Chalk' at $512.43 \mathrm{~m}$ was barren and will not be discussed further. Twenty-six samples were taken from the condensed Cenomanian, 84 samples from the Turonian, 54 samples from the 
Coniacian, 64 samples from the Santonian and the remaining 38 samples from the low Lower Campanian.

A summary relative abundance range chart of selected taxa is presented in Fig. 6; the entire data set is provided in Supplementary Material Table 2. The absolute abundance and specific diversity profiles are presented in Fig. 7. Taxa grouped as undifferentiated species (i.e. Alterbidinium spp.) are included in the sum of species richness. For simplicity, the genera Alisogymnium and Dinogymnium are included as dinocysts although they probably represent the ecdysal pellicles of dinoflagellates.

The palynoflora is dominated by 184 species and subspecies of dinocysts (particularly, Spiniferites ramosus subsp. ramosus, and signiticant numbers of Palaeohystrichophora infusorioides and Achomosphaera ra. 'u' fera throughout). Acritarchs (Fromea spp., Palaeostomocystis reticulata t rrr ecaniella indentata,

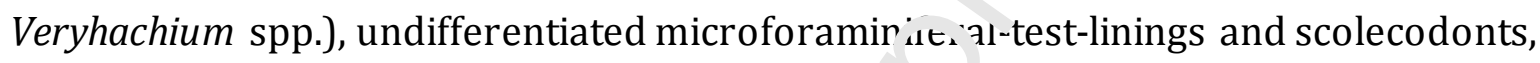
prasinophytes (Cymatiosphaera spp., Pterosperme'la -np., Tarsisphaeridium geminiporatum), spores and pollen (includin ${ }$ is iccate gymnosperm pollen) and the colonial marine alga Palambages morul s. ${ }^{\vee} \mathrm{a}_{1} \mathrm{2}$ also present. Conspicuous changes in the palynomorph assemblages and notable . . ecies influxes are described below. Significant species events are described in Sectı $\mathbf{\eta} 7$.

\subsection{Cenomanian (Ferriby r... alky}

A distinct decrease in $t_{1} \sim p_{1}$ oportion of Palaeohystrichophora infusorioides and Spiniferites ramosus sub?n , $\approx$ nosus occurs from the lower Mantelliceras mantelli Zone to the upper Mantelı $r_{m}$ - dixoni Zone and is broadly mirrored by an increase in the proportion of Pterodi. : $m$ cingulatum subsp. cingulatum, Sepispinula? ambigua and Spiniferites twistringiensis. The opposite trend is observed up to the mid-Acanthoceras rhotomagense Zone. Achomosphaera ramulifera, Downiesphaeridium armatum and Tenua colliveri are generally more numerous in the Lower Cenomanian, and an increase in numbers of Litosphaeridium siphoniphorum subsp. siphoniphorum and Oligosphaeridium complex is observed from the mid-M. dixoni Zone to the mid-A. rhotomagense Zone. A major collapse in recovery is observed in the Middle Cenomanian at $503.3 \mathrm{~m}$ (mid-A. rhotomagense Zone), marking the base of an interval of poor recovery (generally barren) that extends to the base of the Upper Turonian. For simplicity, this interval is referred to as the 'barren' beds. 
Dinocyst species richness and diversity are high below the 'barren' beds, with an average of 49 species (H 3.06), and generally higher in the Early Cenomanian with 57 (3.3) at $507.9 \mathrm{~m}$ in the mid-M. dixoni Zone (Fig. 7). Absolute palynomorph abundances per gram (ppg) broadly increase through the Lower and Middle Cenomanian to a maximum of 2921 (113,076 carbonate-corrected) ppg at $505.8 \mathrm{~m}$, prior to the upper $A$. rhotomagense recovery collapse (Figs 7, 11). Above $503.8 \mathrm{~m}$ to $501.3 \mathrm{~m}$ (mid-A. rhotomagense to upper Calycoceras guerangeri zone) recovery is extremely poor, and from 501.0 - 500.1 m (Metoicoceras geslinianum Zone) no specimens were recorded.

\subsection{Turonian (Welton Chalk - lower Burnham Chalk)}

A temporary recovery of palynomorphs occurs at $474.7 \mathrm{r}$. and $473.6 \mathrm{~m}$ in the Upper Turonian, uppermost Terebratulina lata Zone (Figs 6 - 7). lowever, the base of the main recovery interval occurs at $469.0 \mathrm{~m}$. Achomc spi rera ramulifera, Downiesphaeridium armatum and Tenua colliveri bru dly increase in number upwards through the Plesiocorys (Sternotaxis) plana Z( $\mathrm{n}\lrcorner$, vhereas Achomosphaera regiensis and Pterodinium cingulatum subsp. cingula ${ }_{\mu}$.' b.' 'nadly decrease in number. A bimodal distribution of $P$. infusorioides is consplc ous with highest numbers in the lower midand upper P. (S.) plana Zone. Betwet. these maxima, an increase in the proportion of Achomosphaera ramulifera, Isabelıdini im cooksoniae, S. ramosus subsp. ramosus and $S$. twistringiensis is observed.

Above the 'barren' beds diı ) cyst species richness and diversity broadly increase from $42(2.95)$ at $469.0 \mathrm{~m}$ th $56(3.26)$ at $437.0 \mathrm{~m}$ prior to declining to 48 (3.00) at $430.0 \mathrm{~m}$, with an ave ' $\mathrm{g}_{\text {L. Jiversity of }} 47$ (3.00; Fig. 7). Excluding the interval from 439.0 - $433.3 \mathrm{~m}$ wher - elatively low absolute abundances appear to be related to an increase in density of nodular chalk (and therefore, possible lowered due to current winnowing), values broadly increase through the Upper Turonian (with a maximum of 1,072,107 ppg at $446.0 \mathrm{~m}, \sim 4 \mathrm{~m}$ above the 'Chalk Rock' beds; Figs 7, 14).

Two phases of Cenomanian reworking occur in the Upper Turonian from 469.0 $461.0 \mathrm{~m}$ (base $P$. (S.) plana Zone), and particularly from 436.0 - $433.0 \mathrm{~m}$ (uppermost $P$. (S.) plana Zone; 'i5' CIE, immediately below the Navigation Hardground).

\subsection{Coniacian (Burnham Chalk)}


The Lower Coniacian (Micraster cortestudinarium Zone) is marked by a significant influx of Palaeohystrichophora infusorioides with an acme at $426.0 \mathrm{~m}$, the remainder of the stage displays little change. Conspicuous influxes of Canningia glomerata and Spiniferites ramosus subsp. aquilus are observed in the upper M. cortestudinarium Zone, and Heterosphaeridium verdieri in the Middle Coniacian (Micraster coranguinum Zone).

Palynomorph species richness and diversity have averages of 43 (2.71) and broadly decline upsection, although maxima of 52 (3.15) and 50 (2.83) occur at $411.0 \mathrm{~m}$ and $393.0 \mathrm{~m}$ in the basal Middle and mid-Middle Coniacian (M. coranguinum Zone), respectively (Fig. 7). A minimum of 32 (2.61) dinocyst taxa are recorded at $377.0 \mathrm{~m}$ in the mid-Upper Coniacian (M. coranguinum Zone). Three inter . als of increasing absolute abundances occur through the Coniacian, two in the Lowe. Cr niacian (M. cortestudinarium Zone) and the third spanning the M d ' le and Upper Coniacian (Figs 7, 16). The lowermost phase is a continuation of risi ig ratues from the Upper Turonian to a maximum of $5333(624,539)$ ppg at $425.0 \mathrm{~m}$, the st ${ }^{\circ} \mathrm{nd}$ phase rises from 843 $(110,198)$ at $424.0 \mathrm{~m}$ to $11859(1,517,372)$ a $\triangle 12.0 \mathrm{~m}$ and the third from 1791 $(183,981)$ at $411.0 \mathrm{~m}$ to $5255\left(451,025 ; \mathrm{a}^{+} 3.73 .0 \mathrm{~m}\right.$. Minor Cenomanian reworking is noted at $379.0 \mathrm{~m}$.

\subsection{Santonian (upper Burnhain $C \mathrm{~J}$ alk and Flamborough Chalk equivalent)}

A number of influxes char terise the Santonian. In the Lower Santonian (M. coranguinum Zone), commu $n$ tu very abundant Spinidinium echinoideum is recorded from $367.0-362.0 \mathrm{~m}$ (a $\sim \mathrm{m}_{t}=. .364 .0 \mathrm{~m}$, where it comprises almost $40 \%$ of the sample). In the Middle Santon. ' ${ }^{\prime}$ 'n'. coranguinum Zone), Palaeoperidinium pyrophorum has an influx in the lower pai : $(356.0-351.0 \mathrm{~m})$, and Isabelidinium cooksoniae in the upper part (346.0 - $336.0 \mathrm{~m})$. In the Upper Santonian (Uintacrinus socialis Zone), Chatangiella eminens is particularly prominent from $334.0-326.0 \mathrm{~m}$.

Species richness and diversity generally decrease up section from 50 (2.92) at 372.0 $\mathrm{m}$ to 40 (2.45) at $307.0 \mathrm{~m}$, with an average of 43 taxa per sample (Fig. 7). Numbers are relatively consistent through the Lower and Middle Santonian (M. coranguinum Zone) with an average of 45 (2.74), decline into the Upper Santonian (U. socialis Zone) with an average of 40 (2.44), and increase through the remaining Marsupites Zone with an average of 44 (2.64). This reduction of species richness in the U. socialis Zone is associated with marked trough in Shannon diversity. Absolute dinocyst abundances 
decline steadily upsection from $5394(419,056) \mathrm{ppg}$ at $372.0 \mathrm{~m}$ to $597(41,699) \mathrm{ppg}$ at $307.0 \mathrm{~m}$ (Figs 7, 18).

As with the Upper Turonian, sporadic Cenomanian reworking occurs in the Santonian, particularly at the base, over the Lower - Middle stage boundary and in the Upper Santonian (Marsupites Zone).

\subsection{Lower Campanian (Flamborough chalk equivalent)}

For the Lower Campanian, only the Offaster pillula and lowermost Gonioteuthis quadrata zones are included in the present study. Notable rompositional changes

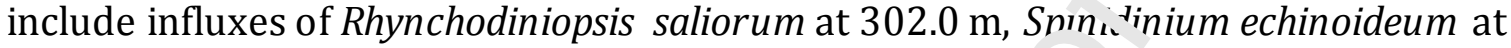
$295.0 \mathrm{~m}$, and Tenua colliveri at $281.0 \mathrm{~m}$ where it dominate. th : assemblage.

Palaeohystrichophora infusorioides and Spinidinium e hin leum decrease in numbers upsection, in direct contrast to Senoniasphaera prc cr u sa

A broad upsection increase in species richnes: $a_{1 .}$. 1 diversity is observed from 41 (2.36) at $306.0 \mathrm{~m}$ to $48(2.63)$ at $270.0 \mathrm{~m}$ (Fi६ . ). Absolute dinocyst abundances remain relatively low from the Santoni . .1 vl' an average value of $931(47,886)$ ppg to $288.0 \mathrm{~m}$ to the mid-O. pillula Zone. Froı, this level, values increase steadily to the top of the studied section at $270.0 \mathrm{~m}$, with a ralue of $9877(828,938)$ ppg (Figs 7, 21). Cenomanian reworking is observed at $305.0 \mathrm{~m}$ and $279.0 \mathrm{~m}$.

\section{Palynological bioeven:s a. ad palaeogeographic distribution of marker taxa}

The temporal and sratla. distribution of key taxa (including their synonymies) have

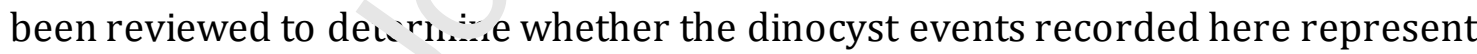
regional stratigraphic $\mathrm{d}$.stributions (lowest occurrence, LO; highest occurrence, HO) or the full stratigraphic range of species (first appearance datum FAD, inception, to last appearance datum LAD, extinction), and how geographically widespread the events may be. The accurate determination of a species FAD and LAD is dependent on the availability of a geographically and stratigraphically widely distributed database. Accordingly, where LO and $\mathrm{HO}$ events coincide with the known maximum range, we take these as probable LAD and FAD events. Where dinocyst events are documented to occur within a limit portion of accepted ranges, or there is minimal available supporting data regarding the wider significance of the datum levels, we refer to LO and HO events. 
Forty-eight taxa from the Trunch borehole are considered to have 65 significant events (see Appendix B), which are compared with available literature. The dinocyst events are plotted against the $\delta^{13} \mathrm{C}_{\text {carb }}$ profile and CIE stratigraphy of the Trunch borehole and correlated to the recalibrated English Chalk carbon-isotope reference curve of Jarvis et al. (2006; Fig. 9) in Figs 11, 14, 16, 18, 21. The age vs. depth model for the Trunch borehole illustrated in Fig. 8, provides the basis for dating individual palynological events. This plot demonstrates a wide variation in sediment accumulation rates (uncorrected for compaction) ranging from a minimum of $0.25 \mathrm{~cm} \mathrm{kyr}^{-1}$ in the Cenomanian to a maximum of $7.35 \mathrm{~cm} \mathrm{kyr}^{-1}$ for the Upper Turonian, the interval of the Northern Province Flint Maximum. Maximum biostratigranhic resolution is provided by palynological events in the Late Turonian, around the Tır ni-n - Coniacian boundary, and in the Santonian - earliest Campanian (Fig. 8). A z events are considered in the discussion below (Se ac ns 7.1 - 7.5).

Species distributions plotted on palaeogeograph - maps derived from the reconstructions of Cao etal. (2017) are provi $t$ d d n Figs 10, 13, 15, 17, 19 - 20, with

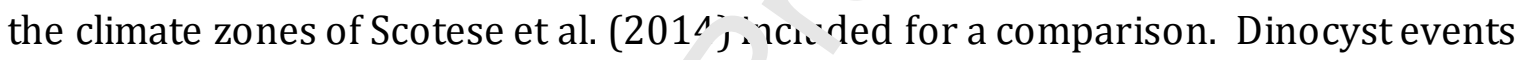
are summarised in Appendix B and in S. rtion 8, below.

Significant differences have long $\llcorner$ sen recognised between the clastic-prone Upper Cretaceous sequences of the Nortı 'e' $ı$ and Norwegian-Greenland Sea (Shetland Group) to those of the more southerl' ‘ halk-prone sequences (Chalk Group). Notable absences of many Shetland Group má.keı species (e.g. Chatangiella islae, Heterosphaeridium

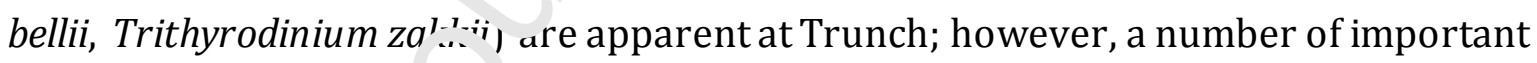
marker species are cu $\eta_{1 . .} \mathrm{n}$ between these two areas (e.g. Alterbidinium ioannideii, Cyclonephelium memb, uniphorum, Epelidosphaeidia spinosa, Rhynchodiniopsis saliorum, Sindridinium borealis, Stephodinium coronatum, Surculosphaerium longifurcatum). As pointed out by Costa and Davey (1992), a substantial number of undescribed or inadequately know species from onshore and offshore UK are known, and many of these have now been dealt with in Prince et al. $(1999,2008)$ and Pearce $(2011,2018)$. New data from Late Cretaceous outcrop material of Greenland (Nøhr-Hansen et al., 2019) is helping to improve our understanding of the northerly clastic-prone sequence palynology, while we consider our data here, to be the most detailed record from the (southern) Chalk Group. 


\subsection{Cenomanian}

Ten species with 12 selected events are discussed: (1) LO and (2) HO of persistent Sindridinium borealis; (3) LAD of Disphaeria munda; (4) LAD of Sidridinium borealis; (5) LAD of Hapsocysta peridictya; (6) LAD and HO of common Epelidosphaeridia spinosa; (7) HO of persistent Cribroperidinium? edwardsii; (8) HO of persistent / common Litosphaeridium siphoniphorum; (9) HO of common Sepispinula ambigua; (10) LAD of Pterodinium crassimuratum; (11) LAD of Wrevittia cassidata; (12) LAD of Carpodinium obliquicostatum.

\subsubsection{LO persistent, HO persistent and LAD of Sindridiniu.? borealis (NW Europe)}

\section{Taxonomy and geographic distribution}

Sindridinium borealis (Plate V, 11 - 12) has onlv 1 cently been described by NøhrHansen et al. (2018), but it has long been recognist $d \mathrm{~L} y$ the hydrocarbon exploration industry as an important marker species for t'ie i ower Cenomanian. The form is typically referred to as "Sidridinium borenli." [sıc] in unpublished biostratigraphic reports, but has been recorded as Ovo. ${ }^{\text {Jir } ~}$ um ? sp.1 from NE Greenland (Nøhr-Hansen, 1993) and offshore NW Norway (Ka tmacher, 2014). Care must be taken in assigning all records of Ovoidinium? sp.1 of Nø' (r. I'nnsen 1993 to S. borealis as the former taxon includes hypocavate forms that arc now referred to as Sindridinium anaanae NøhrHansen et al., 2018; these weı not observed in the present study. Sindridinium borealis has also been observed fru $\eta t$ le Troms and Hammerfest basins, offshore north -west Norway by Costa (1?8s ] ar d occurs extensively through the Norwegian Sea and northern North Sea (Pećrce pers. obs.; Fig. 10a) as a 'Boreal warm' species. The occurrence of the taxon in the Trunch borehole is currently the most southerly occurrence known.

\section{Stratigraphy}

The probable FAD of Sindridinium borealis occurs in the Upper Albian (NøhrHansen et al., 2018), but common occurrences are only known from the Lower Cenomanian. The highest occurrence of S. borealis (Sbo) in the Trunch borehole at $506.4 \mathrm{~m}$ (Figs 6, 10 - 11) appears to represent the LAD of the species, with a calculated age here of $96.42( \pm 0.5)$ Ma. Frequently recorded specimens from $507.3-509.3 \mathrm{~m}$ 
(restricted to the M. mantellii Zone) appear to approximate the range of commonly recorded specimens by Nøhr-Hansen et al. (2018) with a calculated age range here of $96.77( \pm 0.51)-97.58( \pm 0.53)$ Ma.

\subsubsection{LAD of Disphaeria munda (NW Europe)}

\section{Taxonomy and geographic distribution}

Disphaeria munda (Plate II, 6) was first described as Thalassiphora munda by Davey and Verdier (1973) from the Albian and Cenomanian of France. It was considered by Yun (1981) to be a junior synonym of T. dyna: : ${ }^{i} \mathrm{Ca}$ (Morgenroth 1966) Stover and Evitt, 1978 (originally described from the Low $\mathrm{r}$ E cene of Germany). However, Lentin and Williams (1985) retained T. munı 'a. \& lthough there is a striking morphological similarity between these species, the $n_{1}$ ?bable Early Cenomanian LAD of T. munda (see below), suggests that these species a distinct (unless T. dynamica is based on a reworked specimen of T. munda), 'Ju . a detailed analysis of both holotypes is required to be conclusive. Disphaeria mun $r$ is restricted to the Northern Hemisphere in a narrow latitudinal band from $\sim 66^{\wedge} \mathrm{N}$, offshore mid-Norway, pers. obs.) to $\sim 39^{\circ} \mathrm{N}$ (Colorado: Courtinat, 1993) and is ivend in North America, North Atlantic and western Europe.

The palaeolatitudal range $\mathrm{r} \sim \mathrm{f} \sim 7^{\circ} \mathrm{N}$ (offshore mid-Norway, pers. obs.) to $\sim 32^{\circ} \mathrm{N}$ (northern Spain: Lamolda anu Mao, 1999; Fig. 10b) indicates that this species was a 'Boreal tropical' to 'Boreaı 'va' $m$ ' species

\section{Stratigraphy}

The majority of records indicate that D. munda occurs persistently to the top of the Lower Cenomanian (Davey, 1979; Fauconnier, 1979; Foucher, 1980, 1981; Tocher and Jarvis, 1996), or within the Middle Cenomanian (lower A. jukesbrownei Zone; Marshall, 1983), but rare specimens have been recorded from the uppermost Cenomanian (Pearce et al., 2009) and lowermost Turonian from southern UK (Tocher, 1984), and Colorado (USA; Courtinat 1993). Assuming that uppermost Cenomanian and Turonian occurrences are based on reworked specimens, the LAD of D. munda is suggested to occur in the Early Cenomanian. The HO of D. munda (Dmu) at $507.3 \mathrm{~m}$ in the Lower Cenomanian (M. dixonii Zone; Figs 6, 11) of the Trunch borehole is consistent with the 
majority of published records and appears to approximate the LAD with a calculated age here of $96.77( \pm 0.51)$ Ma.

\subsubsection{LAD of Hapsocysta peridictya (worldwide)}

\section{Taxonomy and geographic distribution}

Hapsocysta peridictya (Plate II, 11) was recognised as new and described from the Aptian to Cenomanian from the Canarvon Basin of Western Australia by Eisenack and Cookson (1960; as Cannosphaeropsis peridictya) after being originally attributed to Cannosphaeropsis fenestrata (now Aiora fenestrata) by Cook ^n and Eisenack (1958). Its generic status was questioned by Stover and Evitt $(19 ; 8)$ a d the species was subsequently transferred to Hapsocysta by Davey (197 Э). , t is recorded from both hemispheres: from $\sim 66^{\circ} \mathrm{N}$ (offshore mid-Norway, nor o obs.) to $\sim 11^{\circ} \mathrm{N}$ (Tamil Nada India: Jain, 1977; Venkatachala and Kumar, 1980) t! te Northern Hemisphere; and from $\sim 6^{\circ} \mathrm{S}$ (Papua New Guinea: Davey, 1988) io $71^{\circ} \mathrm{S}$ (ODP 692 and 693, Weddell Sea, Antarctica: Mohr, 1990) and is distributed i rough the North America, North Sea, North and South Atlantic, Antarctica, Indian i $r$ an and Australia as a sub-tropical to warm temperate species.

The palaeolatitudinal range o $\sim \operatorname{r}^{\circ} \mathrm{N}$ (offshore mid-Norway, pers. obs.) to $\sim 21^{\circ} \mathrm{N}$ (North Atlantic, DSDP 418: Hor nui and Kelts, 1979) in the Northern Hemisphere and $\sim 28^{\circ} \mathrm{S}$ (Campos Basin, Brazil: ^ ${ }^{1}$ rai and Masure, 1997) to $\sim 69^{\circ} \mathrm{S}$ (ODP 692, 693, Weddell Sea, Antarctica: Mohr 199?? ir dicates that this species was adapted to both 'arid' and 'Boreal warm' clima'⿳亠 L olts (Fig. 10c).

\section{Stratigraphy}

Numerous records place Hapsocysta peridictya in the Aptian and Albian. However, Eisenack and Cookson (1960), Verdier (1970), Masure (1984), Mohr et al. (2002) and Shipboard Scientific Party (2004) indicate that the HO occurs in the Cenomanian. The HO of Hapsocysta peridictya (Hpe) at $504.8 \mathrm{~m}$ in the Middle Cenomanian ( $A$. rhotomagense Zone) at Trunch may therefore correspond to the LAD of the species, with a calculated age of $95.84( \pm 0.44)$ Ma (Figs 6, 11). 


\subsubsection{LAD and HO of common Epelidosphaeridia spinosa (N. Hemisphere)}

\section{Taxonomy and geographic distribution}

Epelidosphaeridia spinosa (Plate II, 9) was originally (and invalidly — see Williams et al., 2017) described as Palaeoperidinium spinosum by Cookson and Hughes (1964) from the ?Lower Cenomanian of SE England. It was validly referred to as Epelidosphaeridia spinosa by Davey (1969). The species has been recorded from India (Venkatachala and Kumar, 1980) but on examining the plates, we feel the illustrated specimen is too dissimilar to the holotype to be counted. Two additional records from India (Jain and Taugourdeau-Lantz, 1973; Mehrotra et al., 2: ^2) have not been checked and are tentatively included as geographic outliers. The $r$ 'ma ning records indicate that it is restricted to the Northern Hemisphere from 74ㅇ I ( $\mathrm{e}_{i}$ stern Greenland: NøhrHansen, 1991, 1993) to $\sim 25^{\circ} \mathrm{N}$ (ODP 635, The Bahama : Masure, 1988) and is found in North America, western and southeast Europe ana "rrth Africa.

The palaeolatitudal range of $\sim 81^{\circ} \mathrm{N}$ (nortie $n$ Alaska: Witmer et al., 1981 ) to $\sim 22^{\circ} \mathrm{N}$ (northeast Algeria: Foucher et al., 1994; $\mathbf{F i}_{\mathbf{b}}$ 10a) indicates that this species was restricted to the north 'arid' and norti. ' $R$ jreal warm' climate belts.

\section{Stratigraphy}

The bulk of the literature cl _ rly places the highest occurrence of Epelidosphaeridia spinosa in the Cenomanian. $\Lambda_{\mathrm{s}} \mathrm{O}_{1}$ ? of the earliest studies on the stratigraphic distribution of the species the work of Clarke and Verdier (1967) at Culver Cliff, Isle of Wight (southern UK) is par icularly useful as it also provided quantitative data that can now be directly compaı 'd to the $\delta^{13} C_{\text {carb }}$ record (Fig. 12; Jarvis et al., 2001, 2006). Clarke and Verdier (1967) recorded the highest occurrence of E. spinosa in sample 11 (reported as within the lower Grey Chalk) and the highest frequent occurrence (where it reaches $5 \%$ of the total assemblage) in sample 8 (reported as within the upper Chalk Marl). Clarke and Verdier (1967) equated the top of the Chalk Marl with the top of the traditional Schloenbachia varians ammonite Zone. Their measured section corresponds closely to that presented by Jukes-Browne and Hill (1903). However, the S. varians Zone includes both the Chalk Marl and the lower part of the Grey Chalk (Jukes-Browne and Hill, 1903). 
The main lithological break at the base of the Grey Chalk at Culver Cliff (cf. Gale et al., 1999 fig 2; Jarvis et al., 2001,2006) occurs at $23.0 \mathrm{~m}$ above the base of the Cenomanian on Clarke and Verdier's (1967 text-fig. 2) measured section at Culver Cliff, and not at $36.7 \mathrm{~m}$ as indicated on their log. This is significant because their samples 6 9 thus all fall within the lower Grey Chalk (Middle Cenomanian, A. jukesbrownei Zone) rather than in the Chalk Marl as interpreted by them. The sample positions and dinocyst records of Clarke and Verdier (1967) are replotted against the stratigraphic log of Jarvis et al. $(2001,2006)$ in Fig. 12, and we determine samples 8 and 11 to be located in the Middle Cenomanian (mid-A. rhotomagense Zone) and lower Upper Cenomanian (lower C.guerangeri Zone), respectively.

Other studies also place the highest occurrence of $E . s_{L}{ }^{i n} r ; a$ in the low Upper Cenomanian. Davey (1969, p.143) described E. spino a to l, e rare to common in the "lower and middle horizons of the Cenomanian", b « c'iu not provide quantitative data. From his account of where the species is absent, it ap nears that the species has a highest occurrence in the lower $H$. subglobosus Zone $n$ so uthern England and the mid- $H$. subglobosus Zone in northern France. I. . he ?. ?pe Turonian area, Robazsynski et al. (1982) recorded very common E. spinos. in their lowermost sample (low Upper Cenomanian), no Middle Cenomaniar material was studied. In the absence of a complete Cenomanian dataset, the $\leqslant$ g uficance of this sample cannot be adequately assessed. Prössl (1990) also $r_{t}$-oraed the highest occurrence (with commonly occurring specimens) in the 'ov :er Upper Cenomanian. However, Prössl's study (1990) lacked independent biortrai-oraphic evidence and instead subdivided the Cenomanian section on an interpr ${ }^{+} a_{i}=11$ of sonic and resistance logs. How this was achieved was not explained, and as .... h w we cannot consider the substage assignments as definitive.

It should be noted that Mao and Lamolda (1998) described E. spinosa as having a regular distribution of rare and occasionally common specimens in the Upper Cenomanian. Lamolda and Mao (1999) illustrated the species occurring persistently through the Upper Cenomanian in the majority of samples, suggesting that such occurrences are in situ. It is therefore possible that E. spinosa has a diachronous HO between southern UK (low Upper Cenomanian: Davey, 1969; Clarke and Verdier, 1976), northern France (mid-Upper Cenomanian: Davey, 1969) and northern Spain (high Upper Cenomanian; Lamolda and Mao (1999). In the absence of high-resolution data from well-correlated sections, this is speculative, and will require testing. 
Consistent records of a Middle Cenomanian HO are also apparent. Foucher (1979, 1981) placed the highest occurrence of E. spinosa in the A. rhotomagense Zone, where specimens were reported to be particularly common (Foucher, 1981). Costa and Davey (1992) and Wilkinson et al. (1993) placed the HO of E. spinosa in the A. jukesbrownei Zone, and these have been taken as standard references by biostratigraphers working in NW Europe. Costa and Davey (1992) did not provide supporting references, while Wilkinson et al. (1993) cited Foucher (1979, 1981). Marshall (1983; unpublished PhD thesis) placed the highest occurrence in the upper A.jukesbrownei Zone. Williams and Bujak (1985) recorded the species from the Middle Cenomanian but placed the highest occurrence in the early Turonian (see below).

Paul et al. (1994) also consistently recorded E. spinosa thr Jugh the Cenomanian to their section top in the A. rhotomagense Zone. Toche' a ’d arvis (1994a, 1996) recorded a highest persistent occurrence of E. spin usu in the A. rhotomagense Zone but found the species to be particularly common in th L L wer Cenomanian. Tocher and Jarvis (1995) mentioned that the last commo > sc urrence of E. spinosa is generally regarded as indicative of the top of the ris $a_{1}$ Cenomanian but considered rare specimens in the Upper Cenomanian (C. _uerangeri Zone) to be in situ. Pearce et al. (2009) found rare specimens of E. spu: ssa in the Upper Cenomanian (M.geslinianum Zone) and, in the absence of obvio $\mathrm{d}, \mathrm{r}$ wworking, considered the species to have a LAD within the Late Cenomanian. F. nally, Dodsworth (2004b) recorded E. spinosa persistently in the Upper Ct`or anian of Crimea.

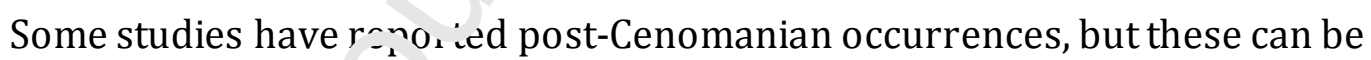
discounted. For exaı. nı, $\vdots 1$ their study of multiple wells from the Scotian Shelf and Grand Banks, Bujak ai. J. Williams (1978) stated that E. spinosa ranges from the Albian to the Cenomanian (where it become particularly common) and into the Turonian (together with L. siphoniphorum), but in greatly reduced numbers. No count data were provided and therefore, based on the apparent reduction of observed numbers in the Turonian, we presume these specimens to be reworked. Azéma et al. (1981) recorded rare E. spinosa in the Upper Santonian of Vendée France but as an outlier, is most likely based on reworked specimens. Williams and Bujak (1985) provided a stratigraphic range for E. spinosa from the uppermost Albian to the Lower Turonian, but subsequent syntheses (Williams et al., 1993, 2004) placed the LAD within the Late Cenomanian. Herbin et al. (1987) recorded E. spinosa in 4 samples spanning the Lower Cenomanian 
to Santonian interval from the west North Atlantic. Reference was made to the species as a key marker for the Upper Albian to Lower Cenomanian, but no discussion was provided for the stratigraphically higher samples. Li and Habb (1996) recorded very rare Epelidosphaeridia cf. spinosa through the Cenomanian to the lowermost Turonian from the Western Interior of USA. They did not illustrate a specimen and given the implied difference from the type specimen, their data are also excluded.

In conclusion, we recommend the LAD of Epelidosphaeridia spinosa to be in the Late Cenomanian, with a significant increase in relative numbers in the Middle Cenomanian. In Spain (Lamolda and Mao, 1999) the HO of the species ocrurs $\sim 2 \mathrm{~m}$ above the HO of Litosphaeridium siphoniphorum, and we arbitrarily place the $s_{1}$ acies together on Fig. 11, with an estimated age here of $\sim 94.2 \mathrm{Ma}$. In the UK, the hig as occurrence (Clarke and Verdier, 1967) occurs immediately below CIE b1 witt a. e timated age here of $\sim 95.15$ Ma (Fig. 11). The highest frequent/common occu rt ree of E. spinosa of Clarke and Verdier (1967) in the Middle Cenomanian (upper 1. .'kesbrownei Zone) is suggested to be a useful event that occurs immediately bel or the Jukes-Browne CIE, with an estimated age here of $\sim 95.35 \mathrm{Ma}$. In th. . ru. ch borehole the HO of Epelidosphaeridia spinosa (Esp) occurs at $504.3 \mathrm{~m}$ (mid-rhc omagense Zone; Figs 6, 11), with a calculated age here of $95.68( \pm 0.41)$ Ma. It is ra ${ }^{\circ}$, but nonetheless is a good marker for Cenomanian strata.

\subsubsection{LO of persistent Crinroperidinium? edwardsii (NW Europe)}

\section{Taxonomy and geogr: $p_{1}$ : distribution}

Cribroperidinium? er wardsii (Plate I, 12) was originally described as Gonyaulax edwardsii by Cookson and Eisenack (1958) from the Albian to Lower Turonian of western Australia. It has subsequently been transferred to Gonyaulacysta and finally to Cribroperidinium (see Williams et al., 2017). It can be easily mistaken for $C$ ? orthoceras and $C$ ? muderongense, complicating the review of its stratigraphic range; indeed Helenes (1984) considers these species (and $C$ ? intricatum) to be part of a morphological series. Available information suggests that $C$ ? edwardsii is distributed from $\sim 79^{\circ} \mathrm{N}$ (Svalbard: Smelror et al., 1998) to $\sim 64^{\circ} \mathrm{N}$ (Antarctic peninsula: Dettmann and Thomson, 1987; Olivero and Palamarczuk, 1987; Wrenn and Hart, 1988; Riding et al., 1998) and is cosmopolitan. 
The palaeolatitudal range is $\sim 81^{\circ} \mathrm{N}$ (National Petroleum Reserve, Alaska: Witmer et al., 1981; North Slope of Alaska, as C. aff. edwardsii: Kimyai, 2000; northeast Alaska: Vandergon, 1986) to $\sim 72^{\circ} \mathrm{S}$ (central South Island, New Zealand: Wilson 1982; Fig. 10e).

\section{Stratigraphy}

Cribroperidinium? edwardsii is typically recorded from the Lower Cretaceous (Smelror et al., 1998; Aguirre-Urreta et al., 1999; Duxbury, 2001; Fiet and Masure, 2001) and Upper Cenomanian (Clarke and Verdier, 1967; Norvick and Burger, 1976; Foucher, 1980; Costa and Davey, 1992; Prössl, 1990; Mohr and Gee, 1992; Pearce et al., 2009). Post-Cenomanian occurrences have been recorded ( anonian: Corradini, 1973; undifferentiated Turonian - lower Maastrichtian: Davey, : $97 £$; Santonian Maastrichtian: Ioannides, 1986) but the chronostratigı aph c control is questionable. In situ occurrences have also been suggested in the Santu nian (Yun, 1981), Campanian (Foucher, 1979; Tocher, 1987; Siegl-Farkas, 1997) _ ‘` Maastrichtian (Roncaglia et al., 1999; although Brinkhuis and Schiøler, 1996 -o isider these occurrences to be reworked), but these records appear to he. eitner consistent nor common. Therefore,

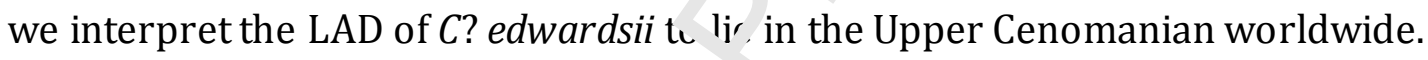

In the Trunch borehole, the hig. ast occurrence of $C$ ? edwardsii occurs at $506.4 \mathrm{~m}$ at

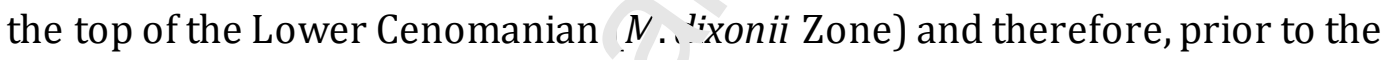
disappearance of palynomoph in he Middle Cenomanian, so this appears to be a true event (Figs 6, 11). A similar «n-persistent occurrence was recorded by Marshall (1983) in the mid-T. arcuı.' / T. costatus Zone (equivalent to the mid-A. rhotomagense Zone) from the lowc $r$. idd a Cenomanian of Germany, and Clarke and Verdier (1967;

Fig. 12) showed the higf est persistent occurrence in the Upper Cenomanian, mid $-C$. guerangeri Zone, below CIE b2. An absence of specimens in the upper Upper Cenomanian is also apparent in the study of Pearce et al. (2009) from the upper $C$. guerangeri - M. nodosoides zones of southern UK, where $C$ ? edwardsii occurred only in a single sample. The scarcity of the species in the Upper Cenomanian was corroborated by Lignum (2008, also from southern England) who recorded the top of consistent $C$ ? edwardsii in the Middle Cenomanian (intra-A. rhotomagense Zone). Based on data from the North Sea, Costa and Davey (1992) placed the HO of $C$ ? edwardsii at the Cenomanian / Turonian boundary, but significantly, placed the top of persistently occurring specimens in the Middle Cenomanian (mid-A. jukesbrownei Zone). It is uncertain how 
precisely calibrated the material in Costa and Davey (1992) was, but the range is nevertheless comparable with the results discussed here.

We suggest that the highest persistent occurrence of $C$ ? edwardsii occurs in the Upper Cenomanian (mid-C. guerangeri Zone), below CIE b2 in NW Europe, with an estimated age of $\sim 94.95 \mathrm{Ma}$. The HO of persistent $C$ ? edwardsii $(C$ ?ed) in the Trunch borehole occurs at the first sample below the Lower / Middle Cenomanian boundary with a calculated age here of $96.42( \pm 0.5) \mathrm{Ma}$, and therefore, slightly below the expected highest persistent occurrence event (Fig. 11).

\subsubsection{HO of persistent / common Litosphaeridium siphoni:hhorum (worldwide)}

\section{Taxonomy and geographic distribution}

Litosphaeridium siphoniphorum (Plate III, 9) was : ${ }^{\text {r }}$ (st described as Hystrichosphaeridium siphoniphorum by Cookson a - Eisenack (1958) from the Albian and Cenomanian of Western Australia. Masu e snd Vrielynck (2009) have previously shown that it has a bi-hemispheric distrihu: equatorial regions (an exception being $f_{r}, m$ the Demarera Rise, Eldrett et al., 2017), and high latitudes. Our distribution map (Fig. 10f) confirms this distribution with a range of $\sim 79^{\circ} \mathrm{N}$ (Axel Heiberg Island, Cana $1 \mathrm{i}, \mathrm{s}$. 1rchepeligo, as Litosphaeridium siphoniphorum subsp.glabrum: Núñez-Betelu (.tai., 1992) to $\sim 6^{\circ} \mathrm{N}$ (Demarera Rise; Eldrett et al., 2017) in the Northern Hemisphere a ${ }^{`} d ~ 12^{\circ} \mathrm{S}$ (DSDP 364: Morgan, 1978; Bathurst Island, Australia: Norvick and Bu^ rer, 1976; northern Madagascar: Herngreen et al., 1982) to $\sim 64^{\circ} \mathrm{S}$ (Antarctic pe `in. $^{\prime}$ ula Keating et al., 1992).

The palaeolatitudal ange of $\sim 73^{\circ} \mathrm{N}$ (Axel Heiberg Island, Canadian Archepeligo, as L. siphoniphorum subsp. glabrum: Núñez-Betelu et al., 1992) to $\sim 0^{\circ} \mathrm{N}$ (Demarera Rise; Eldrett et al., 2017) and $\sim 26^{\circ}$ S (DSDP 364: Morgan, 1978) to $\sim 68^{\circ} \mathrm{S}$ (North island, New Zealand: Crampton et al., 2001). This suggests that the species was widely adapted to Boreal and arid zone environments and was rare from the warmest Tropical waters.

\section{Stratigraphy}

The consensus of available literature suggests that the highest occurrence of Litosphaeridium siphoniphorum occurs in the Lower Turonian (Norvick and Burger, 1976; Decommer, 1982; Foucher, 1982; Robaszynski et al., 1982; Williams and Bujak, 
1985; Herbin et al., 1987; Williams et al., 1993; Caron et al., 1999; Shipboard Scientific Party, 2004; Fensome et al., 2008) worldwide, possibly in the lowermost part of the substage (Habib and Drugg, 1987; Costa and Davey, 1992; Dodsworth, 2000). PostTuronian occurrences have been documented but are considered here to be unreliable due to: (1) very low-resolution sampling (Coniacian: Foucher, 1979; Senonian: Corradini, 1973); (2) comparative rarity (Maastrichtian: Hoek et al., 1996); (3) being based on morphologically questionable specimens (Maastrichtian: Schrank and Ibrahim, 1995); or (4) occurring in samples with clearly reworked species (Coniacian: Foucher, 1979; Early Santonian: Yun, 1981; Campanian: Harker et al. 1990).

Detailed studies suggest that L. siphoniphorum has a hight.+ common occurrence in the Upper Cenomanian (Bujak and Williams, 1978; Foucht 1 J80; Marshall and Batten, 1988; Prössl, 1990), and specifically within the upper $k_{\text {: }}$ ar slinianum Zone in southern England (Dodsworth, 2000; Pearce et al., 2009). B Ju. Ludsworth (2000) and Pearce et al. (2009) found the highest persistent / common scu irrence of L. siphoniphorum to occur in Plenus Marls Bed 6 of southern UK, r r I I Dodsworth (2000) demonstrated to be correlative to Bed 73 in the Cenoma'، 1 - Turonian boundary stratotype at Pueblo (Colorado, USA).

The LAD of L. siphoniphorum is cu nsidered here to lie in the Lower Turonian worldwide, but with a highest per $s i, t \in n t$ / common occurrence in the Upper Cenomanian in the Northern 4, misphere. Plenus Marls Bed 6 occurs mid-way between CTBE event ' $a$ ' and 'b' of Pec 'ct at al. (2009 fig. 3) with an estimated age here of 94.2 Ma. This is slightly your orr L...dn the age derived by Dodsworth and Eldrett (2019), based on an astronor. ' $\mathrm{C}$ '. ' (ubliquity) age model for the Iona-1 core in Texas: $94.56 \mathrm{Ma}$ (top consistent) to 94.2 Ma (top common). However, those authors derived a base Turonian age of 94.12 Ma (cf. Eldrett et al., 2015) rather than the 93.90 Ma age adopted herein, and provisionally by GTS2020 (F. Gradstein pers. comm., 2019).

In the Trunch borehole, where the Upper Cenomanian - Lower Turonian succession is largely barren of palynomorphs, the highest common occurrence of L. siphoniphorum (Lsi) occurs at $504.3 \mathrm{~m}$ around CIE a 1 of Jarvis et al. (2006) (Figs 6, 11) in the Middle Cenomanian (mid-A. rhotomagense Zone; calculated here as 95.68 ( $\pm 0.41 \mathrm{Ma}$ ), and is therefore, not the same event, but is nevertheless a good marker for strata no older than Cenomanian. 


\subsubsection{HO of common Sepispinula ambigua (NW Europe)}

\section{Taxonomy and geographic distribution}

The species Micrhystridium ambiguum was described by Deflandre (1937), and it has subsequently been combined with Cleistosphaeridium, Polysphaeridium, Chlamydophorella, Dapsilidinium, and Gorgonisphaeridium, prior to the current questionable combination with Sepispinula (see Williams et al., 2017). From our inspection of the drawings/images of the holotypes, we consider S. ambigua to be the senior synonym of both S. ancorifera (previously combined with Hystrichosphaeridium and Cleistosphaeridium) and S? huguoniotii (previously com:: ned with Hystrichosphaeridium, subsequently Baltisphaeridium, Cle stos shaeridium, and Chlamydophorella; see Williams et al., 2017), and there ore to be the valid type species of Sepispinula. We therefore, consider it a confident cu mbination. A full taxonomic justification for this will be presented elsewhere.

Sepispinula ambigua (Plate V, 10) appea's o have a bi-hemispherical distribution being recorded from $\sim 74^{\circ} \mathrm{N}$ (eastern Greei, ' ana: Nøhr-Hansen, 1993) to $\sim 11^{\circ} \mathrm{N}$ (Tamil Nada, India: Garg et al., 1988; Khowaja 4'eequzzaman and Jain, 1992) in the Northern Hemisphere and $\sim 13^{\circ} \mathrm{S}$ (offshore nı rth Western Australia: McMinn, 1988) to $\sim 58^{\circ} \mathrm{S}$

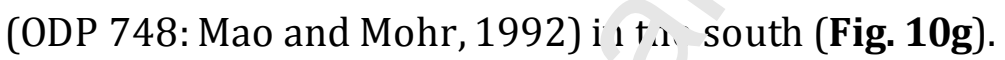

The palaeolatitudinal range ol $\sim 81^{\circ} \mathrm{N}$ (North Slope, Alaska; May and Stein, 1979) to $\sim 10^{\circ} \mathrm{N}$ (Israel: Brenner, 1974 , and $\sim 40^{\circ} \mathrm{S}$ (western Madagascar: Chen, 1978 ) to $\sim 69^{\circ} \mathrm{S}$ (North Island, New Zealan J. W llson, 1989) suggests that it was adapted to arid and Boreal climate zone:

\section{Stratigraphy}

Excluding infrequent records from the Cenozoic (Jiabo, 1978; Sun, 1994; Xu et al., 1997; Richards and Hillier, 2000), the vast majority of published ranges restrict $S$. ambigua to the Cretaceous. Limited long-range quantitative data for S. ambigua exists, but according to Clarke and Verdier (1967; Fig. 12, as Sepispinula huguoniotti that we consider to be a junior synonym of S. ambigua), Tocher (1984), Prössl (1990), Tocher and Jarvis (1996), Dodsworth (2000) and Pearce et al. (2009), S. ambigua appears to be particularly common in the Upper Cenomanian of NW Europe, from where a significant up-section reduction (or absence) into the Turonian occurs. According to Dodsworth 
(2000) and Pearce et al. (2009) the highest common occurrence occurs in the middle / upper M.geslinianum Zone (Plenus Marls Bed 6), estimated here as 94.2 Ma. In the Trunch borehole, Sepispinula ambigua (S?am) is common up to $504.8 \mathrm{~m}$ (Figs 6, 11); being infrequent and rare in the two samples above, in the Middle Cenomanian (mid- $A$. rhotomagense Zone). Its $\mathrm{HO}$ coincides with that of Hapsocysta peridictya, dated above as $95.84( \pm 0.44) \mathrm{Ma}$, although the significance of this is uncertain due to the absence of palynomorphs in the higher Cenomanian. In strata younger than Cenomanian, it only occurs in intervals with the conspicuous reworking of Cenomanian species.

\subsubsection{LAD of Pterodinium crassimuratum (NW Europe)}

\section{Taxonomy and geographic distribution}

Pterodinium crassimuratum (Plate IV, 7) was orig: ally described as Hystrichosphaera crassimurata by Davey and Willia.n. (1966a) from the Cenomanian of southern England. We reject the view of Kjel' st j̈m (1973) and Pavlishina (1990) that it is a junior synonym of $P$ ? pterotum. The $s p$. cies appears to be restricted to the Northern Hemisphere from $\sim 66^{\circ} \mathrm{N}\left(\mathrm{o}_{1}{ }^{-}-\mathrm{r}\right.$ ore mid-Norway, pers. obs.) to $\sim 15^{\circ} \mathrm{N}$ (Senegal: Jain and Millepied, 1975; $\mathrm{L}$ 'it note that their figured specimen is not clearly comparable with the holotype anc is c rly questionably included here), and is distributed through North Amfrica, North Atlantic, Europe (and possibly West Africa, if the Senegalese occurrence is a 'cepted).

The palaeolatitudal ra $\cdot$ e of $\sim 56^{\circ} \mathrm{N}$ (offshore mid-Norway, pers. obs.) to potentially $\sim 8^{\circ} \mathrm{N}$ (Senegal: Jain $\urcorner \mathrm{nc}$ Mi epied, 1975), but with a principally northern mid-latitude distribution (Fig. 10h), : uggests that Pterodinium crassimuratum was adapted to Boreal warm conditions.

\section{Stratigraphy}

Clarke and Verdier (1967) and Foucher (1979) recorded the highest occurrence of Pterodinium crassimuratum in the Lower and Upper Turonian, respectively; and Jain and Millepied (1975) in the Maastrichtian. We have applied a corrected stratigraphy to the records of Clarke and Verdier (1967), and find the highest occurrence to be in the Upper Cenomanian, Ballard Cliff Member (Fig. 12). A similar situation occurs with the stratigraphy used by Marshall (1983) who recorded the highest occurrence in his 
lowermost Turonian sample (M. labiatus Zone); however, the underlying bed is ascribed to the M.geslinianum Zone (thereby missing the uppermost Cenomanian N.juddii Zone), so the reliability of the lowermost Turonian assignment is uncertain. Foucher (1979) also recorded $P$.crassimuratum in the lower Turonian with a significant absence until the uppermost Turonian. Since sea-level fluctuations over the Turonian / Coniacian boundary have been shown to cause significant reworking (e.g. see Fig. 6), the highest record of Foucher (1979) is considered to be of reworked specimens.

The majority of records for the highest occurrence of P.crassimuratum suggest that the LAD occurs in the Late Cenomanian in NW Europe (i.e. Clarke and Verdier, 1967; Davey, 1969; Fauconnier, 1979; Paul et al., 1994; Marshall, 19:2) and specifically in the upper M.geslinianum Zone (uppermost Plenus Marls Bed ¿ P sarce et al., 2009 from southern UK), estimated here as $\sim 94.1 \mathrm{Ma}$. In the Trı $\mathrm{h}$ h $\mathrm{f}$ orehole, the highest occurrence of P. crassimuratus (Pcr) occurs at 50301 , in the Middle Cenomanian (midA. rhotomagense Zone; Figs 6, 11), with a calculatra . oe here of $95.53( \pm 0.39)$ Ma. This does not to coincide with the LAD, but the HC ir $n$ evertheless a good indicator for strata no younger than Cenomanian.

\subsubsection{LAD of Wrevittia cassidata (i' Hemisphere)}

\section{Taxonomy and geographic di « ibution}

Wrevittia cassidata (Plate VI, 12) was originally described as Gonyaulax helicoidea subsp. cassidata by Eisena'k a a Cookson (1960) from the Aptian to Cenomanian of Southern Australia. 't $\mathrm{v}$ 'as , ubsequently raised to species level and transferred to Gonyaulacysta and then o Wrevittia (see Williams et al., 2017). It has been recorded in both hemispheres, from $\sim 79^{\circ} \mathrm{N}$ (Axel Heiberg Island, Canadian Archepeligo: NúñezBetelu et al., 1992) to $\sim 11^{\circ} \mathrm{N}$ (Tamil Nada, India: Khowaja-Ateequzzaman and Jain, 1992), and from $\sim 6^{\circ} \mathrm{S}$ (Papua New Guinea: Davey, 1988) to $\sim 37^{\circ} \mathrm{S}$ (offshore southeast South Australia: Stoian, 2002). As well as being conspicuously absent from the equatorial region, it is also not known from the southern proto-South Atlantic, central USSR, or the NW proto-Pacific margin. Balteș (1967a, b) figured specimens from Romania, but on inspection these appear to be more comparable to Psaligonyaulax deflandrei, emphasizing the morphological similarity of the species. 
The palaeolatitudal range of $\sim 73^{\circ} \mathrm{N}$ (Axel Heiberg Island, Canadian Archepeligo: Núñez-Betelu etal., 1992) to $\sim 23^{\circ} \mathrm{N}$ (DSDP 101: Hollister et al., 1972) and $\sim 26^{\circ}$ S (DSDP 364: Morgan, 1978) to $\sim 66^{\circ} \mathrm{S}$ (offshore southeast South Australia: Stoian, 2002), suggests that Wrevittia cassidata favoured arid and Boreal warm conditions (Fig. 13a).

\section{Stratigraphy}

The highest stratigraphic occurrences of Wrevettia cassidata from Europe are consistently recorded in the Upper Cenomanian (Clarke and Verdier, 1967; Herngreen, 1978; Foucher, 1980; Marshall and Batten, 1988; Louwye, 1992; Dodsworth, 2000, 2004b; Pearce et al., 2009), although FitzPatrick (1995) recc- ded the species from the Turonian of southern England. Yun (1981) recorded W. c. 'ssic ta from the Santonian of Germany, but no range chart was provided and he also figu ed other taxa typical of the Lower Cretaceous or Cenomanian (i.e. Litosphaeridiını siphoniphorum, Oligosphaeridium asterigerum, Polystephanophorus ${ }^{\prime \prime}$ indewolfii, Sepispinula ambigua). The observation of $W$. cassidata by FitzPatricl. 1 .995) comes from Langdon Stairs (Dover, UK), where it is rare and sporadic i. the upper Terebratulinia lata Zone and occasionally common in the Plesiocory. ('ternotaxis) plana Zone (Upper Turonian). The occurrences in the $P$. (S.) plana Zon, are clearly associated with the Lighthouse Down

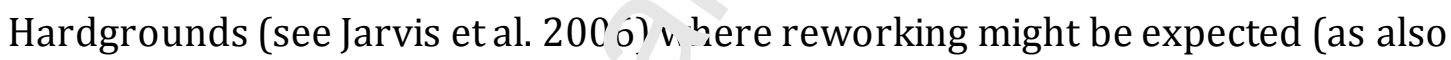
observed at Trunch at the sam ap $_{\mathrm{r}}$ roximate level). FitzPatrick (1995) did not record $W$. cassidata from any of her c'her five coeval sections. We therefore, consider these Turonian observations as $\mathrm{ing}$ based on reworked specimens, and a Late Cenomanian LAD is likely.

Pearce et al. (2009) 'ecorded the HO of W. cassidata in the M.geslinianum Zone (Plenus Marls Bed 6) together with the HO of common S. ambigua which, as discussed above, has an estimated age of 294.2 Ma. Dodsworth (2000) recorded W. cassidata in the stratotype Cenomanian / Turonian boundary interval at Pueblo (Colorado, USA) in a single sample from upper Bed 78 (lower $N$. juddii Zone). Assuming that this is not based on a reworked specimen, it suggests that the HO of persistent $W$. cassidata can be raised to an estimated age here of at least $\sim 94.1 \mathrm{Ma}$. The highest occurrence of $W$. cassidata (Wca) in the Trunch borehole occurs at $504.3 \mathrm{~m}$ (Figs 6, 11), at a break in the carbon isotope gradient between CIEs a1 and a2, with a calculated age here of $95.68( \pm 0.41)$. 


\subsubsection{LAD of Carpodinium obliquicostatum (NW Europe)}

\section{Taxonomy and geographic distribution}

Carpodinium obliquicostatum (Plate I, 6) was described by Cookson and Hughes (1964) from the Upper Albian to Lower Cenomanian of England. It is a particularly distinctive species that can be identified easily from fragments due to its unique ornamentation. It is restricted to the Northern Hemisphere in a narrow latitudinal band from $\sim 66^{\circ} \mathrm{N}$ (offshore mid-Norway, pers. obs.) to $\sim 39^{\circ} \mathrm{N}$ (Colorado, USA; Dodsworth, 2000) and is distributed throughout North America, North Atlantic and Europe. Hedlund and Norris (1968) recorded C. cf. obliquicostatum t. `m Oklahoma, but on inspection, their illustrated specimen is sufficiently dissin ilar to the holotype to be discounted here.

The palaeolatitudinal range of $\sim 56^{\circ} \mathrm{N}$ (offshore $\mathrm{mi}^{-1}-\mathrm{Norway}$, pers. obs.) to $\sim 36^{\circ} \mathrm{N}$ (North Atlantic, ODP 1276; Shipboard Scientific Paı tr 2004) suggests that Carpodinium obliquicostatum was a Boreal warm species (' 19. 13b).

\section{Stratigraphy}

Carpodinium obliquicostatum is typicaıy recorded no higher than the Upper Cenomanian (Davey, 1969; Fouchr.1 1৬30, 1981; Marshall and Batten, 1988; Prössl, 1990; Dodsworth, 2000, 2004a is; Fuarce et al., 2009), an exception being Williams and Bujak (1985) who placed thir evt.nt in the lowermost Turonian. However, it was not stated what this record is hast $d$ on and it is therefore excluded here. Marshall and Batten (1988) recorde ( the HO of $C$.obliquicostatum from the mid- $N$. juddii Zone in Germany. This has subs ?quently been demonstrated by Dodsworth (2000) to have a near synchronous transatlantic HO in Colorado (lower Bed 78, uppermost $M$. geslinianum / S. gracile Zone) and southern UK (single sample from the $N$.juddii Zone). An estimated age here of $\sim 94.0$ Ma for the mid- $N$. juddii Zone is therefore, suggested to be the LAD of the species. The highest occurrence of $C$. obliquicostatum $(\mathrm{Cob})$ in the Trunch borehole at 503.8 m (Middle Cenomanian; A. rhotomagense Zone; Figs 6, 11), calculated here as $95.53( \pm 0.39)$ Ma is therefore earlier than the LAD but is nonetheless a good indicator for strata no younger than Cenomanian.

\subsection{Turonian}


Thirteen species and fourteen events are discussed: (1) LO of Heterosphaeridium difficile (USA and UK); (2) LAD of Hapsocysta dictyota; (3) LAD of Pervosphaeridium cenomaniense; (4) FAD of Canningia glomerata; (5) LO of common S.turonica; (6) LO of common Sentusidinium devonense; (7) FAD and (8) LO of persistent Raetiaedinium truncigerum; (9) FAD of Senoniasphaera filoreticulata; (10) reappearance of Oligosphaeridium pulcherrimum; (11) HO of persistent Cyclonephelium membraniphorum; (12) LAD Stephodinium coronatum; (13) HO of persistent Senoniasphaera turonica; (14) HO of Sentusidinium devonense.

\subsubsection{LO of Heterosphaeridium difficile (southern N. Hemi- 'ohere)}

\section{Taxonomy and geographic distribution}

Heterosphaeridium difficile (Plate II, 12; Plate III, 1) was originally described by Manum and Cookson (1964) as a species of Hystric: $:$ phaeridium from the Cenomanian of Arctic Canada. It has been questionably ( $\mathrm{b} \wedge \mathrm{t}$ ovalidly) combined with Cordosphaeridium, and finally with Heterns, haeridium (see Williams et al., 2017). The species is recorded widely in the Nort. ar $\_$Hemisphere from $\sim 80^{\circ} \mathrm{N}$ (Mount Bridgeman, Canada: Núñez-Betelu et al., 1994) ఒ 33N (northern Pakistan: Köthe et al., 1988 based on reworked specimens), $\mathrm{u}$ itl . Aditional sporadic records from Colombia $\left(\sim 4^{\circ} \mathrm{N}\right.$ : Jaramillo et al., 1994, based on qut tionable specimens), Australia (Bathhurst Island, $\sim 12^{\circ} \mathrm{S}$ : Norvick and Burger 1 ?76), SE Brazilian continental shelf $\left(\sim 26^{\circ} \mathrm{S}\right.$ : Arai, 1994), Antarctic Penninsula ( $\sim 6^{\circ} \mathrm{S}$ : : ieating, 1992$)$ and New Zealand $\left(\sim 72^{\circ} \mathrm{S}\right.$ : Hasegawa et al. 2013).

Excluding sporadic s ecords (and that from Pakistan, since it is uncertain if the study area of Köthe et al., 1988 lay on the northern or southern Tethyan margin), the palaeolatitudal range of $\sim 81^{\circ} \mathrm{N}$ (North Alaska: Witmer et al., 1991) to $\sim 37^{\circ} \mathrm{N}$ (Grand Banks and Scotian Shelf: Barss et al., 1979) suggests that Heterosphaeridium difficile favoured the north Boreal climate zone (Fig. 13c).

\section{Stratigraphy}

The oldest confident placement of the LO of $H$. difficile lies in the Cenomanian from high latitudes (i.e. Australia: Norvick and Burger, 1976; Barents Sea: Bell and Selnes, 1997; Alberta, Canada: Bloch et al., 1999). Both Manum and Cookson (1964) and Davey 
(1969) recorded the species in the Albian but their chronostratigraphies are not adequately demonstrated.

Consistent LOs in the Lower Turonian from more southerly Northern Hemisphere sites are typical (Colorado, USA: Dodsworth, 2000; Czech Republic: Žítt et al., 1997; England: Pearce et al., 2003; North Sea: Costa and Davey, 1992; eastern Greenland: Nøhr-Hansen et al., in press; west Greenland: Pedersen and Nøhr-Hansen, 2014). FitzPatrick (1995) recorded rare H. difficile immediately above the Melbourne Rock beds in Sussex (2 km from the Gun Gardens section studied by Pearce et al., 2009) and by inference therefore, in the Upper Cenomanian N. juddii Zone (cf. Gale et al., 2005). In her text, FitzPatrick (1995) stated that $H$. difficile has a lowest -ccurrence in the Turonian, and excluded the spurious Upper Cenomanian o rence that is documented by her data. In the Trunch borehole, the LO of H.diffi is ( $H$.dif) occurs at $462.00 \mathrm{~m}$ with the reappearance of palynomorphs in the Upper T « nlan (P. (S.) plana Zone), which is a considerable distance above the regional $\mathrm{L} O$.

Dodsworth (2000) recorded a solitary sp er.,n en of $H$. difficile from the Turonian stratotype section at Pueblo (Colorado ũ A, in Bed 95 (Lower Turonian, midWatinoceras coloradoense Zone (within . e Pseudaspidoceras flexuosum Zone of Kennedy et al., 2005), midway betwe $n$ the $N$.juddii and M. nodosoides zones), with an estimated age here of $\sim 93.6 \mathrm{Ma}(\mathbf{l}$ if. $\quad 4)$. The species was found to be persistent in the Middle Turonian (C. woolgari n. nmonite Zone) by Dodsworth and Eldrett 2019. Jarvis et al. (1988a) and Pearce et .l. (2003) recorded the LO of H. difficile stratigraphically slightly higher in the Lowar T.uronian (upper Holywell Member, upper N. nodosoides

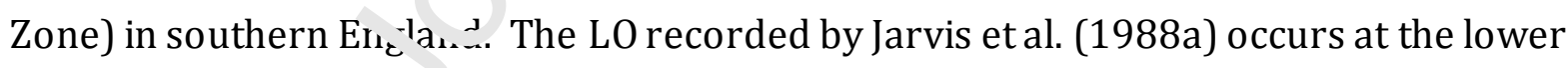
limit of the Lulworth C ${ }^{\text {- }}$ (Jarvis et al., 2006 figs 7, 16); the LO of Pearce et al. (2003) is slightly lower, immediately above CIE c2 (Tu3 of Voigt et al., 2007; Fig. 14), with an estimated age here of $\sim 93.05$ Ma. Heterosphaeridium difficile was not recorded in the Cenomanian / Turonian boundary interval by Pearce et al. (2009) from southern England, but their study did not include the entire M. nodosoides Zone, so the level of the LO of H.difficile was not sampled. 


\subsubsection{LAD of Pervosphaeridium cenomaniense (worldwide)}

\section{Taxonomy and geographic distribution}

This species was originally described as Exochosphaeridium cenomaniense by Norvick in Norvick and Burger (1976) from the Cenomanian of Australia. It is widely reported throughout the Northern Hemisphere south of $\sim 66^{\circ} \mathrm{N}$ (offshore mid-Norway, pers. obs.) to $\sim 9^{\circ} \mathrm{N}$ (western Venezuela; Helenes et al., 1998) and from $\sim 12^{\circ} \mathrm{S}$ (Bathurst Island, Australia: Norvick and Burger 1976; northern Madagascar: Herngreen et al., 1982 ) to $\sim 71^{\circ} \mathrm{S}$ (ODP 962: Masure et al., 1998). It is distributed through North and South America, the North Atlantic and northern South Atlan _. Europe, North, West and south-eastern Africa, south-western Asia and northern Aı stra ia.

The palaeolatitudal range of $\sim 63^{\circ} \mathrm{N}$ (Alberta, Cana la; $\mathrm{L}$ eckie et al., 1992) to $\sim 4^{\circ} \mathrm{N}$ (western Venezuela; Helenes et al., 1998) and $28^{\circ}{ }^{\circ}$ ( ₹ ₹mpos Basin, offshore Brazil; Arai and Masure, 1997) to $\sim 68^{\circ} \mathrm{S}$ (ODP 962; Masur _ _al., 1998), suggests that Pervosphaeridium cenomaniense (Plate IV, 3) $\mathrm{w}_{\boldsymbol{\Lambda}}$ s insensitive to climate variation but absent from high latitudes (Fig. 13d).

\section{Stratigraphy}

The LAD of $P$. cenomaniense ar $\mathrm{p}^{2}$ ar $s$ to occur no higher than Lower Turonian (Norvick and Burger, 1976; Hel _.. as _ c al., 1998; Lamolda and Mao, 1999), and specifically according to Pear :e $\epsilon$ al. (2009) within the lower M. nodosoides Zone, between the Compton Pehble ' Yarl and Gun Gardens Marl 1 in southern England, with an estimated age here ( f 3.4 Ma (Fig. 14).

In the German Konı $d 101$ borehole, Prössl (1990) indicated that the highest occurrence of $P$. cenomaniense lay in the lower Middle Turonian based on its occurrence in a single sample (otherwise with a top of persistent occurrences in the uppermost Cenomanian). However, in the absence of a micro- or macrofossil calibration, his chronostratigraphic divisions are based on sonic and resistance logs (but it was not demonstrated how). It is therefore possible that this Turonian record is based on reworked specimen(s), so cannot confidently be used to raise the LAD up into the Middle Turonian. The HO of P. cenomaniense (PCe) at $507.9 \mathrm{~m}$ in the Lower Cenomanian (M. dixonii Zone; Figs 6, 11) in the Trunch borehole is therefore considerably below the suggested LAD, with a calculated age here of $97.01( \pm 0.51)$ Ma. 


\subsubsection{FAD of Canningia glomerata (N. Hemisphere)}

\section{Taxonomy and geographic distribution}

Clarke and Verdier (1967) described Canningia glomerata (as Senoniasphaera rotundata; Plate I, 4) from the Santonian - Campanian of southern England. It was transferred to Canningia by Fensome et al. (2019) and assigned the new species name on becoming a junior homonym. It has been recorded throughout North America, North Atlantic, eastern Greenland, Europe and south-western Asia from $\sim 73^{\circ} \mathrm{N}$ (Kara Shelf, Russia: Lebedeva, 2006) to $\sim 26^{\circ} \mathrm{N}$ (DSDP 138; Diederix et a:., 1972). Given its wide temperate tolerance, it is somewhat surprising that $C$. glo verc $t a$ is not recorded widespread in the Southern Hemisphere. According tc Doı ling (1992) and Wood and Askin (1992) it occurs on Antarctica. However, onlv V'od and Askin (1992) provided an illustrated specimen and this appears to more cin sly resemble, S. edenensis Marshall 1990, and therefore, both Southern Hemisph r r records are excluded here.

The palaeolatitudal range of $\sim 69^{\circ} \mathrm{N}$ ( $\mathrm{K}_{\mathrm{c}}$ a Snelf, Russia; Lebedeva, 2006) to $\sim 10^{\circ} \mathrm{N}$ (Israel; Eshet et al., 1994; Hoek et al., ^ フo J; Fig. 13e) suggests the species was adapted to Boreal warm and arid climate bei's.

\section{Stratigraphy}

In a study of multiple we ${ }^{1} s$ t $>m$ the Norwegian Sea, Smelror et al. (1994) recorded C. glomerata from a samp'e w hin the Upper Albian - Lower Cenomanian. However, it appears to be an isolat $d c_{c}$ se (and potentially caved), with the next record occurring well within the Turonia:. No Illustrated evidence was provided and in the light of available evidence this record is also excluded. Williams and Brideaux (1975) recorded C. glomerata from a single sample dated as Cenomanian - Turonian but which lacks stratigraphic resolution. Williams (1977) recorded rare C. glomerata from the eastern Atlantic Ocean from an interval dated as no younger than Middle - Upper Cenomanian, based on the presence of $D$. alatum. However, D. alatum is now considered to have a LAD in the mid-Early Campanian (Section 7.5.3.), furthermore C.glomerata was found to co-occur with L. siphoniphorum (Section 7.1.6.) that appears to have a LAD in the Early Turonian. Azéma et al. (1981) also recorded rare Senoniasphaera cf. rotundata in 
a single sample from the ?Lower Cenomanian of western France but this is excluded here due to its questionable identification.

According to Foucher (1981), Jarvis et al. (1988a) and Pearce et al. (2003) the LO of C. glomerata lies in the lowest Middle Turonian; both Jarvis et al (1988a) and Pearce et al. (2003) record the event between CIEs d1 and d2. However, this LO can be extended down into the Lower Turonian based on data from Robaszynski et al. (1982), Tocher and Jarvis (1994b, 1995) and Lamolda and Mao (1999). Tocher and Jarvis (1994b) provided a dataset for the intra-Lower Turonian in western France, but the precise chronostratigraphic position of the LO of C. glomerata cannot be determined because the position of the substage boundaries is not known. It is $\sin ^{-1} \mathrm{~T}$-7rly difficult to place the LO reported by Tocher and Jarvis (1995) since the top of $t_{1}$. I ower Turonian was not reached in their study.

In northern Spain, Lamolda and Mao (1999) r'cu a aed the LO of Canningia glomerata $\sim 2 \mathrm{~m}$ above the LO of Mammites nodos riac ? $\sim 4 \mathrm{~m}$ above the LO of Quadrum gartneri and $\sim 18 \mathrm{~m}$ below the LO of Helvetot, u ı ina helvetica. Robaszynski et al. (1982) recorded approximately the sar « or nortional distribution of the LOs of $C$. glomerata, Q.gartneri and H. helvetica $w$ : hin the M.nodosoides Zone in western France, indicating a similar sequence of Lowe - Turonian events. FitzPatrick (1995) recorded the LO of C.glomerata $\sim 8 \mathrm{~m}$ above + a€ cop of the Ballard Cliff member at Eastbourne (southern England), $2 \mathrm{~km}$ fro. $\urcorner$ the CTBE study of Pearce et al. (2009). Recent observations from Dodswo, th a nd Eldrett (2019) from Pueblo (Colorado USA), place the LO in the GSSP sectir - $\mathrm{L}=\mathrm{d} 113$ (within the M. nodosoides Zone). This suggests that the LO lies close to thr r. zutinus / M. nodosoides zonal boundary (cf. Gale et al., 2005.) Therefore, until a mor : precise LO of the C.glomerata $(\mathrm{Cgl})$ is available, the FAD is taken at the base of the M. nodosoides Zone, with an age of 93.35 Ma (Fig. 14).

In the Trunch borehole, C. glomerata has a LO at $459.0 \mathrm{~m}$ (P. (S.) plana Zone, Upper Turonian) with an age calculated here as 90.96 ( \pm 0.5 ) Ma (Figs 6, 14), and although stratigraphically higher than expected due to the presence of an extended predominantly barren interval, it is nonetheless a useful indicator for strata no older than Turonian. 


\subsubsection{LO of common Senoniasphaera turonica (NW Europe)}

\section{Taxonomy and geographic distribution}

Senoniasphaera turonica was originally described as Craspedodinium turonicum by Prössl (1990) later combined with Senoniasphaera by Pearce et al. (2011) who also considered it as the senior synonym of Senoniasphaera rotundata subsp. alveolata Pearce et al (2003). Pearce et al. (2011) suggested that it is likely that some specimens of $S$. rotundata (now Canningia glomerata) recorded in the Turonian may be misidentified S. turonica (Plate V, 6-7).

Senoniasphaera turonica is recognised from $\sim 55^{\circ} \mathrm{N}$ (nor hern North Sea, pers. obs.; Bornholm, Denmark; Schiøler, 1992 as Senoniasphaera? $s_{1}^{\prime}$. a) to $\sim 30^{\circ} \mathrm{N}$ (Texas, Dodsworth, 2016); through Denmark (Schiøler, 1992), sou hern England (Lignum, 2008; Pearce et al., 2009), France (Lignum, 2008) ana Termany (Prössl, 1990; Lignum, 2008) and Colorado (USA; Fig. 13f).

The palaeolatitudal range of $\sim 46^{\circ} \mathrm{N}$ (nortile $n$ North Sea, pers. obs.; Bornholm, Denmark, Schiøler, 1992) to $\sim 32^{\circ} \mathrm{N}$ (Gr Tes 's, vodsworth, 2016) suggests that $S$. turonica was restricted to the souther. $\mathrm{P}$ jreal warm climate zone.

\section{Stratigraphy}

Although S. turonica has be _. r. r.orded in the Cenomanian (Lignum, 2008), it becomes particularly commc il in :he Lower Turonian (Pearce et al., 2003, 2009; Pearce, 2011), with the lowest co $m m$. $n$ occurrence (Pearce et al., 2009; Olde et al., 2015) at the base of the M. nodosoid 's ' $\mathrm{n}$ ne $(93.35 \mathrm{Ma}$; Figs 6, 14). This is consistent with the findings of Dodsworth a nd Eldrett (2019) who record the lowest occurrence at Pueblo (Colorado, USA) in the GSSP section, Bed 116 (M. nodosoides Zone). The lowest common occurrence of S. turonica is therefore, suggested to lie in the Lower Turonian in NW Europe, and possibly the Northern Hemisphere. In the Trunch borehole, S. turonica (Stu) has a LCO at $465.0 \mathrm{~m}$ (Plesiocorys (S.) plana Zone, lower Upper Turonian) with an age calculated here as 91.01 ( \pm 0.52 ) Ma; Fig. 14). The higher LCO is attributable to the presence of an extended 'barren' interval, but it is nonetheless a useful indicator for strata no older than Turonian. 


\subsubsection{LAD of Hapsocysta dictyota (N. Hemisphere)}

\section{Taxonomy and geographic distribution}

Hapsocysta dictyota (Plate II, 10) was first recorded by Davey (1979) from the Albian of the Bay of Biscay, Atlantic Ocean. We concur with Masure and Vrielynck (2009) that it is restricted to the Northern Hemisphere, and recognise a range of south of $\sim 66^{\circ} \mathrm{N}$ (offshore mid-Norway, pers. obs.) to $\sim 30^{\circ} \mathrm{N}$ (northeast Libya; Unwins and Batten, 1989), through North America, North Atlantic, Europe, and North Africa. The palaeolatitudal range of $\sim 56^{\circ} \mathrm{N}$ (offshore mid-Norway, pers. obs.) to $\sim 12^{\circ} \mathrm{N}$ (northeast Libya; Unwins and Batten, 1989), suggests that H. dictyota u. $_{\text {c }}$ adapted to arid and southern Boreal warm climate belts (Fig. 13g).

\section{Stratigraphy}

Hapsocysta dictyota is typically recorded fror: the Albian and Cenomanian (Davey, 1979; Below, 1984; Prössl, 1990), but the highnci occurrences reported by Marshall and Batten (1988; who provided a range of Upp «r ¿ ¿.1omanian to Lower Turonian) and Dodsworth (2000), and from persona' ob ervations in the Norwegian Sea, suggest that the LAD occurs in the lowermost Turonian. Tocher (1984) recorded H.dictyota from the uppermost Turonian of southe... England, but from a sample that also contained Litosphaeridium siphoniphorum ' $V_{t}$ _onsider this to be the result of reworking, with his highest in situ occurrence th^ 1 lying in the uppermost Cenomanian.

Dodsworth (2000) rerorciad the HO of $H$. dictyota from the Turonian stratotype section at Pueblo (Colo adı) from Bed 102 (lowermost M. nodosoides Zone) and slightly stratigraphically lower i om southern UK in his highest sample from the lower $W$. coloradoense Zone. Dodsworth's observations from Pueblo are confirmed in Dodsworth and Eldrett (2019), where no stratigraphically higher samples yielded any further specimens of $H$. dictyota. Therefore, the LAD of $H$. dictyota is suggested to lie in the Early Turonian in the Northern Hemisphere. Due to the lack of age control on the age of Bed 102 at Pueblo, we approximate the LAD of $H$. dictyota to an estimated age of $\sim 93.3$ Ma (Fig. 14). In the Trunch borehole, the HO of H. dictyota (Hdic) occurs at $504.3 \mathrm{~m}$ in the Middle Cenomanian (mid-A. rhotomagense Zone; Figs 6, 11), lower than expected due to the existence of the largely barren interval above, with a calculated age of 95.68 ( \pm 0.41) Ma. 


\subsubsection{LO of common Sentusidinium devonense (NW Europe)}

\section{Taxonomy and geographic distribution}

Sentusidinium devonense (Plate V, 8) was originally recorded by Tocher (1984) in his $\mathrm{PhD}$ thesis as Sentusidinium sp. b, from the Lower Turonian of multiple sites in the western Anglo-Paris Basin. It was formally published by Pearce (2018) and is currently only known from NW Europe between $\sim 53^{\circ} \mathrm{N}$ (Trunch borehole, this study) and $\sim 45^{\circ} \mathrm{N}$ (southeast France: Lignum, 2008), with additional records from southern England (Tocher and Jarvis, 1987; Jarvis et al., 1988a; Fitzpatrick, 19, 5: Pearce et al., 2009), western France (Tocher, 1984) and northern Germany (L onu n, 2008).

The palaeolatitudal range of $\sim 43^{\circ} \mathrm{N}$ (this study; $\mathrm{NV}^{\prime} \mathrm{Ge}$ 'many: Lignum, 2008 ) to $\sim 36^{\circ} \mathrm{N}$ (southeast France: Lignum, 2008) suggests thai the taxon was a southern Boreal warm species (Fig. 13h).

\section{Stratigraphy}

Pearce et al. (2009) recorded the '.0 r i S. devonense (as Sentusidinium sp. b of Tocher and Jarvis, 1987) in the mid-M. gesïnianum Zone (Upper Cenomanian, Plenus Marls Bed 2/3) of southern Englar ì Oiner documented LOs occur in the Lower Turonian (Tocher, 1984; Toche : nú jarvis, 1987; Jarvis et al., 1988a; FitzPatrick, 1995; Pearce, 2000). However, a sic nitıant increase in relative abundance has been noted in the lower Middle Turonian (F izPatrick, 1995; Pearce, 2000) with an acme in the Middle Turonian. The positior of $i$ ine increase reported by Pearce (2000) occurs at the midpoint between CIEs d 1 a nd d 2 of Jarvis et al. (2006) with an estimated age of $~ 92.8 \mathrm{Ma}$ (Figs 6, 14). The relative abundance increase noted by FitzPatrick (1995) occurs slightly higher around New Pit Marl 1 (above the Low-woollgari CIE). The lowest common occurrence of $S$. devonense (Sde; observed at $460 \mathrm{~m}$ depth in the Upper Turonian Plesiocorys (S.) plana Zone at Trunch) therefore, would be expected to occur within the 'barren' interval at Trunch and cannot be tested. 


\subsubsection{FAD and LO of persistent Raetiaedinium truncigerum (N. Hemisphere)}

\section{Taxonomy and geographic distribution}

Raetiaedinium truncigerum (Plate IV, 8) was originally described as Hystrichosphaeridium truncigerum by Deflandre (1937) and has been subjected to numerous taxonomic revisions with combinations to Cordosphaeridium, Exochosphaeridium, Florentinia, Litosphaeridium, Pervosphaeridium, Tityrosphaeridium, and finally Raetiaedinium (see Williams et al., 2017). It is restricted to the Northern Hemisphere from $\sim 66^{\circ} \mathrm{N}$ (offshore mid-Norway, pers. obs.) to $\sim 30^{\circ} \mathrm{N}$ (central Texas, USA: Harker et al., 1990; northern Egypt: Schrank and Ibrah.., 1995 ) and is distributed through North America, North Atlantic, Europe, North Afr ca a 1d south-western Asia (Fig. 15a). Davey (1978, plate 4 figs 12 -13) recordec a tá xon as Exochosphaeridium truncigerum from DSDP 361, offshore south-western if frica; however, it possesses significantly shorter processes than the holotype $o_{1}^{-D}$. cruncigerum and is excluded here. The palaeolatitudal range of $\sim 56^{\circ} \mathrm{N}$ (offshore $\mathrm{m}$. $d$-Norway, pers. obs.) to $\sim 10^{\circ} \mathrm{N}$ (Israel: Eshet et al., 1992, 1994; Hoek et al., 1996) s 'ggests that $R$. truncigerum favoured southern warm Boreal and arid climaı $b$ sts.

\section{Stratigraphy}

Despite records of R.trunci, „ ' $u_{\ldots .}$ in the Late Jurassic (Riley and Sarjeant, 1972) and Lower Cretaceous (Below, 1932 , the majority of detailed stratigraphic studies suggest the LO occurs in the Upper Cr taceous and particularly in the Coniacian (Bujak and Williams, 1978; Kirsch, 19: 1; Schiøler, 1992; Stover et al., 1996; Herngreen et al., 1996), or Upper Turonian (Fou sher, 1974; Wilkinson and Halliwell, 1980; Williams and Bujak, 1985) in the Northern Hemisphere.

According to Prössl (1990) the LO occurs in the uppermost Middle Turonian of the Konrad 101 borehole (Germany); however, his chronostratigraphy is based on unspecified microfauna and elogs, so it is not known how accurate this placement is. Based on the first occurrence of $R$. truncigerum lying 20\% from the top of the Middle Turonian (as estimated from his range chart) an age of $\sim 91.6 \mathrm{Ma}$ is possible for Prössl (1990), assuming the chronostratigraphy of the Konrad 101 borehole is accurate. Recent work by Olde et al. (2015) has identified the LO of $R$. truncigerum in the midMiddle Turonian $\sim 15 \mathrm{~m}$ below the Glynde CIE in borehole material from the Czech 
Republic, followed by a conspicuous absence from immediately above the Glynde Event up to a reappearance towards the top of the Upper Turonian, mid-way between the Hitch Wood and Navigation CIEs. The lower occurrence has an estimated age here of 91.9 Ma (Fig. 14) based on a $\delta^{13} \mathrm{C}_{\text {carb }}$ correlation and supports the findings of Prössl (1990).

Raetiaedinium truncigerum (Rtr) has consistent distribution through the Trunch borehole, being present in over 78\% of all samples studied (although rare) with a LO at $467.00 \mathrm{~m}$ (above the reappearance of dinocysts in the Turonian) in the lowermost Upper Turonian ( $P$. (S.) plana Zone). This event falls immediately above the h1 CIE with a calculated age of $91.04( \pm 0.53) \mathrm{Ma}$ and is taken as the lowect $\mu$ ?rsistent occurrence (Figs 6, 14).

\subsubsection{FAD of Senoniasphaera filoreticulata ( $N^{\prime} / v \in$ Hope)}

\section{Taxonomy and geographic distribution}

This species was originally described $\mathrm{f}_{\mathrm{t}}>\mathrm{m}$ the Campanian of the Netherlands as Canningia filoreticulata by Slimani $(1 \zeta\urcorner^{4}$, transferred to Cyclonephelium by Prince et al. (1999) and finally Senoniasphaera L.r Fensome et al. 2019. Prince et al. (1999) considered it likely that this speci s $n$.y have previously been misidentified by others as Cyclonephelium membraniph oruı? due to its morphological similarity. Additional records from Belgium (Sliman: 1994), eastern Czech Republic (Skupien and Mohammed, 2008) and so. thr rn England (Pearce et al., 2003) restrict the species to NW Europe with a r $n^{\supset}$ of $\sim 53-50^{\circ} \mathrm{N}$. A tight palaeolatitudal spread of $\sim 43^{\circ} \mathrm{N}$ (Trunch borehole, this $\mathrm{s}^{1} \mathrm{udy}$ ) to $\sim 41^{\circ} \mathrm{N}$ (eastern Czech Republic: Skupien and Mohammed, 2008) so far suggests that this species has a narrow ecological range in the southern Boreal warm climate belt (Fig. 15b).

\section{Stratigraphy}

According to Prince et al. (2008) the LO of S. filoreticulata (Plate V, 4) occurs in the Lower Coniacian (but note that they did not study the Turonian). The LO of $S$. filoreticulata (Sfi) in the Trunch borehole at $439.0 \mathrm{~m}$ (Figs 6, 14) extends the northern limit to $\sim 47^{\circ} \mathrm{N}$ and the FAD into the latest Late Turonian ( $P$. (S.) plana Zone). This event occurs at CIE i3 that has a calculated age of $90.16( \pm 0.5)$ Ma (Fig. 14). Limited 
published information restricts the usefulness of the species; however, the FAD is suggested to be a potentially useful indicator for the Late Turonian.

\subsubsection{Reappearance of Oligosphaeridium pulcherrimum (NW Europe)}

\section{Taxonomy and geographic distribution}

This species was originally described as Hystrichosphaeridium pulcherrimum from the Albian of Australia. It has subsequently been recorded from $\sim 82^{\circ} \mathrm{N}$ (north Ellesmere Island, Canadian Archepeligo: Nøhr-Hansen and McIntyre, 1998) to $\sim 64^{\circ} \mathrm{S}$ (Antarctic peninsula: Palamarczuk et al., 1984; Dettmann ar.' Thomson, 1987; Olivero and Palamarczuk, 1987; Wrenn and Hart, 1988; Askin et ć.., 1:91; Cocozza and Clarke, 1992; Dolding, 1992; Keating, 1992; Keating et al., 199 '; Di ane, 1996; Pirrie et al., 1997; Riding et al., 1998).

The palaeolatitudal range of $\sim 81^{\circ} \mathrm{N}$ (north Alas.'n. Witmer et al., 1981; Haga, 1990; Kimyai, 1992) to $\sim 74^{\circ} \mathrm{N}(\mathrm{New}$ Zealand: Raine, 1 377) indicates that 0 . pulcherrimum (Plate IV, 1) was a truly cosmopolitan snec: es (Fig. 15c).

\section{Stratigraphy}

The inception of Oligosphaerid i $n$ pulcherrimum is well described from the uppermost Jurassic (Williams a a' Bujak, 1985; Riding and Thomas, 1988; Poulsen, 1993; Gitmez and Ertug, 199(1). 1: their study of the Turonian and Coniacian of southern England, Pearce et a.. (2003) recorded rare specimens of 0 . pulcherrimum in the Middle Turonian, $\mathrm{n}$ th c persistent occurrence, potentially in the Upper Turonian (questionable, due to e $\mathrm{e}^{\mathrm{r}}$ reme condensation), and a significant increase in relative numbers through the Coniacian. Data from Schiøler (1992) supports the reappearance of the species in the uppermost Turonian. Robaszynski et al. (1982) recorded sporadic occurrences of rare specimens through the Turo nian that increase to frequent in the Upper Turonian. Clarke and Verdier (1967) recorded very low numbers through the Turonian and Coniacian of southern England but showed an increase of relative numbers of 0 . pulcherrimum in the Lower Coniacian, which is supported by the data of Prince et al. (2008). Further evidence for a Coniacian reappearance is given by Williams and Brideaux (1975) who studied eight Upper Cretaceous cores from the western North Atlantic, and found O. pulcherrimum to have a range of Coniacian to Lower Santonian. A 
Lower Coniacian reappearance may also be evident from the data presented by Kirsch (1991) and Nøhr-Hansen (1996) but is questionable due to a lack of stratigraphic control.

A temporary disappearance of the taxon has been reported by Prössl (1990) who recorded persistent 0 . pulcherrimum from the Upper Hauterivian to the Upper Albian of Germany, but from where there a prolonged absence up to the Upper Turonian. This is corroborated by Lignum (2008) who only recorded rare and sporadic occurrences of $O$. pulcherrimum through the Cenomanian and Lower Turonian of southern England, France and Germany. The absence of Oligosphaeridium pulcherrimum may be limited to NW Europe since it has been recorded continuously through i: Turonian in northern Egypt (Foad and Lashin, 2012). In the Trunch borehole, th ? I J of O. pulcherrimum $(\mathrm{Opu})$ occurs at $438.0 \mathrm{~m}$ in the uppermost Turonian (?. 's ' plana Zone; Figs 6, 14) and is suggested to mark the regional reappearance of $\rho t$ : sistently occurring specimens. This event occurs immediately above CIE i3 with ? ca'rulated age here of $90.12( \pm 0.49)$ Ma (Fig. 14).

\subsubsection{HO of persistent Cyclonepheliu. ' membraniphorum (NW Europe)}

\section{Taxonomy and geographic distriv tiun}

Cyclonephelium membranix. ho :'m was described by Deflandre and Cookson (1955) from the Albian - Cenomania.. of Western Australia, and was subsequently associated with Maghrebinia and Cau.ori yinium (see Williams et al., 2017) prior to be returned to Cyclonephelium by $\mathrm{F}$ эn: $\mathrm{om}$, et al. (20190. It is known from $\sim 74^{\circ} \mathrm{N}$ (eastern Greenland: Nøhr-Hansen, in press) $1 \mathrm{~J} \sim 30^{\circ} \mathrm{N}$ (northern Egypt: Schrank and Ibrahim, 1995) in the Northern Hemisphere and from $\sim 12^{\circ} \mathrm{S}$ (Bathurst Island, Australia: Norvick and Burger, 1976 ) to $\sim 64^{\circ} \mathrm{S}$ (Antarctic peninsula,: Olivero and Palamarczuk, 1987).

The palaeolatitudal range of $\sim 81^{\circ} \mathrm{N}$ (northern Alaska: Witmer et al., 1981 ) to $\sim 12^{\circ} \mathrm{N}$ (northern Egypt: Schrank and Ibrahim, 1995) and $\sim 31^{\circ} S$ (southeast Brazilian continental shelf: Arai, 1994) and $\sim 68^{\circ} \mathrm{S}$ (northeast South Island, New Zealand: Wilson, 1982; Wilson and Morgans, 1989, both as questionable identifications) indicates that this species favoured Boreal warm climate belts in both hemispheres (Fig. 15d). Schiøler and Wilson (1998) recorded Cyclonephelium cf. membraniphorum farther to the south on the South Island of New Zealand, but on reviewing their figured specimen, we 
agree with the implication that the specimen is sufficiently dissimilar to the holotype to be excluded.

\section{Stratigraphy}

The highest occurrence of Cyclonephelium membraniphorum (Plate II, 2) has been recorded from the Coniacian - Santonian of France (Foucher, 1979; based on a presence / absence data only, no distribution information given), lower Middle Santonian (herein, although immediately above a 15 m interval of reworking), Santonian - Campanian interval of Arctic Canada (Ioannides, 1986; presence only), Campanian of the USA (although rare and sporadic, Harker et al., 1990), and "post-_ "etaceous" according to Foucher (1983).

The majority of records suggest that the LAD occui s clc se to or at the top of the Coniacian (Foucher, 1983, assuming his post-Cretarev ' $s$ records are reworked; Williams and Bujak, 1985; Mohr and Gee, 1992; Scı: $\left.x^{\top} . \mathrm{er}, 1992\right)$. Foucher (1971b; 1975a; 1976a, c as Cyclonephelium cf. membr in phorum; 1980), Costa and Davey (1992) and Prince et al. (2008) placed the HO at thi top of the Turonian, which is coincident

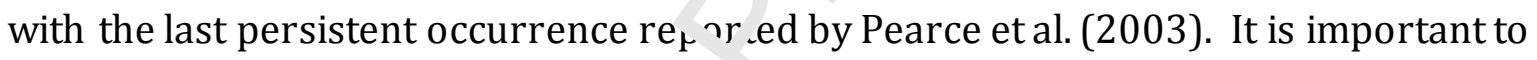
note that in a study of the Coniacian - Maastrichtian in Germany, Kirsch (1991) did not record C.membraniphorum, supp $\mathrm{r}^{\dagger}{ }_{\mathrm{H}} \mathrm{g}$ the case that it is rare and sporadic postTuronian. A conspicuous abser ce if C. membraniphorum may also have a wider geographical significance, wh ${ }^{\text {re }}$ it was found to be absent above the Turonian in the USA by Scott et al. (2018) and Dodsworth and Eldrett (2019).

Therefore, the $\mathrm{L} A D$ of ( . membraniphorum is suggested to lie in the Upper Coniacian, but with a hig hest persistent occurrence in the Upper Turonian, both events in the Northern Hemisphere. In the Trunch borehole, C. membraniphorum (Cme) is persistently recorded in productive samples (although generally rare) through the Cenomanian to Upper Turonian (to 433.3 m, P. (S.) plana Zone; Figs 6, 14), being notably sporadic above. This highest persistent occurrence is calculated here as 89.92 $( \pm 0.47) \mathrm{Ma}$. 


\subsubsection{LAD of Stephodinium coronatum (N. Hemisphere)}

\section{Taxonomy and geographic distribution}

Deflandre (1936a) described Stephodinium coronatum from the 'Senonian' (location uncertain), and with the exception of records from Australia (as Stephodinium cf. coronatum, Bathurst Island: Norvick and Burger, 1976; South Queensland: Burger, 1988; questionably from southwest Western Australia: Cookson and Eisenack, 1969) and the south-eastern Brazilian continental shelf (Arai, 1994) the species is dominantly a Northern Hemisphere form. The identification by Norvick and Burger (1976) may also be problematic as they considered $S$. coronatum to be $\mathrm{s}_{j}$ - onymous with $S$. australicum and S. europaeicum. The currently accepted v ew 'Singh, 1983) is that $S$. australicum is not a junior synonym of S. coronatum.

Stephodinium coronatum has been recorded frnm $-77^{\circ} \mathrm{N}$ (Graham Island, Canadian archipelago, as Stephodinium europaicum: Manum anr. Cookson, 1964) and $\sim 74^{\circ} \mathrm{N}$ (eastern Greenland: Nøhr-Hansen, in press) t $ノ-24^{\circ} \mathrm{N}$ (DSDP 535, southeastern Gulf of Mexico: Riley and Fenton, 1984), and is dis ibuted through North America, North Atlantic, Europe, North Africa and Asia.

The palaeolatitudal range of $\sim \mathrm{o}^{1} \mathrm{~N}$ (northern Alaska: Witmer et al., 1981) to $\sim 19^{\circ} \mathrm{N}$ (Tunisia: Caron et al., 1999) sugge st, , hat Stephodinium coronatum (Plate VI, 7) principally favoured north Bor ะal varm to Boreal tropical climate belts (Fig. 15e).

\section{Stratigraphy}

Bujak and Williams (1:78) and Williams and Bujak (1985) referred to the highest occurrence of $S$. corona $1 m$ in the Santonian but provided no distribution data, so it is not possible to determine how persistently specimens were recorded in that range. Ioannides (1986) also recorded S. coronatum in the Santonian to ?Maastrichtian but in samples with prominent reworking of taxa. The bulk of available data suggests that $S$. coronatum has a highest occurrence (at least in the Northern Hemisphere) in the uppermost Turonian (i.e. Williams and Brideaux, 1975; Foucher, 1975a, 1976a; Marshall, 1983; Tocher, 1984; Costa and Davey, 1992; Williams et al., 1993) or confidently to the top of the Turonian, and questionably in the Lower Coniacian or Lower Santonian (Foucher 1979, 1983 - but the latter possibly attributed to $S$ ? pellucidum). Schiøler (1992) recorded the highest occurrence of S. coronatum 
immediately below the highest common occurrence of his Senoniasphaera? sp. a (synonymous with Senoniasphaera turonica; Section 7.2.4.) taken here as a marker for the Upper Turonian (Section 7.2.12.). Prince et al. (2008) recorded S. coronatum in the Lower and lowest Middle Coniacian of southern UK, but on re-examination their material appears to more closely resemble Disphaeria macropyla.

Therefore, the LAD of $S$. coronatum is suggested to lie in the uppermost Turonian in the Northern Hemisphere. The highest occurrence of S. coronatum $(\mathrm{Sco})$ in the Trunch borehole occurs at $432.4 \mathrm{~m}$ in the uppermost Turonian (P. (S.) plana Zone; Figs 6, 14), and is therefore, taken to correspond to the LAD. The event occurs in the lower part of the Navigation CIE with a calculated age here of $89.88( \pm 0.47$, Ma.

\subsubsection{LO of persistent Senoniasphaera turonica ( $N^{\prime}$ F.drope)}

Section 7.2.4. provides a brief taxonomic and ge, $\mathrm{g}_{1}$ aphic discussion for Senoniasphaera turonica.

\section{Stratigraphy}

With the exception of Prince et al. ? 75 , as Senoniasphaera rotundata subsp. alveolata), the highest persistent oc.'irrence of $S$. turonica has been reported in the Upper Turonian (in Germany: Prö is', 1990; and southern England: Pearce et al., 2003). Marshall (1983) recorded a veı y si.nilar form from Germany as Senoniasphaera sp. a that also has a highest occurr nce in the Upper Turonian, which was subsequently listed as Canningia sp. a by Mars: $:$ all and Batten (1988) and considered to be synonymous with S. turonica by Poai ee $f$ ial. (2011). Prince et al. (2008) consistently recorded the species from the Upper ' ioniacian well into the Santonian (but presented no Turonian data), and although Pearce et al. (2003) recorded it into the Lower Coniacian, they found it to be only persistently present into the lowermost Coniacian (they included no Upper Coniacian data).

It appears likely that two intervals of persistent occurrence exist in NW Europe, with tops at the Turonian/Coniacian boundary and the top Middle Santonian. In the Trunch borehole, Senoniasphaera turonica (Stu) is persistently recorded to $432.2 \mathrm{~m}$, and has a highest occurrence at $414.0 \mathrm{~m}$ in the upper Lower Coniacian (M. cortestudinarium Zone). Therefore, only the lower of the two top persistent occurrences described appears to be present in the southern North Sea basin, particularly as the species was 
not recorded by Kirsch (1991) in his study of the Coniacian - Maastrichtian chalks of Germany. At Trunch, the event occurs within the lower part of the Navigation CIE at the Turonian/Coniacian boundary with a calculated age here of 89.87 ( \pm 0.46$)$ Ma (Fig. 14).

\subsubsection{LAD of Sentusidinium devonense (NW Europe)}

Section 7.2.6. provides a brief taxonomic and geographic discussion for Sentusidinium devonense.

\section{Stratigraphy}

The highest occurrence of Sentusidinium devonense has : sen recorded from the Banterwick Barn borehole in southern England and from he 'i runch borehole (Pearce 2018; herein. In his PhD thesis, Pearce (2000) consiste ntly recorded it as relatively common to abundant through the Turonian at Banter. ick Barn (data was not made available in Pearce et al., 2003) with a highest occu. ${ }^{\text {rr }}$,nce questionably in the Upper Turonian (the Upper Turonian is extremely $c^{\prime} n^{\prime}$ ensed). In the Trunch borehole, the highest occurrence occurs at $430.0 \mathrm{~m}$ at the Turonian/Coniacian boundary (lower $M$. cortestudinarium Zone; Fig. 14), whici, is consistent with the results of FitzPatrick (1995) from southern and southeas 'England. The apparent lack of any species of Sentusidinium above the Turoniar ir $\mathrm{h}$ a Chalk of NW Europe (the genus was not

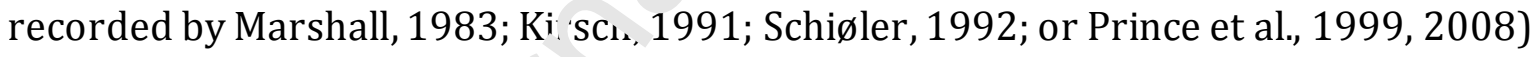
confirms that Sentusidinium avonense (Sde) has its LAD in the Turonian. The event at Trunch occurs at the maxı. 'urı negative excursion of the Navigation CIE at the Turonian/Coniaciar. ho ind ary with a calculated age here of $89.76( \pm 0.43)$ Ma (Fig. 14).

\subsection{Coniacian}

Five events in the Trunch borehole are discussed: (1) LO of persistent Heterosphaeridium verdieri; (2) HO of persistent Callaiosphaeridium asymmetricum; (3) LO of frequent Senoniasphaera filoreticulata; (4) FAD of Spinidinium echinoideum, (5) LO of persistent Raphidodinium fucatum. 


\subsubsection{LO of persistent Heterosphaeridium verdieri (NW Europe)}

\section{Taxonomy and geographic distribution}

Heterosphaeridium verdieri was described by Yun (1981) from the Lower Santonian of Germany. It is restricted to the Northern Hemisphere from $\sim 80^{\circ} \mathrm{N}$ (Mount Bridgeman, Ellesmere Island, Canadian Archipelago, as H. cf. verdieri: Núñez-Betelu et al., 1994) or confidently from $\sim 66^{\circ} \mathrm{N}$ (offshore mid-Norway, pers. obs.) to $\sim 49^{\circ} \mathrm{N}$ (SE Germany: Kirsch, 1991) with additional records from southern England (Pearce et al., 2003).

The palaeolatitudinal range of $\sim 70^{\circ} \mathrm{N}$ (Mount Bridgema.., Ellesmere Island, Canadian Archepeligo, Núñez-Betelu et al., 1994) or 56. J (o fshore mid-Norway, pers. obs.) to $\sim 40^{\circ} \mathrm{N}$ (SE Germany: Kirsch, 1991) suggests th th $h$ terosphaeridium verdieri (Plate III, 2) was confined to southern North Boreal v ?rm environments (Fig. 15f).

\section{Stratigraphy}

Pearce et al. (2003) recorded the lowes o o ".rrence of Heterosphaeridium verdieri in the Middle Turonian but specimens rer ain rare until a significant influx in the Middle Coniacian (mid-White Fall CIE). Prince et al. (2008) also found the species to be rare in the Lower Coniacian, with more $\mathrm{p}_{\iota_{1}}$ istunt occurrences or increased relative numbers in the Middle Coniacian. In the ${ }^{2}$ Mind borehole the $\mathrm{LO}$ is recorded at $406.0 \mathrm{~m}$ immediately above the East $r$ iff CIE in the mid-Middle Coniacian (M. coranguinum Zone, from where it is persistently $r$.corded; Figs 6, 16). This is consistent with the findings of Prince et al. (2008) a nd `earce et al. (2003). The lowest persistent occurrence of $H$. verdieri (Hve) therefort, appears to be a good marker for the intra-Middle Coniacian in NW Europe, with a calculated age here of $87.99( \pm 0.52)$ Ma (Fig. 16).

\subsubsection{HO of persistent Callaiosphaeridium asymmetricum (NW Europe)}

\section{Taxonomy and geographic distribution}

Callaiosphaeridium asymmetricum (Plate I, 3) was originally described as a species of Hystrichosphaeridium by Deflandre and Courtville (1939) from the 'Senonian' of France. It has been associated with the now invalid Hexasphaera (see Williams et al., 2017). The species has a present-day distribution from $\sim 82^{\circ} \mathrm{N}$ (north Ellesmere Island, Canadian Archipelago: Nøhr-Hansen and McIntyre, 1998) to $\sim 64^{\circ} \mathrm{S}$ (Antarctic 
peninsula: Dettmann and Thomson, 1987; Keating, 1992; Keating et al., 1992). It is well distributed through North and southern South America, North Atlantic, NW Europe, North Africa and Australia, and sparsely recorded in Asia, southern South America, southern Africa, and Antarctic Peninsula.

Given the palaeogeography of the Early Coniacian(Fig. 15g), the species is notably absent from the equatorial region with a distribution of $\sim 81^{\circ} \mathrm{N}$ (north Alaska, USA: May and Stein, 1979; Timmcke, 1981; Witmer et al., 1981; Kimyai, 2000) to $\sim 11^{\circ} \mathrm{N}$ (Israel: Eshet et al., 1992), and $\sim 32^{\circ} \mathrm{S}$ (Papua: Fraser et al., 1993) to $\sim 71^{\circ} \mathrm{S}$ (northeast South Island, New Zealand: Schiøler and Wilson, 1998), which suggests that C.asymmetricum was restricted to the Boreal warm and arid climate zones. Tht record of the species as ?Callaiosphaeridium asymmetricum by Lawal (1982) from ''F. Jigeria is excluded as we find the illustrated specimen too dissimilar to the hol $s$, ne.

\section{Stratigraphy}

Callaiosphaeridium asymmetricum has be $\mathrm{n}$ recorded from the Maastrichtian (Kjellström, 1973) but occurs sporadicallv ind in low numbers, and is possibly based on reworked specimens. The bulk of avain $r$. e literature suggests that the highest occurrence of $C$. asymmetricum occurs in the Campanian, where it is typically rare and sporadic in the upper part (Robas sy .. 'ti et al., 1985; Habib and Miller, 1989; Kirsch, 1991; Nøhr-Hansen, 1996), but the species is recorded consistently in the Lower Campanian (Foucher, 1975a, : 976a, c, 1979; Aurisano 1989; Mao and Mohr, 1992;

Prince, 1997; Schiøler ana 'Vil ;on, 1998; Fensome et al., 2008). Numerous stratigraphic studies indicate tha' th $\mathrm{HC}$ occurs at the Lower/Upper Campanian boundary (Williams and Bujak, 1985, in the r id-Campanian; Costa and Davey, 1992; Williams et al., 1993; Stover et al., 1996; Williams et al., 2004; pers. obs. from the Norwegian Sea). Fensome et al. (2008) provided an age of 79.8 Ma (Gradstein et al. 2004, Middle Campanian; out of range for the present study) for the LAD of C. asymmetricum.

In the Trunch borehole, the highest occurrence of C. asymmetricum (Cas) occurs at $350.0 \mathrm{~m}$ in the Middle Santonian (M. coranguinum Zone; Figs 6, 18), which does not coincide with the LAD of the species, and is taken as a local event. This event occurs immediately above the $\mathrm{m} 2 \mathrm{CIE}$ and is calculated here as $85.3( \pm 0.55)$ Ma. The highest persistent occurrence occurs at $397.0 \mathrm{~m}$ at the j1 CIE in the Middle Coniacian ( $M$. coranguinum Zone). This is consistent with the results of Foucher (1975a, 1976a, 1979) 
from the Paris Basin, who recorded a conspicuous absence of $C$. asymmetricum through the Santonian prior to its reappearance in the Lower Campanian. The HO of persistent C. asymmetricum in the Middle Coniacian is interpreted to represent a local event with a calculated age here of $87.32( \pm 0.54)$ Ma (Fig. 16).

\subsubsection{LO of frequent Senonasphaera filoreticulata (NW Europe)}

A brief taxonomic and geographic discussion of Senonasphaera filoreticulata is presented in Section 7.2.8.

\section{Stratigraphy}

At Trunch a minor influx (lowest frequent occurrenct) of 3. filoreticulata (Sfi) occurs at $388.0 \mathrm{~m}$ in the mid-Middle Coniacian (M. corı ngu inum Zone; Figs 6, 16) immediately below the Kingsdown CIE, with a calculas age here of $86.76( \pm 0.55)$ Ma. This appears to be broadly synchronous with data n East Kent (SE England; Prince et al., 2008). Farther to the south, on the Isle of ' $v$ sht, Prince et al. (2008) showed that this influx occurs slightly lower (but still m: 1 -Middle Coniacian) below the j1 CIE and immediately above the Anvil Hardgro nr's, with an estimated age here of 87.23 Ma (Fig. 16). Pearce et al. (2003) recorded 'ne LO of S. filoreticulata in the Banterwick Barn borehole (Berkshire) at a positior $b^{\prime}: \iota$ "een the Light Point and East Cliff CIEs (Lower Coniacian) but crucially found le ela ive numbers to be low. The top of the Banterwick Barn core lies within the nega ${ }^{-i v} \delta^{13} \mathrm{C}_{\text {carb }}$ excursion above the White Fall CIE but below the j1 CIE, and therefore b ${ }^{\prime} o^{\prime} r$ the influx noted at Trunch and on the Isle of Wight.

\subsubsection{FAD of Spinidini ım echinoideum (N. Hemisphere)}

\section{Taxonomy and geographic distribution}

This small peridinioid species was originally described as Deflandrea echinoidea by Cookson and Eisenack (1960) from the Santonian and Campanian of Australia. It has subsequently been associated with Vozzhennikovia prior to Spinidinium (see Williams et al., 2017). It has a near-cosmopolitan distribution questionably from $\sim 75^{\circ} \mathrm{N}$ (Canadian Arctic Archipeligo, Byam Martin Island: Kerr, 1974) or confidently from $\sim 73^{\circ} \mathrm{N}$ (Kara Sea shelf: Lebedeva, 2006) to $\sim 64^{\circ} \mathrm{S}$ (Antarctic peninsula: Keating, 1992) but is absent 
from $\sim 4^{\circ} \mathrm{N}$ (Colombia: Dueñas-Jimenez, 1990) to $\sim 13^{\circ} \mathrm{S}$ (offshore north Western Australia: McMinn, 1988).

The palaeolatitudinal range of $\sim 82^{\circ} \mathrm{N}$ (northern Alaska: Witmer et al., 1981) to questionably $\sim 69^{\circ} \mathrm{S}$ (Chatham Islands: Wilson, 1976; Mildenhall, 1977) or $\sim 67^{\circ} \mathrm{S}$ (northeast South Island, New Zealand: Schiøler and Wilson, 1998; Rongaglia et al., 1999; southeast Tasmania: Harris et al., 1999) suggests that S. echinoideum (Plate VI, 1) favoured a broad range of Boreal warm environments in both hemispheres. (Fig. 15h).

\section{Stratigraphy}

Numerous studies have recorded S. echinoideum from tr.: upper Lower Cretaceous (e.g. Davey, 1970, but which more resemble Chichaouadin um restitum; and Ogg 1994, but which are infrequently present). Questionable Tur snía n first occurrences were reported by Foucher (1979; as Spinidinium cf. echinnicivum), Azéma et al. (1981; but the chronostratigraphy is poorly constrained) and Cou.tivat (1993; the species is recorded from only one sample and no illustration was $\rho$ r jvided) and these records are excluded here.

The majority of records suggest this 't' ne lowest occurrence of S.echinoideum lies in the Coniacian (Fauconnier, 1984; V:lliams and Bujak, 1985; Kirsch, 1991 as Spinidinium cf. echinoideum; Schiøler, 1992; N h. Uansen, 1994, 1996). Dam et al. (1998, following the zonation scheme of Nøhr-Hans $\backsim n, 1996)$ recorded S. echinoideum in their Upper Turonian - Lower Coniacian s terval of the Umiivik-1 borehole from West Greenland. This interval is characteris $>\mathrm{d} l \mathrm{y}$ the consistent presence of Raphidodinium fucatum (Section 7.3.5.) anc' as ? re ;ult may be considered to be no older than Middle Coniacian based on our stratigrapł ical review. It should be mentioned that Pedersen and NøhrHansen (2014) state that the ammonite zone index fossil Scaphites preventricosus was found to be in situ above specimens of S. echinoideum in the Umiivik-1 borehole, suggesting the FAD may occur at least as early as Early Coniacian. Azéma et al. (1981) recorded a bloom of S. echinoideum in their 'Senonian' section from western France, between the top of the Turonian and the FO of S. protrusa (Section 7.4.8.). This corresponds to middle of the Coniacian - mid-Middle Santonian interval, and lies potentially, therefore, in the Upper Coniacian.

The FAD of S. echinoideum is consequently suggested to lie in the Coniacian in the Northern Hemisphere, and until the material from the Umiivik-1 borehole be 
investigated further, we choose to accept an Early Coniacian FAD for the species (following Pedersen and Nøhr-Hansen, 2014). The first occurrence of S. echinoideum $(\mathrm{Sec})$ in the Trunch borehole occurs at $393.0 \mathrm{~m}$ in the mid-Middle Coniacian (M. coranguinum Zone; Figs 6, 16), and appears to be synchronous with that recorded by Prince et al. (2008; although it is extremely rare) in southern England. It is notable that neither Marshall (1983) nor Tocher (1984) recorded S. echinoideum from the Turonian to Lower Coniacian (their section tops) of Germany and France, respectively. Therefore, the lowest occurrence at Trunch (and other localities in Europe) is taken as a useful event for the species that occurs midway between the $\mathrm{j} 1$ and $\mathrm{j} 2$ CIEs, with a calculated age here of 87.05 ( \pm 0.54) Ma (Fig. 16).

\subsubsection{LO of persistent Raphidodinium fucatum (N W F.v rope)}

\section{Taxonomy and geographic distribution}

Raphidodinium fucatum was described fr $\mathrm{s}$ the (presumed) 'Senonian' of France by Deflandre (1936b). It has subsequently hei $n$ found to be restricted to the Northern Hemisphere from $\sim 71^{\circ} \mathrm{N}$ (west Greenı $\eta_{\wedge}$ : Nøhr-Hansen, 1996; Dam et al., 1998, 2000) to $\sim 36^{\circ} \mathrm{N}$ (northern Iran: Moradin and Allameh, 2010) and is distributed through western Greenland, NW Europe a id $\iota$ ` Middle East.

The palaeolatitudinal range ol $\quad-59^{\circ} \mathrm{N}$ (west Greenland: Nøhr-Hansen, 1996; Dam et al., 1998, 2000) to $\sim 30^{\circ} \mathrm{N}$ (no * thern Iran: Moradin and Allameh, 2010 as Raphidodinium facatum [SIC]) indicates thr.t $F$. fucatum was predominantly a North Boreal warm climate taxon (Fig. $17 \mathbf{7}$;

\section{Stratigraphy}

There appears to be a latitudinal temperate affect controlling the distribution of the species. In Europe, according to Foucher (1975a, 1976b, 1979) the lowest occurrence of R. fucatum (Plate IV, 9) occurs at the top of the Turonian in France, although he did not provide detailed range data. That being said, Tocher (1984) did not record the species in his study of French Albian to Lower Coniacian chalks. The species is also unrecorded from the Santonian of southern England and only rare specimens occur in the Lower Campanian (Prince, 1997). Furthermore, a notable absence of R. fucatum is apparent in Germany since it was not recorded by either Marshall (1983) or Kirsch 
(1991) in their Cenomanian - Coniacian and Coniacian - Maastrichtian studies, respectively.

In the higher latitudes, Costa and Davey (1992) indicated that in the North Sea the lowest occurrence occurs in the mid-Middle Turonian. As pointed out by Nøhr-Hansen (in press; see references therein), other middle Turonian lowest occurrences of $R$. fucatum in the middle Turonian have been recorded from the North Sea area, Norwegian Sea and west Greenland, while an upper Coniacian LO was reported by Nøhr-Hansen (2012) from the Sorgenfri Formation at Kangerlussuaq, eastern Greenland.

In the Trunch borehole, the lowest occurrence of $R$. fucatu. $n(R f u)$ occurs at $392.0 \mathrm{~m}$ in the upper Middle Coniacian (M. coranguinum Zone; Figs 6. 26), and it continues to be reasonably persistently into the Campanian. Therefo $: t$, alt 1 ough the FAD of $R$. fucatum possibly lies in the Middle Turonian, the lowest pe. sı. ${ }^{+}$ent occurrence is suggested to lie in the Coniacian in NW Europe. The event in the Tru.rh borehole corresponds to the maximum negative $\delta^{13} \mathrm{C}_{\text {carb }}$ excursion betwe $\eta, 1$ and j2 CIEs, with a calculated age here of 86.99 ( \pm 0.54) Ma (Fig. 16).

\subsection{Santonian}

Twenty-five lowest (LO) and hi h sst occurrence (HO) events in the Trunch borehole are discussed to ass - their relationship to first (FAD) and last appearance datum (LAD) levels. These a re, in stratigraphic order (base up): (1) FAD of Spiniferites ramosus subsp. maeand ${ }_{\text {:, }}^{\text {? }}$ r....IS; (2) LO of common Spinidinium echinoideum; (3)

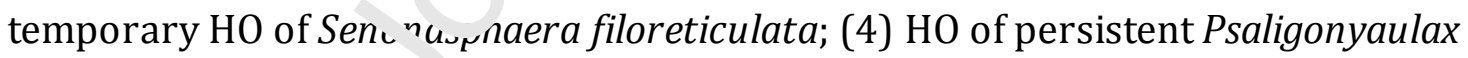
deflandrei; (5) LO of Ku.ildinium rigidum; (6) FAD of Chatangiella manumii; (7) FAD of Senoniasphaera protrusa; (8) FAD of Cannosphaeropsis utinensis; (9) LAD of Spiniferites porosus; (10) LO of Chatangiella eminens; (11) HO of Renidinium rigidum; (12) FAD of Pervosphaeridium intervelum; (13) reappearance of Coronifera striolata; (14) FAD of Dimidium striatum; (15) LO of Spiniferites jarvisii; (16) FAD of Odontochitina diducta; (17) LO of common Chatangiella eminens; (18) LO of Trimuridinium whitenessense; (19) LO of Odontochitina porifera; (20) LAD of Heterosphaeridium difficile; (21) HCO of Chatangiella eminens; (22) LO of Cordosphaeridium catherineae; (23) LAD of Scriniodinium campanula; (24) FAD of Rhynchodiniopsis saliorum; (25) LAD of Kleithriasphaeridium readei. 


\subsubsection{FAD of Spiniferites ramosus subsp. maeandriformis (NW Europe)}

\section{Taxonomy and geographic distribution}

Corradini (1973) described Spiniferites ramosus var. maendriformis (Plate VI, 5) from the 'Senonian' of northwest Italy $\sim 46^{\circ} \mathrm{N}$. Additional published records are sparse and come from offshore mid-Norway (the most northerly site at $\sim 66^{\circ} \mathrm{N}$, pers. obs.) and the Norwegian North Sea (pers. obs.), Denmark and southern Sweden (Hultberg, 1985), Belgium and the Netherlands (Slimani, 2001a), and southern England (Prince et al., 1999).

The palaeolatitudinal range of $\sim 56^{\circ} \mathrm{N}$ (offshore mid-N oru ay, pers. obs.) to $\sim 30^{\circ} \mathrm{N}$ (northwest Italy: Corradini, 1973) restricts the species pril cipally to the north European warm Boreal area (Fig. 17b).

\section{Stratigraphy}

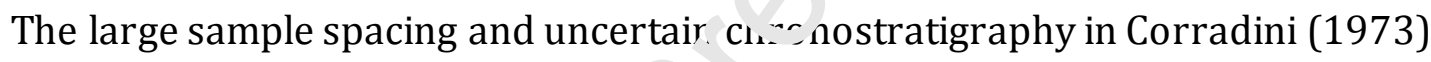
renders a stratigraphic comparison in ora tical, but according to Prince (1997) the lowest occurrence of S. r. maeandriformis lias in the Upper Santonian at CIE o3. An excellent record of S. r. maendrifor . ' ${ }^{\circ}$ ( $\mathrm{Lrm}$ ) at Trunch extends the inception of the species to the lowermost Santo in $n$... here is it first recorded at $371.0 \mathrm{~m}(M$. coranguinum Zone; Figs 6, 14,16). At Trunch, the LO lies in the upper part of the Michel Dean CIE calculated he $\bullet$ as 86.1 ( \pm 0.52 ) Ma and therefore appears to be a marker for the earliest jan onian; this is suggested to be the FAD of the species. The first persistent occurre $e_{\Perp}$ ce lies in the Lower Campanian, dated here as $84.00( \pm 0.50) \mathrm{Ma}$ (Figs 18, 21).

\subsubsection{LO of common Spindinium echinoideum (NW Europe)}

Section 7.3.4. provides a brief taxonomic and geographic discussion for Spindinium echinoideum.

\section{Stratigraphy}

The FAD of S. echinoideum ( $\mathrm{Sec}$ ) likely occurs in the mid-Middle Coniacian. However, a significant influx of the species is recorded in the Trunch borehole with a lowest common occurrence at $370.0 \mathrm{~m}$ in the Lower Santonian (M.coranguinum Zone; 
Figs 6, 16, 18). A similar influx is apparent in the Paris Basin (Foucher 1976b, 1979) and the proto-Atlantic Basin (Azéma et al., 1981 - although less convincing due to a lack of stratigraphic control). Interestingly, Foucher (1976b,1979) recorded the highest occurrence of frequent specimens across the Santonian/Campanian boundary (SCB), with very rare specimens in the Upper Santonian. This same distribution is evident in the Trunch borehole, with a second influx of frequent to common S. echinoideum across the SCB.

Dam et al. (1998) recorded S. echinoideum in the Coniacian of West Greenland. These occur relatively abundantly (although no values were stated) in their Upper Turonian - Lower Coniacian interval (but which is considerea here to be no lower than upper Middle Coniacian; Section 7.3.4). This may be an $e_{4}$ 'iir alent event, but the precise correlation is uncertain. The LO of common $S . t^{-h i}$. oideum in the Trunch borehole lies immediately above the Michel Dean $f_{1 \mathrm{~L}} \mathrm{v}_{1}$ ich a calculated age here of 86.06 $( \pm 0.52)$ Ma (Fig. 18).

\subsubsection{Temporary HO of Senoniasphr . 1 , J:'oreticulata (NW Europe)}

A brief taxonomic and geographic $a_{\text {. }}$ - sussion of Senoniasphaera filoreticulata is provided in Section 7.3.3.

\section{Stratigraphy}

Senoniasphaera filoreticu.'،ta was originally described from the Upper Campanian (lower B. mucronata Zone; of selgium by Slimani (1994), with a highest occurrence in the upper Upper Cån ، nia I (B. mucronata minor Zone). A similar distribution has been observed in southern Er gland (Iain Prince, pers. comm.), where it is often abundant to occasionally superabundant in the Upper Campanian. Upper Campanian material was not included in the present study. However, the temporary disappearance of persistently occurring S. filoreticulata (Sfi) within the Lower Santonian (Prince et al., 1999, 2008) is also apparent in the Trunch borehole at $368.0 \mathrm{~m}$ (Figs 6, 16, 18), and is suggested to be a locally significant event. In Kent and at Culver Cliff (Prince et al., 2008) the temporary disappearance of consistent $S$ filoreticulata occurs within the interval of the Michel Dean CIE (basal Santonian). At Trunch, the event falls slightly higher, midway between the Michel Dean and Bedwell CIEs, with a calculated age here of 85.99 ( \pm 0.52) Ma (Fig. 18). 


\subsubsection{HO of persistent Psaligonyaulax deflandrei (NW Europe?)}

\section{Taxonomy and geographic distribution}

Psaligonyaulax deflandrei was described by Sarjeant (1966) from the Cenomanian of southeast England; it has also been associated with Gonyaulacysta (see Williams et al., 2017). We follow Clarke et al. (1968) by considering it a senior synonym of Gonyaulacysta extensa Clarke and Verdier 1967). It is recorded from both hemispheres from $\sim 66^{\circ} \mathrm{N}$ (offshore mid-Norway, pers. obs.) to $\sim 64^{\circ} \mathrm{S}$ (Antarctic peninsula: Keating et al., 1992) but is conspicuously absent from equatorial areas , $\circ \mathrm{mm} \sim 16^{\circ} \mathrm{N}$ (Andra Pradesh, India: Mehrotra et al., 2002) to $12^{\circ}$ S (South Atli ntic DSDP 364: Morgan, 1978; Bathurst Island, Australa: Norvick and Burger, 1 176. It is distributed through North America, North Atlantic, NW Europe, West Afric s south and southeastern Asia, south Indian Ocean, Australia and Antarctica.

The palaeolatitudinal range of $\sim 56^{\circ} \mathrm{N}$ (of sr ure mid-Norway, pers. obs.) to $\sim 20^{\circ} \mathrm{N}$ (southwest Morocco: Below, 1981) and 2: 'S (south Atlantic, DSDP 364: Morgan, 1978 ) to $\sim 64^{\circ} \mathrm{S}$ (offshore southeast Sc ' $\mathrm{t}^{\prime}$. Australia: Stoian, 2002) suggests that Psaligonyaulax deflandrei (Plate IV, Ћ) favoured areas of arid to Boreal warm climate (Fig. 17c).

\section{Stratigraphy}

Highest occurrences $\cap \mathrm{f} P$. Ieflandrei have been recorded in the Santonian (Stoian, 2002) or Campanian (F oucier, 1975a, 1976a, 1979) but are typically sporadic or questionable. The highı st occurrence or highest persistent occurrence has also been drawn at the top of the Coniacian (Foucher, 1976a; Costa and Davey, 1992) in NW Europe, or mid-Coniacian (Williams and Brideaux, 1975, as G. extensa) or lowermost Santonian (Foucher, 1975a; 1979 - questionable specimens were recorded in the basal Lower Campanian) in the Northern Hemisphere.

In the Trunch borehole, the highest occurrence of P. deflandrei (Pde) occurs at 328.0 $m$ in the Upper Santonian (U. socialis Zone), but the highest occurrence of persistent specimens occurs at $367.0 \mathrm{~m}$ in the low Lower Santonian (M. coranguinum Zone; Figs 6, 16, 18), which is comparable with the HO recorded by Foucher (1975a, 1979). However, it was not recorded by Kirsch $(1991)$ or Prince et al. $(1999,2008)$ from the 
Coniacian to Campanian of Germany and southern England, respectively, which apparently limits the usefulness of the event. In the Trunch borehole, the highest persistent occurrence occurs immediately below the Bedwell CIE with a calculated age here of $85.95( \pm 0.52)$ Ma (Fig. 18).

\subsubsection{LO of Renidinium rigidum (NW Europe?)}

\section{Taxonomy and geographic distribution}

Renidinium rigidum (Plate IV, 10 - 11) was relatively recently described by Prince et al. (1999) from the Middle Santonian of southern Englanc. It was subsequently recorded from four additional southeastern England sites by t rince et al. (2008) where the LO was extended into the Lower Santonian. Recor ' $s$ or this species outside of the English Chalk are unknown and as such, it currentlv $h_{c}$ s a range of $\sim 53-50^{\circ} \mathrm{N}$, with a palaeolatitudinal range of $\sim 43-41^{\circ} \mathrm{N}$ (Fig. 17d).

\section{Stratigraphy}

At Culver Cliff and in East Kent ( $\mathrm{P}^{\prime}$,nc , et al., 2008) and in the Trunch borehole (at $361.0 \mathrm{~m}$ ) the LO of $R$. rigidum (Rri) nccurs consistently at the 11 CIE in the upper Lower Santonian (Micraster coranguinum $\overrightarrow{\llcorner}$ רn ; Fig. 6) with a calculated age here of $85.77( \pm$ 0.52) Ma (Fig. 18).

\subsubsection{FAD of Chatangie'la n xnumii (N. Hemisphere)}

\section{Taxonomy and geos ${ }^{*} a_{r}^{h} ; c$ distribution}

Chatangiella manuınii (Plate I, 9) was originally described as Cooksoniella manumii by Vozzhennikova (1967) from the Upper Cretaceous of Russia. It appears to be restricted to the Northern Hemisphere, from $\sim 76^{\circ} \mathrm{N}$ (Taymyr, Russia: Khomentovskii et al., 1999) to northern $\sim 30^{\circ} \mathrm{N}$ (northern Egypt: Abdel-Kireem et al., 1996; Schrank and Ibrahim, 1995) and distributed through North America, North Atlantic, Europe (questionably in France), North Africa and Asia.

The palaeolatitudinal range of $\sim 75^{\circ} \mathrm{N}$ (Taymyr, Russia: Khomentovskii et al., 1999) to $\sim 12^{\circ} \mathrm{N}$ (northern Egypt: Abdel-Kireem et al., 1996; Schrank and Ibrahim, 1995) suggests that $C$. manumii was principally a north Boreal warm to Boreal tropical species (Fig. 17e). 


\section{Stratigraphy}

The lowest stratigraphic level at which C. manumii has been recorded is Santonian (Herbin et al., 1987; Schrank and Ibrahim, 1995), although Campanian LOs are typical (Aurisano, 1989; Lentin and Vozzhennikova, 1990; Ilyina et al., 1994; Lebedeva, 2006). The LO of C. manumii ( $\mathrm{Cma}$ ) in the Trunch borehole occurs at $351.0 \mathrm{~m}$ in the Middle Santonian (M. coranguinum Zone; Figs 6, 18), but it is not persistently recorded until $279.0 \mathrm{~m}$ (where the relative abundance also increases) in the Lower Campanian $(O$. pillula Zone). The lowest occurrence at Trunch is taken as the FAD of the species and together with the LO of persistent specimens, are both take 1 as potentially useful bioevents in the Northern Hemisphere. The FAD occurs at $a_{11} 2 \mathrm{CIE}$ and the LO of persistent specimens above the pillula CIE with calcula+__ ages of $85.37( \pm 0.54)$ Ma and 83.48 ( \pm 0.5 ) Ma, respectively (Fig. 18).

\subsubsection{FAD of Cannosphaeropsis utinensis (N. 'ten.: sphere)}

\section{Taxonomy and geographic distribution}

Cannosphaeropsis utinensis (Plate I, ') was described by Wetzel (1933) from the 'Senonian' of the southern Baltic reg» $\eta$. Numerous Miocene occurrences have been recorded but these are now attribut 20 to C. passio de Verteuil and Norris 1996. Williams and Bujak (1985), Wi' 'iams et al. (1993) and Williams et al. (2004) place the LAD of $C$. utinensis in the Ma`sı 'ichtian. Therefore, Cenozoic occurrences (if not clearly reworked) have been omit几 d here. Cannosphaeropsis utinensis is recorded from $\sim 57^{\circ} \mathrm{N}$

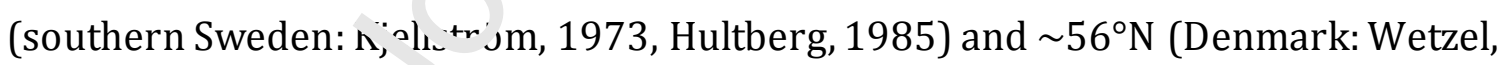
1933, 1940; Wilson, 1? 1 ; Hansen, 1979a, b; Hultberg, 1985) to $4^{\circ}{ }^{\circ} \mathrm{S}$ (Santa Cruz, Argentinia: Barreda and Palamarczuk, 2000).

The palaeolatitudinal range of $\sim 52^{\circ} \mathrm{N}$ (Hokkaido Island, Japan: Kurita and Obuse, 1994 ) to $\sim 59^{\circ} \mathrm{S}$ (southwest Western Australia: Cookson and Eisenack, 1962) suggests that C. utinensis was a low-latitude Boreal warm to tropical taxon (Fig. 17f).

\section{Stratigraphy}

The majority of records clearly suggest a LO of $C$. utinensis in the Santonian, either somewhere in the Middle Santonian (Foucher 1975a, b, 1976a, b, 1979, 1983), midMiddle Santonian based on the contemporaneous appearance of Senoniasphaera 
protrusa (Azéma et al., 1981), or Upper Santonian (Williams and Bujak, 1985; Stover et al., 1996; Prince et al., 1999). The FAD of $C$. utinensis is therefore suggested to lie in the Middle Santonian in the Northern Hemisphere with an estimated age of 85.25 Ma (i.e. coincident with that of $S$. protrusa, see Section 7.4.8.). The lowest occurrence of $C$. utinensis (Cut) provided by Prince et al. (1999) occurs between CIEs o1 and o2 (Figs 6, 18) and is estimated to have an age of $\sim 84.72 \mathrm{Ma}$. In the Trunch borehole the LO occurs at $310.0 \mathrm{~m}$ in the Upper Santonian (M. testudinarius Zone) with a calculated age of 84.30 $( \pm 0.44)$ Ma (Fig. 18).

\subsubsection{FAD of Senoniasphaera protrusa (N. Hemisphere)}

\section{Taxonomy and geographic distribution}

Senoniasphaera protrusa (Plate V, 5) was descrihc t by Clarke and Verdier (1967) from the Santonian of southern England. Prince (1 $20 \%$ ) noted that not all specimens of S. protrusa possess antapical horns on the en ${ }^{0} 0^{\prime}$ yst (such specimens are now $S$. congrensa (Prince et al., 2008) Fensome et: I., 2u19), as in the type species. In order to find new criteria to separate these spe ie, Prince et al. (1999) made detailed measurements of the autocysts ana 'ctocysts of S. protrusa and Canningia glomerata (as $S$. rotundata) and emended the $\mathrm{sp} \pm \mathrm{C}^{\mathrm{i}}$ - descriptions accordingly. Therefore, prior to 1999 and depending on the spєcie concept used, these species names may not have been assigned correctly in the 'iterature. For example, in Williams and Brideaux (1975 plate 1 fig. 9) their specimı $n$ or S. protrusa appears to be Canningia glomerata, while their $S$. rotundata ( $\mathrm{F}^{\mathrm{l}} \mathrm{zt}, 1 \mathrm{f} \mathrm{g}$. 10) appears to be $S$. congrensa following the emended descriptions of Prince et al. (1999).

Senoniasphaera protrusa is typically recorded from the Northern Hemisphere from $\sim 71^{\circ} \mathrm{N}$ (west Greenland: as Senoniasphaera aff. protrusa, Nøhr-Hansen, 1996; UstYenisei region, Russia: Lebedeva, 2006) to $\sim 32^{\circ} \mathrm{N}$ (northern Texas, USA: Harker et al., 1990) and is distributed through North America, North Atlantic, Europe, North Africa and western Asia. Two conspicuously isolated additional occurrences have been recorded from the offshore Ivory Coast $\left(\sim 4^{\circ} \mathrm{N}\right.$ : Tea-Yassia et al., 1999) and the Antarctic peninsula ( $\sim 64^{\circ} \mathrm{S}$ : Dolding, 1992; no specimen was illustrated). Excluding the isolated occurrences, the palaeolatitudinal range of $\sim 68^{\circ} \mathrm{N}$ (Ust-Yenisei region, Russia: Lebedeva 
2006) to $\sim 21^{\circ} \mathrm{N}$ (northeast Algeria: Foucher et al., 1994) suggests the species is principally a southern to mid- Boreal warm climate taxon (Fig. 17g).

\section{Stratigraphy}

The stratigraphically oldest records of S. protrusa occur from the Turonian (Williams, 1975; Bujak and Williams, 1978; Barss et al., 1979; Haq et al., 1987; Pearce et al., 2003). However, as discussed above, it is likely that these are specimens of Canningia glomerata following the emended description of Prince et al. (1999), which is certain in the case of Pearce et al. (2003). Stover et al. (1996) placed the LO of $S$. protrusa at the base of the Santonian, and Williams and Buja.: (1985) in the intraLower? Santonian. However, the bulk of the literature sug ges $i s$ that the LO occurs in the mid-Santonian (Louwye, 1992), Middle Santonian (Fol che , 1975a, 1976a, b, 1979, 1983; Williams and Brideaux, 1975; Foucher and Rnbu czynski, 1977; Costa and Davey, 1992; Louwye, 1992) or, more precisely, in the upv ^r .Middle Santonian (Prince et al., 1999, 2008). Therefore, the FAD of S.protru: al, suggested to lie in the Middle Santonian in the Northern Hemisphere.

In East Kent and at Culver Cliff (Pı: ${ }^{\prime} r \_$et al., 2008), the LO of S. protrusa occurs in the Middle Santonian above the Baı - ois Sponge Bed and within the Horseshoe Bay CIE, respectively. In the Trunch boreh $\mathrm{Jl}^{2}$, the LO of S. protrusa (Spr) at $339.0 \mathrm{~m}$ also lies in the upper Middle Santonian ( $M$ co' ' nguinum Zone; Figs 6, 18), but slightly higher stratigraphically than in sout $t_{\text {. }}$ rn England. The stratigraphically lower record in Kent is estimated to have an age $\omega^{c} \sim \mathcal{\&} 5.25 \mathrm{Ma}$, and this is suggested to be the FAD. The LO of $S$. protrusa in the Trur $-\mathrm{h}$. or hole occurs slightly higher at isotope event $\mathrm{n} 2$, with a calculated age of $84.901=0.50$ ) Ma (Fig. 18).

\subsubsection{LAD of Spiniferites porosus (N. Hemisphere)}

\section{Taxonomy and geographic distribution}

Spiniferites porosus was originally described as a species of Hystrichosphera by Manum and Cookson (1964) from the Upper Cretaceous of Arctic Canada. It is restricted to the Northern Hemisphere mid-and high latitudes from $\sim 77^{\circ} \mathrm{N}$ (Graham Island, Canadian Archipelago: Manum and Cookson, 1964; Felix and Burbridge, 1976) to 
$\sim 36^{\circ} \mathrm{N}$ (northern Iran: Moradin and Allameh, 2010) and is distributed through North America, NW Europe, and central Asia.

The palaeolatitudinal range of $\sim 70^{\circ} \mathrm{N}$ (Graham Island, Canadian Archipelago: Manum and Cookson, 1964; Felix and Burbridge, 1976) to $\sim 30^{\circ} \mathrm{N}$ (northern Iran: Moradin and Allameh, 2010) suggests the species was well suited to north Boreal warm and Boreal tropical climate belts (Fig. 17h).

\section{Stratigraphy}

Hansen (1977) recorded Spiniferites porosus (Plate VI, 4) in the Upper Maastrichtian but found it restricted to "certain localities"; 1 : : unclear if these specimens were in situ. According to Williams and Bujak (19r5), the highest occurrence occurs in the mid-Santonian, which is consistent with t 1 e f 1 dings here with an $\mathrm{HO}$ at Trunch of 349.0 m (M. coranguinum Zone; Figs 6, 18।. Smelror et al. (1994) recorded $S$. porosus through the Turonian - Santonian interval in 'ne Norwegian Sea, but the LO is likely to occur in the post-Turonian since the $u$ lies above the reappearance of consistent 0 . pulcherrimum specimens (Sec ion 7.2.9.) that is taken as a Lower Coniacian marker. Therefore, the LAL $\neg f$ j.porosus (Spo) is suggested to lie in the midSantonian in the Northern Hemispi ?re following Williams and Bujak (1985). In the Trunch borehole, the event coinci $\left(e^{\prime},{ }^{+}\right.$the isotope peak immediately above the $\mathrm{m} 2 \mathrm{CIE}$, with a calculated age of $85.23( \pm 0.56)$ Ma.

\subsubsection{LO and LO of com.`on Chatangiella eminens (NW Europe?)}

\section{Taxonomy and geog - vinlc distribution}

Prince (1997) first recorded Chatangiella eminens as Arvalidinium "spinosum" from the upper Middle Santonian to Lower Campanian of Culver Cliff, southern England (but it was excluded from the species list of Prince et al., 1999). It was formally described by Pearce (2010) from the Trunch borehole as Chatangiella eminens (Plate I, 8). It has subsequently been recorded from offshore mid-Norway and questionably from Poland (pers. obs.). It therefore has a geographic range of $\sim 66-51^{\circ} \mathrm{N}$, with a palaeolatitudinal range of $\sim 56-41^{\circ} \mathrm{N}$ within the southern North Boreal warm climate zone (Fig. 19a). 


\section{Stratigraphy}

The LO of Chatangiella eminens (Cem) occurs in the upper Middle Santonian at the level of the $\mathrm{n} 1 \mathrm{CIE}$ in southern England (Prince, 1997) and at $346.0 \mathrm{~m}$ in the Trunch borehole (M. coranguinum Zone; lower part of the Horseshoe Bay CIE; Figs 6, 18). A significant up-section influx is noted in the Upper Santonian (Prince, 1997; at Buckle Marl 5, CIE o1) and this is also recognized at Trunch at $334.0 \mathrm{~m}$ (U. socialis Zone; between the Buckle Event and CIE o1; Figs 6, 18); the influx and acme appears to be a potentially correlatable event that warrant further testing. Both the LO and lowest common occurrence at Trunch are stratigraphically margir ally lower than in southern England with calculated ages of $85.06( \pm 0.59)$ Ma and $\left.84 . .^{\prime}{ }^{\prime} \pm 0.5\right)$ Ma, respectively (Fig. 18).

\subsubsection{HO of Renidinium rigidum (NW Europe?}

Section 7.4.5. provides a brief taxonomic anr. ge đraphic discussion of Renidinium rigidum.

\section{Stratigraphy}

According to Prince et al. (1999; 2008) the LAD of Renidinium rigidum occurs in the Middle Santonian, immediately beic w barrois Sponge Bed, midway between CIE m2 and the Horseshoe Bay CIE. In the "runch borehole, the $\mathrm{HO}$ of R. rigidum (Rri) at $345.3 \mathrm{~m}$ also occurs in the mid-Midd'o s 'ntonian (Micraster coranguinum Zone) but slightly higher, within the lower lin . $^{+}$of the Horseshoe Bay CIE, with a calculated age of $85.03( \pm$

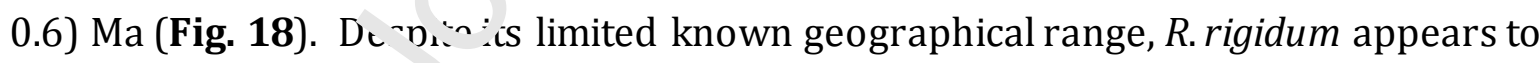
be an excellent biostri ${ }^{+i}$ sraphic marker species, which may have been missed in previous studies due to its short stratigraphic range.

\subsubsection{Reappearance of Coronifera striolata (NW Europe?)}

\section{Taxonomy and geographic distribution}

Coronifera striolata (Plate I, 11) was originally described as Hystrichosphaeridium striolatum by Deflandre (1937) from the Upper Cretaceous of France, and has subsequently been transferred to Baltisphaeridium and Exochosphaeridium prior to Coronifera (see Williams et al., 2017). Coronifera striolata is recorded from both 
hemispheres from $\sim 80^{\circ} \mathrm{N}$ (Mount Bridgeman, Ellesmere Island, Canadian Archepeligo: Núñez-Betelu et al., 1994) to 24N (DSDP 535, Gulf of Mexico: Riley and Fenton, 1984) in the Northern Hemisphere and from $\sim 19^{\circ} \mathrm{S}$ (offshore northwest Western Australia: Stover and Helby, 1987a) to $\sim 64^{\circ} \mathrm{S}$ (Antarctic peninsula: Dettmann and Thomson, 1987), and is well distributed through North America, North Atlantic, northwest Europe, southern and southeast Asia, southern Indian Ocean, Australia and Antarctica.

The palaeolatitudinal range of $\sim 70^{\circ} \mathrm{N}$ (Mount Bridgeman, Ellesmere Island, Canadian Archipelago: Núñez-Betelu et al., 1994) to 24º (DSDP 535, Gulf of Mexico: Riley and Fenton, 1984; ODP 635, The Bahamas: Masure, 1988) and $\sim 47^{\circ} \mathrm{S}$ (offshore northwest Western Australia: Stover and Helby, 1987a; Queen.-land, Australia: Burger, 1982 ) to $\sim 74^{\circ} \mathrm{S}$ (DSDP 275, offshore southwest New Zeala. d · Nilson, 1975) suggests $C$. striolata was a mid- to high latitude Boreal warm tax n 'Fi g. 19b).

\section{Stratigraphy}

The LO of C. striolata (Cst) occurs at 342. , $\mathrm{n}$. in the Trunch borehole (mid-Middle Santonian; Figs 6, 18) which is consistent $v$ ith the lowest persistent occurrence reported by Prince et al. (1999, rare $s_{r}{ }^{2} c^{\prime}$ mens were also recorded in the Lower Coniacian by Prince et al. 2008). In -nite of other supporting studies (Foucher and Robaszynski, 1977; Bujak and Wil ia «. - 1978; Herbin et al., 1987) this contrasts to other published work that sugcesı $\exists$ much lower LO.

Coronifera striolata was I r corded from the Lower Cretaceous ('Neocomian') by Gocht (1959, as Hystrichos, ha ridium cf. striolatum), Morgan (1980, as Exochosphaeridium $+r$ rlat $/ \mathrm{m}$ ), and Stover and Helby (1987a). However, the illustrated specimen provided by $G$ sht (1959) lacks the distinctive antapical process and that by Morgan (1980) appears to be Pervosphaeridium truncatum (known earlier as Exochosphaeridium striolatum subsp. truncatum); these records are discounted here. An example of $C$. striolata was not illustrated by Stover and Helby (1987a) and the record cannot, therefore, be verified.

Numerous studies suggest the LO of $C$. striolata occurs in the Albian (Cookson and Eisenack, 1971 as ?Exosphaerdium [sic] affinity striolatum; Steinkraus, 1980 but not illustrated), either in the Lower Albian (Prössl, 1990; Kennedy et al., 2000; not illustrated by either study), or in the Upper Albian (Foucher, 1979, 1980 - neither with illustrated specimens; Masure, 1988; Costa and Davey, 1992 - not illustrated, and based 
on oil well data from the North Sea, so the presence of caved specimens cannot be discounted). Clarke and Verdier (1967) and Robaszynski et al. (1982) recorded $C$. striolatum from the base of their study sections, in the Cenomanian. Additional studies by Riley and Fenton (1984) and Dodsworth (2000), confirm the presence of the species in the Cenomanian. Excluding the majority of the studies lacking illustrated specimens, those of Clarke and Verdier (1967) and Masure (1988) suggest that an Upper Albian LO is likely, and this is taken as the FAD here.

Studies documenting in situ Turonian (Foucher, 1975a, 1976a, 1976b; Núñez-Betelu et al., 1994; Tocher and Jarvis, 1987) and Coniacian (Foucher, 1971a; Williams and Brideaux, 1975; Schiøler, 1992; Prince et al., 2008) occurrence - of C. striolata corroborate a FAD that lies stratigraphically lower than th I.C, at Trunch.

In his upper Turonian - lower Campanian study o f I er Cliff, Prince (1997) recorded the LO of $C$. striolata from the upper Mid ite Santonian, falling between CIEs n1 and $\mathrm{n} 2$. This is equivalent to the $\mathrm{LO}$ at Trunch and $\mathrm{h}_{\mathrm{c}}$ - a calculated age of $84.96( \pm 0.54)$ Ma (Fig. 18). In a follow up paper of the Con ar.a l - Campanian from a composite section in Kent, Prince et al. (2008) alsr in un ${ }^{+}$C. striolata to be more persistently recorded upwards from the Lower Sanı nian. Therefore, in NW Europe, the reappearance of persistent $C$. striolal : is suggested to be a potentially useful marker of the Middle Santonian, but this requires testing.

\subsubsection{FAD Pervosphaeria: 'un. intervelum (NW Europe)}

\section{Taxonomy and geogr: $p_{1}$ : distribution}

Pervosphaeridium in :ervelum (Plate IV, 4) was described by Kirsch (1991) from the Campanian of Germany. Pervosphaeridium septatum Slimani 2001b from the Campanian of Belgium and the Netherlands appears to be very similar to P. intervelum. A morphological comparison of the holotypes (not provided by Slimani, 2001b) is required to confirm the validity of $P$. septatum.

Pervosphaeridium intervelum appears to be restricted to NW Europe from $\sim 55^{\circ} \mathrm{N}$ (northern North Sea, pers. obs.) to $\sim 36^{\circ} \mathrm{N}$ (northern Iran: Moradin and Allameh, 2010), with a palaeolatitudinal range of $\sim 45^{\circ} \mathrm{N}$ (northern North Sea, pers. obs.) to $\sim 30^{\circ} \mathrm{N}$ (northern Italy: Roncaglia, 2002; Roncaglia and Corradini, 1997; northern Iran: Moradin 
and Allameh, 2010) restricting the species largely within the southern North Boreal warm climate belt (Fig. 19c).

\section{Stratigraphy}

Pervosphaeridium intervelum is restricted to the Upper Cretaceous with the lowest published records from the Upper Santonian (Prince et al., 1999, 2008). The LO of $P$. intervelum (Pint) at Trunch at $342.3 \mathrm{~m}$ in the upper Middle Santonian (M. coranguinum Zone; Figs 6, 18) lowers the inception of the species, and this is tentatively suggested to be the FAD. In the Trunch borehole the event occurs at the negative excursion between the Horseshoe Bay and n2 CIEs with a calculated age of 84.9, $\_ \pm 0.54$ ) Ma (Fig. 18).

\subsubsection{FAD of Dimidium striatum (NW Europe)}

\section{Taxonomy and geographic distribution}

This species was originally described as G^nvaulacysta striata by Clarke and Verdier (1967) from the Santonian of southern Eng.ar J, and subsequently associated with Gonyaulacysta, Leptodinium, Impagidir ın , Pterodinium (See Williams et al., 2017) prior to Dimidium (Pearce, 2010). Confirmed records indicate that it is restricted to the Northern Hemisphere from $\sim 64^{\circ} \mathrm{N}^{-}{ }^{\circ}$ ou ihwest Greenland, Kangerdlugssuaq: Soper et al., 1976, as Leptodinium striatc', 'n . $35^{\circ} \mathrm{N}$ (southwest Korea: Yun et al., 2000) with additional records from soutlierı. England (Davey et al., 1969; Prince et al., 1999) and NW Germany (Yun 1981 and Larjeant, 1985). Williams and Brideaux (1975) recorded Dimidium striatum (as iony xulacysta striata; Plate II, 3) from western North Atlantic but on inspection their .'ustrated specimen possesses an apical horn and is therefore, a mis-identification, and is discounted here.

The narrow palaeolatitudinal range of $\sim 51^{\circ} \mathrm{N}$ (SW Greenland, Kangerdlugssuaq: Soper et al., 1976) to $\sim 41^{\circ} \mathrm{N}$ (southern England: Clarke and Verdier, 1967; southwest Korea: Yun et al., 2000) suggests $D$. striatum was principally associated with Boreal warm climates (Fig. 19d).

\section{Stratigraphy}

According to Pearce (2010), Heslertonia rugula Yun 1981 is a taxonomic junior synonym of D. striatum which were found to co-occur in the Santonian of Germany. Prince et al. (1999) also recorded the species as Pterodinium? striatum from the upper 
Middle Santonian of southern England, which is consistent with our findings from the Trunch borehole where the LO of D. striatum (Dst) occurs at $336.0 \mathrm{~m}$ in the uppermost Middle Santonian (uppermost $M$. coranguinum Zone; mid-Buckle CIE) with a calculated age of $84.85( \pm 0.5)$ Ma. The stratigraphically lower record by Prince et al. (1999) from Culver Cliff is tentatively taken to represent the FAD of the species. This occurs midway between CIEs $n 1$ and $n 2$ with an estimated age of $~ 84.94$ Ma.

\subsubsection{LO of Spiniferites jarvisii (NW Europe?)}

Spiniferites jarvisii (Plate VI, 2) was described by Pearce (2010) from the Santonian of the Trunch borehole with a LO at $337.0 \mathrm{~m}$ in the uppermosı.Middle Santonian (uppermost M. coranguinum Zone; Figs 6, 18, Sja). Due to ts distinctive morphology, the first occurrence of this species is suggested to be $f_{\text {ntf }}$ ntial useful marker for the Middle/Upper Santonian boundary. It has been or st. ved from the Santonian of the Norwegian North Sea and Poland (pers. obs.; Fig. 14 !. but more records are required to establish the geographic distribution and l kf, iy FAD. At Trunch the event falls immediately below the Buckle CIE with a aı rlated age of 84.87 ( \pm 0.5$)$ Ma (Fig. 18).

\subsubsection{FAD of Odontochitina diducu. (NW Europe?)}

\section{Taxonomy and geographic di « ibution}

Odontochitina diducta (PI.te III, 10) was described by Pearce (2010) from the high Offaster pillula Zone (mid-i nn er Campanian) in the Trunch borehole, and an emended description of the sk a ${ }^{\circ} \mathrm{s} \mathrm{n}$ as provided by Pearce (2018) to broaden the morphological variability in the type $\mathrm{m}$ : terial. It is restricted to NW Europe from $\sim 66^{\circ} \mathrm{N}$ (offshore mid-Norway, pers. obs.) to $\sim 51^{\circ} \mathrm{N}$ (southern England: as Odontochitina sp. a, Prince et al., 2008) with additional records from the Norwegian North Sea $\left(\sim 61^{\circ} \mathrm{N}\right.$, pers. obs.) and the North Sea $\left(\sim 55^{\circ} \mathrm{N}\right.$, as Odontochitina sp. a, Costa and Davey, 1992, but without description; and pers. obs.). Keating (1992) recorded a very similar form (as Odontochitina sp. II) but which differs by apparently possessing a particularly thick periphragm; however, no diagnosis was provided so this record is not included. Prince (1997; as O.sp. a Costa and Davey 1992) discriminated this species by the presence of "widely diverging [presumably the lateral from antapical] horns" but did not provide 
measurements, but which were later suggested by Pearce (2010) to be equal to or greater than $80^{\circ}$.

The palaeolatitudinal range of from $\sim 56^{\circ} \mathrm{N}$ (offshore mid-Norway, pers. obs.) to $\sim 41^{\circ} \mathrm{N}$ (southern England: Prince et al., 2008) indicates that O.diducta was associated with areas of Boreal warm climate (Fig. 19f).

\section{Stratigraphy}

Prince et al. (2008) recorded rare and sporadic specimens of $O$. sp. a from the lower Coniacian (M. cortestudinarium Zone), and from the upper Santonian (M. testudinarius Zone; isotope event 03 of Jarvis et al. 2006 fig. 11) from soul. arn England. The first occurrence in the Trunch borehole occurs at $336.0 \mathrm{~m}$ in th e uf permost middle Santonian (uppermost M. coranguinum Zone; mid-Buc le e rent; Figs 6, 18, Odi) and appears to be comparable with the lowest Santonian I r ord of Prince et al. (2008) with a calculated age of 84.85 ( \pm 0.5) Ma (Fig. 18). Give. the unknown angle separating the horns in the specimens recorded in the Conia $1 \mathbf{l}^{\prime}$ ) these records are excluded.

\subsubsection{LO of Odontochitina porifera ? $N$ Europe)}

\section{Taxonomy and geographic distrihus:on}

Odontochitina porifera (Pla'.. Il:, 11) was described by Cookson (1956) from the 'Senonian' of Australia. It has a cu smopolitan distribution from $\sim 74^{\circ} \mathrm{N}$ (eastern Greenland: Nøhr-Hansen, 201?) to $\sim 66^{\circ} \mathrm{S}$ (ODP 1167, East Antarctica: Macphail and Truswell, 2004).

The palaeolatitudin. $\mathrm{l}$ range is $\sim 61^{\circ} \mathrm{N}$ (Alberta, Canada: Fensome and Norris, 1982) to $\sim 69^{\circ} \mathrm{S}$ (ODP 1167, east Antarctica: Macphail and Truswell, 2004; Fig. 19g). The precise temporal and special distribution of this species may be complicated due to its similarity to $O$. cribropoda and $O$. striatoperforata (junior synonym of $O$. costata), that also possesses perforated horns.

\section{Stratigraphy}

In the type material from Australia, Cookson (1956) also described additional new species as Gymnodinium (now Dinogymnium) nelsonense and Deflandrea (now Manumiella) cretacea. According to Helby et al. (1987) the range of these species is considered to be Santonian to Lower Maastrichtian and mid-Santonian to Lower 
Maastrichtian, respectively, indicating that $O$. porifera exists in post-Coniacian sediments. Helby et al. (1987) considered the range of 0 . porifera to be from the base of the Santonian to Lower Campanian. Additional ranges for O. porifera have been given as spanning the Santonian and Campanian (Keating 1992) and ?Upper Santonian to uppermost Campanian (Wilson, 1984). Askin (1988), Dolding (1992), Wood and Askin (1992) and Schiøler and Wilson (1998) recorded O. porifera within the Campanian, while Smith (1992) indicated that the upper range may lie in the Maastrichtian. More recent studies from the Southern Hemisphere, calibrated by magnetostratigraphy (Crampton et al., 2000), place the base of the O. porifera Zone of Schiøler and Wilson (1998, defined by the LO of O. porifera) in New Zealand, within the mid-Lower Santonian.

In the Northern Hemisphere, Prince et al. (1999) $x^{*} \sim n r$ ded the LO of the species from the macrobiostratigraphically calibrated low -I ' 'nuer Santonian (U. socialis Zone) and well into the Lower Campanian of southern E' $g_{1}$ 'nd, and Sigal-Farkas (1997) recorded the species (as 0 . porifera-striatope. $f r, r(t a)$ from the uppermost Santonian well into the mid-Campanian of Hungar $r_{y}$. M reover, Campanian occurrences of $O$. porifera from the Northern Hemisphere re further corroborated by Kirsch (1991) from Germany, and Antonescu et al. (2001i) and Schiøler and Wilson (2001) from France. Nøhr-Hansen et al. (in press) desc $i$ je the LO of $O$. porifera to occur in the middle part of their Chatangiella "spinosa" (nc v Criatangiella islae Zone that spans the middle Coniacian to middle Santoni $n$ and place the event at the base of the Santonian. These data suggest that a near ${ }_{0}^{-1} \mathrm{n} L-1$ ly synchronous appearance of 0 . porifera occurred in the Early Santonian, ana . rili. : espect to Nøhr-Hansen et al. (in press) consider our LO of $O$. porifera in the Upper 5-...tonian to be a NW European event, until a precise mid - to high northern hemisphere correlation can be achieved.

At Trunch and in East Kent (Prince et al., 2008), the LO occurs between the o3 and the Hawks Brow CIEs with a calculated age of $84.59( \pm 0.50)$ Ma (Figs 6, 18, Opo). At Culver Cliff (Prince et al., 1999) the LO of 0 . porifera has been recorded slightly lower, between CIEs 01 and o2, giving an estimated age of 24.73 Ma (Fig. 18); this is considered to be the age of the LO in the NW Europe. 


\section{Discrepancy with Canadian data}

Based on palynological data from offshore southeastern Canada, Williams (1975) defined 11 zones for the Cretaceous, but whose chronostratigraphies were stated to be tentative due to a lack of macrofossil calibration. The lowest occurrence of $O$. porifera was found in his Oligosphaeridium pulcherrimum Zone that was believed to be of Coniacian age, and was defined as the interval from the latest (stratigraphically highest) common occurrence of Surculosphaeridium longifurcatum at the base, to the latest occurrence of Oligosphaeridium pulcherrimum at the top. Additional events within the zone include the LO of $R$. truncigerum and the HOs of Callai snhaeridium asymmetricum and Scriniodinium campanula.

In the Trunch borehole, the highest common occurr.nce of $S$. longifurcatum occurs at the base of the Upper Santonian (U. socialis Zone) = na :ie highest occurrence of $O$. pulcherrimum occurs in the Lower Campanian ( $O$ sill ' $a$ Zone). Furthermore, the HOs of Callaiosphaeridium asymmetricum and Scrinioc'iniu..2 campanula (see Sections 7.3.2. and 7.4.23.; Fig. 6) occur in the Middle and $\mathrm{J}_{1}^{-}$oe: Santonian, respectively, with the LO of $O$. porifera occurring in-between at $250 \mathrm{~m}_{\mathrm{t}}$ in the lower Upper Santonian (mid- $U$. socialis Zone). This suggests a miscalibra: nn of the chronostratigraphy of the offshore SE Canadian wells or a difference in tas nomic concept for O. porifera.

The FAD of 0 . porifera in the Co ${ }^{2}{ }_{\lambda}$ cian was assumed by Williams and Brideaux (1975), Bujak and Williams (19;9), Williams and Bujak (1985), Haq et al. (1987; but presumably based on Willian. and Bujak, 1985). The same assumption was made by Williams et al. (1993, b ist ton Williams and Bujak, 1985) who included new references but provided no updaı tor the Coniacian to Campanian. Similarly, Stover et al. (1996, presumably following villiams et al., 1993 but stated to be based on European data), and Schrank and Ibrahim (1995, but based on Williams et al., 1993) assumed a Coniacian FAD. All these studies place the highest occurrence of $O$.porifera in the Middle Santonian with the LAD dated to be 84.70 Ma by Fensome et al. (2008), i.e. actually below the lowest occurrence at Trunch. Prince et al. (2008) recorded a single specimen of 0 . porifera from the mid-Middle Coniacian of Whitecliff (Isle of Wight, southern England), but with the next appearance of specimens in the Upper Santonian (upper U. socialis Zone).

In summary, the FAD of 0 . porifera remains unclear and it may either occur in the Early Coniacian (Canadian Atlantic) or Early Santonian (Southern Hemisphere and 
Europe), although the bulk of calibrated data suggest the latter. Since the lowest occurrence in NW Europe is slightly higher than in the Southern Hemisphere, it represents a $\mathrm{LO}$ rather than FAD; an age of $84.73 \mathrm{Ma}$ for the LO of 0 . porifera in given for NW Europe only. The LAD lies in the Campanian or questionably Maastrichtian; the LAD reported by Fensome et al. (2008) is a local HO only.

\subsubsection{LO of Trimuridinium whitenessense (NW Europe?)}

\section{Taxonomy and geographic distribution}

Trimuridinium whitenessense (Plate VI, 10) was origina.:- described as Senoniasphaera whitenessii by Prince et al. (2008) from th 3 Uk per Santonian of southern England, and transferred to Trimuridinium $w$ th $t$ le correct species epithet of "ense" (after the type area of White Ness, East Kent) hy Fensome et al. (2019). It has only been documented from the English Chalk (an a dritional record was provided by Prince, 1997 as Senoniasphaera sp. a), but its ,c: rcity is likely due to the recent discovery of the species. The known palae $\iota^{\prime}$ tatitudinal range is $\sim 43^{\circ} \mathrm{N}$ (Trunch borehole, this study) to $\sim 41^{\circ} \mathrm{N}$ (south ${ }^{\sim r}$ England: Prince, 1997; Prince et al., 2008) in an area of Boreal warm climate (Fis. 17d).

\section{Stratigraphy}

The lowest occurrence $T$ whi'enessense (Twh) in the Trunch borehole occurs at 301 $m$ in the Lower Campanian ( 6 , ${ }^{\text {, }}$ aster pillula Zone; Figs 6, 18), with a calculated age of 84.07 ( \pm 0.5 ) Ma. The $\mathrm{\epsilon}$ ven occurs stratigraphically lower in East Kent (Prince et al., 2008), where the LO oc. urs between CIEs o1 and o2, with an estimated age of $\sim 84.73$ Ma (Fig. 18).

\subsubsection{HO of common Chatangiella eminens (NW Europe?)}

A brief taxonomic and geographic discussion for Chatangiella eminens is provided in Section 7.4.10.

\section{Stratigraphy}

In the Trunch borehole, the HO of common C. eminens (Cem) occurs at $326.0 \mathrm{~m}$ in the lower Upper Santonian (mid-U. socialis Zone) immediately above the o3 CIE (Figs 6, 18). At Culver Cliff, the $\mathrm{HO}$ of common C. eminens (as Chatangiella "spinosa"; Prince, 
1997) occurs at precisely the same horizon, but the species extends infrequently to a final HO in the Lower Campanian. The HO of common C.eminens is, therefore, taken to represent potentially useful event for the Upper Santonian with a calculated age of 84.61 ( \pm 0.5) Ma (Fig. 18).

\subsubsection{LAD of Heterosphaeridium difficile (worldwide)}

A brief taxonomic and geographic discussion for Heterosphaeridium difficile is presented in Section 7.2.1.

\section{Stratigraphy}

Brideaux and Myhr (1976) recorded Hystrichosphaeri tiun sp. cf. H. difficile sensu

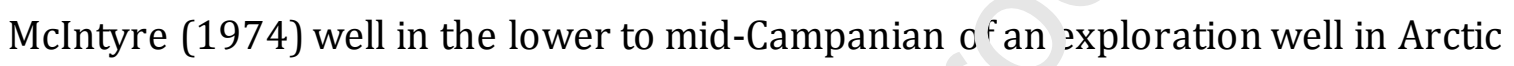
Canada. However, this form (illustrated in McIntyre + 774) appears to more closely resemble Hystrichosphaeridium paracostatum Coos ${ }^{-11}$ and Eisenack 1974, and this record is discounted. McIntyre (1974) illustr ${ }_{1}$ t $\mathrm{J}$ a similar form as Hystrichosphaeridium sp. 3 (cf. H. difficile) f: om nis undifferentiated Santonian Campanian interval, but we do not col ${ }_{1}$ id er this sufficiently similar to the holotype of Heterosphaeridium difficile to be coı cidered either.

Stratigraphic studies in West ir « rland indicates that the LAD of H. difficile occurs in the Santonian. Nøhr-Hanser (1 294) recorded the HO near the top of his undifferentiated Coniacian - ¿nper Santonian interval, and Nøhr-Hansen (1996) reported the $\mathrm{HO}$ at the bas - of an undifferentiated Upper Santonian - Lower Campanian interval. Núñez-Bet`lu st a . (1994) recorded persistently occurring specimens of $H$. difficile with a HO well b sfore the top of the Kanguk Formation in Arctic Canada (dated as Late Turonian to Early Campanian by Núñez-Betelu et al., 1992). Costa and Davey (1992) placed the HO at the Lower / Upper Santonian boundary, which is consistent with Williams and Bujak (1985), Williams et al. (1993), and Stover et al. (1996). NøhrHansen et al. (2016) place the HO of H. difficile at the top of the Lower Santonian, and Fensome et al. (2008) placed the HO in the middle of an undifferentiated Santonian interval.

In his study of the Upper Cretaceous of Culver Cliff, southern England, Prince (1997; not shown in Prince et al., 1999) place the HO in the lower Upper Santonian (mid- $U$. socialis Zone) above CIE o2. Therefore, the LAD of H.difficile is suggested to lie in the 
Late Santonian worldwide. This is supported by the Santonian HO reported by Keating (1992) for the Southern Hemisphere. In the Trunch borehole the HO of $H$. difficile (Hdif) occurs at $326.0 \mathrm{~m}$ in the lower Upper Santonian (mid-U. socialis Zone; Figs 6, 18), immediately above CIE o3 and this is taken to represent the LAD of the species, with a calculated age of $84.61( \pm 0.50)$ Ma.

\subsubsection{LO of Cordosphaeridium catherineae (NW Europe?)}

Cordosphaeridium catherineae (Plate I, 10) was described by Pearce (2010) from the Santonian of the Trunch borehole. It has also been observed from southern England (Iain Prince pers. comm., but was not mentioned in his publisı $\urcorner d$ studies of the area), and from the Upper Santonian of Poland (pers. obs.; Fig. 1 'h) In the Trunch borehole, the lowest occurrence at $323.0 \mathrm{~m}$ in the mid-Upper Si n nn an (upper U. socialis Zone; Figs 6,18 ) is included here as a potential bioeven ${ }^{+} \mathrm{un}^{\text {? }}$ to its easily recognizable form. The event occurs immediately below the Hawks B 0 v CIE with a calculated age of 84.55 $( \pm 0.5)$ Ma (Fig. 18, Cca). More records are $n$ er es ;ary to determine if this age represents the FAD of the species.

\subsubsection{FAD of Rhynchodiniopsis sa: :orum (NW Europe)}

\section{Taxonomy and geographic di « ibution}

This species has common.r been referred to as Spongodinium "cristatum" or a species of Cribroperidiniur. wi th particularly well-developed crests, in unpublished biostratigraphic cor-ul ant reports on the Upper Santonian and Lower Campanian of the NW Europe. It was $\mathrm{t}$ )rmally described as Rhynchodiniopsis saliorum (Plate V, 1) by Louwye (1995) from the Lower Campanian of Belgium, where its lowest occurrence was recorded in the lowermost Campanian. Prince (1997 unpublished, as Rhynchodiniopsis sp. a) recorded a consistent lowest occurrence in the mid-Upper Santonian (base M. testudinarius Zone) of two southern England sites (where it occurs sporadically), but the species was omitted from the published lists of Prince et al. (1999, 2008). Slimani (2001a) also recorded the species from Belgium and southern Netherlands. 
The palaeolatitudinal range of $\sim 56^{\circ} \mathrm{N}$ (offshore mid-Norway, pers. obs.) to $\sim 41^{\circ} \mathrm{N}$ (Belgium: Louwye, 1995; Slimani, 2001a; southern England: Prince, 1997) suggests that the species was restricted to an area of southern North Boreal warm climate (Fig. 20a).

\section{Stratigraphy}

Personal observations from the Barents Sea and Norwegian Sea suggest that the species has a consistent lowest occurrence within the Upper Santonian, although the precise position is unclear. The LO of $R$. saliorum $(R s a)$ in the Trunch borehole occurs at $312.0 \mathrm{~m}$ in the high Upper Santonian (mid-M. testudinarius Zone: Figs 6, 18) immediately above CIE q1 with a calculated age of 84.37 ( \pm u.16) Ma. Records from southern England indicate a stratigraphically lower LO, w thin the interval of the Hawks Brow CIE (summit of the $U$. socialis Zone; coincident w th t e LAD of Scriniodinium campanula), dated here as $84.53( \pm 0.50)$ Ma (Fig. 18.

\subsubsection{LAD of Scriniodinium campanula (N 1 emisphere)}

\section{Taxonomy and geographic distribut on}

Scriniodinium campanula (Plate V, 3) was described by Gocht (1959) from the Hauterivian of northwestern Germa.'v. It has been associated with Endoscrinium (see Williams et al., 2017). We agre'. vit.. Harker and Sarjeant (1975) and Brideaux and McIntyre (1975) that it is a s=nio» synonym of Gonyaulacysta fragosa Brideaux 1971.

Scriniodinium campar ula :as been recorded in both hemispheres from $\sim 82^{\circ} \mathrm{N}$ (northern Ellesmere Is' ana Canadian Archipelago: Nøhr-Hansen and McIntyre, 1998) to $\sim 38^{\circ} \mathrm{S}$ (west North Islaı. d, New Zealand,:Helby et al., 1988), but is conspicuously absent from $\sim 24^{\circ} \mathrm{N}$ (DSDP 99, Carribbean: Hollister et al., 1972; ODP 535, southeast Gulf of Mexico: Riley and Fenton, 1984) to $\sim 6^{\circ} \mathrm{S}$ (Papua New Guinea: Davey, 1988). It is distributed through North America, North Atlantic, NW Europe, NW Africa, Asia, eastern Indian Ocean and Australia, (Fig. 20b). It is conspicuously absent from the South Atlantic Ocean.

The palaeolatitudinal range of $\sim 83^{\circ} \mathrm{N}$ (north Alaska: May, 1979, Witmer et al., 1981) to $\sim 11^{\circ} \mathrm{N}$ (central Iraq: Al-Ameri et al., 2001) and from $\sim 32^{\circ} \mathrm{S}$ (Papua New Guinea: Davey, 1988) to $\sim 62^{\circ} \mathrm{S}$ (west North Island, New Zealand: Helby et al., 1988) suggests 
that the species was widespread in arid, Boreal warm and Boreal tropical climate zones but was intolerant of fully tropical conditions (Fig. 20b).

\section{Stratigraphy}

Scriniodinium campanula has a LAD in the Santonian, either in the upper (Williams and Bujak, 1985) or lower (assuming a bipartite division; Costa and Davey, 1992) portion of the stage. Supporting, but poorly calibrated, stratigraphic evidence for an Upper Santonian LAD is provided by Ioannides (1986 - HO in the lower part of an undifferentiated Santonian - Campanian interval), Kirsch (1991 - in the upper part of the Upper Santonian), and Núñez-Betelu et al. (1994) who r 'orded persistently occurring specimens that have a HO well below the top of Kan juk Formation (referred to the Upper Turonian to Lower Campanian by Núñez- Bet€'u et al., 1992). Evidence for a Lower Santonian HO is provided by Foucher (1976a, 1976b, 1979), Williams and Brideaux (1975) and Nøhr-Hansen (1994, 1996 - bitr from a single sample in an undifferentiated Coniacian - Lower Santonia' 1 ir cierval).

In his macrofossil-calibrated study, Pri. se et al. (1999) recorded the HO of $S$. campanula (Sca) in the mid-Upper Sar 2 an (with a tripartite subdivision; upper $U$. socialis Zone), which is consistent $w^{: t h}$ our records from the Trunch borehole (HO recorded at $322.0 \mathrm{~m}$; Figs 6, 18). I't nfore, the LAD of $S$. campanula is suggested to lie in the mid-Upper Santonian in he ''orthern Hemisphere. AtCulver Cliff, the HO of $S$. campanula occurs at the first n sitive isotope peak below the Hawks Brow CIE; the event occurs slightly hight : at Trunch within the interval of the Hawks Brow CIE. This isotope event is con? 9 'en ly taken to represent the LAD of the species with a calculated age of $84.531=0.50$ ) Ma (Fig. 18).

\subsubsection{LAD of Kleithriasphaeridium readei (N. Hemisphere)}

\section{Taxonomy and geographic distribution}

This species was originally described as Hystrichosphaeridium readei by Davey and Williams (1966b) from the Cenomanian of SE England. It has been recorded from both hemispheres from $\sim 73^{\circ} \mathrm{N}$ (Barents Sea: Århus, 1991) to $\sim 26^{\circ} \mathrm{S}$ (southeast Brazilian continental shelf: Arai, 1994) and through North America, South America, North Atlantic, NW Europe, NE Africa, southeast Asia and Australia. No occurrences have been 
reported between $\sim 30^{\circ} \mathrm{N}$ (northern Egypt: El-Beialy, 1995) to $\sim 4^{\circ} \mathrm{S}$ (Papua: Fraser et al., 1993).

The palaeolatitudinal range of $\sim 63^{\circ} \mathrm{N}$ (Barents Sea: Århus, 1991 ) to $\sim 12^{\circ} \mathrm{N}$ (northern Egypt: El-Beialy 1995) and $\sim 32^{\circ} \mathrm{S}$ (southeast Brazilian continental shelf: Arai, 1994 ) to $\sim 51^{\circ} \mathrm{N}$ (west Western Australia: Backhouse, 2003) indicates the species favoured arid and mid-latitude Boreal warm climate zones (Fig. 20c).

\section{Stratigraphy}

According to Davey and Verdier (1976) the HO of Kleithriasphaeridium readei (Plate III, 6) lies in the 'Senonian'; possibly, due to either qu stionable specimens (Foucher and Robaszynski, 1977) or uncertain stratigrapl v ( $\mathrm{k}$ ujak and Williams, 1978), within the Santonian. Other studies point to a Coniacia $1 \mathrm{H}_{1}$ ), either at the top (Foucher,

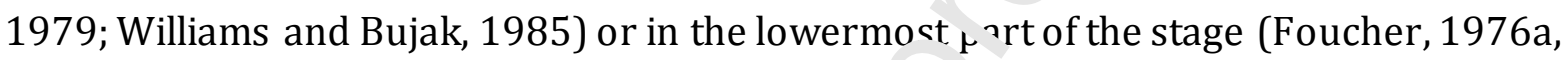
b). The species has not been observed in many stuc ${ }^{\prime i c}$, that focus on the stratigraphic range of the species, and it is conspicuously $v$. $1 \mathrm{r}$-rorded in key papers on the Cenomanian to Campanian chalks of south " n england (Clarke and Verdier, 1967; Prince et al., 1999, 2008; Pearce et al., 20's3) and from the Upper Cenomanian to Maastrichtian chalks of Germany (i : össl, 1990; Kirsch, 1991).

In the Trunch borehole, the H Jr, ${ }^{2}$. readei (Kre) occurs at $321.0 \mathrm{~m}$ in the midUpper Santonian (upper U. soci xlis ?one; Figs 6, 18); however, although its occurrence is never particularly consiste ${ }^{+}{ }^{+}$the species is more typical of the Coniacian. The LAD is suggested to lie in the Latt Sar tonian, in support of Foucher and Robaszynski (1977) and Bujak and Willic ms (1c 78). However, the top of consistently occurring specimens may be in the Coniacian although it is unclear where in the stage this lies. The LAD in the Santonian is placed immediately above the Hawks Brow CIE, with a calculated age of 84.52 ( \pm 0.50$)$ Ma (Fig. 18).

\subsection{Lower Campanian}

Four lowest occurrence events are discussed here: (1) LO of persistent Whitecliffia spinosa; (2) LO of Alterbidinium ioannidesii; (3) FAD of Dinopterygium alatum; (4) LO of Spiniferites multispinulus. 


\subsubsection{LO of persistent Whitecliffia spinosa (NW Europe?)}

\section{Taxonomy and geographic distribution}

Whitecliffia spinosa (Plate VI, 11) was originally described as Pterospermopsis spinosa by Clarke and Verdier (1967) from the Santonian of southern England. It has subsequently been combined with Pterospermella, questionably with Thalassiphora (see Williams et al., 2017) and finally with Whitecliffia by Pearce (2010) as the type species. It is typical of the Northern Hemisphere from $\sim 55^{\circ} \mathrm{N}$ (Norwegian Sea; pers. obs.) to $\sim 44^{\circ} \mathrm{N}$ (Scotian Shelf: Barss et al., 1979) and is distributed through the North Atlantic, and NW Europe. Sarkar and Prasad (2000) recorded W. spir .sa from the Paleogene of northern India $\left(\sim 16^{\circ} \mathrm{N}\right)$ but this is omitted from our recol ds c ue to its isolated occurrence and because its position falls outside the ac sep $ə$ d palaeolatitudinal (estimated as $\sim 5^{\circ} \mathrm{N}$ ) and temporal range of the speries 'see below).

The narrow palaeolatitudinal range of $W$. spinc 'n ${ }^{2}$ rom $\sim 45^{\circ} \mathrm{N}$ (Norwegian Sea; pers. obs.) to $\sim 37^{\circ} \mathrm{N}$ (western France: Masur , , 983; Scotian Shelf: Barss et al., 1979), places the species tightly towards the souti. arn umit of the North Boreal warm climate belt (Fig. 20d).

\section{Stratigraphy}

According to Bujak and Wil' in $m_{s}$ (1978) and Barss et al. (1979), the lowest occurrence of W. spinosa occ rs is. the Coniacian. Foucher (1979) also placed the LO of W. spinosa in the ?Lower ronı.. cian but stated that this was based on data from Clarke and Verdier (1967); this is ncorrect since Clarke and Verdier (1967) recorded the lowest occurrence in th. Upper Santonian, M.testudinarius Zone. Prince et al. (1999, 2008) recorded rare specimens of $W$. spinosa in a few samples from Upper Santonian chalks, but a lowest persistent occurrence is apparent within the Lower Campanian (Prince et al., 1999 fig. 2). This lowest persistent occurrence lies in the middle of the Santonian / Campanian Boundary Event CIE, above the FAD of Uintacrinus anglicus, with an estimated age of $\sim 84.15 \mathrm{Ma}$. The LO of $W$. spinosa was recorded in the lowermost Lower Campanian of Belgium by Louwye (1992). However, Foucher (1979) placed the LO at the Coniacian/Santonian boundary; this requires high-resolution testing before it can be used to confidently extend the range of the species downwards. The LO of W. spinosa (Wsp) in the Trunch borehole at $292.0 \mathrm{~m}$, in the Lower Campanian 
(Offaster pillula Zone; Figs 6, 21), is comparable with the lowest persistent occurrence of Prince et al. (1999) and the LO of Louwye (1992), and has a calculated age of 83.91 ( \pm 0.50) Ma.

\subsubsection{LO of Alterbidinium ioannidesii (N. Hemisphere)}

Alterbidinium ioannidesii was figured by Ioannides (1986) as Dinoflagellate sp. E (without a description), from $\sim 73^{\circ} \mathrm{N}$ (Bylot Island, Canadian Archipelago), questionably from Maastrichtian strata. It was formally described as Alterbidinium ioannidesii (Plate I, 1) by Pearce (2010) from the Trunch borehole (the most southerly known locality at $\sim 53^{\circ} \mathrm{N}$ ). The species has been recovered from the Western In ^rior Seaway (Da Gama et al., 2014), and exploration well material from the Davie. Str ait (Nøhr-Hansen et al., 2016), and the North Sea, Norwegian North Sea, Norv $e_{c}^{\text {ia }}$ ', sea and offshore mid Norway (pers. obs.) from the Upper Santonian? - J ov al Campanian sediments, where it can often constitute a common or even abundant r. r portion of the palynoflora. It should be noted that the precise chronostrat sra\} hic calibration has not been demonstrated. The palaeolatitudinal $\mathrm{r}^{\sim} \wedge_{\mathrm{r}} \mathrm{e} \iota^{f} \sim 67^{\circ} \mathrm{N}$ (Bylot Island, Canadian Archepeligo: Ioannides, 1986) to $\sim 43^{\circ} \mathrm{N}$. Trunch borehole, this study) suggests the species is restricted to North Boreal v. .rm mid-latitudes (Fig. 20e).

The LO of A. ioannidesii (Aio) $\mathrm{l} \mathrm{l} \mathrm{ch}=$ Trunch borehole at $299.0 \mathrm{~m}$ in the Lower

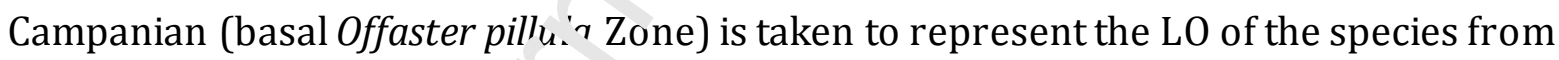
its most southerly distributi $\sim \mathrm{n}^{\mathrm{i}} \mathrm{mit}$ at $\sim 42^{\circ} \mathrm{N}$, with a calculated age of $84.05( \pm 0.5) \mathrm{Ma}$ (Fig. 21).

\subsubsection{LAD of Dinopt ygium alatum (N. Hemisphere)}

\section{Taxonomy and geographic distribution}

Dinopterygium alatum (Plate II, 5) was originally described as Hystrichodinium alatum from the Albian - Cenomanian of Australia by Cookson and Eisenack (1962). It has subsequently been associated with Pyramidium, Oodnadattia and Xiphophoridinium (see Williams et al., 2017) prior to Dinopterygium by Fensome et al. (2009). It has a cosmopolitan distribution from $\sim 74^{\circ} \mathrm{N}$ (NE Greenland: Nøhr-Hansen, 1993 ) to $\sim 44^{\circ} \mathrm{N}$ (Chatham Islands, New Zealand: Mildenhall and Wilson, 1976), with a remarkably wide 
palaeolatitudinal range of $\sim 83^{\circ} \mathrm{N}$ (north Alaska: Witmer et al., 1981) to $\sim 68^{\circ} \mathrm{S}$ (Chatham Islands, New Zealand: Mildenhall and Wilson, 1976; Fig. 20f).

\section{Stratigraphy}

In their study of the Belgium chalks, Foucher and Robaszynski (1977) recorded Dinopterygium alatum from the Lower Maastrichtian, corroborated by Foucher (1979). Robaszynski et al. (1985) recorded rare D. alatum in a single sample from the Lower Maastrichtian of the Stage type area (Early Maastrichtian occurrences were considered to be reworked by Nøhr-Hansen, 1996), but found rare D. cf. alatum to be generally restricted to the Lower Campanian. This is supported by Kis sh (1991) who recorded D. alatum from several samples in the (presumably) Lowt ${ }^{r}$ Ca npanian of Germany. An HO in the mid-Lower Campanian was suggested by Pri ıce , $t$ al. (1999) who recorded $D$. alatum reasonably consistently into the mid-O. pillula Inne, but the species was absent from the remainder of the Campanian (Prince, unp.'n!shed data). A Lower Campanian HO is apparent in the Southern Hemisphere. $x$ i iøler and Wilson (1998) recorded $D$. alatum ranging into the Lower Campanian ; their section top) of New Zealand, but it was only recorded twice (presumably rew rr $\mathrm{ed}$ ) in seventy-eight samples from five Campanian sections by Roncaglia e $\urcorner$ l. (1999). Marshall (1990) listed the species from offshore southern eastern Austra' $\mathrm{a}_{\Perp} \wedge$ ? $\mathrm{m}$ a dredge sample dated as Campanian; however, it was not recorded fi on. ? nearby exploration well and therefore, cannot be confirmed to be in situ.

In the Trunch borehos the HO of D. alatum (Dal) is recorded at $329.0 \mathrm{~m}$ in the lower Upper Santor: '7n 'mi l-U. socialis Zone; Figs 6, 18) and therefore, stratigraphically lower than the studies d scussed above. Numerous other work supports a HO in the Santonian: Dinopterygium alatum has not been recorded in several detailed stratigraphic studies of the Campanian (Harker et al., 1990; Heine, 1991; Antonescu et al., 2001a) or Maastrichtian (Marheinecke, 1992; Antonescu et al., 2001a). The HO has been reported variously in the Upper (Foucher 1975a, 1976a, b, 1979; Williams and Bujak, 1985; Williams et al., 1993; Stover et al., 1996), Middle (Costa and Davey 1992; Masure et al., 1998; Fensome et al., 2008) or Lower Santonian (Williams and Brideaux, 1975). Considering all the evidence, the LAD of D. alatum is suggested to lie in the earliest Early Campanian, but Upper Santonian HOs in the Northern Hemisphere are typical. 
In the Trunch borehole, the HO of D. alatum occurs between CIEs o 2 and o3 with a calculated age of $84.68( \pm 0.5) \mathrm{Ma}$, which is in close agreement with that of Fensome et al. (2008). However, the HO provided by Prince et al. (1999) occurs approximately three-quarters of the way through the 0 . pillula Zone (their top sample was $\sim 3 \mathrm{~m}$ below top of the Zone). This yields a slightly younger estimated age of $\sim 83.45$ Ma (Fig. 21, Smu).

\subsubsection{LO of Spiniferites multispinulus (NW Europe?)}

Spiniferites multispinulus (Plate VI, 3) was described bv Pearce (2010) and is currently only known from the Lower Campanian of the Trunc: borehole. The temporal and spatial distribution remains to be determined due to i $r$, cent discovery, but it may have been overlooked in the literature due to its simila : to o S.ramosus subsp. gracilis (Davey and Williams 1966a) Lentin and Williams ' 1 ,, 3 isee Pearce 2010 for comparison). In addition, given its relatively shor ${ }^{2} \mathrm{ra}^{\mathrm{n}} \mathrm{nge}$, it is unlikely to be found without tight sampling. However, as a distinctiv e species, it is included here as a potential bioevent for the Lower Camp? .1. ㄱ. vith a lowest occurrence at $277.0 \mathrm{~m}$ (upper Offaster pillula Zone) with a calcu ated age of 83.40 ( \pm 0.49 ) Ma (Fig. 21).

\section{Conclusion}

A new organic walled dinn.' 7 geilate cyst (dinocyst) event stratigraphy has been developed for the Cenomari?n is the Early Campanian based on a high-resolution palynological study of th = ' 1 . $\cdots$ nch borehole, together with the critical review of $>5000$ species records in the nu's.'shed literature.

The stratigraphic $r$ ¿sitions of the palynological event horizons at Trunch are precisely defined based on an integrated high-resolution framework of regional lithostratigraphic marker beds (including 5 bentonitic marls), macrofossil biostratigraphy, and carbon-isotope event (CIE) chemostratigraphy. This framework provides a basis for comparison with literature records, the majority of which lack comparable stratigraphic resolution. A total of 66 dinocyst bioevents from 49 species, and 1 bisaccate pollen bioevent are defined. These are judged to be of regional (NW Europe), Northern Hemisphere wide or, in four cases, of global stratigraphic significance. 
Absolute ages for the palynological events have been derived from a chronostratigraphic model based on radioisotopic and astrochronological ages of macrofossil biostratigraphic datum levels, global CIEs and a geomagnetic reversal. Individual dinocyst events, summarised in Fig. 22, are dated with a resolution of 10 $100 \mathrm{kyr}$, but the accuracy of these ages is typically judged to be around $\pm 500 \mathrm{kyr}$ due principally to uncertainties in the geological timescale.

Plots of the palaeogeographic distribution of key species, and critical appraisal of literature records, have allowed an assessment of the geographic extent of the dinocyst species and their associated events. Significant palaeolatitudinal patterns are apparent, with many species restricted to the Northern Hemisphere or $w$ specific climate belts; others are found to be cosmopolitan (Fig. 23). Some apna. an ly endemic taxa are newly described species, the geographic extent of wh $c_{1}$. wi.l become more apparent as further studies are conducted.

The 65 palynological events defined here ( 1 is. 22, Appendix B), including those interpreted to represent evolutionary first ar $\mathrm{D}^{\prime}$ :a ance and last appearance datum levels (FAD, LAD), together with ages d _ 'reı' for lowest and highest occurrences (LO, HO) in regional sections, are (from olde, to youngest):

1. Early Cenomanian (4 events): ( : 97.58 Ma LO frequent Sindridinium borealis (NW Europe); (2) 96.77 Ma LAJ sisphaeria munda (NW Europe); (3) 96.77 Ma HO frequent Sindridinium bort. 'lis (NW Europe); (4) 96.42 Ma LAD Sindridinium borealis (NW Europe).

2. Middle Cenomania - $1_{4}$ i vents): (5) 95.84 Ma LAD Hapsocysta peridictya (worldwide); (6, 9b.25 Ma HO common Epelidosphaeridia spinosa (N Hemisphere); (7) 95.15 Ma HO elidosphaeridia spinosa (UK) (N Hemisphere); (8) 94.95 Ma HO persistent Cribroperidinium? edwardsii (NW Europe).

3. Late Cenomanian (6 events): (9) 94.20 Ma LAD Epelidosphaeridia spinosa (N Hemisphere); (10) 94.20 Ma HO persistent/common Litosphaeridium siphoniphorum (worldwide); (11) 94.20 Ma HO common Sepispinula ambigua (NW Europe); (12) 94.10 Ma LAD Pterodinium crassimuratum (NW Europe); (13) 94.10 Ma LAD Wrevittia cassidata (N Hemisphere); (14) 94.00 Ma LAD Carpodinium obliquicostatum (NW Europe);

4. Early Turonian (6 events): (15) 93.60 Ma LO Heterosphaeridium difficile (USA) (southern N Hemisphere); (16) 93.40 Ma LAD Pervosphaeridium cenomaniense 
(worldwide); (17) 93.35 Ma FAD Canningia glomerata (N Hemisphere); (18) 93.35 Ma LO common Senoniasphaera turonica (NW Europe); (19) 93.30 Ma LAD Hapsocysta dictyota (N Hemisphere); (20) 93.05 Ma LO Heterosphaeridium difficile (UK) (NW Europe);

5. Middle Turonian (2 events): (21) 92.80 Ma LO common Sentusidinium devonense (NW Europe); (22) 91.90 Ma FAD Raetiaedinium truncigerum (N Hemisphere).

6. Late Turonian (7 events): (23) 91.04 Ma LO persistent Raetiaedinium truncigerum (N Hemisphere); (24) 90.16 Ma FAD Senoniasphaera filoreticulata (NW Europe); (25) 90.12 Ma reappearance Oligosphaeridium pulcherrimum (N Hemisphere); (26) 89.92 Ma HO persistent Cyclonephelium membranıь ^rum (NW Europe); (27) 89.88 Ma LAD Stephodinium coronatum (N Hemisphe، •) (28) 89.87 Ma HO persistent Senoniasphaera turonica (NW Europe); ( ?9', 89.76 Ma LAD Sentusidinium devonense (NW Europe).

7. Middle Coniacian (5 events): (30) 87.99 Ma Lu nersisent Heterosphaeridium verdieri (NW Europe); (31) 87.32 Ma HC $r$ el sistent Callaiosphaeridium asymmetricum (NW Europe); (32) :; 2, Ma LO frequent Senoniasphaera filoreticulata (NW Europe); (33) 8\%. 15 Ma FAD Spinidinium echinoideum (N Hemisphere); (34) 86.99 Ma LU rersisent Raphidodinium fucatum (NW Europe)

8. Early Santonian (5 events): ( $3^{\prime}$ ') $\mathbf{6 6 . 1 0}$ Ma FAD Spiniferites ramosus subsp. maeandriformis (NW Eurn $n^{\circ}$ ); (36) 86.06 Ma LO common Spinidinium echinoideum (NW Europe); (37) 85. -9 1.a temporary HO Senoniasphaera filoreticulata (NW Europe); (38) 85.95 Ma : 10 persistent Psaligonyaulax deflandrei (NW Europe?); (39) 85.77 Ma L? k....dinium rigidum (NW Europe?).

9. Middle Santonia:- 10 events): (40) 85.37 Ma FAD Chatangiella manumii (N Hemisphere); (41) 85.25 Ma FAD Cannosphaeropsis utinensis (N Hemisphere); (42) 85.25 Ma FAD Senoniasphaera protrusa (N Hemisphere); (43) 85.23 Ma LAD Spiniferites porosus (N Hemisphere); (44) 85.06 Ma LO Chatangiella eminens (NW Europe?); (45) 85.03 Ma HO Renidinium rigidum (NW Europe?); (46) 84.96 Ma reappearance Coronifera striolata (NW Europe?); (47) 84.96 Ma FAD Pervosphaeridium intervelum (NW Europe); (48) 84.94 Ma FAD Dimidium striatum (NW Europe); (49) 84.87 Ma LO Spiniferites jarvisii (NW Europe?).

10. Late Santonian (10 events): (50) 84.85 Ma FAD Odontochitina diducta (NW Europe?); (51) 84.81 Ma LO common Chatangiella eminens (NW Europe?); (52) 
84.73 Ma LO Odontochitina porifera (NW Europe); (53) 84.73 Ma LO

Trimuridinium whitenessense (NW Europe?); (54) 84.61 Ma HO common

Chatangiella eminens (NW Europe?); (55) 84.61 Ma LAD Heterosphaeridium difficile (worldwide); (56) 84.55 Ma LO Cordosphaeridium catherineae (NW Europe?); (57) 84.53 Ma FAD Rhynchodiniopsis saliorum (NW Europe); (58) 84.53 Ma LAD Scriniodinium campanula (N Hemisphere); (59) 84.52 Ma LAD Kleithriasphaeridium readei (N Hemisphere).

11. Early Campanian (6 events): (60) 84.15 Ma LO persistent Whitecliffia spinosa (NW Europe?); (61) 84.05 Ma FAD Alterbidinium ioannidesii (N Hemisphere); (62) 84.00 Ma LO persistent Spiniferites ramosus subsp. maear. Iriformis (NW Europe); (63) 83.48 Ma LO persisent Chatangiella manumii (N : Jer.lisphere); (64) 83.45 Ma LAD Dinopterygium alatum (N Hemisphere); (65) ¿2. $\mathbf{J}$ Ma LO Spiniferites multispinulus (NW Europe?).

Highest stratigraphic resolution (Fig. 22) is arhı ved for the Late Cenomanian Early Turonian, Late Turonian, Middle Coniac ia $\_$nd Santonian. Significant short-and long-term fluctuations in absolute dino y. $t$ andance, species richness and diversity in the Trunch succession correspond welı $\cdot$ stage and macrofossil zonal boundaries. It is anticipated that a series of abundanc 'events' may be characterised upon further testing to form the basis of an additior al biostratigraphic tool.

\section{Declaration of interests}

The authors declare tha ${ }^{2}$ th $y$ have no known competing financial interests or personal relationships that $\iota$ = ald have appeared to influence the work reported in this paper.

\section{Acknowledgments}

The manuscript benefitted from the insightful reviews of Dr Paul Dodsworth (Stratasolve Ltd) and Dr Henrik Nøhr-Hansen (GEUS Geological Survey of Denmark and Greenland) for which we are very grateful. Malcolm Jones (Palynological Laboratory Services, PLS) is thanked for the preparation of the palynological samples. This study was supported, in part, by a PhD studentship grant to MAP from Equinor Energy AS (previously Statoil ASA), and subsequent funding to IJ (contracts 4500867860 ; 4501936147; 4502299156; 4502311303). 


\section{Appendices}

\subsection{Appendix A. List of palynological taxa}

A complete list of organic walled dinoflagellate cyst taxa and associated palynomorphs recorded from the Cenomanian - Lower Campanian of the Trunch borehole is provided below. The classification of Fensome et al. (1993) is followed here, with references cited therein. The taxonomy of Williams et al. (2017) is employed (and cited as they appear in that work), with new combinations of Wood et al. (2016), Fensome et al. (2019) and Pearce and Williams (2018), and new species of Pearce (2018). Species marked with an asterisk $\left(^{*}\right)$ are illustrated on the range chart, Fig. 6. Stratigraphically significant species and selected other taxa ar illustrated in Plates 1 6.

DIVISION DINOFLAGELLATA (Bütschli 1885) Fen` viı a et al. 1993

SUBDIVISION DINOKARYOTA Fensome et al. 199?

CLASS DINOPHYCEAE Pascher 1914

SUBCLASS GYMNODINIPHYCEAE

ORDER PTYCHODISCALES

FAMILY PTYCHODISCACEAE

SUBFAMILY DINOGYMNIOIDEAE

Alisogymnium euclaense (Cook >n and Eisenack 1970a) Lentin and Vozzhennikova 1990

Dinogymnium acuminatum ${ }^{\mathrm{V}} \mathrm{Vu}^{+}{ }^{+}$et al. 1967 (Plate II, 4)

Dinogymnium denticulatım. (A.lberti 1961) Evitt et al. 1967

SUBCLASS PERIDINIPY' CIDAE Fensome et al. 1993

ORDER GONYAULACALES Taylor 1980

SUBORDER CLADOPYXIINEAE Fensome et al. 1993

Histiocysta palla Davey 1969

Microdinium bensonii subsp. pilatum Slimani 1994

Microdinium? crinitum Davey 1969

Microdinium distinctum Davey 1969

Microdinium ornatum Cookson and Eisenack 1960

Microdinium reticulatum Vozzhennikova 1967

Microdinium? sincfalensis Louwye 1995 
Microdinium spp. Cookson and Eisenack 1960

\section{FAMILY PAREODINIACEAE}

SUBFAMILY PAREODINIOIDEAE

Pareodinia ceratophora Deflandre 1947

\section{FAMILY UNCERTAIN}

Rhiptocorys veligera (Deflandre 1937) Lejeune-Carpentier and Sarjeant 1983 (Plate IV, 12)

\section{SUBORDER GONYAULACINEAE (Autonym) \\ FAMILY GONYAULACACEAE}

SUBFAMILY LEPTODINIOIDEAE Fensome et al. 1993

* Carpodinium obliquicostatum Cookson and Hugh es 1764 (Section 7.1.10.; Plate I, 6)

Conosphaeridium norfolkense Pearce 2018

* Kleithriasphaeridium readei (Davey and Will $\mathrm{m}$; 1966b) Davey and Verdier 1976

(Section 7.2.24.; Plate III, 6)

Leptodinium cancellatum Brideaux ana " cIntyre 1975

* Litosphaeridium siphoniphorum sui sp. glabrum Lucas-Clark 1984 (Section 7.1.6.)

* Litosphaeridium siphoniphorum $\mathrm{u}^{\prime} \mathrm{J}_{\mathrm{r}}$. siphoniphorum (Cookson and Eisenack 1958) Davey and Williams 1966 (¿acion 7.1.6.; Plate III, 9)

Litosphaeridium spp. Davey a ıd `’illiams 1966

Oligosphaeridium complex (W'ite 1842) Davey and Williams 1966

Oligosphaeridium pocul $\mathrm{m}$ เ' 'ain 1977

* Oligosphaeridium pui herrimum (Deflandre and Cookson 1955) Davey and Williams 1966 (Section 72 9.; Plate IV, 1)

* Rhynchodiniopsis saliorum Louwye 1995 (Section 7.4.22.; Plate V, 1)

SUBFAMILY CRIBROPERIDINIOIDEAE Fensome et al. 1993

Apteodinium deflandrei (Clarke and Verdier 1967) Lucas-Clark 1987 (Plate I, 2)

* Cordosphaeridium catherineae Pearce 2010 (Section 7.4.21.; Plate I, 10)

Cribroperidinium cooksoniae Norvick 1976

* Cribroperidinium? edwardsii (Cookson and Eisenack 1958) Davey 1969 (Section

\subsection{5.; Plate I, 12)}

Cribroperidinium wilsonii (Yun 1981) Poulsen 1996 (Plate II, 1)

Cribroperidinium spp. Neale and Sarjeant 1962 
Florentinia buspina (Davey and Verdier 1976) Duxbury 1980

Florentinia deanei (Davey and Williams 1966) Davey and Verdier 1973

Florentinia ferox (Deflandre 1937) Duxbury 1980

Florentinia radiculata (Davey and Williams 1966) Davey and Verdier 1973

Florentinia? torulosa (Davey and Verdier 1976) Lentin and Williams 1981

Florentinia spp. Davey and Verdier 1973

* Hapsocysta dictyota Davey 1979 (Section 7.2.5.; Plate II, 10)

* Hapsocysta peridictya (Eisenack and Cookson 1960) Davey 1979 (Section 7.1.3.; Plate II, 11)

Kallosphaeridium spp. De Coninck 1969

Spongodinium delitiense (Ehrenberg 1838) Deflandre 193f 'Dlate VI, 6)

\section{SUBFAMILY GONYAULACOIDEAE (Autonym)}

Achomosphaera crassipellis (Deflandre and Cookss n + 955) Stover and Evitt 1978

Achomosphaera cf. granulata Mao Shaozhi 1989

Achomosphaera ramulifera (Deflandre 1937) Ev it 1963

Achomosphaera regiensis Corradini 197\%

Achomosphaera sagena Davey and Wilı.' ns 1966

* Cannosphaeropsis utinensis Wetzeı 1933 (Section 7.4.7.; Plate I, 5)

Hystrichosphaeropsis ovum Deflan tre : 735 (Plate III, 4)

Hystrichosphaeropsis quasicribrata 'Wetzel 1961) Gocht 1976 (Plate III, 5)

Hystrichostrogylon membranı horum Agelopoulos 1964

Hystrichostrogylon robust: $m$ r earce 2010

* Psaligonyaulax def'rn ' 'rei jajeant 1966 (Section 7.4.4.; Plate IV, 6)

Pterodinium cingulatum subsp. cingulatum (Wetzel 1933) Below 1981

Pterodinium cingulatum subsp. granulatum (Clarke and Verdier 1967) Lentin and Williams 1981

Pterodinium cingulatum subsp. reticulatum (Davey and Williams 1966) Lentin and Williams 1981

Pterodinium? cornutum Cookson and Eisenack 1962

* Pterodinium crassimuratum (Davey and Williams 1966) Thurow etal. 1988 (Section 7.1.8.; Plate IV, 7)

* Spiniferites jarvisii Pearce 2010 (Section 7.4.15.; Plate VI, 2)

Spiniferites membranaceus (Rossignol 1964) Sarjeant 1970

* Spiniferites multispinulus Pearce 2010 (Section 7.5.4.; Plate VI, 3) 
* Spiniferites porosus (Manum and Cookson 1964) Harland 1973 (Section 7.4.9.; Plate VI, 4)

Spiniferites pseudofurcatus (Klumpp 1953) Sarjeant 1970

Spiniferites ramosus subsp. aquilis Pearce 2010

Spiniferites ramosus subsp. ginakrogiae Pearce 2018

Spiniferites ramosus subsp.gracilis (Davey and Williams 1966) Lentin and Williams 1973

Spiniferites ramosus subsp.granomembranaceus (Davey and Williams 1966) Lentin and Williams 1973

Spiniferites ramosus subsp. granosus (Davey and Williams 1966) Lentin and Williams 1973

* Spiniferites ramosus subsp. maeandriformis (Corradini 1072) Lentin and Williams 1975 (Section 7.4.1.; Plate VI, 5)

* Spiniferites ramosus subsp. ramosus (Ehrenberg 18?8) M; ntell 1854

Spiniferites ramosus subsp. reticulatus (Davey and '⿳r: lu ms 1966) Lentin and Williams 1973

Spiniferites twistringiensis (Maier 1959) Fensrme et al. 1990

Unipontadinium grande (Davey 1975) Wrer n . ors

* Wrevittia cassidata (Eisenack and Cc sks sn 1960) Helenes and Lucas-Clark 1997

(Section 7.1.9.; Plate VI, 12)

\section{SUBFAMILY UNCERTAIN}

* Callaiosphaeridium asymmet. - um (Deflandre and Courteville 1939) Davey and Williams 1966 (Sectiol. 7.3.2.; Plate I, 3)

Cometodinium obscurum Lefla 1 dre and Courteville 1939

Cometodinium whitei (I eflè ndre and Courteville 1939) Stover and Evitt 1978

Coronifera oceanica Cou'son and Eisenack 1958

* Coronifera striolata (Deflandre 1937) Stover and Evitt 1978 (Section 7.4.12.; Plate I, 11)

Hystrichodinium pulchrum Deflandre 1935 (Plate III, 3)

Kiokansium unituberculatum (Tasch in Tasch et al. 1964) Stover and Evitt 1978

* Pervosphaeridium cenomaniense (Norvick 1976) Below 1982 (Section 7.2.2.; Plate IV, 3)

* Pervosphaeridium intervelum Kirsch 1991 (Section 7.4.13.; Plate IV, 4)

Pervosphaeridium morgenrothii (Corradini 1973) Kirsch 1991

Pervosphaeridium pseudhystrichodinium (Deflandre 1937) Yun 1981 (Plate IV, 5)

Pervosphaeridium truncatum (Davey 1969) Below 1982

* Scriniodinium campanula Gocht 1959 (Section 7.4.23.; Plate V, 3) 
Sentusidinium sp. a Tocher and Jarvis 1987

* Sentusidinium devonense Pearce 2018 (Sections 7.2.6., 7.2.13.; Plate V, 8)

Sentusidinium euteiches (Davey 1969a) Wood et al. 2016

Sentusidinium ringnesiorum (Manum and Cookson 1964) Wood et al. 2016 (Plate V, 9)

* Stephodinium coronatum Deflandre 1936 (Section 7.2.11.; Plate VI, 7)

Surculosphaeridium belowii Yun 1981

Surculosphaeridium? cassospinum Yun 1981

Surculosphaeridium longifurcatum (Firtion 1952) Davey et al. 1966

Trichodinium castanea Deflandre 1935 ex Clarke and Verdier 1967 (Plate VI, 9)

FAMILY AREOLIGERACEAE Evitt 1963

* Canningia glomerata (Clarke and Verdier 1967) Fens נmı et al. 2019 (Section 7.2.3.; Plate I, 4)

Canningia reticulata Cookson and Eisenack 1960

Circulodinium distinctum (Deflandre and Cookson 1々: 5) Jansonius 1986

Cleistosphaeridium latoaculeum (Yun 1981) F ar ${ }_{1}$ s me et al. 2019

* Cyclonephelium membraniphorum Cor ¿. on and Eisenack 1962 (Section 7.2.10.; Plate II, 2)

Palynodinium helveticum Kirsch 19?1

* Senoniasphaera filoreticulata (Sli.n . ni 1994) Fensome et al. 2019 (Sections 7.2.8., 7.3.3., 7.4.3.; Plate V, 4)

* Senoniasphaera protrusa Clī $\mathrm{r}_{\mathrm{n}}{ }^{3}$ and Verdier 1967 (Section 7.4.8.; Plate V, 5)

* Senoniasphaera turonica (írossl 1990 ex Prössl 1992) Pearce et al. 2011 (Sections 7.2.4., 7.2.12; Plate : 6 - 7)

* Renidinium rigidun' P. inc', et al. 1999 (Sections 7.4.5., 7.4.11.; Plate IV, 10 - 11)

Tenua colliveri (Cooksor and Eisenack 1960) Helby 1987 (Plate VI, 8)

* Trimuridinium whitenessense (Prince et al. 2008) Fensome et al. 2019 (Section

7.4.18.; Plate VI, 10)

SUBORDER CERATIINEAE Fensome et al. 1993

FAMILY CERATIACEAE Willey and Hickson 1909

Odontochitina costata Alberti 1961

* Odontochitina diducta Pearce 2010 (Section 7.4.16.; Plate III, 10)

Odontochitina operculata (Wetzel 1933) Deflandre and Cookson 1955

* Odontochitina porifera Cookson 1956 (Section 7.4.17.; Plate III, 11)

Xenascus ceratioides (Deflandre 1937) Lentin and Williams 1973 
Xenascus perforatus (Vozzhennikova 1967) Yun 1981

Xenasus yunii Prince et al. 2008

Xenascus spp. Cookson and Eisenack 1969

SUBORDER GONIODOMINEAE Fensome et al. 1993

FAMILY GONIODOMACEAE Lindemann 1928

SUBFAMILY PYRODINIOIDEAE Fensome et al. 1993

* Dinopterygium alatum Cookson and Eisenack 1962) Fensome et al. 2009 (Section 7.5.3.; Plate II, 5)

Dinopterygium cladoides Deflandre 1935

Dinopterygium cf. cladoides Deflandre 1935

Dinopterygium tuberculatum (Eisenack and Cookson 10

Eisenackia crassitabulata Deflandre and Cookson 1955

Fetchamium prolixispinosum (Davey and Williams 19七 5) Pearce and Williams 2018 Hystrichosphaeridium? paracostatum Cookson an ^ Els ’nack 1974

Hystrichosphaeridium bowerbankii Davey anc ' Ji iams 1966 / recurvatum (White 1842) Lejeune-Carpentier 1940

Hystrichosphaeridium tubiferum subsץ. h' evispinum (Davey and Williams 1966) Lentin and Williams 1973

Hystrichosphaeridium tubiferum sl’. sp. ‘ubiferum (Ehrenberg 1838) Deflandre 1937

\section{SUBORDER UNCERTAIN}

FAMILY UNCERTAIN

Atopodinium haromens li ornas and Cox 1988

Caligodinium cf. aceras 'Ivanum and Cookson 1964) Lentin and Williams 1973

Cassiculosphaeridia alıu Pearce 2010

Cassiculosphaeridia reticulata Davey 1969a

Chlamydophorella discreta Clarke and Verdier 1967

Chlamydophorella nyei Cookson and Eisenack 1958

Codoniella campanulata (Cookson and Eisenack 1960) Downie and Sarjeant 1965

Dapsilidinium laminaspinosum (Davey and Williams 1966) Lentin and Williams 1981

Dapsilidinium? pumilum (Davey and Williams 1966) Lentin and Williams 1981

Dapsilidinium spp. Bujak et al. 1980

* Dimidium striatum (Clarke and Verdier 1967) Pearce 2010 (Section 7.4.14.; Plate II, 3)

Ellipsodinium rugulosum Clarke and Verdier 1967 (Plate II, 8) 
Exochosphaeridium arnace Davey and Verdier 1973

Exochosphaeridium majus (Clarke and Verdier 1967) Peyrot 2011

Exochosphaeridium majus (Clarke and Verdier 1967) Peyrot 2011 (robust type)

Exochosphaeridium phragmites Davey et al. 1966

Heterosphaeridium conjunctum Cookson and Eisenack 1968

* Heterosphaeridium difficile (Manum and Cookson 1964) Ioannides 1986 (7.2.1., 7.4.20; Plate II, 12, Plate III, 1)

Heterosphaeridium heteracanthum (Deflandre and Cookson 1955) Eisenack and Kjellström 1972

Heterosphaeridium spinaconjunctum Yun 1981

* Heterosphaeridium verdieri Yun 1981 (Section 7.3.1.; Plate:II, 2)

Membranilarnacia polycladiata Cookson and Eisenack in E'ser ack 1963

* Membranilarnacia wilsonii Pearce 2010

Montanarocysta aemiliana Corradini 1973

Neosphaerodictyon filosum Slimani 2003

* Raetiaedinium truncigerum (Deflandre 1937) ' 'irsch 1991 (Section 7.2.7.; Plate IV, 8)

* Raphidodinium fucatum Deflandre 1936? ieccion 7.3.5.; Plate IV, 9)

Tanyosphaeridium variecalamus Dave, ar d Williams 1966

Trigonopyxidia ginella (Cookson ar. J Eisenack 1960) Downie and Sarjeant 1965

Valensiella ovulum (Deflandre 194 ¿') Eisenack 1963

Wallodinium anglicum (Cookso . nu Hughes 1964) Lentin and Williams 1973

* Whitecliffia spinosa (Clarke nn Verdier 1967) Pearce 2010 (Section 7.5.1.; Plate VI, 11)

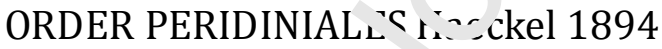

SUBORDER PERIDINI: ${ }^{N}$ ¿AE (Autonym)

FAMILY PERIDINIACEAE Ehrenberg 1831

OVOIDINIOIDEAE (Norris 1978) Bujak and Davies 1983

* Epelidosphaeridia spinosa Davey 1969a (Section 7.1.4.; Plate II, 9)

* Sindridinium borealis Nøhr-Hansen et al. 2018 (Section 7.1.1.; Plate V, 11 - 12)

SUBFAMILY PALAEOPERIDINIOIDEAE (Vozzhennikovia 1961) Bujak and Davies 1983

* Palaeohystrichophora infusorioides Deflandre 1935

* Palaeoperidinium pyrophorum (Ehrenberg 1838) Sarjeant 1967b (Plate IV, 2)

Subtilisphera pontis-mariae (Deflandre 1936) Lentin and Williams 1976 
SUBFAMILY DEFLANDREOIDEAE Bujak and Davies 1983

* Alterbidinium ioannidesii Pearce 2010 (Section 7.5.2.; Plate I, 1)

Alterbidinium spp. Lentin and Williams 1985

Amphidiadema spp. Cookson and Eisenack 1960

Chatangiella ditissima (McIntyre 1975) Lentin and Williams 1976 (Plate I, 7)

* Chatangiella eminens Pearce 2010 (Sections 7.4.10., 7.4.19.; Plate I, 8)

* Chatangiella manumii (Vozzhennikova 1967) Lentin and Williams 1976 (Section 7.4.6.; Plate I, 9)

Isabelidinium acuminatum (Cookson and Eisenack 1958) St vver and Evitt 1978

Isabelidinium cooksoniae (Alberti 1959) Lentin and Williarss 1 \77

Isabelidinium glabrum (Cookson and Eisenack 1969) Le-- +im und Williams 1977a

* Spinidinium echinoideum (Cookson and Eisenack 19 19 , I.entin and Williams 1976

(Sections 7.3.4., 7.4.2.; Plate VI, 1)

Trithyrodinium spp. Drugg 1967

SUBFAMILY OVOIDINIOIDEAE (Norris 197:') Bujak and Davies 1983

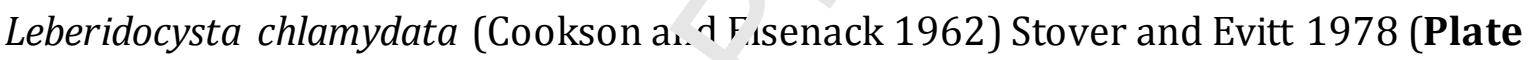
III, 7)

Leberidocysta defloccata (Davey and Vt:-dier 1973) Stover and Evitt 1978 (Plate III, 8)

\section{SUBCLASS UNCERTAIN}

ORDER UNCERTAIN

FAMILY UNCERTAIN

Prolixosphaeridium co.'rlum Davey 1969

\section{CLASS UNCERTAIN}

Disphaeria macropyla Cookson and Eisenack 1960

* Disphaeria munda (Davey and Verdier 1973) Norvick 1976 (Section 7.1.2.; Plate II, 6)

Downiesphaeridium? aciculare (Davey 1969) Islam 1993

Downiesphaeridium armatum (Deflandre 1937) Islam 1993 (Plate II, 7)

* Impletosphaeridium banterwickense Pearce 2018

* Sepispinula ambigua (Deflandre 1937) Masure in Fauconnier and Masure 2004

(Section 7.1.7.; Plate V, 10)

* Sepispinula pertusa (Davey 1969) Masure in Masure and Fauconnier 2004 
Additional palynomorphs:

Cymatiosphaera spp. Wetzel 1933 (prasinophyte)

Fromea amphora Cookson and Eisenack 1958 (acritarch)

Fromea fragilis (Cookson and Eisenack 1962) Stover and Evitt 1978 (acritarch)

Microforaminferal-test-lining

Palaeostomocystis reticulata Deflandre 1937 (acritarch)

Palambages morulosa Wetzel 1961 (colonial marine alga)

Paralecaniella indentata (Deflandre and Cookson 1955) Cookson and Eisenack 1970 (acritarch)

Pterospermella spp. Eisenack 1972 (prasinophyte)

* Rugubivesiculites rugosus Pierce 1961 (bisaccate pollen. I_..e V, 2)

Scolecodont (polychaete annelid jaw element)

Tarsisphaeridium geminiporatum Riegel 1974 (prāsilı ’phyte)

Bisaccate gymnosperm pollen

Veryhachium spp. Denuff 1954 (acritarch)

10.2 Appendix B. Summary of specic: bioevents

Appendix B. Age and

palaeogeographic extent of

bioevents

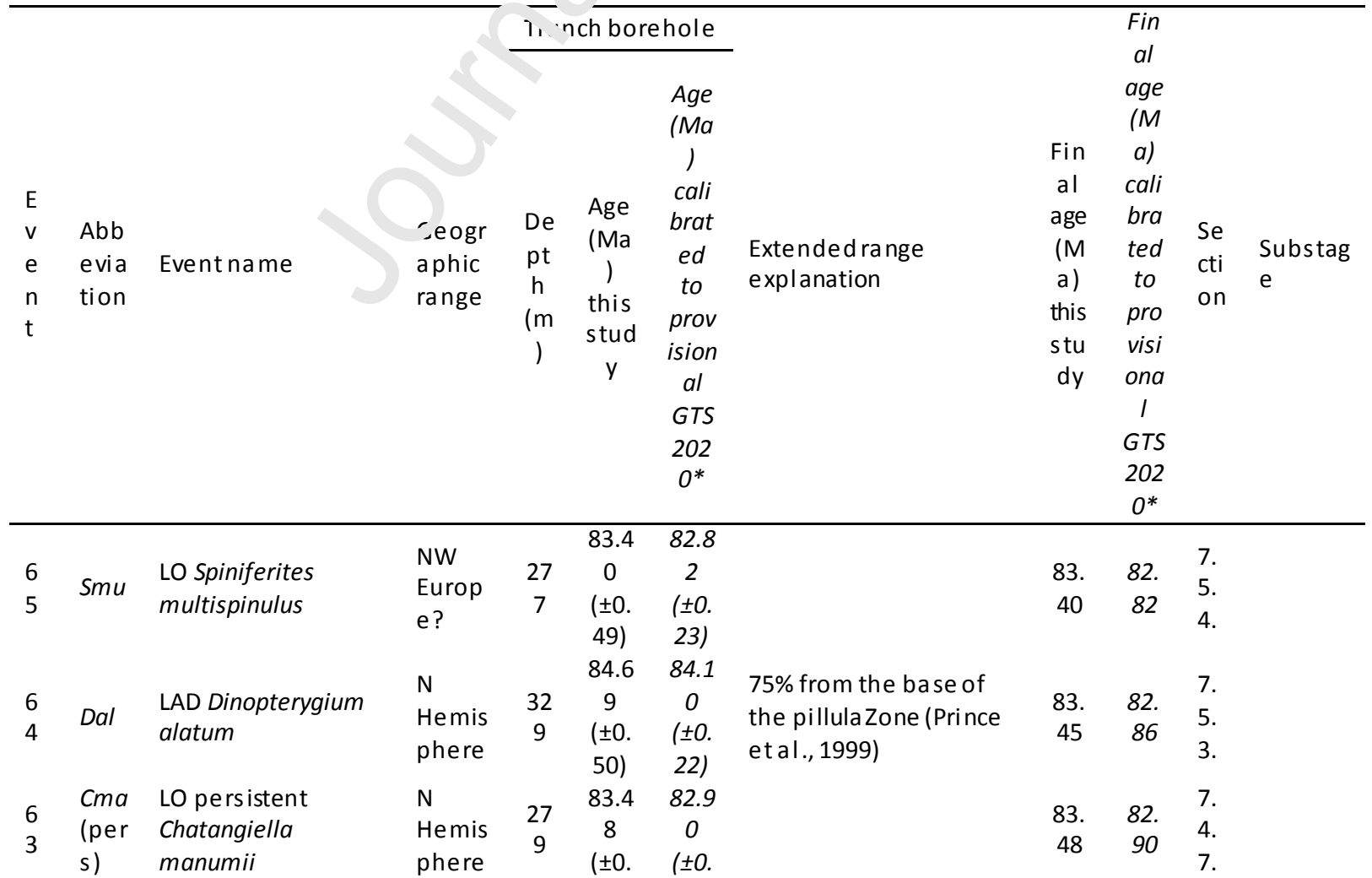




\begin{tabular}{|c|c|c|c|c|c|c|c|c|c|c|c|}
\hline & & & & & 50) & 23) & & & & & \\
\hline $\begin{array}{l}6 \\
2\end{array}$ & $\begin{array}{l}\text { Srm } \\
\text { (per } \\
\text { s) }\end{array}$ & $\begin{array}{l}\text { LO persistent } \\
\text { Spiniferites ramosus } \\
\text { maeandriformis }\end{array}$ & $\begin{array}{l}\text { NW } \\
\text { Europ } \\
\text { e }\end{array}$ & $\begin{array}{c}29 \\
6\end{array}$ & $\begin{array}{c}84.0 \\
0 \\
( \pm 0 \\
50)\end{array}$ & $\begin{array}{c}83.4 \\
1 \\
( \pm 0 \\
21)\end{array}$ & & $\begin{array}{l}84 . \\
00\end{array}$ & $\begin{array}{r}83 . \\
41\end{array}$ & $\begin{array}{l}7 . \\
4 . \\
1 .\end{array}$ & \\
\hline $\begin{array}{l}6 \\
1\end{array}$ & Aio & $\begin{array}{l}\text { FAD Alterbidinium } \\
\text { ioannidesii }\end{array}$ & $\begin{array}{l}\mathrm{N} \\
\text { Hemis } \\
\text { phere }\end{array}$ & $\begin{array}{c}29 \\
9\end{array}$ & $\begin{array}{c}84.0 \\
5 \\
( \pm 0 \\
50)\end{array}$ & $\begin{array}{l}83.4 \\
6 \\
( \pm 0 . \\
21)\end{array}$ & & $\begin{array}{l}84 . \\
05\end{array}$ & $\begin{array}{l}83 . \\
46\end{array}$ & $\begin{array}{l}7 . \\
5 . \\
2 .\end{array}$ & \\
\hline $\begin{array}{l}6 \\
0\end{array}$ & $\begin{array}{l}\text { Wsp } \\
\text { (per } \\
\text { s) }\end{array}$ & $\begin{array}{l}\text { LO persistent } \\
\text { Whitecliffia spinosa }\end{array}$ & $\begin{array}{l}\text { NW } \\
\text { Europ } \\
\text { e? }\end{array}$ & $\begin{array}{c}29 \\
2\end{array}$ & $\begin{array}{c}83.9 \\
1 \\
( \pm 0 . \\
50) \\
\end{array}$ & $\begin{array}{c}83.3 \\
2 \\
( \pm 0 . \\
22) \\
\end{array}$ & $\begin{array}{l}\text { mid-Santonian / } \\
\text { Campa nian Boundary } \\
\text { Event (Prince et al. 1999) }\end{array}$ & $\begin{array}{r}84 . \\
15\end{array}$ & $\begin{array}{r}83 . \\
56\end{array}$ & $\begin{array}{l}7 . \\
5 . \\
1 .\end{array}$ & $\begin{array}{l}\text { Early } \\
\text { Campan } \\
\text { ian }\end{array}$ \\
\hline $\begin{array}{l}5 \\
9\end{array}$ & Kre & $\begin{array}{l}\text { LAD } \\
\text { Kleithriasphaeridium } \\
\text { readei }\end{array}$ & $\begin{array}{l}\mathrm{N} \\
\text { Hemis } \\
\text { phere }\end{array}$ & $\begin{array}{c}32 \\
1\end{array}$ & $\begin{array}{c}84.5 \\
2 \\
( \pm 0 \\
50)\end{array}$ & $\begin{array}{c}83.9 \\
3 \\
( \pm 0 \\
22)\end{array}$ & & $\begin{array}{l}84 . \\
52\end{array}$ & $\begin{array}{r}83 . \\
93\end{array}$ & $\begin{array}{l}7 . \\
4 . \\
24 \\
.\end{array}$ & \\
\hline $\begin{array}{l}5 \\
8\end{array}$ & Sca & $\begin{array}{l}\text { LAD Scriniodinium } \\
\text { campanula }\end{array}$ & $\begin{array}{l}\mathrm{N} \\
\text { Hemis } \\
\text { phere }\end{array}$ & $\begin{array}{c}32 \\
2\end{array}$ & $\begin{array}{c}84.5 \\
3 \\
( \pm 0 . \\
50)\end{array}$ & $\begin{array}{c}83.9 \\
4 \\
( \pm 0 . \\
22)\end{array}$ & & $\begin{array}{r}84 . \\
53\end{array}$ & $\begin{array}{r}83 . \\
94\end{array}$ & $\begin{array}{l}7 . \\
4 . \\
23 \\
.\end{array}$ & \\
\hline $\begin{array}{l}5 \\
7\end{array}$ & $R s a$ & $\begin{array}{l}\text { FAD } \\
\text { Rhynchodiniopsis } \\
\text { saliorum }\end{array}$ & $\begin{array}{l}\text { NW } \\
\text { Europ } \\
\text { e }\end{array}$ & $\begin{array}{c}31 \\
2\end{array}$ & $\begin{array}{c}84.3 \\
7 \\
( \pm 0 . \\
46)\end{array}$ & $\begin{array}{c}83.7 \\
8 \\
( \pm 0 \\
18)\end{array}$ & $\begin{array}{l}\text { Ha .vn. Br, w ClE (Prince } \\
\text { e. I., 2'08); occurring } \\
\text { with_-riniodinium } \\
\text { sampanula }\end{array}$ & $\begin{array}{r}84 . \\
53\end{array}$ & $\begin{array}{r}83 . \\
94\end{array}$ & $\begin{array}{l}7 . \\
4 . \\
22 \\
.\end{array}$ & \\
\hline $\begin{array}{l}5 \\
6\end{array}$ & $C c a$ & $\begin{array}{l}\text { LO } \\
\text { Cordosphaeridium } \\
\text { catherineae }\end{array}$ & $\begin{array}{l}\text { NW } \\
\text { Europ } \\
\text { e? }\end{array}$ & $\begin{array}{c}32 \\
3\end{array}$ & $\begin{array}{l}84.5 \\
5 \\
1.0 . \\
b !\end{array}$ & $\begin{array}{l}3.9 \\
0 \\
( \pm 0 . \\
22)\end{array}$ & & $\begin{array}{r}84 . \\
55\end{array}$ & $\begin{array}{r}83 . \\
96\end{array}$ & $\begin{array}{l}7 . \\
4 . \\
21 \\
.\end{array}$ & \\
\hline $\begin{array}{l}5 \\
5\end{array}$ & Hdif & $\begin{array}{l}\text { LAD } \\
\text { Heterosphaeridium } \\
\text { difficile }\end{array}$ & $\begin{array}{l}\text { world } \\
\text { wide }\end{array}$ & & $\begin{array}{l}94.6 \\
1 \\
10 . \\
50)\end{array}$ & $\begin{array}{l}84.0 \\
2 \\
( \pm 0 . \\
27)\end{array}$ & & $\begin{array}{r}84 . \\
61\end{array}$ & $\begin{array}{r}84 . \\
02\end{array}$ & $\begin{array}{l}7 . \\
4 . \\
20 \\
.\end{array}$ & \\
\hline $\begin{array}{l}5 \\
4\end{array}$ & $\begin{array}{l}\text { Cem } \\
\bullet\end{array}$ & $\begin{array}{l}\text { HO common } \\
\text { Chatangiella } \\
\text { eminens }\end{array}$ & $\begin{array}{l}\text { NW } \\
\text { Eurc } \\
t^{?}\end{array}$ & $\begin{array}{c}32 \\
6\end{array}$ & $\begin{array}{c}84.6 \\
1 \\
( \pm 0 . \\
50)\end{array}$ & $\begin{array}{l}84.0 \\
2 \\
( \pm 0 . \\
27)\end{array}$ & & $\begin{array}{l}84 . \\
61\end{array}$ & $\begin{array}{r}84 . \\
02\end{array}$ & $\begin{array}{l}7 . \\
4 . \\
19 \\
.\end{array}$ & \\
\hline $\begin{array}{l}5 \\
3\end{array}$ & Twh & $\begin{array}{l}\text { LO Trimuradinium } \\
\text { whitenessense }\end{array}$ & $\begin{array}{l}\text { ivW } \\
\text { Europ } \\
\text { e? }\end{array}$ & $\begin{array}{c}30 \\
1\end{array}$ & $\begin{array}{c}84.0 \\
7 \\
( \pm 0 \\
50)\end{array}$ & $\begin{array}{c}83.4 \\
8 \\
( \pm 0 . \\
22)\end{array}$ & $\begin{array}{l}\text { midway between o1 and } \\
\text { o2 CIEs (Prince et al., } \\
\text { 2008) }\end{array}$ & $\begin{array}{l}84 . \\
73\end{array}$ & $\begin{array}{l}84 . \\
14\end{array}$ & $\begin{array}{l}7 . \\
4 . \\
18 \\
.\end{array}$ & \\
\hline $\begin{array}{l}5 \\
2\end{array}$ & Opo & $\begin{array}{l}\text { LO Odontochitina } \\
\text { porifera }\end{array}$ & $\begin{array}{l}\text { NW } \\
\text { Europ } \\
\text { e }\end{array}$ & $\begin{array}{c}32 \\
5\end{array}$ & $\begin{array}{c}84.5 \\
9 \\
( \pm 0 . \\
50)\end{array}$ & $\begin{array}{c}84.0 \\
0 \\
( \pm 0 . \\
22)\end{array}$ & $\begin{array}{l}\text { midway between o1 and } \\
\text { o2 ClEs (Prince et al., } \\
\text { 2008) }\end{array}$ & $\begin{array}{l}84 . \\
73\end{array}$ & $\begin{array}{r}84 . \\
14\end{array}$ & $\begin{array}{l}7 . \\
4 . \\
17 \\
.\end{array}$ & \\
\hline $\begin{array}{l}5 \\
1\end{array}$ & Cem & $\begin{array}{l}\text { LO common } \\
\text { Chatangiella } \\
\text { eminens }\end{array}$ & $\begin{array}{l}\text { NW } \\
\text { Europ } \\
\text { e? }\end{array}$ & $\begin{array}{c}33 \\
4\end{array}$ & $\begin{array}{c}84.8 \\
1 \\
( \pm 0 . \\
50)\end{array}$ & $\begin{array}{c}84.2 \\
2 \\
( \pm 0 . \\
22)\end{array}$ & & $\begin{array}{r}84 . \\
81\end{array}$ & $\begin{array}{r}84 . \\
22\end{array}$ & $\begin{array}{l}7 . \\
4 . \\
10 \\
.\end{array}$ & \\
\hline $\begin{array}{l}5 \\
0\end{array}$ & Odi & $\begin{array}{l}\text { FAD Odontochitina } \\
\text { diducta }\end{array}$ & $\begin{array}{l}\text { NW } \\
\text { Europ } \\
\text { e? }\end{array}$ & $\begin{array}{c}33 \\
6\end{array}$ & $\begin{array}{c}84.8 \\
5 \\
( \pm 0 \\
50) \\
\end{array}$ & $\begin{array}{c}84.2 \\
6 \\
( \pm 0 . \\
22) \\
\end{array}$ & & $\begin{array}{l}84 . \\
85\end{array}$ & $\begin{array}{l}84 . \\
26\end{array}$ & $\begin{array}{l}7 . \\
4 . \\
16 \\
.\end{array}$ & $\begin{array}{l}\text { earliest } \\
\text { Late } \\
\text { Santoni } \\
\text { an }\end{array}$ \\
\hline $\begin{array}{l}4 \\
9\end{array}$ & Sja & $\begin{array}{l}\text { LO Spiniferites } \\
\text { jarvisii }\end{array}$ & $\begin{array}{l}\text { NW } \\
\text { Europ } \\
\text { e? }\end{array}$ & $\begin{array}{c}33 \\
7\end{array}$ & $\begin{array}{c}84.8 \\
7 \\
( \pm 0 . \\
50)\end{array}$ & $\begin{array}{c}84.2 \\
8 \\
( \pm 0 . \\
22)\end{array}$ & & $\begin{array}{l}84 . \\
87\end{array}$ & $\begin{array}{l}84 . \\
28\end{array}$ & $\begin{array}{l}7 . \\
4 . \\
15\end{array}$ & \\
\hline
\end{tabular}




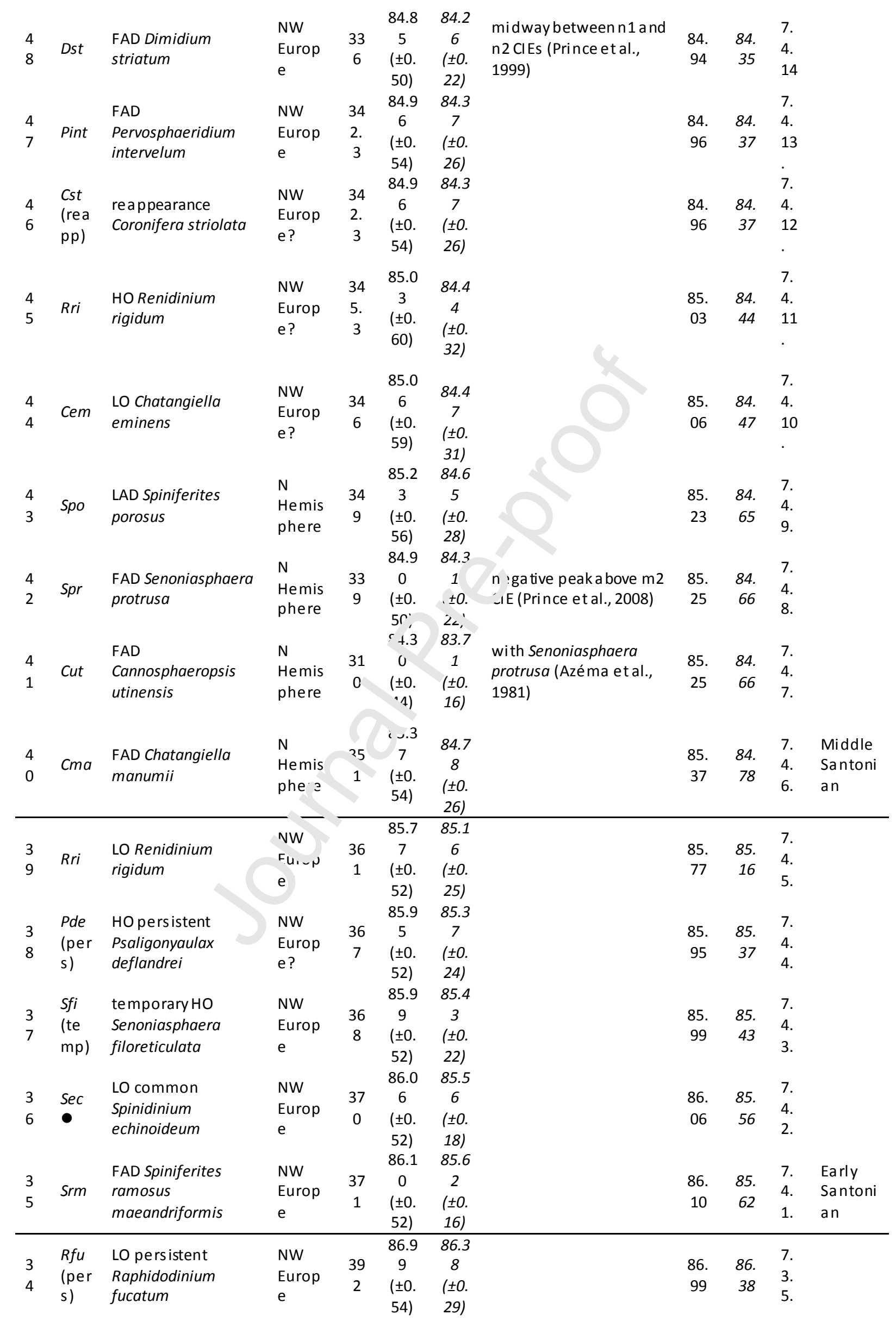




\begin{tabular}{|c|c|c|c|c|c|c|c|c|c|c|c|}
\hline $\begin{array}{l}3 \\
3\end{array}$ & $\mathrm{Sec}$ & $\begin{array}{l}\text { FAD Spinidinium } \\
\text { echinoideum }\end{array}$ & $\begin{array}{l}\mathrm{N} \\
\text { Hemis } \\
\text { phere }\end{array}$ & $\begin{array}{c}39 \\
3\end{array}$ & $\begin{array}{c}87.0 \\
5 \\
( \pm 0 . \\
54)\end{array}$ & $\begin{array}{c}86.4 \\
4 \\
( \pm 0 . \\
29)\end{array}$ & & $\begin{array}{l}87 . \\
05\end{array}$ & $\begin{array}{r}86 . \\
44\end{array}$ & $\begin{array}{l}7 . \\
3 . \\
4 .\end{array}$ & \\
\hline $\begin{array}{l}3 \\
2\end{array}$ & $\begin{array}{l}S f i \\
\bigcirc\end{array}$ & $\begin{array}{l}\text { LO frequent } \\
\text { Senoniasphaera } \\
\text { filoreticulata }\end{array}$ & $\begin{array}{l}\text { NW } \\
\text { Europ } \\
\text { e }\end{array}$ & $\begin{array}{c}38 \\
8\end{array}$ & $\begin{array}{c}86.7 \\
6 \\
( \pm 0 . \\
55)\end{array}$ & $\begin{array}{c}86.1 \\
6 \\
( \pm 0 . \\
28)\end{array}$ & $\begin{array}{l}\text { imme dately below j1 CIE } \\
\text { (Prince et al., 2008) }\end{array}$ & $\begin{array}{l}87 . \\
23\end{array}$ & $\begin{array}{r}86 . \\
63\end{array}$ & $\begin{array}{l}7 . \\
3 . \\
3 .\end{array}$ & \\
\hline $\begin{array}{l}3 \\
1\end{array}$ & $\begin{array}{l}\text { Cas } \\
\text { (per } \\
\text { s) }\end{array}$ & $\begin{array}{l}\text { HO persistent } \\
\text { Callaiosphaeridium } \\
\text { asymmetricum }\end{array}$ & $\begin{array}{l}\text { NW } \\
\text { Europ } \\
\text { e }\end{array}$ & $\begin{array}{c}39 \\
7\end{array}$ & $\begin{array}{c}87.3 \\
2 \\
( \pm 0 . \\
54)\end{array}$ & $\begin{array}{c}86.7 \\
2 \\
( \pm 0 . \\
29)\end{array}$ & & $\begin{array}{l}87 . \\
32\end{array}$ & $\begin{array}{r}86 . \\
72\end{array}$ & $\begin{array}{l}7 . \\
3 . \\
2 .\end{array}$ & \\
\hline $\begin{array}{l}3 \\
0\end{array}$ & $\begin{array}{l}\text { Hve } \\
\text { (per } \\
\text { s) }\end{array}$ & $\begin{array}{l}\text { LO persistent } \\
\text { Heterosphaeridium } \\
\text { verdieri }\end{array}$ & $\begin{array}{l}\text { NW } \\
\text { Europ } \\
\text { e }\end{array}$ & $\begin{array}{c}40 \\
6\end{array}$ & $\begin{array}{c}87.9 \\
9 \\
( \pm 0 . \\
52) \\
\end{array}$ & $\begin{array}{c}87.4 \\
6 \\
( \pm 0 . \\
30) \\
\end{array}$ & & $\begin{array}{l}87 . \\
99\end{array}$ & $\begin{array}{l}87 . \\
46\end{array}$ & $\begin{array}{l}7 . \\
3 . \\
1 .\end{array}$ & $\begin{array}{l}\text { Middle } \\
\text { Coniaci } \\
\text { an }\end{array}$ \\
\hline $\begin{array}{l}2 \\
9\end{array}$ & Sde & $\begin{array}{l}\text { LAD Sentusidinium } \\
\text { devonense }\end{array}$ & $\begin{array}{l}\text { NW } \\
\text { Europ } \\
\text { e }\end{array}$ & $\begin{array}{c}43 \\
0\end{array}$ & $\begin{array}{c}89.7 \\
6 \\
( \pm 0 . \\
43)\end{array}$ & $\begin{array}{c}89.4 \\
1 \\
( \pm 0 . \\
25)\end{array}$ & & $\begin{array}{l}89 . \\
76\end{array}$ & $\begin{array}{r}89 . \\
41\end{array}$ & $\begin{array}{l}7 . \\
2 . \\
13\end{array}$ & $\begin{array}{l}\text { lastest } \\
\text { Turonia } \\
\mathrm{n}\end{array}$ \\
\hline $\begin{array}{l}2 \\
8\end{array}$ & $\begin{array}{l}\text { Stu } \\
\text { (per } \\
\text { s) }\end{array}$ & $\begin{array}{l}\text { HO pers istent } \\
\text { Senoniasphaera } \\
\text { turonica }\end{array}$ & $\begin{array}{l}\text { NW } \\
\text { Europ } \\
\text { e }\end{array}$ & $\begin{array}{l}43 \\
2 . \\
2\end{array}$ & $\begin{array}{c}89.8 \\
7 \\
( \pm 0 . \\
46)\end{array}$ & $\begin{array}{c}89.5 \\
2 \\
( \pm 0 . \\
28)\end{array}$ & & $\begin{array}{l}89 . \\
87\end{array}$ & $\begin{array}{r}89 . \\
52\end{array}$ & $\begin{array}{l}7 . \\
2 . \\
12\end{array}$ & \\
\hline $\begin{array}{l}2 \\
7\end{array}$ & Sco & $\begin{array}{l}\text { LAD Stephodinium } \\
\text { coronatum }\end{array}$ & $\begin{array}{l}\mathrm{N} \\
\text { Hemis } \\
\text { phere }\end{array}$ & $\begin{array}{l}43 \\
2 . \\
4\end{array}$ & $\begin{array}{c}89.8 \\
8 \\
( \pm 0 . \\
47)\end{array}$ & $\begin{array}{c}89.5 \\
3 \\
1 \pm 0 \\
25\end{array}$ & & $\begin{array}{l}89 . \\
88\end{array}$ & $\begin{array}{r}89 . \\
53\end{array}$ & $\begin{array}{l}7 . \\
2 . \\
11 \\
.\end{array}$ & \\
\hline $\begin{array}{l}2 \\
6\end{array}$ & $\begin{array}{l}\text { Cme } \\
\text { (per } \\
\text { s) }\end{array}$ & $\begin{array}{l}\text { HO persistent } \\
\text { Cyclonephelium } \\
\text { membraniphorum }\end{array}$ & $\begin{array}{l}\text { NW } \\
\text { Europ } \\
\text { e }\end{array}$ & $\begin{array}{c}43 \\
3 . \\
3\end{array}$ & $\begin{array}{l}89.9 \\
? \\
+0 . \\
47\end{array}$ & $\begin{array}{l}9.5 \\
( \pm 0 . \\
29)\end{array}$ & & $\begin{array}{l}89 . \\
92\end{array}$ & $\begin{array}{r}89 . \\
57\end{array}$ & $\begin{array}{l}7 . \\
2 . \\
10 \\
.\end{array}$ & \\
\hline $\begin{array}{l}2 \\
5\end{array}$ & $\begin{array}{l}\text { Opu } \\
\text { (rea } \\
\text { pp) }\end{array}$ & $\begin{array}{l}\text { reappearance } \\
\text { Oligosphaeridium } \\
\text { pulcherrimum }\end{array}$ & $\begin{array}{l}\mathrm{N} \\
\text { Hemis } \\
\text { phere }\end{array}$ & 43 & $\begin{array}{c}90.1 \\
? \\
+9 . \\
+9)\end{array}$ & $\begin{array}{c}89.7 \\
7 \\
( \pm 0 . \\
30)\end{array}$ & & $\begin{array}{l}90 . \\
12\end{array}$ & $\begin{array}{l}89 . \\
77\end{array}$ & $\begin{array}{l}7 . \\
2 . \\
9 .\end{array}$ & \\
\hline $\begin{array}{l}2 \\
4\end{array}$ & Sfi & $\begin{array}{l}\text { FAD Senoniasphaera } \\
\text { filoreticulata }\end{array}$ & $\begin{array}{l}\text { NW } \\
\text { Eur } \rightarrow 0\end{array}$ & $\begin{array}{c}43 \\
9\end{array}$ & $\begin{array}{c}90.1 \\
6 \\
( \pm 0 \\
50)\end{array}$ & $\begin{array}{c}89.8 \\
1 \\
( \pm 0 . \\
30)\end{array}$ & & $\begin{array}{l}90 . \\
16\end{array}$ & $\begin{array}{l}89 . \\
81\end{array}$ & $\begin{array}{l}7 . \\
2 . \\
8 .\end{array}$ & \\
\hline $\begin{array}{l}2 \\
3\end{array}$ & $\begin{array}{l}\text { Rtr } \\
\text { (per } \\
\text { s) }\end{array}$ & $\begin{array}{l}\text { LO persistent } \\
\text { Raetiaedinium } \\
\text { truncigerum }\end{array}$ & $\begin{array}{l}H \geq \text { mis } \\
\text { phere }\end{array}$ & $\begin{array}{c}46 \\
7\end{array}$ & $\begin{array}{c}91.0 \\
4 \\
( \pm 0 . \\
53)\end{array}$ & $\begin{array}{c}90.6 \\
9 \\
( \pm 0 . \\
35) \\
\end{array}$ & & $\begin{array}{l}91 . \\
04\end{array}$ & $\begin{array}{r}90 . \\
69\end{array}$ & $\begin{array}{l}7 . \\
2 . \\
7 .\end{array}$ & $\begin{array}{l}\text { Late } \\
\text { Turonia } \\
\mathrm{n}\end{array}$ \\
\hline $\begin{array}{l}2 \\
2\end{array}$ & Rtr & $\begin{array}{l}\text { FAD Raetiaedinium } \\
\text { truncigerum }\end{array}$ & $\begin{array}{l}\mathrm{N} \\
\text { Hemis } \\
\text { phere }\end{array}$ & $\begin{array}{c}46 \\
7\end{array}$ & $\begin{array}{c}91.0 \\
4 \\
( \pm 0 . \\
53)\end{array}$ & $\begin{array}{c}90.6 \\
9 \\
( \pm 0 . \\
35)\end{array}$ & $\begin{array}{l}\text { below the Glynde CIE in } \\
\text { Czech Republic (Olde et } \\
\text { al., 2015) }\end{array}$ & $\begin{array}{r}91 . \\
90\end{array}$ & $\begin{array}{r}91 . \\
69\end{array}$ & $\begin{array}{l}7 . \\
2 . \\
7 .\end{array}$ & \\
\hline $\begin{array}{l}2 \\
1\end{array}$ & Sde & $\begin{array}{l}\text { LO common } \\
\text { Sentusidinium } \\
\text { devonense }\end{array}$ & $\begin{array}{l}\text { NW } \\
\text { Europ } \\
\text { e }\end{array}$ & $\begin{array}{c}46 \\
0\end{array}$ & $\begin{array}{c}90.9 \\
7 \\
( \pm 0 . \\
50)\end{array}$ & $\begin{array}{c}90.6 \\
2 \\
( \pm 0 . \\
32)\end{array}$ & $\begin{array}{l}\text { midway between } \mathrm{d} 1 \text { and } \\
\mathrm{d} 2 \mathrm{ClEs} \text { (Pearce, 2000) }\end{array}$ & $\begin{array}{r}92 . \\
80\end{array}$ & $\begin{array}{r}92 . \\
79\end{array}$ & $\begin{array}{l}7 . \\
2 . \\
6 .\end{array}$ & $\begin{array}{l}\text { Middle } \\
\text { Turonia } \\
\mathrm{n}\end{array}$ \\
\hline $\begin{array}{l}2 \\
0\end{array}$ & $\begin{array}{l}\text { Hdif } \\
\text { (UK) }\end{array}$ & $\begin{array}{l}\text { LO } \\
\text { Heterosphaeridium } \\
\text { difficile (UK) }\end{array}$ & $\begin{array}{l}\text { NW } \\
\text { Europ } \\
\text { e }\end{array}$ & $\begin{array}{c}46 \\
2\end{array}$ & $\begin{array}{c}90.9 \\
9 \\
( \pm 0 . \\
51)\end{array}$ & $\begin{array}{c}90.6 \\
4 \\
( \pm 0 . \\
33)\end{array}$ & $\begin{array}{l}\text { imme diately a bove c2 } \\
\text { CIE (UK; Pea rce et a I., } \\
\text { 2003) }\end{array}$ & $\begin{array}{r}93 . \\
05\end{array}$ & $\begin{array}{r}93 . \\
05\end{array}$ & $\begin{array}{l}7 . \\
2 . \\
1 .\end{array}$ & \\
\hline $\begin{array}{l}1 \\
9\end{array}$ & Hdic & $\begin{array}{l}\text { LAD Hapsocysta } \\
\text { dictyota }\end{array}$ & $\begin{array}{l}\mathrm{N} \\
\text { Hemis } \\
\text { phere }\end{array}$ & $\begin{array}{l}50 \\
4 . \\
3\end{array}$ & $\begin{array}{c}95.6 \\
8 \\
( \pm 0 . \\
41)\end{array}$ & $\begin{array}{c}95.6 \\
2 \\
( \pm 0 . \\
50)\end{array}$ & $\begin{array}{l}\text { Bed } 103 \text { (lowermost } M . \\
\text { nodosoides Zone), } \\
\text { Pueblo(USA; } \\
\text { Dods worth, 2000) }\end{array}$ & $\begin{array}{r}93 . \\
30\end{array}$ & $\begin{array}{r}93 . \\
30\end{array}$ & $\begin{array}{l}7 . \\
2 . \\
5 .\end{array}$ & \\
\hline 1 & Stu & LO common & NW & 46 & 91.0 & 90.6 & base M. nodosoides & 93. & 93. & 7. & \\
\hline
\end{tabular}




\begin{tabular}{|c|c|c|c|c|c|c|c|c|c|c|c|}
\hline 8 & $\bullet$ & $\begin{array}{l}\text { Senoniasphaera } \\
\text { turonica }\end{array}$ & $\begin{array}{l}\text { Europ } \\
\text { e }\end{array}$ & 5 & $\begin{array}{c}1 \\
( \pm 0 \\
52)\end{array}$ & $\begin{array}{l}6 \\
( \pm 0 . \\
34)\end{array}$ & $\begin{array}{l}\text { Zone (Pearce et al., } \\
\text { 2009) }\end{array}$ & 35 & 35 & $\begin{array}{l}2 . \\
4 .\end{array}$ & \\
\hline $\begin{array}{l}1 \\
7\end{array}$ & $\mathrm{Cgl}$ & $\begin{array}{l}\text { FAD Canningia } \\
\text { glomerata }\end{array}$ & $\begin{array}{l}\mathrm{N} \\
\text { Hemis } \\
\text { phere }\end{array}$ & $\begin{array}{c}45 \\
9\end{array}$ & $\begin{array}{c}90.9 \\
6 \\
( \pm 0 \\
50)\end{array}$ & $\begin{array}{c}90.6 \\
1 \\
( \pm 0 . \\
32)\end{array}$ & $\begin{array}{l}\text { wase } M . \text { nodosoides } \\
\text { Zone (FitzPatrick, 1995) }\end{array}$ & $\begin{array}{l}93 . \\
35\end{array}$ & $\begin{array}{r}93 . \\
35\end{array}$ & $\begin{array}{l}7 . \\
2 . \\
3 .\end{array}$ & \\
\hline $\begin{array}{l}1 \\
6\end{array}$ & Pce & $\begin{array}{l}\text { LAD } \\
\text { Pervosphaeridium } \\
\text { cenomaniense }\end{array}$ & $\begin{array}{l}\text { world } \\
\text { wide }\end{array}$ & $\begin{array}{l}50 \\
7 . \\
9\end{array}$ & $\begin{array}{c}97.0 \\
1 \\
( \pm 0 . \\
51)\end{array}$ & $\begin{array}{c}97.3 \\
2 \\
( \pm 0 . \\
56)\end{array}$ & $\begin{array}{l}\text { between the Compton } \\
\text { Pebble Marl and Gun } \\
\text { Gardens Marl } 1 \text { (UK; } \\
\text { Pearce et al., 2009) }\end{array}$ & $\begin{array}{r}93 . \\
40\end{array}$ & $\begin{array}{r}93 . \\
40\end{array}$ & $\begin{array}{l}7 . \\
2 . \\
2 .\end{array}$ & \\
\hline $\begin{array}{l}1 \\
5\end{array}$ & $\begin{array}{l}\text { Hdif } \\
\text { (US } \\
\text { A) }\end{array}$ & $\begin{array}{l}\text { LO } \\
\text { Heterosphaeridium } \\
\text { difficile (USA) }\end{array}$ & $\begin{array}{l}\text { southe } \\
\text { rn N } \\
\text { Hemis } \\
\text { phere }\end{array}$ & & & & $\begin{array}{l}\text { Bed 95, Pueblo (USA; } \\
\text { Dods worth, 2000) }\end{array}$ & $\begin{array}{r}93 . \\
60\end{array}$ & $\begin{array}{r}93 . \\
60\end{array}$ & $\begin{array}{l}7 . \\
2 . \\
1 .\end{array}$ & $\begin{array}{l}\text { earliest } \\
\text { Turonia } \\
\mathrm{n}\end{array}$ \\
\hline $\begin{array}{l}1 \\
4\end{array}$ & Cob & $\begin{array}{l}\text { LAD Carpodinium } \\
\text { obliquicostatum }\end{array}$ & $\begin{array}{l}\text { NW } \\
\text { Europ } \\
\text { e }\end{array}$ & $\begin{array}{l}50 \\
3 . \\
8\end{array}$ & $\begin{array}{c}95.5 \\
3 \\
( \pm 0 . \\
39)\end{array}$ & $\begin{array}{c}95.4 \\
7 \\
( \pm 0 . \\
47)\end{array}$ & $\begin{array}{l}\text { mid-N. juddii Znne } \\
\text { (Mars hall a nd L- -ten, } \\
\text { 1988) }\end{array}$ & $\begin{array}{l}94 . \\
00\end{array}$ & $\begin{array}{r}94 . \\
00\end{array}$ & $\begin{array}{l}. \\
1 . \\
10 \\
.\end{array}$ & $\begin{array}{l}\text { latest } \\
\text { Cenoma } \\
\text { nian }\end{array}$ \\
\hline $\begin{array}{l}1 \\
3\end{array}$ & $W c a$ & $\begin{array}{l}\text { LAD Wrevittia } \\
\text { cassidata }\end{array}$ & $\begin{array}{l}\mathrm{N} \\
\text { Hemis } \\
\text { phere }\end{array}$ & $\begin{array}{l}50 \\
4 . \\
3\end{array}$ & $\begin{array}{c}95.6 \\
8 \\
( \pm 0 . \\
41)\end{array}$ & $\begin{array}{l}95.6 \\
2 \\
( \pm 0 . \\
50)\end{array}$ & $\begin{array}{l}\text { Bed 78, } P_{1} \text { Ln' }^{\prime} \supset \text { (USA; } \\
\text { Dodswo. th, } 2(30)\end{array}$ & $\begin{array}{r}94 . \\
10\end{array}$ & $\begin{array}{r}94 . \\
10\end{array}$ & $\begin{array}{l}7 . \\
1 . \\
9\end{array}$ & \\
\hline $\begin{array}{l}1 \\
2\end{array}$ & Pcr & $\begin{array}{l}\text { LAD Pterodinium } \\
\text { crassimuratum }\end{array}$ & $\begin{array}{l}\text { NW } \\
\text { Europ } \\
\text { e }\end{array}$ & $\begin{array}{l}50 \\
3 . \\
8\end{array}$ & $\begin{array}{c}95.5 \\
3 \\
( \pm 0 . \\
39)\end{array}$ & $\begin{array}{l}95.4 \\
7 \\
( \pm 0 . \\
47)\end{array}$ & $\begin{array}{l}\text { uk perr, ost Plenus Marl } \\
\mathrm{Be}_{\mathrm{L}} \mathrm{Q}(\mathrm{r} \text { earce et al., } \\
\left.2^{\prime}, 09\right)\end{array}$ & $\begin{array}{l}94 . \\
10\end{array}$ & $\begin{array}{r}94 . \\
10\end{array}$ & $\begin{array}{l}7 . \\
1 . \\
8 .\end{array}$ & \\
\hline $\begin{array}{l}1 \\
1\end{array}$ & Sam & $\begin{array}{l}\text { HO common } \\
\text { Sepispinula ambigua }\end{array}$ & $\begin{array}{l}\text { NW } \\
\text { Europ } \\
\text { e }\end{array}$ & $\begin{array}{l}50 \\
4 . \\
8\end{array}$ & $\begin{array}{c}95.8 \\
4 \\
( \pm 2 \\
4)\end{array}$ & $\begin{array}{c}95.7 \\
9 \\
(2 \\
54)\end{array}$ & $\begin{array}{l}\text { P enus Marl Bed } 6 \\
\text { (Dodsworth, 2000; } \\
\text { Pearce et al., 2009) }\end{array}$ & $\begin{array}{l}94 . \\
20\end{array}$ & $\begin{array}{r}94 . \\
20\end{array}$ & $\begin{array}{l}7 . \\
1 . \\
7 .\end{array}$ & \\
\hline $\begin{array}{l}1 \\
0\end{array}$ & $\begin{array}{l}\text { Lsi } \\
\text { (per } \\
\text { s) } \bullet\end{array}$ & $\begin{array}{l}\text { HO } \\
\text { persistent/common } \\
\text { Litosphaeridium } \\
\text { siphoniphorum }\end{array}$ & $\begin{array}{l}\text { world } \\
\text { wide }\end{array}$ & $\begin{array}{l}50 \\
4 .\end{array}$ & $\begin{array}{l}95.6 \\
8 \\
10 . \\
11)\end{array}$ & $\begin{array}{l}95.6 \\
2 \\
( \pm 0 \\
50)\end{array}$ & $\begin{array}{l}\text { Plenus Marl Bed } 6 \\
\text { (Pearce et al., 2009) }\end{array}$ & $\begin{array}{l}94 . \\
20\end{array}$ & $\begin{array}{l}94 . \\
20\end{array}$ & $\begin{array}{l}7 . \\
1 . \\
6 .\end{array}$ & \\
\hline 9 & $E s p$ & $\begin{array}{l}\text { LAD } \\
\text { Epelidosphaeridia } \\
\text { spinosa }\end{array}$ & $\begin{array}{l}\mathrm{N} \\
\text { Hemis } \\
\text { phe e }\end{array}$ & & & & $\begin{array}{l}\text { from La molda and Ma o } \\
\text { (1999) }\end{array}$ & $\begin{array}{l}94 . \\
20\end{array}$ & $\begin{array}{r}94 . \\
20\end{array}$ & $\begin{array}{l}7 . \\
1 . \\
4 .\end{array}$ & \\
\hline 8 & $\begin{array}{l}\text { C?e } \\
d \\
\text { (per } \\
\text { s) }\end{array}$ & $\begin{array}{l}\text { HO persistent } \\
\text { Cribroperidinium? } \\
\text { edwardsii }\end{array}$ & $\begin{array}{l}\text { N." } \\
\text { Furop } \\
\text { a }\end{array}$ & $\begin{array}{l}50 \\
6 . \\
4\end{array}$ & $\begin{array}{c}96.4 \\
2 \\
( \pm 0 . \\
50)\end{array}$ & $\begin{array}{c}96.4 \\
8 \\
( \pm 0 \\
60)\end{array}$ & below b2 ClE (Figure 11) & $\begin{array}{l}94 . \\
95\end{array}$ & $\begin{array}{r}94 . \\
95\end{array}$ & $\begin{array}{l}7 . \\
1 . \\
5 .\end{array}$ & \\
\hline 7 & $\begin{array}{l}E s p \\
\text { (UK) }\end{array}$ & $\begin{array}{l}\text { HO } \\
\text { Epelidosphaeridia } \\
\text { spinosa (UK) }\end{array}$ & $\begin{array}{l}\text { Hemis } \\
\text { phere }\end{array}$ & $\begin{array}{l}50 \\
4 . \\
3\end{array}$ & $\begin{array}{c}95.6 \\
8 \\
( \pm 0 . \\
41) \\
\end{array}$ & $\begin{array}{c}95.6 \\
2 \\
( \pm 0 . \\
50) \\
\end{array}$ & $\begin{array}{l}\text { imme dately below b1 } \\
\mathrm{CIE} \text { (Figure 11) }\end{array}$ & $\begin{array}{c}95 . \\
15\end{array}$ & $\begin{array}{r}95 . \\
15\end{array}$ & $\begin{array}{l}7 . \\
1 . \\
4 .\end{array}$ & $\begin{array}{l}\text { Late } \\
\text { Cenoma } \\
\text { nian }\end{array}$ \\
\hline 6 & $\begin{array}{l}s p \\
\bigcirc / \\
\bullet\end{array}$ & $\begin{array}{l}\text { HO common } \\
\text { Epelidosphaeridia } \\
\text { spinosa }\end{array}$ & $\begin{array}{l}\mathrm{N} \\
\text { Hemis } \\
\text { phere }\end{array}$ & & & & $\begin{array}{l}\text { immedately below } \\
\text { Jukes-Brownei } \mathrm{ClE} \\
\text { (Figure 11) }\end{array}$ & $\begin{array}{c}95 . \\
35\end{array}$ & $\begin{array}{r}95 . \\
35\end{array}$ & $\begin{array}{l}7 . \\
1 . \\
4 .\end{array}$ & \\
\hline 5 & Hpe & $\begin{array}{l}\text { LAD Hapsocysta } \\
\text { peridictya }\end{array}$ & $\begin{array}{l}\text { world } \\
\text { wide }\end{array}$ & $\begin{array}{l}50 \\
4 . \\
8\end{array}$ & $\begin{array}{c}95.8 \\
4 \\
( \pm 0 . \\
44)\end{array}$ & $\begin{array}{c}95.7 \\
9 \\
( \pm 0 . \\
54)\end{array}$ & & $\begin{array}{l}95 . \\
84\end{array}$ & $\begin{array}{r}95 . \\
79\end{array}$ & $\begin{array}{l}7 . \\
1 . \\
3 .\end{array}$ & $\begin{array}{l}\text { Middle } \\
\text { Cenoma } \\
\text { nian }\end{array}$ \\
\hline 4 & Sbo & $\begin{array}{l}\text { LAD Sindridinium } \\
\text { borealis }\end{array}$ & $\begin{array}{l}\text { NW } \\
\text { Europ } \\
\text { e }\end{array}$ & $\begin{array}{l}50 \\
6 . \\
4\end{array}$ & $\begin{array}{c}96.4 \\
2 \\
( \pm 0 . \\
50)\end{array}$ & $\begin{array}{c}96.4 \\
8 \\
( \pm 0 . \\
60)\end{array}$ & & $\begin{array}{l}96 . \\
42\end{array}$ & $\begin{array}{r}96 . \\
48\end{array}$ & $\begin{array}{l}7 . \\
1 . \\
1 .\end{array}$ & \\
\hline 3 & $\begin{array}{l}D m \\
u\end{array}$ & $\begin{array}{l}\text { LAD Disphaeria } \\
\text { munda }\end{array}$ & $\begin{array}{l}\text { NW } \\
\text { Europ } \\
\text { e }\end{array}$ & $\begin{array}{l}50 \\
7 . \\
3\end{array}$ & $\begin{array}{c}96.7 \\
7 \\
( \pm 0 . \\
51)\end{array}$ & $\begin{array}{c}96.9 \\
6 \\
( \pm 0 \\
58)\end{array}$ & & $\begin{array}{l}96 . \\
77\end{array}$ & $\begin{array}{r}96 . \\
96\end{array}$ & $\begin{array}{l}7 . \\
1 . \\
2 .\end{array}$ & \\
\hline 2 & $\begin{array}{l}\text { Sbo } \\
0\end{array}$ & $\begin{array}{l}\text { HO frequent } \\
\text { Sindridinium borealis }\end{array}$ & $\begin{array}{l}\text { NW } \\
\text { Europ }\end{array}$ & $\begin{array}{l}50 \\
7 .\end{array}$ & $\begin{array}{c}96.7 \\
7\end{array}$ & $\begin{array}{c}96.9 \\
6\end{array}$ & & $\begin{array}{l}96 . \\
77\end{array}$ & $\begin{array}{l}96 . \\
96\end{array}$ & $\begin{array}{l}7 . \\
1 .\end{array}$ & \\
\hline
\end{tabular}


51) 58)

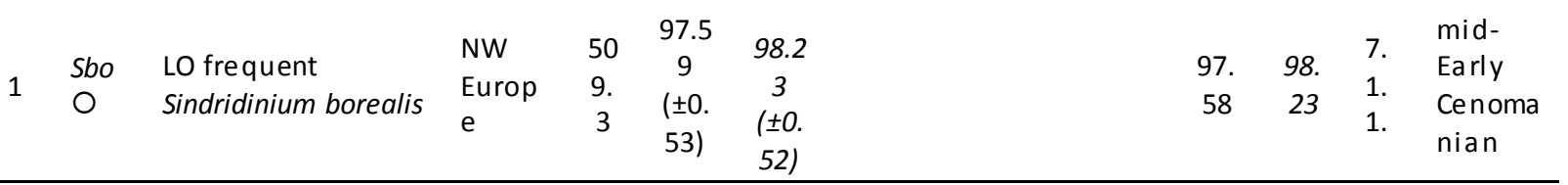

pers = persistent; reapp = reappearence; $\mathrm{LO}=$ lowest occurre nce; $\mathrm{HO}=$ highest occurrence;

$F A D=$ first a ppearance datum; $L A D=$ last a ppearance datum. Abundances: open circles = frequent; filled circles $=$ common

*The proposed GTS2020 a dopts the following a ges for Late Cretace ous stage bases (F. Gradstein pers. comm., September 2019): Cenomanian 100.5 $\pm 0.1 \mathrm{Ma}$; Turonian 93.9 $\pm 0.2 \mathrm{Ma}$; Coniacian $89.4 \pm 0.2 \mathrm{Ma}$; Santonian 85.7 \pm 0.1 ; Ca mpa nian $83.6 \pm 0.1 ;$ Ma a strichtian $72.2 \pm 0.2$.

The se ages have been substituted in our a ge model to derive the GTS2020-calibrated a ges presented here. Age differences between values derived from the two models va ry greatly, but all lie within error of each other. 


\section{References}

Abdel-Kireem, M.R., Schrank, E., Samir, A.M., Ibrahim, M.I.A., 1996. Cretaceous palaeoecology, palaeogeography and palaeoclimatology the northern Western Desert Egypt. Journal of African Earth Sciences 22, 93-112.

Adams, D.D., Hurtgen, M.T., Sageman, B.B., 2010. Volcanic triggering of a biogeochemical cascade during Oceanic Anoxic Event 2. Nature Geoscience 3, 201-204.

Aguirre-Urreta, M.B., Concheyro, A., Lorenzo, M., Ottone, E.G., Rawson, P.F., 1999. Advances in the biostratigraphy of the Agrio Formation (Lower Cretaceous) of the Neuquén Basin, Argentina: ammonites, palynomorphs and calcareous nannofossils. Palaeogeography, Palaeoclimatology, Palaeoecology 150, 33-47.

Al-Ameri, T.K., Al-Najar, T.K., Batten, D.J., 2001. Palynostratigraphy and palynofacies indications of depositional environments and source $r$ tential for hydrocarbons: the Mid Cretaceous Nahr Umr and lower Mauddud Frnma 'ions, Iraq. Cretaceous Research 22,735-742.

Andrews, J.E., Kendall, A.C., Hall, A., 2015. Microbial cru st w th Frutexites(?) and iron staining in chalks: Albian - Cenomanian bound, ry, Hunstanton, UK. Geological Magazine 152,1-11.

Antonescu, E., Foucher, J.-C., Odin, G.S., 2001a. Din sfic sellate cysts from the transition at Tercis les Bains (Landes, France). In: Od an r.S. (Ed.), The CampanianMaastrichtian Stage Boundary: charac $e_{1}$-c.cion at Tercis les Bains (France): correlation with Europe and othe $\omega$ n inents. IUGS Special Publication

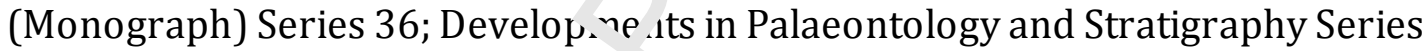
19, Amsterdam, pp. 235-252

Antonescu, E., Foucher, J.-C., Odin, S. S., schiøler, P., Siegl-Farkas, A., Wilson, G.J., 2001b. Dinoflagellate cysts in the Cán p: nian-Maastrichtian succession of Tercis les Bains (Landes, France), a synth(:sis. In: Odin, G.S. (Ed.), The Campanian-Maastrichtian Stage Boundary: charar er - tion at Tercis les Bains (France): correlation with Europe and other Con: int.:ts. IUGS Special Publication (Monograph) Series 36; Developments in Paı o' ıtology and Stratigraphy Series 19, Amsterdam, pp. 253264.

Arai, M., 1994. Dinoflas llates of the Late Cretaceous (Turonian - Maastrichtian) Continental She!c, joutheast Brazil. Boletim do Simpósio Sobre o Cretáceo do Brasil 3, 59-62.

Arai, M., Masure, E., 1997. The dinoflagellates of the Vraconian of the Campos Basin, (Brasil), paper presented at Second Annual Conference of IGCP Project 381. (South Atlantic Mesozoic Correlations).

Århus, N., 1991. Dinoflagellate cyst stratigraphy of some Aptian and sections from North Greenland, southeastern Spitsbergen and the Barents Sea. Cretaceous Research $12,209-225$.

Askin, R.A., 1988. The Campanian - Paleocene palynological succession of Seymour and adjacent islands, northeastern Antarctic Peninsula In: Feldmann, R.M., Woodburne, M.O. (Ed.), Geology and palaeontology of Seymour Island, Antarctic Peninsula. Geological Society of America, Memoir 169, 131-153. 
Askin, R.A., Elliot, D.H., Stilwell, J.D., Zinsmeister, W.J., 1991. Stratigraphy and paleontology of Campanian and Eocene sediments, Cockburn Island, Antarctic Peninsula. Journal of South American Earth Sciences 4, 99-117.

Aurisano, R.W., 1989. Upper Cretaceous dinoflagellate biostratigraphy of the subsurface Atlantic Coastal Plain of New Jersey and Delaware, U.S.A. Palynology 13, 143-179.

Azéma, C., Fauconnier, D., Viaud, J.M., 1981. Microfossils from the Upper Cretaceous of Vendée (France). Review of Palaeobotany and Palynology 35, 237-281.

Backhouse, J., 2003. Appendix 2: Palynology. In: Dixon, M., Haig, D.W., Mory, A.J., Backhouse, J., Ghori, K.A.R., Howe, R., Morris, P.A., GSWA Edaggee 1 Well completion report, (interpretive) Gascoyne Platform, Southern Carnarvon Basin Western Australia.). Geological Survey of Western Australia. Record 2003, 43-49.

Bailey, H.W., Gale, A.S., Mortimore, R.N., Swiecicki, A., Wooc, r.J., 1983. The ConiacianMaastrichtian stages of the United Kingdom, with partirui $\sim$ r reference to southern England. Newsletters on Stratigraphy 12, 29-42.

Bailey, H.W., Gale, A.S., Mortimore, R.N., Swiecicki, A., U ooc, C.J., 1984. Biostratigraphical criteria for the recognition c! the coniacian to Maastrichtian stage boundaries in the Chalk of North West $i u_{1}$ ppe, with particular reference to southern England. Bulletin of the Geological s:

Balteș, N., 1967a. Microflora from Miocene sa'.-, earing formations of the PreCarpathian Depression (Rumania). Re $r i \mathrm{k}$, f Palaeobotany and Palynology 2 , 183-194.

Balteş, N., 1967b. The microflora of the : bian "Green Sands" in the Moesic Platform (Rumania). Review of Palaeoi ntany and Palynology 5, 183-197.

Bardet, N., Mazin, J.-M., Azéma, C., 'st o ${ }^{\prime}$ uen, V., Masure, E., 1991. L'Ichthyosaure de Bedeille (Ariege, France) evar ' 1 palynologique de la gangue et mise au point stratigraphique. Bulletin -'e la Société Géologique de France, 8e série 162, 897903.

Barreda, V.D., Palamarczu'r, S., 2000. Continental and marine palynomorphs from the type area of the $M^{M}{ }^{2}{ }^{2}$, seon Formation, Santa Cruz Province, Argentina. Ameghiniana $5^{7}-1$.

Barrois, C., 1876. Recher ches sur le terrain Crétacé Supérieur de l'Angleterre et de l'Irlande. Lille: Imprimerie et Librairie Six-Horemans, 232pp.

Barss, M.S., Bujak, J.P., Williams, G.L., 1979. A palynological zonation and correlation of sixty-seven wells. Geological Survey of Canada, Paper 78, 1-118.

Bath, A.H., Edmunds, W.M., 1981. Identification of connate water in interstitial solution of chalk sediment. Geochimica et Cosmochimica Acta 45, 1449-1461.

Batten, D.J., Morrison, L., 1983. Methods of palynological preparation for palaeoenvironmental, source potential and organic maturation studies. Norwegian Petroleum Directorate, Bulletin 2,35-53.

Bebout, J.W., 1981. An informal palynologic zonation for the Cretaceous System of the United States Mid-Atlantic, (Baltimore Canon Area), outer continental shelf. Palynology 5, 159-194. 
Bedwell, F.A., 1874. The Isle of Thanet. The ammonite zone, the depth of the Chalk in section, and the continuity of its flint floorings. Geological Magazine, New Series, Decade II 1, 16-22.

Bell, D.G., Selnes, H., 1997. The first appearance datum (FAD) of Heterosphaeridium difficile (Manum and Cookson) dinoflagellate, in clastic deposits, offshore Norway. Journal of Micropalaeontology 16, 30.

Below, R., 1981. Dinoflagellaten-zysten aus dem oberen Hauterive bis unteren Cenoman süd-West-Marokkos. Paläeontographica Abteilung B 176, 1-145.

Below, R., 1982. Scholochorate cysts of Gonyaulacaceae (Dinophyceae) from the Lower Cretaceous of Morocco. Paläeontographica Abteilung B 182, 1-51.

Below, R., 1984. Aptian to cenomanian dinoflagellate cysts from the mazagan plateau, Northwest Africa (sites 545 and 547, Deep Sea Drillin - ?roject leg 79). In: Hinz, K., Winterer, E.L., et al. (Eds), Initial Reports of the Deep coa ? rilling Project, U.S. Government Printing Office, 79, Washington, pp. 62:-64 9.

Bengtson, P., 1996. The Turonian stage and substage b iuni aries. In: Proceedings "Second International Symposium on Cretaceo: s Stage Boundaries" Brussels 8 16 September 1995. l'Institut Royal des Scier.ce. Naturelles de Belgique, pp. 6979.

Bettar, I., Meon, H., 2006. La palynoflore cont'، ،t . tale de l'Albien du bassin d'Agadir Essaouira (Maroc). Revue de Paléobio'os'o jenève 25, 593-631.

Blake, J.F., 1878. On the chalk of Yorks'_ire Pruceedings of the Geologists' Association 5, 232-270.

Bloch, J.D., Schroder-Adams, C.J., Lecı: ‘., D.A., Craig, J., McIntyre, D.J., 1999.

Sedimentology, micropaleor 0 ' ng, geochemistry, and hydrocarbon potential of shale from the Cretaceous ${ }^{\mathrm{I}}$ or ${ }^{\prime}:$ Colorado Group in Western Canada. Geological Survey of Canada, Bulleti: $531,1-185$.

Bower, C.R., Farmery, J.R., 191i Zones of the Lower Chalk of Lincolnshire. Proceedings of the Geologists' As 'ocic tion 21, 333-359.

Brenner, G.J., 1974. Pal no: tratigraphy of the Lower Cretaceous Gevar'am and Talme Yafe Formations $\eta$ uie Gevar'am 2 well (Southern Coastal Plin, Israel). Geological Survey of Israel, $B$, lletin 59, 1-27.

Brideaux, W.W., McIntyre, D.J., 1975. Miospores and microplankton from Aptian-Albian rocks along Horton River, District of MacKenzie. Geological Survey of Canada, Bulletin, 252 1-85.

Brideaux, W.W., Myhr, D.W., 1976. Lithostratigraphy and dinoflagellate cyst succession in the Gulf Mobil Parsons N-10 Well, District of MacKenzie. Geological Survey of Canada, Paper 76, 235-249.

Brinkhuis, H., Schiøler, P., 1996. Palynology of the Geulhemmerberg Cretaceous/Tertiary boundary section (Limburg, southeast Netherlands). Geologie en Mijnbouw 75, 193-213.

Bristow, C.R., 1990. Geology of the Country around Bury St Edmunds HMSO, London.

Bristow, C.R., Mortimore, R.N., Wood, C.J., 1997. Lithostratigraphy for mapping the Chalk of southern England. Proceedings of the Geologists' Association 108, 293-315. 
Bromley, R.G., Ekdale, A.A., 1987. Mass transport in European Cretaceous chalk; fabric criteria for its recognition. Sedimentology 34, 1079-1092.

Bromley, R.G., Gale, A.S., 1982. The lithostratigraphy of the English Chalk Rock. Cretaceous Research 3,273-306.

Brydone, R.M., 1912. The Stratigraphy of the Chalk of Hants London: Dulau and Co. Ltd, $116 \mathrm{pp}$.

Brydone, R.M., 1914. The zone of Offaster pilula in the south English Chalk. Geological Magazine 6, 359-369, 405-411, 449-457, 509-513.

Brydone, R.M., 1939. The Chalk zone of Offaster pilula London: Dulau and Company 8 pp.

Bubík, M., Skupien, P., Švábenická, L., 2008. Stratigrafie kř́ídových pestrých oceánských vrstev karpatského flyše na Moravě. Geologické výzku my na Moravě a ve Slezsku v roce 2007 , Brno 2008, 46-52.

Bujak, J.P., Williams, G.L., 1978. Cretaceous palynostratigr 'phy of offshore southeastern Canada. Geological Survey of Canada, Bulletin 297, $1 \cdot 1$.

Burnett, J.A., 1988. North-west European Late Cretac' 'ous calcareous Nannofossils: Biostratigraphy and Selected Evolutionary Li.a.gus. Unpublished PhD thesis. University College London.

Burnett, J.A., 1990. A new nannofossil zonatio _ sheme for the Boreal Campanian. International Nannofossil Association $\mathrm{N}$ w⿳ etter 12, 67-70.

Burger, D., 1982. Palynological examin ،ic n o: Late Mesozoic sediments in GSQ Hughenden 7, and notes on geolo ${ }_{5} ;$ al events in the northern Eromanga Basin. Queensland Government Mining Jour nal 83, 421-432.

Burger, D., 1988. Early Cretaceous e, vir onements in the Eromanga Basin; palynological evidence from GSQ Wyandra- r rrehole. In: Jell, P.A., Playford, G. (Eds),

Palynological and Palaeo ota ${ }^{l}$ ical Studies in Honour of Basil E. Balme. Association of Australasian Palaeor olo jists, Memoir 5, 173-186.

Busby, J.P., Smith, N.J.P., 2701. The nature of the Variscan basement in southeast England: evidence $\therefore \mathrm{n}_{\ldots}$ integrated potential field modelling. Geological Magazine $138,669-685$.

Calis, N., Drummond, D.J ., 2008. Hydrogeologic data from six test wells in the Upper Patapsco and Lower Patapsco aquifers in Southern Maryland. Maryland Geological Survey Basic Data Report 22, 1-74.

Cao, W.C., Zahirovic, S., Flament, N., Williams, S., Golonka, J., Muller, R.D., 2017. Improving global paleogeography since the late Paleozoic using paleobiology. Biogeosciences 14, 5425-5439.

Caron, M., Robaszynski, F., Amédro, F., Baudin, F., De Coninck, J., Hochuli, P., Salis-Perch Nielsen, K.V., Tribouillard, N-P., 1999. Duration of the oceanic anoxic event at the Cenomanian - Turonian boundary cyclostratigraphic interpretation of the Bahloul Formation in Central Tunisia. Bulletin de la Société Géologique de France, 8e série $170,145-160$.

Carter, D.J., Hart, MB., 1977. Aspects of mid-Cretaceous stratigraphic micropalaeontology. Bulletin of the British Museum of Natural History (Geology) $29,1-135$. 
Chadwick, R.A., Evans, D.J., 2005. A seismic atlas of southern England: images of subsurface structure Keyworth, Nottingham: British Geological Survey.

Chen, Y.Y., 1978. Jurassic and Cretaceous palynostratigraphy in the Morondava Basin of Madagaskar. PhD thesis, University of Arizona, Arizona, 264 pp.

Clark, G., Piggott, S., 1933. The age of the British flint mines. Antiquity, 7, 166-183.

Clarke, L.J., Jenkyns, H.C., 1999. New oxygen isotope evidence for long-term Cretaceous climatic change in the Southern Hemisphere. Geology 27, 699-702.

Clarke, R., 1935. The flint-knapping industry at Brandon. Antiquity 9, 38-56.

Clarke, R.F.A., Verdier, J.P., 1967. An investigation of microplankton assemblages from the chalk of the Isle of Wight, England. Verhandelingen der Koninklijke Nederlandse Akademie van Wetenschappen, Afdeelino Natuurkunde, Eerste Reeks 24, 1-96.

Clarke, R.F.A., Davey, R.J., Sarjeant, W.A.S, Verdier, J.P., 19 8. A note on the nomenclature of some Upper Cretaceous and Eocene dinoflagel ^u taxa. Taxon 17, 181-183.

Cobban, W.A., Walaszczyk, I., Obradovich, J.D., McKin` ey, …, 2006. A USGS Zonal Table for the Upper Cretaceous Middle Cenomaniar ${ }^{-1}$ "1austrichtian of the Western Interior of the United States Based on Ammo, ite; Inoceramids, and Radiometric Ages. Reston, Virginia: USGS Open File Renc rt 2৬J6-1250, 46 pp.

Cocozza, C.D., Clarke, C.M., 1992. Eocene mirr s) s= nkton from La Meseta Formation, northern Seymour Island. Antarcti- Sc, ’nce 4, 355-362.

Cookson, I.C., 1956. Additional micropı ${ }^{*}$ kton from Australian Late Mesozoic and Tertiary sediments. Australia: Journal of Marine and Freshwater Res earch 7, 183191.

Cookson, I.C., Eisenack, A., 1958. Mii rr plankton from the Australian and New Guinea Upper Mesozoic sedimen's. $F_{1}$ oceedings of the Royal Society of Victoria 74, 19-79.

Cookson, I.C., Eisenack, A., 19七?. Microplankton from Australian Cretaceous sediments. Micropaleontology 6. 1-:8.

Cookson, I.C., Eisenack, A., 962 . Additional microplankton from Australian Cretaceous sediments. Mics - ná. ontology 8, 485-507.

Cookson, I.C., Hughes, …F., 1964. Microplankton from the Cambridge Greensand (MidCretaceous). Palaeontology 7, 37-59.

Cookson, I.C., Eisenack, A., 1969. Some microplankton from two bores at Balcatta, Western Australia. Journal of the Royal Society of Western Australia 52, 3-8.

Cookson, I.C., Eisenack, A., 1971. Cretaceous microplankton from Eyre No.1 Bore core 20, Western Australia. Proceedings of the Royal Society of Victoria 84, 217-225.

Cookson, I.C., Eisenack, A., 1974. Microplankton from Australian Mesozoic and Tertiary sediments. Paläeontographica Abteilung B 148, 44-93.

Corradini, D., 1973. Non-calcareous microplankton from the Upper Cretaceous of the Northern Apennines. Bollettino della Societa Paleontologica Italiana 11, 119-197. 
Costa, L.I., 1985. The Ascodinium plexus in the latest Albian to earliest Cenomanian offshore Arctic Norway. In: Third International Conference on Modern and Fossil Dinoflagellates, Egham, August, 1985, Abstracts, unnumbered page.

Costa, L.I., Davey, R.J., 1992. Dinoflagellate cysts of the Cretaceous System. In: Powell, A.J. (Ed.), A Stratigraphic Index of Dinoflagellate Cysts. Chapman and Hall, London, pp. 99-131.

Courtinat, B., 1993. The significance of palynofacies fluctuations in the Greenhorn Formation (Cenomanian-Turonian) of the Western Interior Basin, USA. Marine Micropaleontology 21, 249-257.

Courtinat, B., Crumière, J.-P., Méon, H., Schaaf, A., 1991. Les associations de kystes de dinoflagellés du Cénomanien-Turonien de Vergons (Bassin Vocontien France). Geobios 24,649-666.

Crampton, J., Mumme, T., Raine, I., Roncaglia, L., Schiøler, P Stı `ng, P., Turner, G., Wilson, G., 2000. Revision of the Piripauan and Haur uri $n$ local stages and correlation of the Santonian-Maastrichtian (Late $-\mathrm{rt}^{2}$ aceous) in New Zealand. New Zealand Journal of Geology and Geophysic , 4? 509-333.

Crampton, J., Raine, I., Strong, P., Wilson, G., 2001. ' 1lu ?r ated biostratigraphy of the Raukumara Series (Cenomanian-Coniacian) a ${ }^{2}{ }^{\prime}$ angaotane Stream, Raukumara Peninsula, New Zealand. New Zealand Jo יrrıal of úeology and Geophysics 44, 365389.

Da Gama, R.O.B.P., Lutz, B., Desjardins, Г., Th. mpson, M., Prince, I.M., Espejo, I., 2014. Integrated paleoenvironmental a 'a' $y$ sis of the Niobrara Formation: CretaceousWestern Interior Seaway, northern Colorado. Palaeogeography, Palaeoclimatology, Palaeoecolos. 413, 66-80.

Dakyns, J.R., Fox-Strangeways, C., L\& 81). The geology of the country around Driffield. HMSO, London.

Dam, G., Nøhr-Hansen, H., Ch. 'stiansen, F.G., Bojesen-Koefoed, J.A., Laier, T., 1998. The oldest marine Cretaceo's sediments in West Greenland (Umiivik-1 Borehole) record of the Cenomari-n-Turonian Anoxic Event? Geology of Greenland Survey Bulletin 180, $128 \cdot 13$ :

Dam, G., Nøhr-Hansen, t . , Pedersen, K.R., Sønderholm, M., 2000. Sedimentary and structural evidence of a new Early Campanian rift phase in the Nuussuaq Basin, West Greenland. Cretaceous Research 21,127-154.

Davey, R.J., 1969. Non-calcareous microplankton from the Cenomanian of England, northern France and North America. Part 1. British Museum (Natural History) Geology, Bulletin 17, 103-180.

Davey, R.J., 1970. Non-calcareous microplankton from the Cenomanian of England, Northern France and North America. Part 2. British Museum (Natural History) Geology Bulletin 18, 333-397.

Davey, R.J., 1978. Marine Cretaceous palynology of Site 361, DSDP Leg 40, off Southwestern Africa. In: Bolli, H.M., Ryan, W.B.F., et al. (Eds), Initial Reports of the Deep Sea Drilling Project, U.S. Government Printing Office, 40, Washington, pp. 883-913. 
Davey, R.J., 1979. Marine Apto-Albian palynomorphs from Holes 400A and 402A, IPOD, Leg 48, Northern Bay of Biscay. In: Montadert, L., Roberts, D.G., et al. (Eds), Initial Reports of the Deep Sea Drilling Project, U.S. Government Printing Office, 48, Washington, pp. 547-577.

Davey, R.J., 1988. Palynological zonation of the Lower Cretaceous, Upper and Uppermost Middle Jurassic in the northwestern Papuan Basin of Papua, New Guinea. Geological Survey of Papua New Guinea Memoir 13, 1-77.

Davey, R.J., Williams, G.L., 1966a. IV. The genera Hystrichosphaera and Achomosphaera. In: Davey, R.J., Downie, C., Sarjeant, W.A.S., Williams, G.L., Studies on Mesozoic and Cainozoic dinoflagellate cysts. Bulletin of the British Museum (Natural History), Geology Supplement 3, London, pp. 28-52.

Davey, R.J., Williams, G.L., 1966b. V. The genus Hystrichosphxeridium and its allies. In: Davey, R.J., Downie, C., Sarjeant, W.A.S., Williams, G.L., 'u ' dies on Mesozoic and Cainozoic dinoflagellate cysts. Bulletin of the British Mu. eum (Natural History), Geology Supplement 3, London, pp. 53-106.

Davey, R.J., Verdier, J.P., 1973. An investigation of mic $o_{r}^{1-1 n} .1$ kton assemblages from latest Albian (Vraconian) sediments. Revista Frna ñola de Micropaleontología 5 , 173-212.

Davey, R.J., Verdier, J.P., 1976. A review of certain non-cabulate Hystrichosphaerid dinocysts. Review of Palaeobotany and ?.y lology 22, 307-335.

Davey, R.J., Downie, C., Sarjeant, W.A.S., v Mlla ms, G.L., 1966. Fossil dinoflagellate cysts attributed to Baltisphaeridium. I. · $\Gamma$ dvey, R.J., Downie, C., Sarjeant, W.A.S., Williams, G.L., Studies on Mesozoic a.d Cainozoic Dinoflagellate Cysts. Bulletin of the British Museum (Natural Hı ${ }^{+}$ory), Geology Supplement 3, London, pp. 157175.

de Verteuil, L., Norris, G., 1996. Pa. ${ }^{+}$I. Dinoflagellate cyst zonation and allostratigraphy of the Chesapeake Grou s. 1. : Miocene dinoflagellate stratigraphy and systematics of Maryland and Virgi ‘ia, Micropaleontology, Supplement 42, 1-82.

Deane, H., 1849. On the nrce ${ }^{r}$ ence of fossil Xanthidia and Polythalamia in Chalk. Transactions of tl e M croscopy Society, London 2, 77-79.

Decommer, H., 1982. Pa, mological and sedimentological study of Jurassic and Cretaceous sedinıents from five boreholes from northern France. Annales de la Société Géologique du Nord 101, 161-176.

Deflandre, G., 1936a. Les flagelles fossiles. Apercu biologique et paleontologiques. Role geologique. Actualités scientifiques et industrielles 335, 1-97.

Deflandre, G., 1936b. Microfossiles des silex Crétacés. Premier partie. Generalites. Flagelles. Annales de Paléontologie 25, 151-191.

Deflandre, G., 1937. Microfossiles des silex Crétacés. Deuxiéme partie. Flagellés incertae sedis Hystrichosphaeridés. Sarcodinés. Organismes divers. Annales de Paléontologie 26, 51-103.

Deflandre, G., Courteville, H., 1939. Note préliminaire sur les microfossiles des silex Crétacés du Cambréssis. Bulletin de la Société Française de Microscopie 8, 95-106. 
Deflandre, G., Cookson, I.C., 1955. Fossil microplankton from Australian Late Mesozoic and Tertiary sediments. Australian Journal of Marine and Freshwater Research 6 , 242-313.

Dettmann, M.E., Thomson, M.R.A., 1987. Cretaceous palynomorphs from the James Ross Island area, Antarctica. Bulletin of the British Antarctic Survey 77, 13-59.

Deville de Periere, M., Pellenard, P., Thibault, N., 2019. The Santonian - Campanian Boundary Event (SCBE) In Boreal basins: New geochemical and mineralogical data from the Northern Chalk Province (East Yorkshire, UK). Cretaceous Research 95, 61-76.

Diederix, D.O.J., de Haan, R., Tichler, W.O., 1972. Site 138. In: Hayes, D.E., Pimm, A.C., et al. (Eds), Initial Reports of the Deep Sea Drilling Project, U.S. Government Printing Office 14, Washington, p. 138.

Ditchfield, P., Marshall, J.D., 1989. Isotopic variation in rhyth mı ?lly bedded chalks: Paleotemperature variation in the Upper Cretaceous Ge logy 17, 842-845.

Dodsworth, P., 1996. Stratigraphy, microfossils and de osi ional environments of the lowermost part of the Welton Chalk Formation Late Cenomanian to early Turonian, Cretaceous) in eastern England. Pr uc ecuings of the Yorkshire Geological Society 51, 45-64.

Dodsworth, P., 2000. Trans-Atlantic dinoflagfilo.e cyst stratigraphy across the Cenomanian - Turonian (Cretaceous) Si, of boundary. Journal of Micropalaeontology 19, 69-84.

Dodsworth, P., 2004a. The distribution ` dinoflagellate cysts across a Late Cenomanian carbon isotope $\left(\delta^{13} \mathrm{C}\right)$ anomai, in the Pulawy borehole, central Poland. Journal of Micropalaeontology 23, 77-8?

Dodsworth, P., 2004b. Palynolowr o 't'.1e Cenomanian-Turonian (Cretaceous) boundary section at Aksudere, Crin. 'a. ralynology 28, 129-141.

Dodsworth, P., 2016. Palync stı .tigraphy and palaeoenvironments of the Eagle Ford Group (Upper Creta ${ }^{\circ}$ ou ) at the Lozier Canyon outcrop reference section, west Texas, USA. Palyn $\boldsymbol{л}_{\mathbf{c}}^{\mathrm{T}} \mathrm{y}$ 40, 357-378.

Dodsworth, P., Eldret,, ' \., 2019. A dinoflagellate cyst zonation of the Cenomanian and Turonian (Upper $r_{i}$ etaceous) in the Western Interior, United States. Palynology $43,701-723$.

Dolding, P.J.D., 1992. Palynology of the Marambio Group (Upper Cretaceous) of northern Humps Island. Antarctic Science 4, 311-326.

Duane, A.M., 1996. Palynology of Byers Group (Late Jurassic-Early Cretaceous) of Livingston and Snow Islands, Antarctic Peninsula: its biostratigraphical and palaeoenvironmental significance. Review of Palaeobotany and Palynology 91, 241-281.

Dueñas-Jimenez, H., 1990. Dinoflagellates, a new tool for the biostratigraphic control of sediments from the Middle and Upper Cretaceous. Revista de la Academia Colombiana de Ciências Exactas, Fisicas y Naturales 17, 433-440. 
Duxbury, S., 2001. A palynological zonation scheme for the Lower Cretaceous: United Kingdom Sector, Central North Sea. Neues Jahrbuch für Geologie und Paläontologie. Abhandlungen 219, 95-137.

Eisenack, A., Cookson, I.C., 1960. Microplankton from Australian Lower Cretaceous sediments. Proceedings of the Royal Society of Victoria 72, 1-11.

El-Beialy, S.Y., 1993. Mid-Cretaceous palynomorphs from the Bardawil-1 borehole, North Sinai, Egypt. Cretaceous Research 14, 49-58.

El-Beialy, S.Y., 1995. Campanian-Maestrichian palynomorphs from the Duwi (Phosphate) Formation of the Hamrawein and Umm El-Hueitat Mines, Red Sea Coast, Egypt. Review of Palaeobotany and Palynology 85, 303-317.

Eldrett. J,S., Ma, C., Bergman, S.C., Lutz, B., Gregory, F.J., Dodsworth, P., Phipps, M., Hardas, P., Minisini, D., Ozkan, A., Ramezani, J., Bowriı.? S.A., Kamo, S.L., Ferguson, K., Macaulay, C., Kelly, A.E., 2015. An astronomically c nlib, ?ted stratigraphy of the Cenomanian, Turonian and earliest Coniacian from $t$, e $C$ etaceous Western Interior Seaway, USA: Implications for global chr',nu tratigraphy. Cretaceous Research 56, 316-344.

Ernst, G., 1963. Stratigraphische und gesteinschem isc:e untersuchungen im Santon und Campan von Lägerdorf (SW-Holstein). Mitteiı ‘jen aus dem Geologischen Staatsinstitut im Hamburg 32, 72-127.

Ernst, G., Schmid, F., Siebertz, E., 1983. Ever: s' ra jigraphie im Cenoman und Turon von NW Deutschland. Zitteliana 10,5? 5 s 1 .

Eshet, Y., Moshkovitz, S., Habib, D., Ben) ، nini, C., Magaritz, M., 1992. Calcareous nannofossil and dinoflagellate stratigraphy across the Cretaceous/Tertiary boundary at Hor Hahar, Israe' Ma mine Micropaleontology 18, 199-228.

Eshet, Y., Hoek, R., Almogi-Labin A., 1',94. A new dinocyst-based biostratigraphic framework for Campaniā' '-Maastrichtian organic rich-carbonate sequences in Israel. Geological Surve, of Israel, Report 94, 1-24.

Fauconnier, D., 1979. Les tino 'agelles de l'Albien et du Cenomanien inferieur du Bassin de Paris. Docume' «s tu Bureau des Recherches Géologiques et Minières 5, 1-146.

Fauconnier, D., 1984. ' '7ı ine Cretaceous palynology of Holes 549 and 550, Deep Sea Drilling Project J er, 80, Northern Bay of Biscay. In: Graciansky, P.C. de, Poag, C.W., et al. (Eds), Initial Reports of the Deep Sea Drilling Project, U.S. Government Printing Office 80, Washington, pp. 653-662.

Fauconnier, D., Masure, E., 2004. Les dinoflagellés fossile. Guide pratique de détermination. Les genres à processus et à archéopyle apical. 602 p p., BRGM Editions.

Faÿ-Gomord, O., Allanic, C., Verbiest, M., Honlet, R., Champenois, F., Bonifacie, M., Chaduteau, C., Wouters, S., Muchez, P., Lasseur, E., Swennen, R., 2018. Understanding fluid flow during tectonic reactivation: an example from the Flamborough Head Chalk outcrop (UK). Geofluids 2018, doi.org/10.1155/2018/9352143.

Felix, C.J., Burbridge, P.P., 1976. Age of microplankton studied by Manum and Cookson from Graham and Ellef Ringes Islands. Geoscience and Man 15, 83-86. 
Fensome, R.A., Norris, G., 1982. Palynostratigraphic comparison of Cretaceous of the Moose River Basin, Ontario, with marginal marine assemblages from the Scotian Shelf and Alberta. Ontario Geological Survey, Miscellaneous Paper 103, 37-42.

Fensome, R.A., Taylor, F.J.R., Norris, G., Sarjeant, W.A.S., Wharton, D.I., Williams, G.L., 1993. A classification of living and fossil dinoflagellates. Micropaleontology, Special Publication Number 7,1-351.

Fensome, R.A., Crux, J.A., Gard, I.G., MacRae, R.A., Williams, G.L., Thomas, F.C., Fiorini, F., Wach, G., 2008. The last 100 million years on the Scotian Margin, offshore eastern Canada: an event-stratigraphic scheme emphasizing biostratigraphic data. Atlantic Geology 44, 93-126.Fensome, R.A., Williams, G.L., MacRae, R.A., 2009. Late Cretaceous and Cenozoic fossil dinoflagellates and other palynomorphs from the Scotian Margin, offshore eastern Canada. Journal of Systematic Palaeontology 7,1 79.

Fensome, R.A., Williams, G.L., Wood, S.E.L., Riding, J.B., 201 9. ^ review of the areoligeracean dinoflagellate cyst Cyclonephelium n $n_{4} \ldots$... orphologically similar genera. Palynology 43, supplement 1, 1-71.

Fiet, N., Masure, E., 2001. Albian dinoflagellates from $t_{t_{\star}}$. Umbria-Marche Basin (Italy); Proposed biozonation for the Tethys Domai: $\mathrm{Cr}$ taceous Research 22, 63-77.

FitzPatrick, M.E.J., 1995. Dinoflagellate cyst binctı atigraphy of the Turonian (Upper Cretaceous) of Southern England. Creta $f$ ou s Research 16, 757-791.

Fletcher, T.P., 1977. Lithostratigraphy $r_{\text {i }}$ ' in Northern Ireland. HMSO, Lonu $>r$.

Foad, M.T., Lashin, G.M.A., 2012. Ap. Southwestern Part of the Werter. Desert, Egypt. Journal of Applied Sciences Research 8, 1870-1877.

Foucher, J.-C., 1971a. Etude mi``opaleontologique des silex coniaciens du puits 19 de Lens-Lievin (Pas-de-Cais). Bulletin du Museum National d'Histoire Naturelle, Sciences de la Terre 5, ,7-129.

Foucher, J.-C., 1971b. Min tussiles des Silex Coniaciens de la falaise du Boise-de-Cise (Somme). Cahı rs te Micropaléontologie 8, 1-13.

Foucher, J.-C., 1974. Mic' ofossiles des silex du Turonien Superieur de Ruyalcourt (Pas de-Calais). Annales de Paléontologie 60,111-164.

Foucher, J.-C., 1975a. Dinoflagellés et acritarches des silex Crétacés du bassin de Paris: une synthèse stratigraphique. Annales Scientifiques de l'Université de Reims et de l'A.R.E.R.S. (Association régionale pour l'étude et la recherche scientifiques) 13, 810.

Foucher, J.-C., 1975b. Kystes de Dinoflagellés des Bassins de Mons et de Paris. In: Robaszynski, F. (Ed.), Les facies du Senonien (Maestrichtian-Mons-Lille). Livretguide des excursions dans le Crétacé du Limbourg, de la region de Mons et du Nord de la France. Groupe Français du Crétacé 13-16 Mai 1975, p. 21.

Foucher, J.-C., 1976a. Les Dinoflagellés des Silex et la Stratigraphie du Crétacé Supérieur Français. Revue de Micropaléontologie 18, 213-220. 
Foucher, J.-C., 1976b. Microplancton des silex Crétacés du Beauvaisis. Cahiers de Micropaléontologie, Nouvelle série 2, 3-28.

Foucher, J.-C., 1979. Distribution stratigraphique des kystes de Dinoflagellés et des acritarches dans le Crétacé Supérieur du Bassin de Paris et de l'Europe septentrionale. Paläeontographica Abteilung B 169, 78-105.

Foucher, J.-C., 1980. Dinoflagellés et Acritarches. In: Robaszynski, F., Amédro, F., Foucher, J.-C., Gaspard, D., Magniez-Jannin, F., Manivit, H., Sornay, J. (Eds), Synthèse biostratigraphique de l'Aptien au Santonien du Boulonnais a partir de sept groupes paléontologiques (foraminifères, nannoplancton, dinoflagellés et microfaunes. Revue de Micropaléontologie 22, 288-297.

Foucher, J.-C., 1981. Kystes de Dinoflagellés du Crétacé Moyen Européen: Proposition d'une eschelle biostratigraphique pour le domaine no d-occidental. Cretaceous Research 2, 331-338.

Foucher, J.-C., 1982. Dinoflagellés. Mémoires du Muséum I 'atic nal d'Histoire Naturelle. Nouvelle Serie, Serie C, Sciences de la Terre 49, 2'.8-?'28.

Foucher, J.-C., 1983. Distribution des Kystes de Dinof! ygenes dans le Crétacé moyen et Supérieur du Bassin de Paris. Cahiers de Mic op ’leontologie, Nouvelle série 4, 23 41.

Foucher, J.-C., Robaszynski, F., 1977. Micropla ، „n .n des silex du Bassin de Mons (Belgique) (Dinoflagellés Crétacés et $\Gamma a_{1}$. or.s). Annales de Paléontologie 63, 1958.

Foucher, J.-C., Pons, D., Mami, L., Bellier, ', -P., 1994. Premier Inventaire de la microflore Crétacé (Dinokystes, Spores $\epsilon$ : nollen) du Sud-Est Constantinois (Algeria): Consequences biostratigraph: ‘ut -. Comptes Rendus de l'Académie des Sciences, Série II 318, 1563-1570.

Fraser, T.H., Bon, J., Samuel, L., 99. A new dynamic stratigraphy for the West Irian micro-continent, Indor sia, and its implications. Proceedings of the 22nd Annual Convention of the Indo. asian Petroleum Association, pp. 707-761.

Gale, A.S., 1989. Field m =t: ing at Folkestone Warren, 29th November, 1987. Proceedings of the Geologis ' $i$ 's', ciation 100, 73-82.

Gale, A.S., 1995. Cyclortr atigraphy and correlation of the Cenomanian stage in Western Europe. In: House, M.R., Gale, A.S. (Eds), Orbital Forcing Timescales and Cyclostratigraphy. Geological Society of London Special Publication 85, 177-197.

Gale, A.S., 1996. Turonian correlation and sequence stratigraphy of the Chalk in southern England. In: Hesselbo, S.P., Parkinson, D.N. (Eds), Sequence Stratigraphy in British Geology. Geological Society of London Special Publication 103, 177-195.

Gale, A.S., Smith, A.B., 1982. The palaeobiology of the irregular echinoids Infulaster and Hagenowia. Palaeontology 25, 11-42.

Gale, A.S., Friedrich, S., 1989. Appendix. Occurrence of the ammonite genus Sharpeiceras in the Lower Cenomanian Chalk Marl of Folkestone. Field Meeting at Folkestone Warren, 29th November, 1987. Proceedings of the Geologists' Association 100, 80-82. 
Gale, A.S., Jenkyns, H.,C., Kennedy, W.J., Corfield, R.M., 1993. Chemostratigraphy versus biostratigraphy: data from around the Cenomanian - Turonian boundary. Journal of the Geological Society London 150, 29-32.

Gale, A.S., Montgomery, P., Kennedy, W.J., Hancock, J.M., Burnett, J.A., McArthur, J.M., 1995. Definition and global correlation of the Santonian-Campanian boundary. Terra Nova 7, 611-622.

Gale, A.S., Hancock, J.M., Bristow, R., Mortimore, R.N., Wood, C.J., 1999. 'Lithostratigraphy for mapping the Chalk of southern England' by Bristow et al. (1997): Discussion. Proceedings of the Geologists' Association 110, 65-72.

Gale, A.S., Kennedy, W.J., Voigt, S., Walaszczyk, I., 2005. Stratigraphy of the Upper Cenomanian-Lower Turonian Chalk succession at Eastbourne, Sussex, UK: ammonites, inoceramid bivalves and stable carbon isr topes. Cretaceous Research 26, 460-487.

Gale, A.S., Kennedy, W.J., Lees, J.A., Petrizzo, M.R., Walszczy k, I. 2007. An integrated study (inoceramid bivalves, ammonites, calcareo' 'S I 7 nnofossils, planktonic foraminifera, stable carbon isotopes) of the Ten $\mathrm{N}_{*}{ }^{\cdot} \cdot$ iseek section, Lancaster, Dallas County, north Texas, a candidate Globa' ho 'ndary Stratotype Section and Point for the base of the Santonian Stage. Ac: ' Ge Jlogica Polonica 57, 113-160.

Gale, A.S., Hancock, J.M., Kennedy, W.J., Petrizzn M.R., Lees, J.A., Walaszczyk, I., Wray, D.S., 2008. An integrated study (geoche $n$ 'st $y$, stable oxygen and carbon isotopes, nannofossils, planktonic foraminiferá, inoceramid bivalves, ammonites and crinoids) of the Waxahachie Dar. Sp llway section, north Texas: a possible boundary stratotype for the base 0 . the Campanian Stage. Cretaceous Research 29, 131-167.

Gallois, R.W., 1988. Geology of the Cr, $r$ try around Ely. HMSO, London.

Gallois, R.W., 1994. Geology of t ne ?ountry around King's Lynn and The Wash London: HMSO, London.

Gallois, R.W., 2016. The stratiraphy of the Middle Chalk (Upper Cretaceous) succession at Mundford, Norfnlk, 'W. Proceedings of the Geologists' Association 127, 451463.

Gallois, R.W., Morter, A.t ., 1976. Trunch Borehole, Mundesley (132) Sheet. In: IGS Boreholes 1975. London: Institute of Geological Sciences, pp. 8-10.

Gambacorta, G., Malinverno, A., Erba, E., 2019. Orbital forcing of carbonate versus siliceous productivity in the late Albian-late Cenomanian (Umbria-Marche Basin, central Italy). Newsletters on Stratigraphy 52, 197-220.

Garg, R., Khowaja-Ateequzzaman, Jain, K.P., 1988. Jurassic and Lower Cretaceous dinoflagellate cysts from India with some remarks on the concepts of Upper Gondwana. In: Venkatachala, B.S., Maheshwari, H.K. (Eds), Concepts, limits and extension of the Indian Gondwana. The Palaeobotanist 36, 254-267.

Gaunt, G.D., Fletcher, T.P., Wood, C.J., 1992. Geology of the Country around Kingston upon Hull and Brigg. HMSO, London.

Gedl, P., 2007. Dinocysts from Upper Cretaceous deep-water marine variegated facies (Malinowa Shale Formation), Pieniny Klippen Belt, Poland: example from the Potok Trawne creek. Studia Geologica Polonica 127, 139-152. 
Gee, J.S., Kent, D.V., 2007. Source of oceanic magnetic anomalies and the geomagnetic polarity timescale. In: Schubert, G. (Ed.), Treatise on Geophysics, 5. Geomagnetism. Elsevier. Amsterdam, pp. 455-507.

Gitmez, G.U., Ertug, K., 1999. Dinoflagellate cysts and acritarchs from the JurassicCretaceous boundary, Northwest Anatolia, Turkey. Micropaleontology 45, 69-98.

Gocht, H., 1959. Microplankton from the northwest Germany Neocomian (Part II). Paläeontologische Zeitschrift 33, 50-89.

Gradstein, F.M., Williams, G.L., 1976. Biostratigraphy of the Labrador Shelf. Part 1. Geological Survey of Canada, Open File Report 349, 1-32.

Gradstein, F.M, Ogg, J., Smith, A.G., 2004. A geologic time scale 2004. Cambridge University Press, Cambridge, 589 pp.

Gradstein, F.M., Ogg, J.G., Schmitz, M.D., Ogg, G.M., 2012. The _oologic Time Scale 2012. Elsevier, Amsterdam, 1144 pp.

Grant, S.F., Coe, A.L., Armstrong, H.A., 1999. Sequence st s $^{-i g r a p h y ~ o f ~ t h e ~ C o n i a c i a n ~}$ succession of the Anglo - Paris Basin. Geologica' L' ag „zine 136,17-38.

Green, J.P., 2019. The macrofauna of the Vale Hous _ _lin's Member (Burnham Chalk Formation, Upper Turonian, Late Cretaceous, of Lincolnshire and a palaeoenvironmental reconstruction. Proce edings of the Yorkshire Geological Society 62, 195-200.

Habib, D., 1977. Comparison of Lower a kiddle Cretaceous palynostratigraphic zonations in the Western North. tla . Itic. In: Swain, F.M. (Ed.), Stratigraphic Micropaleontology of Atlantic Basin ? nd Borderlands. Elsevier Scientific Publication, Amsterdam, pp. 34_-367.

Habib, D., Drugg, W.S., 1987. Palyr. o' o $y$ y of Sites 603 and 605. In: van Hinte, J.E., Wise, S.W. Jr, et al. (Eds), Initial $\kappa t_{1}$ o , ts of the Deep Sea Drilling Project, U.S. Government Printing Of Sic, 93, Washington, pp. 751-775.

Habib, D., Miller, J.A., 1989. L: noilagellate species and organic facies evidence of marine transgression and $\mathrm{re}_{5}$ 'e', sion in the Atlantic Coastal Plain. Palaeogeogr aphy, Palaeoclimatolog.', Pá'aeoecology 74, 23-47.

Haga, H., 1990. Palynolc ;y report of outcrop samples from North Slope, Alaska. Alaska Division of Geolu $\_$ical and Geophysical Surveys. Public-data File 90, 1-20.

Hammer, Ø., Harper, D.A.T., Ryan, P.D., 2001. PAST: Paleontological Statistics software package for education and data analysis. Palaeontologica Electronica 4, 9.

Hampton, M.J., Bailey, H.W., Gallagher, L.T., Mortimore, R.N., Wood, C.J., 2007. The biostratigraphy of Seaford Head, Sussex, southern England; an international reference section for the basal boundaries for the Santonian and Campanian Stages in chalk facies. Cretaceous Research 28, 46-60.

Hancock, J.M., 1975. The petrology of the Chalk. Proceedings of the Geologists' Association 86, 499-535.

Hancock, J.M., Gale, A.S., 1996. The Campanian Stage. In: Proceedings "Second International Symposium on Cretaceous Stage Boundaries" Brussels 8 - 16 September 1995. l'Institut Royal des Sciences Naturelles de Belgique, pp. 103-109. 
Hansen, J.M., 1977. Dinoflagellate stratigraphy and echinoid distribution in Upper Maastrichtian and Danian deposits from Denmark. Geological Society of Denmark, Bulletin (Meddelelser Fra Dansk Geologisk Forening) 26, 1-26.

Hansen, J.M., 1979a. Dinoflagellate zonation around the boundary. In: Christensen, W.K., Birkelund, T. (Eds), The Maestrichtian and Danian of Denmark. Cretaceous Tertiary Boundary Events Symposium 18 - 24 September 1979. University of Copenhagen, pp. 136-141.

Hansen, J.M., 1979b. A new dinoflagellate zone at the Maastrichtian/Danian Boundary in Denmark. Danmarks Geologiske Undersøgelse 1978, 131-140.

Haq, B.U., Hardenbol, J., Vail, P.R., 1987. Chronology of fluctuating sea levels since the Triassic. Science 235, 1156-1167.

Harker, S.D., Sarjeant, W.A.S., 1975. The stratigraphic distril "tion of organic-walled dinoflagellate cysts in the Cretaceous and Tertiary. Rerie r. of Palaeobotany and Palynology 20, 217-315.

Harker, S.D., Sarjeant, W.A.S., Caldwell, W.G.E., 1990. Lé łe C etaceous (Campanian) organic-walled microplankton from the interio: vlaıns of Canada, Wyoming and Texas; biostratigraphy, palaeotology and pal ^e ${ }^{2}$ r vironmental interpretation. Paläeontographica Abteilung B 219, 1-243.

Harris, P.T., O'Brien, P.E., Quilty, P., McMinn, f., ' inldway, D., Exon, N.F., Hill, P.J., Wilson, C.W., 1999. Sedimentation and Contin n llope processes in the vicinity of an ocean waste-disposal site, southe .s ?r. Tasmania. Australian Journal of Earth Sciences 46, 577-591.

Hart, M.B., 2019. The 'Black Band': is cal expression of a global event. Proceedings of the Yorkshire Geological Society [?, ¿17-226.

Hart, M.B., Dodsworth, P., Ditchfiold, F.W., Duane, A.M., Orth, C.J., 1991. The Late Cenomanian event in eas ? arn Ingland. Historical Biology 5, 339-354.

Hasegawa, T., Crampton, J., Scri: $x$ ler, P., Field, B., Fukushi, K., Kakizaki, Y., 2013. Carbon isotope stratigraphy ana depositional oxia through Cenomanian/Turonian boundary sequen _es (upper Cretaceous) in New Zealand. Cretaceous Research 40, 61-80.

Heine, C.J., 1991. Late Sa atonian to Early Maastrichtian dinoflagellate cysts of northeast Texas. In: Thompson, L.B., Heine, C.J., Percival, S.F., Selznick, M.R., (Eds), Stratigraphy and micropalaeontology of the Campanian shelf in northeast Texas. Micropalaeontology, Special Publication 5, New York, pp. 117-147.

Helby, R.J., Morgan, R., Partridge, A.D., 1987. A palynological zonation of the Australian Mesozoic. In: Jell, P.A., (Ed.), Studies in Australian Mesozoic Palynology. Memoir of the Association of Australiasian Palaeontologists, Memoir 4, 1-94.

Helby, R.J., Wilson, G.J., Grant-Mackie, J.A., 1988. A preliminary biostratigraphic study of Middle to Late Jurassic dinoflagellate assemblages from Kawhia, New Zealand. In: Jell, P.A., Playford, G. (Eds), Palynological and Palaeobotanical Studies in Honour of Basil E. Balme. Association of Australasian Palaeontologists, Memoir 5, pp. 125 166. 
Helden, B.G.T.V., 1977. Correlation of microplankton assemblages with ammonite faunas from the Jurassic Wilkie Point Formation, Prince Patrick Island, District of Franklin. Geological Survey of Canada, Paper 77, 163-171.

Helenes, J., 1984. Morphological analysis of Mesozoic-Cenozoic Cribroperidinium (Dinophyceae), and taxonomic implications. Palynology 8, 107-137.

Helenes, J., De Guerra, C., Vasquez, J., 1998. Palynology and chronostratigraphy of the Upper Cretaceous in the subsurface of the Barinas Area, Western Venezuela. AAPG, Bulletin 82, 1308-1328.

Herbin, J.P., Masure, E., Roucache, J., 1987. Cretaceous formations from the lower continental rise off Cape Hatteras: Organic geochemistry, dinoflagellate cysts and the Cenomanian-Turonian boundary event at Sites 603, (Leg 93), and 105, (Leg 11). In: Hinte, J.E. van, Wise, S.W. Jr, et al. (Eds), Initial Reports of the Deep Sea Drilling Project, U.S. Government Printing Office 93, Wd. hington, pp. 1139-1162.

Herngreen, G.F.W., 1978. A preliminary dinoflagellate zon. tior of Aptian-Cenomanian in the Netherlands. Palinologiá, Número extraord na. io 1, 273-281.

Herngreen, G.F.W., Randrianasolo, A., Verbeek, J.W., 1 78น. Micropaleontology of Albian to Danian strata in Madagascar. Micropaleor on gy 28, 97-109.

Herngreen, G.F.W., Eillebrecht, A.T.J.M., Gortemakrr, .' E., Remmelts, G., Schuurman, H.A.H.M., Verbeek, J.W., 1996. Upper Crf id _eous Chalk Group stratigraphy near the Isle of Texel, The Netherlands (a multi $\lambda_{1}$, ir inary approach). Mededelingen Rijks Geologische Dienst, Nieuwe Serie « 153.

Hewitt, H.D., 1924. Notes on some Chaln ections in the district around Thetford, Norfolk Proceedings of the Ge logists' Association 35, 220-244.

Hewitt, H.D., 1935. Further notes ', n :he Chalk of the Thetford District, Norfolk Proceedings of the Geologicts' $\Delta$, sociation 46, 18-37.

Hildreth, P.N., 2013. The Vale Hu'se Flints Member, a flint-rich unit of the Burnham Chalk Formation of th? N rrthern Province, East Yorkshire and Lincolnshire, UK. Proceedings of the Yorks iire Geological Society 59, 177-186.

Hildreth, P.N., 2019. Th 2 di: tribution and form of flint, with particular reference to the Chalk Group ( $\mathrm{U}_{1}$ ' $\mathrm{e}_{\mathrm{I}}$ cretaceous) of the Northern Province, UK. Proceedings of the Yorkshire Geolorir al Society 62, 178-186.

Hill, W., 1888. On the lower beds of the Upper Cretaceous Series in Lincolnshire and Yorkshire. Quarterly Journal of the Geological Society of London 44, 320-364.

Hill, W., Jukes-Browne, A.J., 1886. The Melbourn Rock and zone of Belemnitella plana from Cambridge to the Chiltern Hills. Quarterly Journal of the Geological Society of London 42, 216-231.

Hochuli, P., Kelts, K., 1979. Palynology of Middle Cretaceous black clay facies from Deep Sea Drilling Project sites 417 and 418 of the western North Atlantic. In: Donnelly, T., Francheteau, J., Bryan, W., Robinson, P., Flower, M., Salisbury, M., et al. (Eds), Initial Reports of the Deep Sea Drilling Project, U.S. Government Printing Office, 51-53, Washington pp. 897-935.

Hoek, R.P., Eshet, Y., Almogi-Labin, A., 1996. Dinoflagellate cyst zonation of Campanian Maestrichtian sequences in Israel. Micropaleontology 42, 125-150. 
Hollister, C.D., Ewing, J.I., Habib, D., Hathaway, J.C., Lancelot, Y., Luterbacher, H., Paulus, F.J., Poag, C.W., Wilcoxon, J.A., Worstell, P., 1972. Site 101: Blake-Bahama Outer Ridge (Southern End). Initial reports of the Deep Sea Drilling Project, 14, Washington, pp. 105-110.

Hopson, P.M., 1992. Geology of the Letchworth, north-west Hitchin and Holwell district, Hertfordshire Keyworth. British Geological Survey. Technical Report WA/92/42.

Hopson, P.M., 2005. A stratigraphical framework for the Upper Cretaceous Chalk of England and Scotland with statements on the Chalk of Northern Ireland and the UK Offshore Sector. BG Survey. Research Report RR/05/01, 90 pp.

Howarth, R.J., McArthur, J.M., 1997. Statistics for strontium isotope stratigraphy: A robust LOWESS fit to the marine Sr-isotope curve for 0 to $206 \mathrm{Ma}$, with look-up table for derivation of numeric age. Journal of Geolog.' 105, 441-456.

Hultberg, S.U., 1985. Dinoflagellate studies of the Upper Manctı: htian and Danian in southern Scandinavia. PhD thesis, University of Stoc hol n, Stockholm, $189 \mathrm{pp}$.

Husson, D., Galbrun, B., Laskar, J., Hinnov, L.A., Thibault N., Gardin, S., Locklair, R.E., 2011. Astronomical calibration of the Maastric': 'tan (Late Cretaceous). Earth and Planetary Science Letters 305, 328-340.

Ilyina, V.I., Kulkova, I.A., Lebedeva, N.K., 1994. Mic*op nytofossils and detail stratigraphy of marine Mesozoic and Cenozoic of Sib, $\mathrm{r}_{1}$, Obedinennyi Institut Geologii Geoliziki i Mineralogii, (Novosibirsk) \&1: $1-192$.

Ioannides, N.S., 1986. Dinoflagellate cy ,ts ron Upper Cretaceous-Lower Tertiary sections, Bylot and Devon Islands, . rctic Archipelago. Geological Survey of Canada, Bulletin 371, 1-99.

Islam, M.A., 1993. Review of the fo ss : dinioflagellate Cleistosphaeridium. Revista Española de Micropaleontrlogín 25, 81-94.

Jain, K.P., 1977. Additional dir or? gellates and acritarchs from Grey Shale Member of Dalmiapuram Formatinn, South India. The Palaeobotanist 24, 170-194.

Jain, K.P., Taugourdeau-La. ${ }^{+}$z J., 1973. Palynology of Dalmiapuram grey shale, Dalmiapuram For mai on, District Trichinopoly, south India: Taxonomy. Geophytology 3, : $<-08$.

Jain, K.P., Millepied, P., i 975. Cretaceous microplankton from Senegal Basin, West Africa. Part 2. Systematics and biostratigraphy. Geophytology 5, 126-171.

Japsen, P., 1997. Regional Neogene exhumation of Britain and the western North Sea. Journal of the Geological Society of London 154, 239-247.

Jaramillo, C., Amezquita, O.Y., 1994. Palinoestratigrafía del Grupo Olini (ConiacianoCampaniano), Valle Superior del Magdalena, Colombia. Estudios Geológicos del Valle Superior del Magdalena 17,1-18.

Jarvis, I., 2003. Sample preparation for ICP-MS. In: Jarvis, K.E., Gray, A.L., Houk, R.S. (Eds), Handbook of Inductively Coupled Plasma Mass Spectrometry. Viridian, Woking 172-224.

Jarvis, I., Woodroof, P.B., 1984. Stratigraphy of the Cenomanian and basal Turonian (Upper Cretaceous) between Branscombe and Seaton, SE Devon, England. Proceedings of the Geologists' Association 95, 193-215. 
Jarvis, I., Leary, P.N., Tocher, B.A., 1987. Mid-Cretaceous (Albian - Turonian) stratigraphy of Shapwick Grange Quarry, S.E. Devon, England. Mesozoic Research 1, 119-134.

Jarvis, I., Carson, G.A., Cooper, M.K.E., Hart, M.B., Leary, P.N., Tocher, B.A., Horne, D., Rosenfeld, A., 1988a. Microfossil assemblages and the Cenomanian - Turonian (late Cretaceous) oceanic anoxic event. Cretaceous Research 9, 3-103.

Jarvis, I., Carson, G.A., Hart, M.B., Leary, P.N., Tocher, B.A., 1988b. The Cenomanian Turonian (late Cretaceous) anoxic event in SW England: evidence from Hooken Cliffs near Beer, SE Devon. Newsletters on Stratigraphy 18, 147-164.

Jarvis, I., Murphy, A.M., Gale, A.S., 2001. Geochemistry of pelagic and hemipelagic carbonates: criteria for identifying systems tracts and sea-level change. Journal of the Geological Society London 158, 685-696.

Jarvis, I., Mabrouk, A., Moody, R.T.J., De Cabrera, S.C., 2002. I tt Sretaceous (Campanian) carbon isotope events, sea-level change and correlat on , f the Tethyan and Boreal realms. Palaeogeography, Palaeoclimatology, Pal eo cology 188, 215-248.

Jarvis, I., Gale, A.S., Jenkyns, H.C., Pearce, M.A., 2006. 5 'cuır variation in Late Cretaceous carbon isotopes and sea-level change: evider ce 'rum a new $\mathrm{d}^{13} \mathrm{C}$ carbonate reference curve for the Cenomanian - Campa ${ }^{-12.1}$ (99.6 - 70.6 Ma). Geological Magazine 143, 561-608.

Jarvis, I., Lignum, J.S., Gröcke, D.R., Jenkyns, 'H.` T earce, M.A., 2011. Black shale deposition, atmospheric $\mathrm{CO}_{2}$ drav $u^{\prime} W_{*}$ and cooling during the Cenomanian Turonian Oceanic Anoxic Event. '? - oceanography 26, 17 pp.

Jarvis, I., Trabucho-Alexandre, J., Gi s̈cke, D.R., Uličný, D., Laurin, J., 2015. Intercontinental correlation $r f$ or $c$ anic carbon and carbonate stable isotope records: evidence of climate a' $d$ sea-level change during the Turonian (Cretaceous). The Deposit 101 ? Record 1, 53-90.

Jeans, C.V., 1973. The Market Veighton Structure: tectonics, sedimentation and diagenesis during the L. ataceous. Proceedings of the Yorkshire Geological Society $39,409-444$.

Jeans, C.V., 1980. Eaı 'v s ' h narine lithification in the Red Chalk and Lower Chalk of east England: a bacterl l control model and its implications. Proceedings of the Yorkshire Geological Society 43, 81-157.

Jeans, C.V., Long, D., Hall, M.A., Bland, D.J., Cornford, C., 1991. The geochemistry of the Plenus Marls at Dover, England: evidence of fluctuating oceanographic conditions and of glacial control during the development of the Cenomanian - Turonian $\delta^{13} \mathrm{C}$ anomaly. Geological Magazine 128, 603-632.

Jefferies, R.P.S., 1963. The stratigraphy of the Actinocamax plenus subzone (Turonian) in the Anglo-Paris Basin. Proceedings of the Geologists' Association 74, 1-34.

Jenkyns, H.C., Gale, A.S., Corfield, R.M., 1994. Carbon- and oxygen-isotope stratigraphy of the English Chalk and Italian Scaglia and its palaeoclimatic significance. Geological Magazine 131, 1-34.

Jiabo, 1978. On the Paleogene dinoflagellates and acritarchs from the Coastal Region of Bohai. Nanjing Institute of Geology and Palaontology, Academia Sinica, Nanjing, China, 190 pp. 
Johnson, H., Lott, G.K., 1993. Cretaceous of the central and northern North Sea. Lithostratigraphic nomenclature of the UK North Sea. British Geological Survey, Keyworth pp. 94-115.

Jones, M.M., Sageman, B., Meyers, S.R., 2018. Turonian sea level and paleoclimatic events in astronomically tuned records from the tropical North Atlantic and Western Interior Seaway. Paleoceanography and Paleoclimatology 33, 470-492.

Joo, Y.J., Sageman, B.B., 2014. Cenomanian to Campanian carbon isotope chemostratigraphy from the Western Interior Basin, U.S.A. Journal of Sedimentary Research 84, 529-542.

Jukes-Browne, A.J., 1880. The subdivisions of the Chalk. Geological Magazine 7, 248257.

Jukes-Browne, A.J., Hill, W., 1903. The Cretaceous rocks of E ritain. Vol. II — The Lower and Middle Chalk of England London: His Majesty's Strtio.ery Office.

Jukes-Browne, A.J., Hill, W., 1904. The Cretaceous rocks of Iri'ain. Vol. III — The Upper Chalk of England London: His Majesty's Stationer ${ }^{r}$ Of ice.

Kaplan, U., Kennedy, W.J., 1996. Upper Turonian and L.niacian ammonite stratigraphy of Westphalia, NW Germany. Acta Geologice Polc nica 46, 305-352.

Kapoor, P.N., Prasad, B., Swamy, S.N., Shukla, M.. 1999. Palynostratigraphy and hydrocarbon source potential of Creata :e ı s sediments in Krishna Sub-Basin, India. Geoscience Journal 20,11-24.

Kauffman, E.G., Kennedy, W.J., Wood, ( I., - 996. The Coniacian stage and substage boundaries. In: Proceedings "Seconi. International Symposium on Cretaceous Stage Boundaries" Brussels 8 - 16 September 1995. l'Institut Royal des Sciences Naturelles de Belgique, pp. 81-?4.

Keating, J.M., 1992. Palynology $\boldsymbol{s}$ : he Lachman Crags Member, Santa Marta Formation (Upper Cretaceous) of $\mathrm{r}$ or :hwest James Ross Island. Antarctic Science 4, 293-304.

Keating, J.M., Spencer-Jones, M., Newham, S., 1992. The stratigraphical palynology of the Kotick Point and Whı kv Bay Formation, Gustav Group (Cretaceous), James Ross Island. Antarctic ? ciel ce 4,279-292.

Kjellström, G., 1973. Ma`strichtian microplankton from the Höllviken Borehole No.1 in Scania, southern ưweden. Sveriges Geologiska Undersökning, Serie C no. 688, 67, $1-59$.

Keller, G., Han, Q., Adatte, T., Burns, S.J., 2001. Palaeoenvironment of the Cenomanian Turonian transition at Eastbourne, England. Cretaceous Research 22, 391-422.

Kennedy, W.J., 1967. Burrows and surface traces from the Lower Chalk of southern England. Bulletin of the British Museum (Natural History) Geology 15, 127-167.

Kennedy, W.J., Garrison, R.E., 1975. Morphology and genesis of nodular chalks and hardgrounds in the Upper Cretaceous of southern England. Sedimentology 22, 311-386.

Kennedy, W.J., Gale, A.S., 2006. The Cenomanian Stage. Proceedings of the Geologists' Association 117, 187-205. 
Kennedy, W.J., Gale, A.S., Bown, P.R., Caron, M., Davey, R.J., Gröcke, D.R., Wray, D.S., 2000. Integrated stratigraphy across the Aptian-Albian boundary in the Marnes Bleues, at the Col de Pré-Guittard, Arnayon (Drôme), and at Tartonne (Alpes-de-HauteProvence), France: A candidate global boundary stratotype section and Boundary Point for the base of the Albian Stage. Cretaceous Research 21,591-720.

Kennedy, W.J., Walaszczyk, I., Cobban, W.A., 2005. The Global Boundary Stratotype Section and Point for the base of the Turonian Stage of the Cretaceous: Pueblo, Colorado, U.S.A. Episodes 28, 93-104.

Kerr, J.W., 1974. Geology of Bathurst Island Group and Byam Martin Island, Arctic Canada. Geological Survey of Canada, Memoir 378, 1-152.

Khomentovskii, O.V., Zakharov, V.A., Lebedeva, N.K., Vorobeva, O.I., 1999. Granitsa Santona i Kampana na Severe Sibiri. Geologiya i Geofirika 40, 512-529.

Khowaja-Ateequzzaman, Jain, K.P., 1992. Hauterivian-Barrnmı $n$ dinoflagellate cyst assemblage from subsurface of Polar Basin, Souther. In ia. Geophytology 22, 133-180.

Kimyai, A., 1992. Palynological assemblages of the Cr taceous sediments in the Fish Creek test Well No.1, North Slope, Alaska. Re'/sı' Lspañola de Micropaleontología $24,27-42$

Kimyai, A., 2000. Palynology and biostratigra' $n$, of the Lower Cretaceous sediments in the South Barrow Test well no. 1, Poin ¿ ' a r ow, Alaska. Palynology 24, 201-215.

Kirsch, K.-H., 1991. Dinoflagellate cystr of he upper Cretaceous of the Helvetic and Ultrahelvetic of the Upper Bavaria. Munchener Geowissenschaftliche Abhandlungen Reihe A, Geolo cie und Palaeontologie 22, 1-306.

Kjellström, G., 1973. Maastrichtiar n :rruplankton from the Höllviken Borehole no.1 in Scania, southern Sweden. Cres ig es Geologiska Undersöking, Afhandlingar och Uppsatser 67, 1-59.

Koppelhus, E.B., Pedersen, C.K., 1993. A palynological and sedimentological study of Cretaceous floodpla: $\eta$ de posits of the Atane Formation at Skansen and Igdlunguaq, Disko, West Greer.ia. d. cretaceous Research 14, 707-734.

Köthe, A., Khan, A.M., $\therefore$ × nı df, M., 1988. Biostratigraphy of the Surghar Range, Salt Range, Sulaiman Range ar d the Kohat area, Pakistan, according to Jurassic through Paleogene calcareous nannofossils and Paleogene dinoflagellates. Geologisches Jahrbuch Reihe B 71, 3-87.

Kurita, H., Obuse, A., 1994. Paleogene dinoflagellate cysts and pollen from the Haboro Formation, northern Central Hokkaido, Japan and their chronostratigraphic and paleoenvironmental implication. Journal of the Geological Society of Japan (Chishitsugaku Zasshi) 100, 292-301

Lamolda, M.A., Hancock, J.M., 1996. The Santonian Stage and substages. In: Proceedings "Second International Symposioum on Cretaceous Stage Boundaries" Brussels 8 16 September 1995. l'Institut Royal des Sciences Naturelles de Belgique, pp. 95 102.

Lamolda, M.A., Mao, S., 1999. The Cenomanian - Turonian boundary event and dinocyst record at Ganuza (Northern Spain). Palaeogeography, Palaeoclimatology, Palaeoecology 150, 65-82. 
Lamolda, M.A., Paul, C.R.C., 2007. Carbon and oxygen stable isotopes across the Coniacian/Santonian boundary at Olazagutia, northern Spain. Cretaceous Research 28,37-45.

Lamolda, M.A., Gorostidi, A., Paul, C.R.C., 1994. Quantitative estimates of calcareous nannofossil changes across the Plenus Marls (latest Cenomanian), Dover, England - implications for the generation of the Cenomanian - Turonian boundary event. Cretaceous Research 15, 143-164.

Lamolda, M.A., Paul, C.R.C., Peryt, D., Pons, J.M., 2014. The Global Boundary Stratotype and Section Point (GSSP) for the base of the Santonian Stage, "Cantera de Margas", Olazagutia, northern Spain. Episodes 37, 2-13.

Laurin, J., Čech, S., Uličný, D., Štaffen, Z., Svobodová, M., 2014. Astrochronology of the Late Turonian: Implications for the behavior of the carbon cycle at the demise of peak greenhouse, Earth and Planetary Science Letters s? 4, 254-269.

Lawal, 0., 1982. Palynological biostratigraphy and palaeo nvi onment of Cretaceous formations of Upper Benue, North-East Nigeria, Unlv rsity of Nice, Nice, 199 pp.

Leary, P.N., Peryt, D., 1991. The late Cenomanian oce: nic anoxic event in the western Anglo-Paris Basin and southeast Danish-Poli ,n .ruugh: survival strategies of and recolonisation by benthonic foraminifera. His ^ ${ }^{n}$ cal Biology 5, 321-338.

Lebedeva, N.K., 2006. Dinocyst biostratigraph y I the Upper Cretaceous of northern Siberia. Paleontological Journal 40, S6) 4 - S $5,21$.

Lebedeva, N.K., 2008. ДИНОЦИСТЫ И ذИ )С'ı РАТИГРАФИЯ ВЕРХНЕМЕЛОВЫХ ОТЛОЖЕНИЙ СЕВЕРА СИБИРИ,, , офимука Сибирского отделения Российской Академии наук, 11 pp.

Lebedeva, N.K., 2010. Palynofacies II 'Inper Cretaceous sediments of Northern Siberia. Stratigrafiya. Geologichesk ${ }^{\prime} V_{a ́} \mathrm{~K}$ Jrrelyatsiya 18, 70-87.

Leckie, D.A., Singh, C., Bloch, I D., Wilson, M., Wall, J., 1992. An anoxic event at the Albian-Cenomanian kาu. Jary; The Fish Scale Marker Bed, northern Alberta, Canada. Palaeogeog: $\mathrm{pph}_{\mathrm{y}}$, Palaeoclimatology, Palaeoecology 92, 139-166.

Lécuyer, C., 2016. Sean ater residence times of some elements of geochemical interest and the salinity i f tıe oceans. Bulletin de la Société Géologique de France 187, 245-259.

Lentin, J.K., Williams, G.L., 1973. Fossil dinoflagellates: index to genera and species. Geological Survey of Canada, Paper 73, 1-176.

Lentin, J.K., Williams, G.L., 1985. Fossil dinoflagellates: index to genera and species. Canadian Technical Report of Hydrography and Ocean Sciences 60, 1-451.

Lentin, J.K., Vozzhennikova, T.F., 1990. Fossil dinoflagellates from the Jurassic, Cretaceous and Paleogene deposits of the USSR - a restudy. American Association of Stratigraphic Palynologists, Contributions Series 23, 1-221.

Li, H., Habib, D., 1996. Dinoflagellate stratigraphy and its response to sea level change in Cenomanian - Turonian sections of the Western Interior of the United States. Palaios 11, 15-30.

Li, W., Liu, Z.-S., 1994. The Cretaceous palynofloras and their bearing on stratigraphic correlation in China. Cretaceous Research 15, 333-365. 
Lignum, J.S., 2008. Cenomanian (Upper Cretaceous) Palynology and Chemostratigraphy: Dinoflagellate Cysts as Indicators of Palaeoenvironmental and Sea-level Change. Unpublished PhD thesis, Kingston University, London, 579 pp.

Lignum, J.S., Jarvis, I., Pearce, M.A., 2008. A critical assessment of standard processing methods for the preparation of palynological samples. Review of Palaeobotany and Palynology 149, 133-149.

Linnert, C., Robinson, S.A., Lees, J.A., Perez-Rodriguez, I., Jenkyns, H.C., Petrizzo, M.R., Arz, J.A., Bown, P.R., Falzoni, F., 2018. Did Late Cretaceous cooling trigger the Campanian - Maastrichtian Boundary Event? Newsletters on Stratigraphy 51, 145-166.

Louwye, S., 1992. Dinoflagellate cyst stratigraphy of the Upper Cretaceous of Western Belgium. Bulletin de la Société Belge de Géologie, de Paléontologie et d'Hydrologie $101,255-275$.

Louwye, S., 1995. New dinoflagellate cyst species from Up, 'er ' 'retaceous subsurface deposits of western Belgium. Annales de la Sociét \& Gí ologique de Belgique 118, 147-159.

Ma, C., Meyers, S.R., Sageman, B.B., Singer, B.S., Jich d, L K., 2014. Testing the astronomical time scale for oceanic anoxic ev $n^{n+2}$, and its extension into Cenomanian strata of the Western Interinr Lasin (USA). Geological Society of America Bulletin 126, 974-989.

Macphail, M.K., Truswell, E.M., 2004. Pa'y on oy of Neogene slope and rise deposits from ODP Sites 1165 and 1167, ' ' ' S $^{+}$Antarctica. In: Cooper, A.K., O’Brien, P.E., Richter, C. (Eds), Proceedings of the ?cean Drilling Program, Scientific Results 188, College Station, Texas, pp. 1-20.

Mallon, A.J., Swarbrick, R.E., 2002. A cc inpaction trend for non-reservoir North Sea Chalk. Marine and Petrol€ un. (reology, 19, 527-539.

Mantell, G.A., 1845. Notes of a microscopical examination of the Chalk and Flint of southeast England, wit, remarks on the animalculites of certain Tertiary and modern deposits. An $\mathrm{I}_{\mathrm{K}} \mathrm{l}$ and Magazine of Natural History 16, 73-88.

Mantell, G.A., 1850. i. P $\mathrm{P}_{\mathrm{h}^{+}} \mathrm{n}$ ial Atlas of Fossil Remains Consisting of Coloured Illustrations Selecı ?d from Parkinson's "Organic Remains of a Former World", and Artis's "Antediluvıan Phytology" xii+207 pp.; Henry G. Bohn, London, U.K.

Manum, S.B., Cookson, I.C., 1964. Cretaceous microplankton in a sample from Graham Island, Arctic Canada, collected during the Second Fram Expedition (1898-1902). With notes on microplankton from the Hassel Fromation, Elef Ringnes Island. Norske Videdskaps-Akademi, 1. Matematisk-Naturvidenskapelig Klasse, Skrifter, Ny Serie, 17, 1-36.

Mao, S., Mohr, B.A.R., 1992. Late Cretaceous dinoflagellate cysts (?Santonian Maestrichtian) from the Southern Indian Ocean (Hole 748C). In: Wise, S.W. Jr, Schlich, R., et al. (Eds), Proceedings of the Ocean Drilling Program, Scientific Results 120, College Station, pp. 307-341.

Mao, S., Lamolda, M.A., 1998. Late Cenomanian and Early Turonian dinoflagellate cysts at Ganuza Navarr I. Systematic palaeontology. Revista Española de Paleontología 13, 261-286. 
Marheinecke, U., 1986. Dinoflagellaten des Maastrichtium der Grube Hemmoor (Niedersachsen). Geologisches Jahrbuch, Reihe A 93, 3-93.

Marshall, K.L., 1983. Dinoflagellate cysts from the Cenomanian, Turonian and Coniacian of Germany and England. Unpublished PhD thesis, University of Aberdeen, Aberdeen, $211 \mathrm{pp}$.

Marshall, K.L., Batten, D.J., 1988. Dinoflagellate cyst associations in CenomanianTuronian "Black Shale" sequences of northern Europe. Review of Palaeobotany and Palynology 54, 85-103.

Marshall, N.G., 1990. Campanian dinoflagellates from southeastern Australia. Alcheringa $14,1-38$.

Masure, E., 1983. Dinoflagellés. In: Neumann, M., Platel, J.P. (coord.), Le Campanien stratotypique: étude lithologique and micropaléontolirique.). Géologie Mediterranéenne 10,51-52.

Masure, E., 1984. L'indice de diversité et les dominances $d_{t}$ - "-ommunautés" de kystes de dinoflagellés: marqueurs bathymétriques; for; ge : $98 \mathrm{D}$, croisière $47 \mathrm{~B}$. Palaeobathymetry data; Drill Site 398D, Leg 47:'. Buıletin de la Société Géologique de France, 7e série 26, 93-111.

Masure, E., 1988. Albian-Cenomanian dinoflagella te ¿'sts from Sites 627 and 635, Leg 101, Bahamas. In: Austin, J.A., Jr, Schlagf $i, N$., et al. (Eds), Proceedings of the Ocean Drilling Program, Scientific Results 101, ' n'ege Station, pp. 121-138.

Masure, E., Vrielynck, B., 2009. Late Al , lar dinuflagellate cyst paleobiogeography as indicator of asymmetric sea surfac temperature gradient on both hemispheres with southern high latitudes v. .rmer than northern ones. Marine Micropaleontology 70,120-1?3.

Masure, E., Rauscher, R., Dejax, I Sc `.ler, M., Ferré, B., 1998. Cretaceous - Paleocene palynology from the Cote f'Ivuire - Ghana transform margin, Sites 959, 960, 961 and 962. In: Mascle, J., L 'hmann, G.P., Moullade, M. (Eds), Proceedings of the Ocean Drilling Program, Scien : fic Results 159, College Station, pp. 253-276.

Matthews, K.J., Maloney, n. T., Lahirovic, S., Williams, S.E., Seton, M., Müller, R.D., 2016. Global plate bu ' $\mathrm{n}_{\mathrm{\prime}}^{\prime} \mathrm{ar}$; evolution and kinematics since the late Paleozoic: Global and Planetary Cha ge 146, 226-250.

May, F.E., Stein, J.A., 1979. Dinoflagellate and acritarch assemblages from the Grandstand Formation, (Middle to Upper Albian), of the Nanushuk Group, Simpon Core Test 25, National Petroleum Reserve in Alaska, northern Alaska. Alaska. Division of Geological Survey. Information Circular. Preliminary results, study of Nanushuk Group Rocks 794, 128-145.

McArthur, J.M., 1994. Recent trends in strontium isotope stratigraphy. Terra Nova 6, 331-358.

McArthur, J.M., Kennedy, W.J., Gale, A.S., Thirlwall, M.F., Chen, M., Burnett, J., Hancock, J.M., 1992. Strontium isotope stratigraphy in the Late Cretaceous intercontinental correlation of the Campanian - Maastrichtian boundary. Terra Nova 4, 385-393.

McArthur, J.M., Thirlwall, M.F., Chen, M., Gale, A.S., Kennedy, W.J., 1993a. Strontium isotope stratigraphy in the Late Cretaceous: numerical calibration of the Sr isotope 
curve and intercontinental correlation for the Campanian. Paleoceanography 8 , 859-873.

McArthur, J.M., Thirlwall, M.F., Gale, A.S., Kennedy, W.J., Burnett, J.A., Mattey, D., Lord, A.R., 1993b. Strontium isotope stratigraphy for the Late Cretaceous: a new curve, based on the English Chalk. In: Hailwood, E.A., Kidd, R.B., (Eds), High Resolution Stratigraphy. Geological Society of London Special Publication 70, 195-209.

McArthur, J.M., Kennedy, W.J., Chen, M., Thirlwall, M.F., Gale, A.S., 1994. Strontium isotope stratigraphy for Late Cretaceous time - direct numerical calibration of the Sr isotope curve based on the United States Western Interior. Palaeogeography, Palaeoclimatology, Palaeoecology 108, 95-119.

McArthur, J.M., Howarth, R.J., Bailey, T.R., 2001. Strontium isotope stratigraphy: LOWESS version 3: Best fit to the marine Sr-isotope c':rve for 0 - $509 \mathrm{Ma}$ and accompanying look- up table for deriving numerical agt. Iournal of Geology 109, 155-170.

McArthur, J.M., Howarth, R.J., Shields, G.A., 2012. Stront un. isotope stratigraphy. In: Gradstein, F., Ogg, J.G., Schmitz, M., Ogg, G. (Eds) T: o jeologic Time Scale 2012. Amsterdam, Elsevier, pp. 127-144.

McArthur, J.M., Steuber, T., Page, K.N., Landman, N.1' - 016. Sr-Isotope stratigraphy: assigning time in the Campanian, Pliensbrrlian, ioarcian, and Valanginian. Journal of Geology 124, 569-586.

McIntyre, D.J., 1974. Palynology of an U r Pretaceous section, Horton River, District of MacKenzie, N. W. T. Geological S ¿ rv $\_$y of Canada, Paper 74, 1-57.

McMinn, A., 1988. Outline of a Late ?retaceous dinoflagellate zonation of Northwestern Australia. Alcheringa 12, 137 15i

McPherson, M.L., Currie, B.S., Piprsc n J.S., 2006. Reservoir Characterization of the Cretaceous Cedar Mount: in and Dakota Formations, Southern Uinta Basin: YearOne Report. Utah Geolc ${ }_{c}$ ical Survey, Open-File Report 492, 1-99.

Mearon, S., Paytan, A., Bránowı - T. T., 2003. Cretaceous strontium isotope stratigraphy using marine bari'.c. Feulogy 31, 15-18.

Mehrotra, N.C., Venka``Cııla, B.S., Swamy, S.N., Kapoor, P.N., 2002. Krishna - Godavari Basin. In: Palynclo sy in Hydrocarbon Exploration (The Indian Scenario). Memoir of the Geological Society of India 48,61-88.

Mertens, K.N., Verhoeven, K., Verleye, T., Louwye, S., Amori, A., Ribeiro, S., Deaf, A.S., Harding, I.C., Schepper, S. de, González, C., Kodrans-Nsiah, M., Vernal, A. de, Henry, M., Radi, T., Dybkjær, K., Poulsen, N.E., Feist-Burkhardt, S., Chitolie, J., HeilmannClausen, C., Londeix, L., Turon, J.-L., Marret, F., Matthiessen, J., McCarthy, F.M.G., Prasad, V., Pospelova, V., Kyffin Hughes, J.E., Riding, J.B., Rochon, A., Sangiorgi, F., Welters, N., Sinclair, N., Thun, C., Soliman, A., Nieuwenhove, N. van, Vink, A., Young, M., 2009. Determining the absolute abundance of dinoflagellate cysts in recent marine sediments: The Lycopodium marker-grain method put to the test. Review of Palaeobotany and Palynology 157, 238-252.

Meyers, S.R., Siewert, S.E., Singer, B.S., Sageman, B.B., Condon, D.J., Obradovich, J.D., Jicha, B.R., Sawyer, D.A., 2012. Intercalibration of radioisotopic and astrochronologic 
time scales for the Cenomanian - Turonian boundary interval, Western Interior Basin, USA. Geology, pp. 407-10.

Mildenhall, D.C., 1977. Cretaceous palynomorphs from the Waihere Bay Group and Kahuitara Tuff, Chatham Islands, New Zealand. New Zealand Journal of Geology and Geophysics 20,655-672.

Mildenhall, D.C., Wilson, G.J., 1976. Cretaceous palynomorphs from the Sisters Islets, Chatham Islands, New Zealand. New Zealand Journal of Geology and Geophysics $19,121-126$.

Millioud, M.E., 1969. Dinoflagellates and acritarchs from some western European Lower Cretaceous type localities, in Proceedings of the 1st International Conference on Planktonic Microfossils, Geneva 1967, edited, pp. 420-434, Leiden.

Mitchell, J., 1836. On the chalk and flint of Yorkshire, as con., nared with the chalk and flint of the southern counties of England. The Edinburrh 1 'ow Philosophical Journal, Exhibiting a View of the Progressive Discov ries and Improvements in the Sciences and the Arts 20,68-74.

Mitchell, S.F., 1994. New data on the biostratigraphy $f$ the Flamborough Chalk Formation (Santonian, Upper Cretaceous) be cw en South Landing and Danes Dyke, North Yorkshire. Proceedings of the Yo. ${ }^{-1}{ }_{r}$-nire Geological Society 50,113118.

Mitchell, S.F., 1995a. Lithostratigraphy and 'jic str atigraphy of the Hunstanton Formation (Red Chalk, Cretaceourj, uc assion at Speeton, North Yorkshire, England. Proceedings of the Yor - $^{-}$; e Geological Society 50, 285-303.

Mitchell, S.F., 1995b. Uintacrinus ar ricus Kasmussen from the Upper Cretaceous Flamborough chalk formation nt :'rrkshire: Implications for the position of the Santonian - Campanian bou ir'al y. Cretaceous Research 16, 745-756.

Mitchell, S.F., 2000. The Welto: For nation (Chalk Group) at Speeton, NE England: implications for the latt Cretaceous evolution of the Market Weighton Structure. Proceedings of the Yor ${ }^{-h}$ 're Geological Society 53, 17-24.

Mitchell, S.F., 2005. Eigf $\_$i alemnite biohorizons in the Cenomanian of northwest Europe and the ${ }{ }_{1}, n n$,rtance. Geological Journal 40, 363-382.

Mitchell, S.F., 2019. The :halk Group (Upper Cretaceous) of the Northern Province, eastern England - a review. Proceedings of the Yorkshire Geological Society 62, 153-177.

Mitchell, S.F., Veltkamp, C.J., 1997. Schackoina moliniensis Reichel from the Lower Cenomanian of north-east England and its stratigraphical significance. Proceedings of the Yorkshire Geological Society 51, 367-372.

Mitchell, S.F., Paul, C.R.C., Gale, A.S., 1996. Carbon isotopes and sequence stratigraphy. In: Howell, J.A., Aitken, J.F. (Eds), High Resolution Sequence Stratigraphy: Innovations and Applications. The Geological Society of London Special Publication 104, 11-24.

Mohamed, O., Piller, W.E., Egger, H., 2012. The dinocyst record across the Cretaceous/Palaeogene boundary of a bathyal mid-latitude Tethyan setting: Gosau Group, Gams Basin, Austria. Cretaceous Research 35, 143-168. 
Mohr, B.A.R., 1990. Early Cretaceous palynomorphs from ODP Sites 692 and 693, the Weddell Sea, Antarctica. In: Barker, P.F., Kennett, J.P., et al. (Eds), Proceedings of the Ocean Drilling Program, Scientific Results 113, College Station, pp. 449-464.

Mohr, B.A.R., Gee, C.T., 1992. Late Cretaceous palynofloras, (sporomorphs and dinocysts) from the Kerguelen Plateau, Southern India Ocean (Sites 748 and 750). In: Wise, S.W. Jr, Schlich, R., et al. (Eds), Proceedings of the Ocean Drilling Program, Scientific Results 120, College Station, pp. 281-306.

Mohr, B.A.R., Wähnert, V., Lazarus, D.B., 2002. Mid-Cretaceous paleobotany and palynology of the Central Kerguelen Plateau, Southern Indian Ocean (ODP Leg 183, Site 1138). In: Frey, F.A., Coffin, M.F., Wallace, P.J., Quilty, P.G. (Eds), Proceedings of the Ocean Drilling Program, Initial Reports 183, College Station, Texas, 1-39 pp.

Moradian, F., Allameh, M., 2010. Palynology of the Abderaz 'ormation in Hamam Ghaleh in Kopet Dagh sedimentary basin, in The 1st Internatic $\left.\mathbf{1}^{\prime}\right\urcorner$ l Applied Geological Congress, edited, pp. 920-924, Department of Geolo ;y, , lamic Azad University Mashad Branch, Iran, 26-28 April 2010.

Morgan, R., 1978. Albian to Senonian palynology of Si e ?a s, Angola Basin. In: Bolli, H.M., Ryan, W.B.F., et al. (Eds), Initial Reports of the $n_{\epsilon} \eta$ Sea Drilling Project, U.S. Government Printing Office 40, Washington, . $p$.' 15-951.

Morgan, R., 1980. Palynostratigraphy of the Auctı alian early and middle Cretaceous. Geological Survey of New South Wales, 'ria ontology Memoir 18,1-153.

Morgenroth, P., 1966. Lower Eocene mi ${ }_{-1}$ fo - sils and concretions of Northwest Germany. Paläeontographica Ab، ‘il ^ng B 119, 1-53.

Morter, A.A., Gallois, R.W., Clark, R.i 1975. Record of the IGS Trunch borehole. London: IoG Sciences.

http://scans.bgs.ac.uk/sobi jr ar s/boreholes/517419/images/12114521.html.

Mortimer, R., 1878. On the flin' ' of the Chalk of Yorkshire. Proceedings of the Geologists' Association 5, 344-354.

Mortimore, R.N., 1983. Th॰ str *tigraphy and sedimentation of the Turonian Campanian in the su truern Province of England. Zitteliana 10,27-41.

Mortimore, R.N., 198t. Su dtigraphy of the Upper Cretaceous White Chalk of Sussex. Proceedings of the Geologists' Association 97, 97-139.

Mortimore, R.N., 2014a. Logging the Chalk. Dunbeath, Caithness. Whittles Publishing 53 pp.

Mortimore, R.N., 2014b. A stratigraphic framework for the Chalk: Transitional Province (London Basin, Chiltern Hills and East Anglia). In: Logging the Chalk. Dunbeath, Caithness: Whittles Publishing, pp. 117-173.

Mortimore, R.N., Wood, C.J., 1986. The distribution of flint in the English Chalk with particular reference to the "Brandon Flint Series" and the high Turonian flint maximum. In: The Scientific Study of Flint and Chert. Cambridge University Press, pp. 7-20.

Mortimore, R.N., James, L., 2015. The search for onshore analogues for the offshore Upper Cretaceous Chalk of the North Sea. Proceedings of the Geologists' Association 126, 188-210. 
Mortimore, R.N., Wood, C.J., Gallois, R.W., 2001. British Upper Cretaceous Stratigraphy Peterborough: Joint Nature Conservation Committee, 558 pp.

Müller, R.D., Cannon, J., Qin, X., Watson, R.J., Gurnis, M., Williams, S., Pfaffelmoser, T., Seton, M., Russell, S.H.J., Zahirovic, S., 2018. GPlates — Building a Virtual Earth Through Deep Time: Geochemistry, Geophysics, Geosystems 15, 30 pp.

Newell, A.J., Woods, M.A., Farrant, A.R., Smith, H., Haslam, R.B., 2018. Chalk thickness trends and the role of tectonic processes in the Upper Cretaceous of southern England. Proceedings of the Geologists' Association 129, 610-628.

Nicolas, M.P.B., 2008. Williston Basin Project (Targeted Geoscience Initiative II): Results of the biostratigraphic sampling program, southwestern Manitoba (NTS 62F, 62G4, 62K3). Manitoba Geological Survey, Geoscientific Paper GP2880-1, 1-28.

Nikitenko, B.L., Pestchevitskaya, E.B., Lebedeva, N.K., Ilyina, V.I., 2008.

Micropalaeontological and palynological analyses acrnss he Jurassic-Cretaceous boundary on Nordvik Peninsula, Northeast Siberia. I ew: letters on Stratigraphy $42,181-222$.

Nøhr-Hansen, H., 1991. Dinoflagellate cyst zonation c "Barremian to Albian deposits from East Greenland. Palynology 15, 248-24 3.

Nøhr-Hansen, H., 1993. Dinoflagellate cyst stratigrap'v of the Barremian to Albian, Lower Cretaceous, Northeast Greenlanr'. ‘ . ¿ønlands Geologiske Undersøgelse, Bulletin 166, 1-171.

Nøhr-Hansen, H., 1994. Dinoflagellate ys1 biostratigraphy of the Upper Cretaceous Black Mudstones on Svartenhuk h. 'vø, West Greenland. Grønlands Geologiske Undersøgelse, Open File Seriє: 94, 1-25.

Nøhr-Hansen, H., 1996. Upper Cre ar ous dinoflagellate cyst stratigraphy, onshore West Greenland. Grønlands Geo lngi l 12 Unders øgelse, Bulletin 170,1-103.

Nøhr-Hansen, H., 2012. Palyn ss ‘ atigraphy of the Cretaceous-lower Palaeogene sedimentary successic $n$. the Kangerlussuaq Basin, southern East Greenland. Review of Palaeobo'?ny and Palynology 178, 59-90.

Nøhr-Hansen, H., McIn1 vre, D.J., 1998. Upper Barremian to Upper Albian (Lower Cretaceous) din flayellate cyst assemblages, Canadian Arctic Archipelago. Palynology 22, 14:-166.

Nøhr-Hansen, H., Williams, G.L., Fensome, R.A., 2016. Biostratigraphic correlation of the western and eastern margins of the Labrador-Baffin Seaway and implications for the regional geology. Geological Survey of Denmark and Greenland, Bulletin 37, 77 pp.

Nøhr-Hansen, H., Costa, L.I., Pearce, M.A., Alsen, P., 2018. New Albian to Cenomanian (Cretaceous) dinoflagellate cyst taxa of ovoidinioid affinities from East Greenland, the Barents Sea and England. Palynology 42,366-391.

Norvick, M.S., Burger, D., 1976. Palynology of the Cenomanian of Bathurst Island, Northern Territory, Australia. Bureau of Mineral Resources, Geology and Geophysics, Bulletin 151, 1-169.

Núñez-Betelu, L.K., MacRae, R.A., Hills, L.V., Muecke, G.K., 1992. Uppermost AlbianCampanian palynological biostratigraphy of Axel Heiberg and Ellesmere Islands 
(Canadian Arctic). United States Department of Interior, OCS Report, MMS. Stratigraphy and Paleogeography. 1992 Proceedings International Conference on Arctic Margins 94(40), 135-140.

Núñez-Betelu, L.K., Hills, L.V., Krause, F.F., McIntyre, D.J., 1994. Upper Cretaceous paleoshorelines of the northeastern Sverdrup Basin, Ellesmere Island, Canadian Arctic Archipelago. Stratigraphy, Biostratigraphic Correlation and Paleogeography. 1994 Proceedings International Conference on Arctic Margins, pp. 43-49.

O'Brien, C.L., Robinson, S.A., Pancost, R.D., Damste, J.S.S., Schouten, S., Lunt, D.J., Alsenz, H., Bomemann, A., Bottini, C., Brassell, S.C., Farnsworth, A., Forster, A., Huber, B.T., Inglis, G.N., Jenkyns, H.C., Linnert, C., Littler, K., Markwick, P., McAnena, A., Mutterlose, J., Naafs, B.D.A., Puttmann, W., Sluijs, A., van Helmond, N.A.G.M., Vellekoop, J., Wagner, T., Wrobel, N.E., 2017. Cretaceous sea-surface temperature evolution: Constraints from TEX86 and planktonic for * niniferal oxygen isotopes. Earth-Science Reviews 172, 224-247.

Ogg, G., 1994. Dinoflagellate cysts of the Early Cretaceom N.: ih Atlantic Ocean. Marine Micropaleontology 23, 241-263.

Ogg, J.G., Hinnov, L.A., 2012. Cretaceous. In: Gradstein. I M., Ogg, J.G., Schmitz, M.D., Ogg, G.M. (Eds), The Geological Time Scale 2012. 'Iser ier, Amsterdam, pp. 793-853.

Ogg, J.G., Agterberg, F.P., Gradstein, F.M., 2004 The Crecaceous Period. In: Gradstein, F.M., Ogg, J.G., Smith, A.G. (Eds), A Geolo ri za Time Scale 2004. Cambridge: Cambridge University Press, pp. 344-'83.

Ogg, J.G., Ogg, G., Gradstein, F., 2016. A 'o'ccise geologic time scale Amsterdam: Elsevier, $240 \mathrm{pp}$.

Ohkouchi, N., Kawamura, K., Kajiwə^a, ' ’ , Wada, E., Okada, M., Kanamatsu, T., Taira, A., 1999. Sulfur isotope records a: o und Livello Bonarelli (northern Apennines, Italy) black shale at the Cenomé nla? - Turonian boundary. Geology 27, 535-538.

Olde, K., Jarvis, I., Pearce, M., ' Tičný, D., Tocher, B., Trabucho-Alexandre, J., Gröcke, D., 2015. A revised northe $n$ suropean Turonian (Upper Cretaceous) dinoflagellate cyst biostratigraphv: $n^{\text {t }}$ grating palynology and carbon isotope events. Review of Palaeobotany anc Pal nology 213,1-16.

Olde, K., Jarvis, I., Pearct M.A., Walaszczyk, I., Tocher, B.A., 2016. Organic-walled dinoflagellate cys records from a prospective Turonian - Coniacian (Upper Cretaceous) GSSP, Słupia Nadbrzeżna, Poland. Cretaceous Research 65, 17-24.

Olivero, B., Palamarczuk, S., 1987. Cenomanian ammonites and dinoflagellates from James Ross Island, Antarctica. Ameghiniana 24, 35-49.

Oltz, D.F., 1969. Numerical analyses of palynological data from Cretaceous and Early Tertiary sediments in East Central Montana. Palä eontographica Abteilung B 128, 90-166.

Owen, H.G., 1992. The Gault - Lower Greensand Junction Beds in the northern Weald (England) and Wissant (France), and their depositional environment. Proceedings of the Geologists' Association 103, 83-110.

Owen, H.G., 1995. The upper part of the Carstone and the Hunstanton Red Chalk (Albian) of the Hunstanton Cliff, Norfolk. Proceedings of the Geologists' Association 106, 171-181. 
Owens, J.D., Gill, B.C., Jenkyns, H.C., Bates, S.M., Severmann, S., Kuypers, M.M.M., Woodfine, R.G., Lyons, T.W., 2013. Sulfur isotopes track the global extent and dynamics of euxinia during Cretaceous Oceanic Anoxic Event 2. Proceedings of the National Academy of Sciences USA 110, 18407-18412.

Palamarczuk, S., Ambrosini, G., Villar, H., Medina, F., Martinez-Macchiavello, J.C., Rinaldi, C., 1984. The Lopez de Bertodano and Sobral Formations of Vicecomodora Marambio Island, Antarctica. Congreso Geológico Argentino, Actas del Noveno 1, 399-419.

Palynodata Inc, White, J.M., 2008. Palynodata datafile: 2006 version. Geological Survey of Canada.

Paul, C.R.C., Lamolda, M.A., 2009. Testing the precision of bioevents. Geological Magazine 146, 625-637.

Paul, C.R.C., Mitchell, S.F., Marshall, J.D., Leary, P.N., Gale, A.c L : ane, A.M., Ditchfield, P.W., 1994. Palaeoceanographic events in the Middle Cer omanian of Northwest Europe. Cretaceous Research 15, 707-738.

Paul, C.R.C., Lamolda, M.A., Mitchell, S.F., Vaziri, M.R., 'orustidi, A., Marshall, J.D., 1999. The Cenomanian - Turonian boundary at Ea cou urne (Sussex, UK): a proposed European reference section. Palaeogeograph; ralaeoclimatology, Palaeoecology 150, 83-121.

Pavlishina, P., 1990. Early Cenomanian paly x $n r$ sphs near the village of Sanadinovo, central north Bulgaria. Review of 'it bu lgarian Geological Society 51, 89-101.

Peake, N.B., Hancock, J.M., 1961. The Up $p_{r}$ ar Cretaceous of Norfolk. Transactions of the Norfolk and Norwich Naturalı'ts' Society 19, 293-339.

Peake, N.B., Hancock, J.M., 1970. T'ı 'Inper Cretaceous of Norfolk. In: The Geology of Norfolk. Geological Society of . Jr rfolk. Norwich, pp. 293-339.

Peake, N.B., Hancock, J.M., 20^u. The Chalk of Norfolk I 1961 - 2000. In: The Geological Society of Norfolk 50th A. niversary Jubilee Volume. Geological Society of Norfolk. Norwich, pp. 22-26.

Pearce, M.A., 2000. Paly nol gy and Chemostratigraphy of the Cenomanian to Lower Campanian Chai c vi southern and Eastern England. Unpublished PhD thesis, Kingston Universit $y$ London, 432 pp.

Pearce, M.A., 2010. New genera and species of organic-walled dinoflagellate cysts from the Cenomanian to lower Campanian of the Trunch borehole, southeast England. Journal of Micropalaeontology 29, 51-72.

Pearce, M.A., 2018. Additional new organic-walled dinoflagellate cysts from two onshore UK Chalk boreholes. Journal of Micropalaeontology 37, 73-86.

Pearce, M.A., Williams, G.L., 2018. Fetchamium prolixispinosum gen. et comb. nov. (division Dinoflagellata). Journal of Micropalaeontology 37, 17-20.

Pearce, M.A., Jarvis, I., Swan, A.R.H., Murphy, A.M., Tocher, B.A., Edmunds, W.M., 2003. Integrating palynological and geochemical data in a new approach to palaeoecological studies: Upper Cretaceous of the Banterwick Barn Chalk borehole, Berkshire, UK. Marine Micropaleontology 47, 271-306. 
Pearce, M.A., Jarvis, I., Tocher, B.A., 2009. The Cenomanian-Turonian boundary event, OAE2 and palaeoenvironmental change in epicontinental seas: new insights from the dinocytst and geochemical records. Palaeogeography, Palaeoclimatology, Palaeoecology 280, 207-234.

Pearce, M.A., Lignum, J.S., Jarvis, I., 2011. Senoniasphaera turonica (Prössl, 1990 ex Prössl, 1992) comb. nov., senior synonym of Senoniasphaera rotundata alveolata Pearce et al., 2003: an important dinocyst marker for the Lower Turonian chalk of NW Europe. Journal of Micropalaeontology 30,91-93.

Peyrot, P., Barroso-Barcenilla, F., Barrón, E., Comas-Rengifo, M.J., 2011.

Palaeoenvironmental analysis of Cenomanian - Turonian dinocyst assemblages from the Castilian Platform (Northern - Central Spain). Cretaceous Research 32, 504-526.

Phillips, J., 1829. Illustrations of the geology of Yorkshire or a tescription of the strata and organic remains of the Yorkshire coast: accomp: nit t by a geological map, sections and plates of the fossil plants and animals ! ? L...llips, York, $192 \mathrm{pp}$.

Pierce, R.L., 1961. Lower Upper Cretaceous plant mic ốcsils from Minnesota. Minnesota Geological Survey, Bulletin 42,1-8\%

Pirrie, D., Crame, J.A., Lomas, S.A., Riding, J.B., 199\%. ' ze Cretaceous stratigraphy of the Admiralty Sound Region, James Ross Basin. Antar ctica. Cretaceous Research 18, 109-137.

Poulsen, N.E., 1993. Dinoflagellate cyst ', st stigraphy of the Oxfordian and Kimmeridgian of Poland. Acta Gt $>$ lr gica Polonica 43, 251-272.

Prasad, B., 1999. Palynological chaı .cterisation, biostratigraphy and depositional environment of Pre-Tertiary lithu 'nits of Krishna - Godavari Basin, India. Geoscience Journal 20, 143-1',4

Price, F.G.H., 1877. On the beds hetween the Gault and Upper Chalk near Folkestone. Quarterly Journal of the Feoiogical Society, London 33, 431-448.

Prince, I.M., 1997. Palyno'?ng 'f the Upper Turonian to Lower Campanian Chalks of Southern England. u. Dublished PhD thesis, University of Wales, Aberystwyth, 334 pp.

Prince, I.M., Jarvis, I., Thr her, B.A., 1999. High-resolution dinoflagellate cyst biostratigraphy of the Santonian: Basal Campanian (Upper Cretaceous): New data from Whitecliff, Isle of Wight, England. Review of Palaeobotany and Palynology $105,143-169$.

Prince, I.M., Jarvis, I., Pearce, M.A., Tocher, B.A., 2008. Dinoflagellate cyst biostratography of the Coniacian-Santonian (Upper Cretceous): new data from the English Chalk. Review of Palaeobotany and Palynology 150, 59-96.

Pross, J., Link, E., Ruf, M., Aigner, T., 2006. Delineating sequence stratigraphic patterns in deeper ramp carbonates: quantitative palynofacies data from the Upper Jurassic, Kimmeridgian) of Southwest Germany. Journal of Sedimentary Research 76, 524538.

Prössl, K.F., 1990. Dinoflagellates of the Cretaceous, (Early Hauterivian to Late Turonian), in the Niedersachsen Basin. Stratigraphy and facies changes of the 
Konrad 101 borehole, as well as several other boreholes from northwest Germany. Paläeontographica Abteilung B 218, 93-101.

Püttman, T., Linnert, C., Dolling, B., Mutterlose, J., 2018. Deciphering Late Cretaceous (Cenomanian to Campanian) coastline dynamics in the southwestern Münsterland (northwest Germany) by using calcareous nannofossils: Eustasy vs local tectonics. Cretaceous Research 87, 174-184.

Pyne, R.S., Whatley, R.C., Wilkinson, I.P., 2003. New species of Ostracoda from the Upper Cretaceous Chalk (Conician to Lower Maastrichtian) of East Anglia, U.K. Revista Espanola de Micropaleontología 35, 87-118.

Radmacher, W., Tyszka, J., Mangerud, G., Pearce, M.A., 2014. Dinoflagellate cyst biostratigraphy of the Upper Albian to Lower Maastrichtian in the southwestern Barents Sea. Marine and Petroleum Geology 57, 109-121.

Raine, J.I., 1977. Palynology of samples from Kawau-1A offchoı ? well. In: Strong, C.P. (Ed.), Biostratigraphy of the Kawau No. 1A offshore vell Lower Hutt. New Zealand Geological Survey 18, 9-15.

Rawson, P.F., 2018. Itinerary 12 Thornwick Bay and ''ortu Landing, Flamborough. In: Rawson, P.F., Wright, J.K., Geology of the Yor' sin' ' ${ }^{\prime} \in$ Coast (4th edition), Geologists' Association Guide 34, 126-131.

Rawson, P.F., Curry, D., Dilley, F.C., Hancock, J ivi, Kennedy, W.J., Neale, J.W., Wood, C.J., Worssam, B.C., 1978. A correlation of Cr, rar,eous rocks in the British Isles Edinburgh. Scottish Academic Pre s, Gt ᄀlogical Society of London, 70pp.

Rawson, P.F., Allen, P., Gale, A.S., 2001. I'. e Chalk Group - a revised lithostratigraphy. Geoscientist, 11, 21.

Razmjooei, M.J., Thibault, N., Kani, A. Dinarès-Turell, J., Pucéat, E., Shahriari, S., Radmacher, W., Jamali, A.M L'ir lann, C.V., Voigt, S., Cocquerez, T., 2018. Integrated bio- and carbc n-isutope stratigraphy of the Upper Cretaceous Gurpi Formation (Iran): A nev reterence for the eastern Tethys and its implications for large-scale correlation ${ }^{f}{ }^{f}$ scage boundaries. Cretaceous Research 91, 312-340.

Reade, J.B., 1839. On so ' it new organic remains in the flint of Chalk. Annals of Natural History 2, 191- 19?

Richards, B.C., Hillier, BY., 2000. Post-drilling analysis of the North Falkland Basin: Part 1: Tectono stratigraphic framework. Journal of Petroleum Geology 23, 253-272.

Riding, J.B., Thomas, J.E., 1988. Dinoflagellate cyst stratigraphy of the Kimmeridge Clay, (Upper Jurassic) from the Dorset Coast, southern England. Palynology 12, 65-88.

Riding, J.B., Crame, J.A., Dettmann, M.E., Cantrill, D.J., 1998. The age of the Base of the Gustav Group in the James Ross Basin Antarctica. Cretaceous Research 19, 87-105.

Riley, L.A., Sarjeant, W.AS., 1972. Survey of the stratigraphical distribution of dinoflagellates, acritarchs and tasmanitids in the Jurassic. Geophytology 2, 1-11.

Riley, L.A., Fenton, J.P.G., 1984. Palynostratigraphy of the Berriasian to Cenomanian sequence at Deep Sea Drilling Project Site 535, Leg 77, southeastern Gulf of Mexico. In: Buffler, R.T., Schlager, W., et al. (Eds), Initial Reports of the Deep Sea Drilling Project, U.S. Government Printing Office, 77, Washington, pp. 675-690. 
Robaszynski, F., Alcaydé, G., Amédro, F., Badillet, G., Damotte, R., Foucher, J.-C., Jardiné, S., Legoux, O., Manivit, H., Monciardini, C., Sornay, J., 1982. Le Turonien de la regiontype: Saumurois et Touraine. Stratigraphie, biozonations, sedimentologie. Bulletin des Centres de Recherches Exploration-Production Elf-Aquitaine 6, 119225.

Robaszynski, F., Bless, M.J.M., Felder, P.J., Foucher, J.-C., Legoux, O., Manivit, H., Meessen, J.P.M.T., Tuuk, L.A. Van der., 1985. The Campanian-Maestrichtian boundary in the chalky facies close to the type-Maestrichtian area. Bulletin des Centres de Recherches Exploration-Production Elf-Aquitaine 9, 1-113.

Robinson, N.D., 1986. Lithostratigraphy of the Chalk Group of the North Downs, southeast England. Proceedings of the Geologists' Association 97, 141-170.

Roncaglia, L., 2002. Lower Maastrichtian dinoflagellates from the Viano Clay Formation at Viano, northern Apennines, Italy. Cretaceous Reseal c: 23, 65-76.

Roncaglia, L., Corradini, D., 1997. Upper Campanian to Ma. str) :htian dinoflagellate zonation in the northern Appennines, Italy. News'etu rs on Stratigraphy 35, 2957.

Roncaglia, L., Field, B.D., Raine, J.I., Schiøler, P., Wil ,Oı. G.J., 1999. Dinoflagellate biostratigraphy of Piripauan-Haumurian ( $\mathrm{Up}_{\mathrm{r}} \cdot$ : Cretaceous) sections from northeast South Island, New Zealand. Cretaceous Research 20, 271-314.

Rowe, A.W., 1900. The zones of the White C'ia" $>r$ the English coast I. Kent and Sussex. Proceedings of the Geologists' Asr v iai’n 16, 289-368.

Rowe, A.W., 1904. The zones of the Whı Chalk of the English coast IV. Yorkshire. Proceedings of the Geologists' Association 18, 193-296.

Rowe, A.W., 1929. The zones of th'. v' 'hice Chalk of Lincolnshire. Naturalist 875, 411439.

Sageman, B.B., Meyers, S.R., A tı. 'r, M.A., 2006. Orbital time scale and new C-isotope record for Cenomanizn - Turonian boundary stratotype. Geology 34, 125-128.

Sageman, B.B., Singer, B.S., : Me jers, S.R., Seiwert, S.E., Walaszczyk, I., Condon, D.J., Jicha, B.R., Obradovich, .D., Sawyer, D.A., 2014. Integrating ${ }^{40} \mathrm{Ar} /{ }^{39} \mathrm{Ar}, \mathrm{U}-\mathrm{Pb}$, and astronomical clu ks in the Cretaceous Niobrara Formation, Western Inter ior Basin, USA, Geolno,cal Society of America Bulletin 126, 956-973.

Sarjeant, W.A.S., 1966. Dinoflagellate cysts with Gonyaulax-type Tabulation. In: Davey, R.J., Downie, C., Sarjeant, W.A.S., Williams, G.L., Studies on Mesozoic and Cainozoic Dinoflagellate Cysts. Bulletin of the British Museum (Natural History), Geology, Supplement 3, London, pp. 107-157.

Sarjeant, W.A.S., 1985. The German Aptian dinoflagellate cysts of Eisenack (1958): A restudy. Review of Palaeobotany and Palynology 45, 47-106.

Sarjeant, W.A.S., Stancliffe, R.P.W., 1994. The Micrhystridium and Veryhachium complexes (Acritarcha: Acanthomorphitae and Polygonomorphitae): A taxonomic reconsideration. Micropaleontology 40, 1-77.

Sarjeant, W.A.S., Lacalli, T., Gaines, G., 1987. The cysts and skeletal elements of dinoflagellates: speculations on the ecological causes for their morphology and development. Micropaleontology 33,1-36. 
Sarkar, S., Prasad, B., 2000. Palaeoenvironmental significance of dinoflagellate cysts from the Subathu Formation (Late Ypresian-Middle Lutetian) of Koshalia Nala Section, Shimla Hills, India. Himalayan Geology 21, 167-176.

Schiøler, P., 1992. Dinoflagellate cysts form the Arnager Limestone Formation (Coniacian, Late Cretaceous) Bornholm, Denmark. Review of Palaeobotany and Palynology 72, 1-25.

Schiøler, P., Wilson, G.J., 1998. Dinoflagellate biostratigraphy of the Middle ConiacianLower Campanian (Upper Cretaceous) in South Marlborough, New Zealand. Micropaleontology 44, 313-349.

Schiøler, P., Wilson, G.J., 2001. Dinoflagellate biostratigraphy around the CampanianMaastrichtian boundary at Tercis les Bains, southwest France. In: Odin, G.S. (Ed), The Campanian-Maastrichtian Stage Boundary: characterisation at Tercis les Bains (France): correlation with Europe and other Corıinents. IUGS Special Publication (Monograph) Series 36; Developments i ، Pa' zeontology and Stratigraphy Series 19, Amsterdam, pp. 221-234.

Schlanger, S.O., Arthur, M.A., Jenkyns, H.C., Scholle, P.L.., Iar, 7. The Cenomanian Turonian Oceanic Anoxic event, I. Stratigraphy $7_{1}+d$ distribution of organic carbonrich beds and the marine $\mathrm{d}^{13} \mathrm{C}$ excursion. In: Mar ne Petroleum Source Rocks. Blackwell, Oxford, pp. 371-399.

Scholle, P.A., Arthur, M.A., 1980. Carbon isoto $\%$, fi tctuation in Cretaceous pelagic limestones: potential stratigraphic $7 r_{1} \cdot$ ' petroleum exploration tool. AAPG Bulletin 64, 67-87.

Schrag, D.P., Depaolo, D.J., Richter, F.M., 1々 ?5. Reconstrucing past sea-surface temperatures - correcting for an onesis of bulk marine carbonate. Geochimica et Cosmochimica Acta 59, 226? - .278.

Schrank, E., 1988. Effects of ch€ mı 71 processing on the preservation of peridinioid dinoflagellates: a case fr on the Late Cretaceous of NE Africa. Review of Palaeobotany and Pal;no:'ng 56, 123-140.

Schrank, E., Ibrahim, M.J A., 1095. Cretaceous (Aptian-Maestrichtian) palynology of foraminifera-datt $d \mathrm{w}$, lls (KRM-1, AG-18) in Northwestern Egypt. Berliner Geowissenschatı: he Abhandlungen, Reihe A, Geologie und Paläontologie 177, 144.

Schulz, M.-G., Ernst, G., Ernst, H., Schmid, F., 1984. Coniacian to Maastrichtian stage boundaries in the standard sections for the Upper Cretaceous white chalk of N.W. Germany (Lägerdorf - Kronsmoor - Hemmoor): Definitions and proposals. Bulletin of the Geological Society of Denmark 33, 203-215.

Scotese, C.R., Boucot, A.J., Chen Xu, 2014. Atlas of Phanerozoic Climatic Zones (Mollweide Projection), Volumes 1-6, PALEOMAP Project PaleoAtlas for ArcGIS, PALEOMAP Project, Evanston, IL.

Scott, R.W., Oboh-Ikuenobe, F.E., Benson Jr., D.G., Holbrook, J.M., Alnahwi, A., 2018. Cenomanian-Turonian flooding cycles: U.S. Gulf Coast and Western Interior. Cretaceous Research, 89 191-210. 
Shand, P., Darbyshire, D.P.F., Love, A.J., Edmunds, W.M., 2009. Sr isotopes in natural waters: Applications to source characterisation and water-rock interaction in contrasting landscapes. Applied Geochemistry 24, 574-586.

Shipboard Scientific Party, 2004. Site 1276. In: Tucholke, B.E., Sibuet, J.-C., Klaus, A., et al. (Eds), Proceedings of the Ocean Drilling Project, Initial Reports. Ocean Drilling Program 210, College Station, Texas, pp. 1-358.

Siegl-Farkas, A., 1997. Dinoflagellate stratigrapahy of the Senonian Formations of the Transdanubian range. Acta Geologica Hungarica 40, 73-100.

Singh, C., 1983. Cenomanian microfloras of the Peace River area, northwestern Alberta. Research Council of Alberta, Bulletin 44,322 pp.

Skertchly, S.B.J., 1879. On the Manufacture of Gun Flints. HMSO, London, 80 pp.

Skupien, P., Mohamed, O., 2008. Campanian to Maastrichtiar nalynofacies and dinoflagellate cysts of the Silesian Unit, Outer Weste' $\mathrm{n}$ Carpathians, Czech Republic. Bulletin of Geosciences 83, 207-224.

Slimani, H., 1994. Les dinokystes des Crais du Camparian ? d Danien à Halembaye, Turnhout (Belgique) et à Beutenaken (Pays-Bas, Mémoires pour servir à l'explication des cartes Géologiques et Miniè es c e la Belgique 37, 1-173.

Slimani, H., 2001a. Les kystes de dinoflagellés du campanién au Danien dans la région de Maastricht (Belgique, Pays-Bas) et T Ir.ll out (Belgique): biozonation et corrélation avec d'autres régions en $\mathrm{F}$ urope occidentale. Geologica et Palaeontologica 35, 161-201.

Slimani, H., 2001b. New species of dinofla ${ }_{c}$ Chalks at Hallembaye and Turn: 'nut (Belgium) and at Beutenaken (The Netherlands). Journal of Mic o , alaeontology 20,1-11.

Smelror, M., Jacobsen, T., Rise, I.., ¿karbo, O., Verdenius, J., Vigran, J.O., 1994. Jurassic to Cretaceous stratigraphy oi hallow cores on the More Basin Margin, Mid-Norway. Norsk Geologisk Tidss $\mathrm{kr}_{\text {^}}{ }^{+}$(Norwegian Journal of Geology) 74, 89-107.

Smelror, M., Mørk, A., Monı 'il E., Rutledge, D., Leereveld, H., 1998. The Klippfisk Formation: A neu lith stratigraphic unit of Lower Cretaceous platform carbonates on the western L'reıts Shelf. Polar Research, New Series 17, 181-202.

Smith, A.B., Batten, D.j., L002. Fossils of the Chalk. Second ed. London: The Palaeontological Association, $374 \mathrm{pp}$.

Smith, S.W., 1992. Microplankton from the Cape Lamb Member, López de Bertodano Formatio (Upper Cretaceous), Cape Lamb, Vega Island. Antarctic Science 4, 337353.

Soliman, A., Suttner, T.J., Lukeneder, A., Summesberger, H., 2008. Dinocysts and ammonoids of Upper Cretaceous sediments of the Pemberger Quarry (Krappfeld, Carinthia, Austria). Berichte der Geologischen Bundesanstalt 74, 100-101.

Soliman, A., Suttner, T.J., Lukeneder, A., Summesberger, H., 2009. Dinoflagellate cysts and Ammonoids from Upper Cretaceous sediments of the Pemberger Formation (Krappfeld, Carinthia, Austria). Ann. Naturhist. Mus. Wien 110, 401-421. 
Song, Z.-C., Zheng, Y., Liu, J., 1995. Palynological assemblages across the Cretaceous/Tertiary boundary in northern Jiangsu, Eastern China. Cretaceous Research 16, 465-482.

Soper, N.J., Downie, C., Higgins, A.C., Costa, L.I., 1976. Biostratigraphic ages of Tertiary Basalt on the East Greenland Continental Margin and their relationship to plate seperation in the Northeast Atlantic. Earth and Planetary Science Letters 32, 149157.

Souque, C., Knipe, R.J., Davies, R.K., Jones, P., Welch, M.J., Lorenz, J., 2019. Fracture corridors and fault reactivation: Example from the Chalk, Isle of Thanet, Kent, England. Journal of Structural Geology 122, 11-26.

Sprovieri, M., Sabatino, N., Pelosi, N., Batenburg, S.J., Coccioni, R., Iavarone, M., Mazzola, S., 2013. Late Cretaceous orbitally-paced carbon isoto pe stratigraphy from the Bottaccione Gorge (Italy). Palaeogeography, Palaeoclin ‘ tology, Palaeoecology 379, 81-94.

Steinkraus, W.E., 1980. Biostratigraphy. In: Amato, R.V be hout, J.W. (Eds), Geologic and Operational summary, Cost No. G-1 Well, Georg ss ? :.1k area, North Atlantic OCS. United States Geological Survey, Open-File Renn : 80, 39-52.

Stoian, L.M., 2002. Late Cretaceous-Late Eocene par.r.ofloras from drillhole Troas 1, offshore Otway Basin, South Australia. Minerals and Energy Resources. Government of South Australia. Report 3, o : 2002,1-21.

Stoll, H.M., Schrag, D.P., 2000. High-resr in 'io: stable isotope records from the Upper Cretaceous rocks of Italy and $\mathrm{Sp}_{\mathrm{c}} \eta \eta$. clacial episodes in a greenhouse planet? GSA Bulletin 112, 308-319.

Stover, L.E., Evitt, W.R., 1978. Analmes :f pre-Pleistocene organic-walled dinoflagellates. Stanford Uni sf rsıty Publications, Geological Sciences 15, 1-300.

Stover, L.E., Helby, R.J., 1987a. : arly Cretaceous dinoflagellates from the Vinck-1 Well, offshore Western Aust. . lia. in: Jell, P.A. (Ed.), Studies in Australian Mesozoic Palynology, Association t t Australasian Palaeontologists, Memoir 4, Sydney, pp. 227-260.

Stover, L.E., Helby, K.', . 98 ' $/$ b. Some Early Cretaceous dinoflagellates from the Houtman-1 Well, ${ }^{\prime}$ 'estern Australia. In: Jell, P.A. (Ed.), Studies in Australian Mesozoic Palynoıvgy, Association of Australasian Palaeontologists, Memoir 4, Sydney, pp. 261-295.

Stover, L.E., Brinkhuis, H., Damassa, S.P., Verteuil, L. de, Helby, R.J., Monteil, E., Partridge, A.D., Powell, A.J., Riding, J.B., Smelror, M., Williams, G.L., 1996. Mesozoic - Tertiary dinoflagellates, acritarchs and Prasinophytes. In: Jansonius, J., McGregor, D.C. (Eds), Palynology: Principles and Applications. American Association of Stratigraphic Palynologists 2, 641-750.

Sumbler, M.G., 1999. The Stratigraphy of the Chalk Group in Yorkshire and Lincolnshire. British Geological Survey, Keyworth, Nottingham. Technical Report WN/99/02, 30 pp.

Sun, X., 1994. Paleogene dinoflagellate cysts form the Liaohe Depression, North East China. Palynology 18,67-86. 
Surlyk, F., Rasmussen, S.L., Boussaha, M., Schiøler, P., Schovsbo, N.H., Sheldon, E., Stemmerik, L., Thibault, N., 2013. Upper Campanian-Maastrichtian holostratigraphy of the eastern Danish Basin. Cretaceous Research 46, 232-256.

Tea-Yassia, J., Digbehib, Z.B., Yaoa, K.R., Glohia, B.V., 1999. Study of some Upper Cretaceous palynomorphs from the Côte d'Ivoire offshore basin: biostratigraphical and palæoenvironmental implications. Journal of African Earth Sciences 29, 783798.

Thibault, N., Jarvis, I., Voigt, S., Gale, A.S., Attree, K., Jenkyns, H.C., 2016. Astronomical calibration and global correlation of the Santonian (Cretaceous) based on the marine carbon isotope record. Paleoceanography 31, 847-865.

Thurow, J., Moullade, M., Brumsack, H.-J., Masure, E., Taugourdeau-Lantz, J., Dunham, K., 1988. The Cenomanian-Turonian boundary event (CTBE) at Hole 641A, ODP Leg 103, (Compared with the CTBE interval at Site 398). Ir. ?oillot, G., Winterer, E.L., et al. (Eds), Proceedings of the Ocean Drilling Progra m, isientific Results 103, College Station, pp. 587-634.

Timmcke, T.A., 1981. Palynology of the Lower Cretac o o c ' ebble Shale Unit, Point Barrow, Alaska. United States Geological Survnr, ?pen-File Report 81, 2-115.

Tocher, B.A., 1984. Palynostratigraphy of uppermo + \&lbian to basal Coniacian (Cretaceous) sediments of the western An $\sigma_{10}-P a r$ is Basin. Unpublished PhD thesis, City of London Polytechnic, London, 22 ? pp

Tocher, B.A., 1987. Campanian to Maes ... ht. $n$ dinoflagellate cysts from the United States Atlantic margin, Deep Sea ?r: ling Project Site 612. In: Poag, C.W., Watts, A.B., et al. (Eds), Initial Reports of thı Deep Sea Drilling Project, Washington, U.S. Government Printing Office 95, 19-428.

Tocher, B.A., Jarvis, I., 1987. Dinof.a', e rate cysts and stratigraphy of the Turonian (Upper Cretaceous) chalk nt: r Beer, southeast Devon, England. In: Hart, M.B. (Ed.), Micropalaeontology of ( ari nate Environments. Special Publication of the British Micropalaeontologica' So iety, pp. 138-175.

Tocher, B.A., Jarvis, I., 1994a. T,inoflagellate cyst distribution and stratigraphy of the Lower - Middle $C$ snos lanian (Upper Cretaceous) at Fumichon, Normandy, Northern France. Revue de Micropaléontologie 37, 223-232.

Tocher, B.A., Jarvis, I., $1>94$ b. Dinoflagellate cyst distribution from the Lower Turonian (Upper Cretaceous) of Ports, Indre-et-Loire. Bulletin d'Information des Géologues du Bassin de Paris 31, 13-23.

Tocher, B.A., Jarvis, I., 1995. Dinocyst distributions and stratigraphy of two Cenomanian - Turonian boundary (Upper Cretaceous) sections from the Western Anglo-Paris Basin. Journal of Micropalaeontology 14, 97-105.

Tocher, B.A., Jarvis, I., 1996. Dinoflagellate cyst distributions and the AlbianCenomanian boundary (Mid-Cretaceous) at Cordebugle, northwest France and Lewes, Southern England. Journal of Micropalaeontology 15, 55-67.

Torsvik, T.H., Van der Voo, R., Preeden, U., Mac Niocaill, C., Steinberger, B., Doubrovine, P.V., van Hinsbergen, D.J., Domeier, M., Gaina, C., Tohver, E., 2012. Phanerozoic polar wander, palaeogeography and dynamics. Earth-Science Reviews 114, 325368. 
Tsikos, H., Jenkyns, H.C., Walsworth-Bell, B., Petrizzo, M.R., Forster, A., Kolonic, S., Erba, E., Premoli-Silva, I.P., Baas, M., Wagner, T., Sinninghe Damsté, J.S., 2004. Carbonisotope stratigraphy recorded by the Cenomanian - Turonian Oceanic Anoxic Event: correlation and implications based on three key localities. Journal of the Geological Society London 161,711-719.

Uličný, D., Jarvis, I., Gröcke, D.R., Čech, S., Laurin, J., Olde, K., Trabucho-Alexandre, J., Švábenická, L., Pedenychouk, N., 2014. A high-resolution carbon-isotope record of the Turonian stage correlated to a siliciclastic basin fill: Implications for mid Cretaceous sea-level change. Palaeogeography, Palaeoclimatology, Palaeoecology 405, 42-58.

Unwins, P.J.R., Batten, D.J., 1989. Early to mid-Cretaceous palynology of northeast Libya. In: El-Arnauti, A., Owens, B., Thusu, B. (Eds), Subsurface Palynostratigraphy of Northeast Libya, pp. 215-257.

Uramoto, G.-I., Tahara, R., Sekiya, T., Hirano, H., 2013. Carl on sotope stratigraphy of terrestrial organic matter for the Turonian (Upper $r_{r_{L}}$ iuceous) in northern Japan: Implications for ocean-atmosphere $\delta^{13} \mathrm{C}$ trends $\mathrm{d}$ 'rin s the mid-Cretaceous climatic optimum. Geosphere 9, 355-366.

Vajda, V., 2001. Aalenian to Cenomanian terrestric' pa ynofloras of SW Scania, Sweden. Acta Palaeontologica Polonica 46, 403-426.

Valensi, L., 1955. Sur quelques microorganisı ^ s I les silex crétacés du Magdalénien de Saint-Amand (Cher). Bulletin de la So : éte Géologique de France, 6e série 5, 35-40.

Vandergon, M.A., 1986. Microfossil coı 'n' 'ation of Mesozoic and Cenozoic units Arctic National Wildlife Refuge, Northeaste.n Alaska. Alaska Division of Geological and Geophysical Surveys. Public-dau File 86, 1-74.

Venkatachala, B.S., Kumar, A., 198J. As assemblage of dinoflagellate cysts and acritarchs from Dalmiapuram Grey โna'? Cauvery Basin, Tamil Nadu, India. Journal of the Palaeontological Societt ol 'ndia 23, 92-109.

Verdier, J.P., 1970. Addenduı: to the memoir of G. Deflandre and I.C. Cookson. Fossil microplankton from $\iota_{1}$, er Mesozoic and Tertiary sediments of Australia. Cahiers de Micropaléontc 'ogi 4,1-54.

Voigt, S., 2000. Stable ox gen and carbon isotopes from brachiopods of southern England and noruwestern Germany: estimation of Upper Turonian palaeotemperatures. Geological Magazine 137, 687-703.

Voigt, S., Hilbrecht, H., 1997. Late Cretaceous carbon isotope stratigraphy in Europe: correlation and relations with sea level and sediment stability. Palaeogeogr aphy, Palaeoclimatology, Palaeoecology 134, 39-59.

Voigt, S., Wiese, F., 2000. Evidence for Late Cretaceous (Late Turonian) climate cooling from oxygen-isotope variations and palaeobiogeographic changes in Western and Central Europe. Journal of the Geological Society London 157, 737-743.

Voigt, S., Schönfeld, J., 2010. Cyclostratigraphy of the reference section for the Cretaceous white chalk of northern Germany, Lagerdorf - Kronsmoor: A late Campanian - early Maastrichtian orbital time scale. Palaeogeography, Palaeoclimatology, Palaeoecology 287, 67-80. 
Voigt, S., Gale, A.S., Flogel, S., 2004. Midlatitude shelf seas in the Cenomanian-Turonian greenhouse world: Temperature evolution and North Atlantic circulation. Paleoceanography 19, PA4020.

Voigt, S., Gale, A.S., Voigt, T., 2006. Sea-level change, carbon cycling and palaeoclimate during the Late Cenomanian of northwest Europe; an integrated palaeoenvironmental analysis. Cretaceous Research 27, 836-858.

Voigt, S., Aurag, A., Leis, F., Kaplan, U., 2007. Late Cenomanian to Middle Turonian highresolution carbon isotope stratigraphy: New data from the Münsterland Cretaceous Basin, Germany. Earth and Planetary Science Letters 253, 196-210.

Voigt, S., Friedrich, O., Norris, R.D., Schoenfeld, J., 2010. Campanian - Maastrichtian carbon isotope stratigraphy: shelf-ocean correlation between the European shelf sea and the tropical Pacific Ocean. Newsletters on Strrtigraphy 44, 57-72.

Voigt, S., Gale, A.S., Jung, C., Jenkyns, H.C., 2012. Global corrolatın of Upper Campanian Maastrichtian successions using carbon-isotope strá tigr; phy: development of a new Maastrichtian timescale. Newsletters on Stra ag, 7phy 45, 25-53.

Vozzhennikova, T.F., 1967. Iskopaemye peridinei Yü kikn, Melovykh i Paleogenovykh otlozheniy SSSR, Izdatelstvo Nauka, Moscow U.i S.R., 347 pp.

Wagreich, M., Pavlishina, P., Malata, E., 2006. Biostrac: rraphy of the lower red shale interval in the Rhenodanubian Flysch Z', n', of Austria. Cretaceous Research 27, 743-753.

Walaszczyk, I., 2000. Inoceramid bival es it the Turonian/Coniacian boundary: biostratigraphy, events and divers: v trend. Acta Geologica Polonica 50, 421-430.

Walaszczyk, I., Wood, C.J., 1998. Inoci ramids and biostratigraphy at the Turonian/Coniacian bounda $y$ hased on the Salzgitter-Salder Quarry, Lower

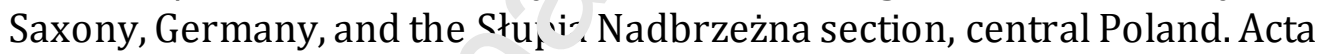
Geologica Polonica 48, 3? ₹-4 4.

Walaszczyk, I., Cobban, W.f. ¿?00. Inoceramid faunas and biostratigraphy of the Upper Turonian - Lower C ^nia ian of the Western Interior of the United States. Special Papers in Palaeor wingy 64, 1-118.

Walaszczyk, I., Wood, $、$ I., $\angle 018$. Inoceramid bivalves from the Coniacian (Upper Cretaceous) of the jtaffhorst shaft (Lower Saxony, Germany) - Stratigraphical significance of a unique succession. Cretaceous Research 87, 226-240.

Walaszczyk, I., Wood, C.J., Lees, J.A., Peryt, D., Voigt, S., Wiese, F., 2010. The SalzgitterSalder Quarry (Lower Saxony, Germany) and Słupia Nadbrzeżna river cliff section (central Poland): a proposed candidate composite Global Boundary Stratotype Section and Point for the Coniacian Stage (Upper Cretaceous). Acta Geologica Polonica 60, 445-477.

Walker, J.C.G., 1986. Global geochemical cycles of carbon, sulfur and oxygen. Mar ine Geology 70, 159-174.

Welch, M.J., Souque, C., Davies, R.K., Knipe, R.J., 2015. Using mechanical models to investigate the controls on fracture geometry and distribution in chalk. In: Agar, S.M., Geiger, S. (Eds), Fundamental Controls on Fluid Flow in Carbonates: Current Workflows to Emerging Technologies. Geological Society of London Special Publication 406, 281-309. 
Wendler, I., 2013. A critical evaluation of carbon isotope stratigraphy and biostratigraphic implications for Late Cretaceous global correlation. Earth-Science Reviews 126, 116-146.

Wetzel, O., 1933. Die in organischer Substanz erhaltenen Mikrofossilien des baltischen Kreide-Feuersteins mit einem sediment-petrographischen und stratigraphischen Anhang. Paläeontographica Abteilung A 78,1-110.

Wetzel, O., 1940. Mikropaläontologische Untersuchungen an der obersenonen Kreide von Stevns Klint-Kridtbrud auf der dänischen Insel Seeland und an ihrem Feuerstein in geschiebekundlicher Hinsicht. Zeitschrift für Geschiebeforschung 16, 118-165.

Whatley, R.C., Pyne, R.S., Wilkinson, I.P., 2003. Ostracoda and palaeo-oxygen levels, with particular reference to the Upper Cretaceous of East A nglia. Palaeogeography, Palaeoclimatology, Palaeoecology 194, 355-386.

Wheeler, J.W., Sarjeant, W.A.S., 1990. Jurassic and Cretace us I alynomorphs from the Central Alborz Mountains, Iran; Their significancf in 'viostratigraphy and palaeogeography. Modern Geology 14, 267-37 .

Whitaker, W., 1865. On the Chalk of Buckinghamsh irt fud on the Totternhoe Stone. Quarterly Journal of the Geological Society or : : idon 21,398-400.

White, H.H., 1842. On fossil Xanthidia. Micros o jical Journal, London 11, 35-40.

White, H.H., 1844. On a new species of foss: Xaıchidium. Transactions of the Microscopical Society of London $1,87$.

Whitham, F., 1991. The stratigraphy of th، Upper Cretaceous Ferriby, Welton and

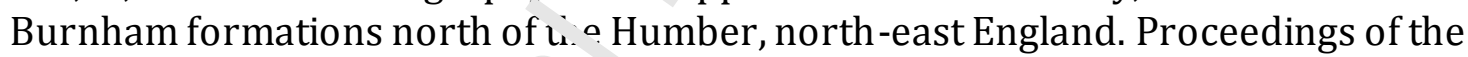
Yorkshire Geological Society 4', 2 2 $7-254$.

Whitham, F., 1993. The stratigr ^p'v of the Upper Cretaceous Flamborough Chalk Formation north of the 'Iu nber, north-east England. Proceedings of the Yorkshire Geological Society 49, ?.5:-258.

Whittlesea, P.S., 1991. The : $1 a$ istrichtian in Norfolk. Bulletin of the Geological Society of Norfolk 40, 33-5:

Wiese, F., Wood, C.J., Ka, lan, U., 2004. 20 years of event stratigraphy in NW Germany; advances and opul questions. Acta Geologica Polonica 54, 639-656.

Wilkinson, I.P., Halliwell, G.P., 1980. Offshore micropalaeontological biostratigraphy of southern and western Britain. Institute of Geological Sciences, Report 79, 1-65.

Wilkinson, I.P., Hine, N.M., Riding, J.B., 1993. Appendix: Cretaceous biostratigraphic biomarkers. In: Johnson, H., Lott, G.K. (Eds), Cretaceous of the Central northern North Sea. Lithostratigraphic Nomenclature of the UK North Sea 2, $187 \mathrm{pp}$.

Wilkinson, S.J., 1849. Observations on Xanthidium, both fossil and recent. Transactions of the Microscopical Society of London 2, 89-92.

Williams, G.L., 1975. Dinoflagellate and spore stratigraphy of the Mesozoic-Cenozoic, offshore eastern Canada. Geological Survey of Canada, Paper 75, 107-161.

Williams, G.L., 1977. Palynological biostratigraphy, Deep Sea Drilling Project, Sites 367 and 370. In: Lancelot, Y., Seibold, E., et al. (Eds), Deep Sea Drilling Project, 
Washington, Initial Reports, U.S. Government Printing Office 38, Washington, pp. 783-798.

Williams, G.L., Brideaux, W.W., 1975. Palynologic analyses of Upper Mesozoic and Cenozoic rocks of the Grand Banks, Atlantic Continental Margin. Geological Survey of Canada, Bulletin 236, 1-162.

Williams, G.L., Bujak, J.P., 1985. Mesozoic and Cenozoic dinoflagellates. In: Bolli, H.M., Saunders, J.B., Perch-Nielsen, K. (Eds), Plankton Stratigraphy. Cambridge University Press, Cambridge pp. 847-964.

Williams, G.L., Stover, L.E., Kidson, E.J., 1993. Morphology and stratigraphic ranger of selected Mesozoic-Cenozoic dinoflagellate taxa in the northern Hemisphere. Geological Survey of Canada, Paper 92, 1-137.

Williams, G.L., Brinkhuis, H., Pearce, M.A., Fensome, R.A., W ‘ c gink, J.W., 2004. Southern Ocean and Global Dinoflagellate Cyst Events compared $1 \mathrm{I}_{1}$ tex events for the Late Cretaceous-Neogene. In: Exon, N.F., Kennett, J.P., Ma on€, M.J. (Eds), Proceedings of the Ocean Drilling Program, Scientific Results 1 бy, 1-98.

Williams, G.L., Fensome, R.A., MacRae, R.A., 2017. The Lenun and Williams Index of fossil dinoflagellates 2017 edition. American Assor ıainn of Stratigraphic Palynologists Foundation, Contribution 48, $1097 \mathrm{pp}$.

Wilmsen, M., 2003. Sequence stratigraphy an if alaeoceanography of the Cenomanian Stage in northern Germany. Cretaceou s : es arch 24, 525-568.

Wilmsen, M., 2007. Integrated stratigr .ph of the upper lower-lower Middle Cenomanian of northern Germany 'nd southern England. Acta Geologica Polonica 57, 263-279.

Wilmsen, M., Niebuhr, B., Wood, C .., Z zwischa, D., 2007. Fauna and palaeoecology of the Middle Cenomanian Praeartin or amax primus Event at the type locality, Wunstorf quarry, northern Germai. 'r. Cretaceous Research 28, 428-460.

Wilson, G.J., 1971. Observatinn: on European Late Cretaceous dinoflagellate cysts. Part 1. In: Farinacci, A. (Ed.), , roceedings of the 2nd Planktonic Conference, Rome, 1970. Edizioni Te', ll scienza 2, Rome, pp. 1259-1275.

Wilson, G.J., 1974. Upp `r uampanian and Maastrichtian Dinoflagellate Cysts from the Maastricht Reginn and Denmark. Unpublished PhD thesis, University of Nottingham, Nottingham, $601 \mathrm{pp}$.

Wilson, G.J., 1975. Palynology of deep-sea cores from DSDP Site 275, Southeast Campbell Plateau. In: Kennett, J.P., Houtz, R.E., et al. (Eds), Initial Reports of the Deep Sea Drilling Project), U.S. Government Printing Office 29, Washington, pp. 1031-1035.

Wilson, G.J., 1976. Late Cretaceous, (Senonian), dinoflagellate cysts from the Kahu itara Tuff, Chatham Islands. New Zealand Journal of Geology and Geophysics 19, 127143.

Wilson, G.J., 1982. Dinoflagellates from an ammonite-bearing float concretion, Tangaruhe Stream, Southern Hawkes Bay. New Zealand Geological Survey 52, 5.

Wilson, G.J., 1984. New Zealand Late Jurassic to Eocene dinoflagellate biostratigraphy A summary. Newsletters on Stratigraphy 13, 104-117. 
Wilson, G.J., 1989. Appendix 1: Dinoflagellate assemblages from the Urewera Group. In: Moore, P.R., et al. (Ed.), Stratigraphy and Structure of Cretaceous (Neocomian Maestrichtian) sedimentary rocks in the Anini-Okaura Stream area, Urewera National Park, New Zealand. New Zealand Journal of Geology and Geophysics 32, 525-526.

Wilson, G.J., Morgans, H.E.G., 1989. Cretaceous - Tertiary boundary at Tawanui Southern Hawkes Bay, New Zealand. New Zealand Geological Survey, Record 40, 29-40.

Wiltshire, T., 1869. On the Red Chalk of Hunstanton. Quarterly Journal of the Geological Society of London 25, 185-192.

Witmer, R.J., Mickey, M.B., Haga, H., 1981. Biostratigraphic correlation of selected test wells of National Petroleum Reserve in Alaska. United States Geological Survey, Open-File Report 81-1165, 1-92.

Wohlwend, S., Hart, M., Weissert, H., 2016. Chemostratigrarhy ${ }^{\prime}$ the Upper Albian to mid-Turonian Natih Formation (Oman) - how auth gen c carbonate changes a global pattern. The Depositional Record 2, 97-11\%.

Wood, C.J., 1992. Upper Cretaceous (Chalk). In: Geolc 'v o the Country around Kingston upon Hull and Brigg Memoir for 1:50 $000 \mathrm{Ge} \boldsymbol{\mu U}_{\varepsilon}$ ical Sheets 80 and 89 (England and Wales). HMSO, London, pp. 77-101.

Wood, C.J., 1996. Upper Cretaceous: Chalk Gr, u... In: London and the Thames Valley. 4th ed. HMSO, London, pp. 76-91.

Wood, C.J., Smith, E.G., 1978. Lithostra+ ${ }^{+}$gr; phıal classification of the Chalk in North Yorkshire, Humberside and Lincoı, shire. Proceedings of the Yorkshire Geological Society 42, 263-287.

Wood, C.J., Mortimore, R., 1988. Cr a) blostratigraphy. In: Geology of the country

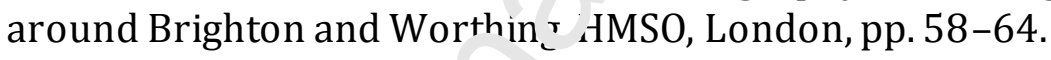

Wood, C.J., Mortimore, R.N., 1 ) ב- An anomalous Black Band succession (Cenomanian Turonian boundary ir. ${ }^{+}$r . $:$l) at Melton Ross, Lincolnshire, eastern England and its international signific nnc. Berlin Geowiss Abh Reihe E.16 Gundolf Ernst Festschrift, pp. 27\%-28,

Wood, C.J., Ernst, G., Ku seınann, G., 1984. The Turonian - Coniacian stage boundary in Lower Saxony (re many) and adjacent areas: the Salzgitter - Salder Quarry as a proposed international standard section. Bulletin of the Geological Society of Denmark 33, 225-238.

Wood, C.J., Morter, A.A., Gallo is, R.W., 1994. Appendix 1. Upper Cretaceous stratigraphy of the Trunch borehole. TG23SE8. In: Geology of the Country around Great Yarmouth Memoir for 1:50,000 Sheet 162 (England and Wales) with an Appendix on the Trunch Borehole by Wood and Morter. HMSO, London, pp. 105-110.

Wood, C.J., Batten, D.J., Mortimore, R.N., Wray, D.S., 1997. The stratigraphy and correlation of the Cenomanian - Turonian boundary interval succession in Lincolnshire, northern England. Freiberger Forschungshefte Reihe C 468, 333346.

Wood, S.E., Askin, R.A., 1992. Dinoflagellate cysts from the Marambio Group, (Upper Cretaceous) of Humps Island. Antarctic Science 4, 327-336. 
Wood, S.E.L., Riding, J.B., Fensome, R.A., Williams, G.L., 2016. A review of the Sentusidinium complex of dinoflagellate cysts. Review of Palaeobotany and Palynology 234, 61-93.

Woods, H., 1896. The Mollusca of the Chalk Rock: Part I. Quarterly Journal of the Geological Society of London 52, 68-98.

Woods, M.A., Chacksfield, B.C., 2012. Revealing deep structural influences on the Upper Cretaceous Chalk of East Anglia (UK) through inter-regional geophysical log correlations. Proceedings of the Geologists' Association 123, 486-499.

Woods, M.A., Mortimore, R.N., Wood, C.J., 2012. The Chalk of Suffolk. In: A Celebration of Suffolk Geology: GeoSuffolk 10th Anniversary Volume. GeoSuffolk, Ipswich, pp. 105-131.

Wray, D.S., 1999. Identification and long-range correlation (f f bentonites in Turonian Coniacian (Upper Cretaceous) chalks of northwest Eurnp. Geological Magazine 136, 361-371.

Wray, D.S., Wood, C.J., 1998. Distinction between detrit $1 \mathrm{l}$ ar d volcanogenic clay-rich beds in Turonian - Coniacian chalks of eastern "'ngland. Proceedings of the Yorkshire Geological Society 52, 95-105.

Wrenn, J.H., Hart, G.F., 1988. Paleogene dinoflagellatt ryst biostratigraphy of Seymour Island, Antarctica. In: Feldmann, R.M., Wor dburne, M.O. (Eds), Geology and Paleontology of Seymour Island, Antar a : P eninsula. Geological Society of America, Memoir 169, 321-447.

Wright, C.W., 1979. The ammonites of $t_{1}$. English Chalk. Bulletin of the British Museum Natural History (Geology) 31, ?81-332.

Wright, C.W., Wright, E.V., 1942. T'ı ' 'halk of the Yorkshire Wolds. Proceedings of the Geologists' Association 53 11.'-127.

Wright, C.W., Kennedy, W.J., 2015 The Ammonoidea of the Lower Chalk, Part 6. Monograph of the Palreu - tographical Society London 169, 404-460.

Wright, C.W., Kennedy, W.ı., 2r 17. The Ammonoidea of the Lower Chalk, Part 7. Monograph of the Paı leontographical Society London 171,461-561.

Xu, J., Pan, Z., Yang, Y., Li u, Y., Fan, N., 1997. On the Paleogene microphytoplankton from the Shengli oil-bearing region, Shandong, China, pp. 1-241.

Yun, H.-S., 1981. Dinoflagellates of the Upper Cretaceous (Santonian), of Westfalen. Paläeontographica Abteilung B 177, 1-89.

Yun, H.-S., Byun, H., Park, Y.A., 2000. Paleoenvironments interpretation based on microfossil assemblages from intertidal sediments of the Haenam Bay. Journal of the Paleontological Society of Korea 16, 123-144.

Zinsmeister, W.J., Camacho, H.H., 1982. Late Eocene (to possibly Earliest Oligocene) molluscan fauna of the La Meseta Formation of Seymour Island, Antarctic Peninsula. In: Craddock, C. (Ed.), Antarctic Geoscience. International Union of Geological Sciences, Series B, pp. 299-304.

Žítt, J., Nekvasilová, O., Bosák, P., Svobodová, M., Štemproková-Jírová, D., Štastny, M., 1997. Rocky coast facies of the Cenomanian-Turonian boundary interval at Velim, 
(Bohemian Cretaceous Basin, Czech Republic). Second Part. Vestnik Ceskeho Geologickeho Ústavu (Bulletin of the Czech Geological Survey) 72, 141-155.

Žítt, J., Vodrážka, R., Hradecká, L., Svobodová, M., Zágoršek, K., 2006. Late Cretaceous environments and communities as recorded at Chrtníky (Bohemian Cretaceous Basin, Czech Republic). Bulletin of Geosciences 81, 43-79. 


\section{List of Figures and Tables}

Fig. 1. Chalk provinces and the geology of north Norfolk showing the location of the Trunch borehole. Geological map based on Peake and Hancock (1961,1970), inset map modified from Mortimore and James (2015) and Mitchell (2019).

Fig. 2. Stratigraphic framework of the English Chalk with the key markers identified in the Trunch succession and their lateral equivalents in the Northern and Southern Provinces. Dark blue vertical bar indicates the stratigraphir extent of the study interval in the Trunch borehole. Named marker beds follow the North $r n$ Province stratigraphy (Wood and Smith, 1978; Gaunt et al., 1992), with central E ct . tnglia Transitional Province (Woods et al., 2012) and Southern Province (1.'nr.imore, 1986; Mortimore et al., 2001) named equivalents indicated where app up ilate. B1 - B5 are bentonitic marls (Wray and Wood, 1998; Wray, 1999). Not to scalf. $\mathrm{s}^{\prime h} \mathrm{~h}=$ Albian, HFm = Hunstanton Formation. Modified from Woods et al. (201:)

Fig. 3. Cretaceous stratigraphy of the Tr nch borehole I: Albian to Upper Coniacian 515 - $375 \mathrm{~m}$ depth. Lithology based on th - detailed logs of Morter et al. (1975; http://scans.bgs.ac.uk/sobi_scans/1,o eholes/517419/images/12114521.html). Macrofossil records from Mor $r$ et al. (1975) and Wood et al. (1994). Named carbon stable-isotope events after forvi- et al. (2006). B1 - B5 are bentonitic marls (Wray and Wood, 1998; Wray, 199n, rismed marker beds follow the Northern Province

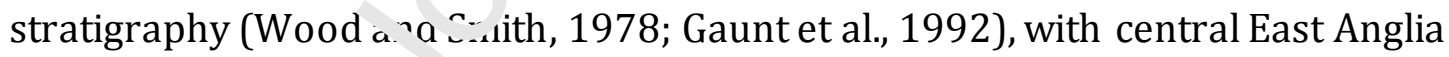
Transitional Province ?'Voods et al., 2012) and Southern Province (Mortimore, 1986; Mortimore et al., 2001) named equivalents indicated where appropriate (Fig. 2). See text for further stratigraphic details. LJ = Lower Jurassic, $\mathrm{A}=$ Albian, $\mathrm{Ce}=$ Cenomanian, UCe = Upper Cenomanian, $\mathrm{LTu}=$ Lower Turonian, $\mathrm{MCo}=$ Middle Coniacian, $A j=$ Acanthoceras jukes-brownei, $\mathrm{Cg}=$ Calycoceras guerangeri, $\mathrm{Mg}=$ Metoicoceras geslinianum, $\mathrm{Mcg}=$ Micraster coranguinum Zone, Iv = Inoceramus virgatus. Green horizontal bands indicate extent of positive carbon isotope events (CIE), cream bands are negative CIEs (Jarvis et al., 2006): VBE = Virgatus Beds Event; MCEI = MidCenomanian Event I; PBE = P/B Break Event; MCEII = Mid-Cenomanian Event II; JBE = Jukes-brownei Event; ME = Monument Event; CTBE = Cenomanian - Turonian 
Boundary Event; $\mathrm{Cb}=$ Caburn Event; HW2 and HW3 are Hitch Wood Events 2 and 3 of Uličný et al. (2014). See Fig. 4 for lithological key.

Fig. 4. Cretaceous stratigraphy of the Trunch borehole II: Upper Coniacian to Lower Campanian 375 - 270 m depth. See Fig. 2 for sources of stratigraphic data and presentational information. Op = Offaster pillula, SCBEa = Santonian - Campanian Boundary Event peak a, SCBEb = peak b (following Thibault et al., 2016).

Fig. 5. Stratigraphic summary, carbonate $\delta^{13} \mathrm{C}, \delta^{18} \mathrm{O}$ and ${ }^{87} \mathrm{Sr} /{ }^{86} \mathrm{Sr}$ profiles, and carbon isotope events for the Cenomanian - Lower Campanian of the Trunch borehole. Age model after Table 1. Carbon (blue) and oxygen (red) isoto ${ }_{\mathrm{r}} \mathrm{r}$, rofiles and carbon isotope events (CIEs) after Jarvis et al. (2006); HW2 a n.' H'V3 CIEs following Uličný et al. (2014); SCBE and Pillula CIE from Thibault et $\mathrm{a}^{\prime} \cdot\left(\iota^{2} \_6\right)$. Thin coloured lines join individual data points; underlying paler blue and reu 'ines are 3-point moving averages. Strontium isotope data (filled circles with err $\jmath^{2}$ b ars) from McArthur et al. (1993b). Chalk Sr-isotope data (white filled circl , s; a n corrected for diagenesis by subtracting $30 \times 10^{-6}$ from the measured ${ }^{87} \mathrm{Sr} /{ }^{86} \mathrm{Sr} v_{c}$.ues (cf. McArthur et al., 1993a); fossil data (yellow filled circles) are uncorrectec Orange line connects individual data points. The thick yellow line indicates the prin rr sr-isotope trend based on US Western Interior data (McArthur et al., 1994), wi. ich underpin the global Sr-isotope reference curve (McArthur et al., 2001, 201乞). Leviation of the Trunch data from the reference curve in the Cenomanian and Tur $\eta_{1 \ldots i}$ and is attributed to diagenesis (see text for discussion).

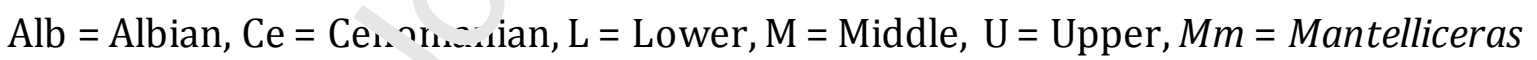
mantelli, $M d=M$. dixoi: $; A r=$ Acanthoceras rhotomagense, $M=$ Mytiloides labiatus, $\mathrm{B} 1$ B6 are regional bentonitic marl marker beds (Wray and Wood, 1998). Note the interval of poor palynological recovery spanning the Upper Cenomanian - lower Upper Turonian. See Table 1 for numerical age assignments.

Fig. 6. Cenomanian - Lower Campanian stratigraphy and selected dinoflagellate cyst ranges in the Trunch borehole. Vertical grey bars join the lowest and highest occurrences of stratigraphically important dinocyst taxa; these do not necessarily correspond to evolutionary inception or extinction levels (see text for discussion). The 
staggered labelling of taxa, for clarity, does not imply more restricted ranges. Refer to Figs 2 - 5 for stratigraphic assignments and abbreviations.

Fig. 7. Absolute organic walled dinoflagellate cyst abundance, species richness and diversity for the Cenomanian - Lower Campanian of the Trunch borehole. Intervals of peak abundance are indicated by the thick green lines. Carbonate-corrected abundance data are plotted for comparison but follow the same trend as the uncorrected curve. Shannon Index calculated using PAST software (Hammer et al., 2001). Refer to Figs 2 5 for stratigraphic assignments and abbreviations.

Fig. 8. Depth vs. age plot for the Cenomanian - Lower Cam ${ }_{\iota_{1}}$ ar ian of the Trunch borehole. The positions of dinocyst datum levels and e +ir ated sediment accumulation rates are shown. Calibration was achieved using $2 \mathrm{Ja}_{\mathrm{c}}^{\mathrm{T}}$-control points for the Upper Cretaceous (Table 1) derived from radioisotopic -nu ₹strochronological ages of macrofossil biostratigraphic datum levels, glc $b_{i}$ arbon-isotope excursions, and the base Chron C32 geomagnetic reversal ( $x$ s s ction 4.5 for methodology).

Fig. 9. English Chalk $\delta^{13} \mathrm{C}_{\text {carb }}$ referenc c curve and carbon-isotope event (CIE) stratigraphy of the Late Albian - Ed ly campanian. The curve and isotope stratigraphy of Jarvis et al. (2006) has been, acaubrated against age using recently published chronological constraints (s e saction 4.5 for methodology).

Fig. 10a-h. Distribul' $n$... ap of (a) Sindridinium borealis (base Cenomanian map); (b) Disphaeria munda ?ase Cenomanian map); (c) Hapsocysta peridictya (base Turonian map); (d) Epelidosphaeridia spinosa (base Turonian map); (e) Cribroperidinium? edwardsii (base Turonian map); (f) Litosphaeridium siphoniphorum (base Turonian map); (g) Sepispinula ambigua (base Turonian map); (h) Pterodinium crassimuratum (base Turonian map). Site locations rotated from their present-day geographic coordinates using GPlates 2.1. Palaeogeography after Cao et al. (2017); palaeoclimate zones from Scotese et al. (2014). The tabulated summary is provided in Supplemental data 3, see Palynodata Inc and White (2008) for references. 
Fig. 11. Summary of Cenomanian bioevents. $C$ ?ed = Cribroperidinium edwardsii, $C g l=$ Canningia glomerata, $C o b=$ Carpodinium obliquicostatum, Dmu = Disphaeria munda, Esp = Epelidosphaeridia spinosa, Hdic = Hapsocysta dictyota, Hdif = Heterosphaeridium difficile, Hpe = Hapsocysta peridictya, Lsi = Litosphaeridium siphoniphorum, Pce = Pervosphaeridium cenomaniense, Pcr = Pterodinium crassimuratum, Sam = Sepispinula ambigua, Sbo = Sindridinium borealis, Sde = Sentusidinium devonense, Stu $=$ Senoniasphaera turonica, Wca = Wrevittia cassidata. Species events from the Trunch borehole that have been used as events on the English Chalk Reference $\delta^{13} C_{\text {carb }}$ curve are shown in bold and indicated by a red dashed line. Additional events on the English Chalk Reference $\delta^{13} \mathrm{C}_{\text {carb }}$ curve are derived from other sourres isee the text for details).

Fig. 12. Stratigraphic distribution and relative abund $t \mathrm{n}_{\mathrm{i}}^{\circ} \mathrm{J}$ f dinocyst species recorded by Clarke and Verdier (1967) in the Culver Cliff se .av.' with highest occurrences in the Cenomanian - basal Turonian, plotted against the S1 - - arb isotope profile (Jarvis et al., 2001) and CIEs of Jarvis et al. (2006). Samplt ro: itions are based on correlation to a skeleton stratigraphy (Clarke and Verd es 1: 77 text-fig. 2). The taxonomy has been updated. Note that we reinterpret Clarkı and Verdier's (op cit.) illustrated specimen of Baltisphaeridium granulosum (their piste 12 figs 7 - 8; now Prolixospheridium granulosum) to be Prolixosphaeridıu $n$ conulum. See Fig. 2 for full zonal names. GM = Glauconitic Marl, MR = Melbo'ı ^ Rock, PM = Plenus Marls, UG = Upper Greensand.

Fig. 13a-h. Distributior . $\mathfrak{z}_{\mathrm{r}}$ of (a) Wrevittia cassidata; (b) Carpodinium obliquicostatum; (c) is ?t, usphaeridium difficile; (d) Pervosphaeridium cenomaniense; (e) Canningia glomerau; (f) Senoniasphaera turonica; (g) Hapsocysta dictyota; (h) Sentusidinium devonense (all base Turonian maps). Site locations rotated from their present-day geographic coordinates using GPlates 2.1. Palaeogeography after Cao et al. (2017); palaeoclimate zones from Scotese et al. (2014). The tabulated summary is provided in Supplemental data 3, see Palynodata Inc and White (2008) for references.

Fig. 14. Summary of Turonian bioevents. $C g l=$ Canningia glomerata, $C m e=$ Cauveridinium membranniphorum, Hdic = Hapsocysta dictyota, Hdif = Heterosphaeridium difficile, Opu = Oligosphaeridium pulcherrimum, Pce = Pervosphaeridium cenomaniense , Rtr = Raetiaedinium truncigerum, Sco = Stephodinium coronatum, Sde = Sentusidinium 
devonense, $S f i=$ Senoniasphaera filoreticulata, Stu = Senoniasphaera turonica . Species events from the Trunch borehole that have been used as events on the English Chalk Reference $\delta^{13} \mathrm{C}_{\text {carb }}$ curve are shown in bold and indicated by a red dashed line. Additional events on the English Chalk Reference $\delta^{13} C_{\text {carb }}$ curve are derived from other sources (see the text for details).

Fig. 15a-h. Distribution map of (a) Raetiaedinium truncigerum (base Turonian map); (b) Senoniasphaera filoreticulata (base Turonian map); (c) Oligospheridium pulcherrimum (base Coniacian map); (d) Cyclonephelium m?mbraniphorum (base Coniacian map); (e) Stephodinium coronatum (base Coniacinn ..ap); (f) Heterosphaeridium verdieri (base Coniacian map); (g) Collu: ' phaeridium asymmetricum (base Santonian map); (h) Spinidinium echinoideum (Jà a 'santonian map). Site locations rotated from their present-day geograph IC ఒ vordinates using GPlates 2.1. Palaeogeography after Cao et al. (2017); palaeocli na`’ zones from Scotese et al. (2014). The tabulated summary is provided in Supple ${ }^{\prime}$ er tal data 3, see Palynodata Inc and White (2008) for references.

Fig. 16. Summary of Coniacian bioeve. ${ }^{+}$s. Cas $=$Callaiosphaeridum asymmetricum, $\mathrm{Cgl}=$ Canningia glomerata, Hve $=$ Heterus h xeridium verdieri, Mwi = Membranilarnacia wilsonii, Pde = Psaligonyaulax a, flandrei, Pin = Palaeohystrichophora infusorioides, $R f u=$ Raphidodinium fucatum, $S d_{t}$ - sontusidinium devonense, $S e c=$ Spinidinium echinoideum, Sfi $=$ Senoniasphaera filr. ${ }^{+} \mathrm{l}$ ulata, Srm $=$ Spiniferites ramosus subsp. maendriformis . Species events from $t_{1}$ ? ${ }_{1}$ unch borehole that have been used as events on the English Chalk Reference $\delta^{13} \mathrm{C}_{\text {car }}$ curve are shown in bold and indicated by a red dashed line. Additional events on the English Chalk Reference $\delta^{13} C_{\text {carb }}$ curve are derived from other sources (see the text for details).

Fig. 17a-h. Distribution map of (a) Raphidodinium fucatum; (b) Spiniferites ramosus subsp. maendriformis; (c) Psaligonyaulax deflandrei; (d) Renidinium rigidum and Trimuridinium whitenessense; (e) Chatangiella manumii; (f) Cannosphaeropsis utinensis; (g) Senoniasphaera protrusa; (h) Spiniferites porosus (all base Santonian map). Site locations rotated from their present-day geographic coordinates using GPlates 2.1. Palaeogeography after Cao et al. (2017); palaeoclimate zones from Scotese et al. (2014). 
The tabulated summary is provided in Supplemental data 3, see Palynodata Inc and White (2008) for references.

Fig. 18. Summary of Santonian bioevents. Aio =Alterbidinium ioannidesii, Cas $=$ Callaiosphaeridum asymmetricum, $\mathrm{Cca}=$ Cordosphaeridium catherineae, $\mathrm{Cem}=$ Chatangiella eminens, Cma =Chatangiella manumii, Cst $=$ Coronifera striolata, Cut $=$ Cannosphaeropsis utinensis, Dal = Dinopterygium alatum, Dst = Dimidium striatum, Hdif = Heterosphaeridium difficile, Kre=Kleithriasphaeridium readei, Odi=Odontochitina diducta, Opo = Odontochitina porifera, Pde = Psaligonyaulax deflandrei, Pint = Pervosphaeridium intervelum, $R r i=$ Renidinium rigidum, $R s a=$ ?hynchodiniopsis saliorum, Sca = Scriniodinium campanula, Sec = Spinidiniun . or inoideum, Sfi =

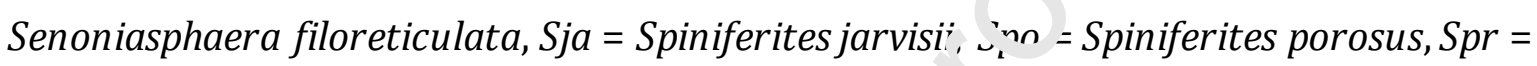
Senoniasphaera protrusa, Srm = Spiniferites ramos's $\mathrm{s}$ ' tusp. maendriformis, Twh = Trimuridinium whitenessense, Wsp = Whitecliffia srin $` a$. Species events from the Trunch borehole that have been used as even $s$ os the English Chalk Reference $\delta^{13} \mathrm{C}_{\text {carb }}$ curve are shown in bold and indicated $r, y, r$ d dashed line. Additional events on the English Chalk Reference $\delta^{13} C_{\text {carb }}$ curve $a_{2}$ a derived from other sources (see the text for details).

Fig. 19a-h. Distribution map गं 'a) Chatangiella eminens; (b) Coronifera striolata; (c) Pervosphaeridium interveluı. (¿) Dimidium striatum; (e) Spiniferites jarvisii; (f) Odontochitina diducta; (s); 'suntochitina porifera; (h) Cordosphaeridium catherineae (all base Campanian map, sic locations rotated from their present-day geographic coordinates using GPlaies 2.1. Palaeogeography after Cao et al. (2017); palaeoclimate zones from Scotese et al. (2014). The tabulated summary is provided in Supplemental data 3, see Palynodata Inc and White (2008) for references.

Fig. 20a-f. Distribution map of (a) Rhynchodiniopsis saliorum; (b) Scriniodinium campanula; (c) Kleithriasphaeridium readei; (d) Whitecliffia spinosa; (e) Alterbidinium ioannidesii; (f) Dinopterygium alatum (all base Campanian map). Site locations rotated from their present-day geographic coordinates using GPlates 2.1. Palaeogeography after Cao et al. (2017); palaeoclimate zones from Scotese et al. (2014). The tabulated 
summary is provided in Supplemental data 3, see Palynodata Inc and White (2008) for references.

Fig. 21. Summary of Early Campanian bioevents. Aio = Alterbidinium ioannidesii, $\mathrm{Cma}=$ Chatangiella manumii, Cut = Cannosphaeropsis utinensis, Kre = Kleithriasphaeridium readei, Rsa $=$ Rhynchodiniopsis saliorum, $S c a=$ Scriniodinium campanula, $S m u=$ Spiniferites multispinulus, Srm = Spiniferites ramosus subsp. maendriformis, $\mathrm{Twh}=$ Trimuridinium whitenessense, Ws $=$ Whitecliffia spinosa. Species events from the Trunch borehole that have been used as events on the English Chalk Reference $\delta^{13} C_{\text {carb }}$ curve are shown in bold and indicated by a red dashed line Ac'itional events on the English Chalk Reference $\delta^{13} C_{\text {carb }}$ curve are derived from $n t_{\text {. }}$ ar sources (see the text for details).

Fig. 22. Cenomanian - Campanian palynological ratu $\boldsymbol{\eta}$ levels for NW Europe: summary of ages and geographic extent. See text for dt ${ }^{r}$ : va ion of age model (Section 4.5) and dating of individual events (Sections 7 1 7.5 ).

Fig. 23. Palaeogeographic distributio of palynological biostratigraphic marker species identified in the Trunch borehole. ؟ it s represent concatenated data from multiple literature sources and adjacenı ${ }^{c_{i}}$ eld or core sections, where available. Site locations were rotated from their pre anı day geographic coordinates (latitude/longitude WGS1984) using GPlates? I (see Section 4.4). Species are grouped into stage intervals based on the age clost $t$ w the species event(s) identified at Trunch; corresponding palaeogeographic disı ioution maps are shown in Figs 10, 13, 15, 17, 19 - 20). Cosmopolitan species placed to the left, more endemic species to the right. Lengths of histogram bars (see key) represent percentage of sites sampling that stage interval from which the species has been recorded. Note the greater number of sites recorded from mid-palaeolatitudes in both hemispheres.

Table 1. Age constraints for the Upper Cretaceous of the Trunch borehole.

\begin{tabular}{ccccccccccc}
\hline Age control point & D & Sa & Sa & Ag & An & Age & Flo & Ag & Tot & References \\
& e & mp & mp & e & ch & floatin & ati & e & al & \\
& p & lin & lin & an & ore & $g$ & ng & co & un & \\
& $t$ & $g$ & $g$ & ch & $d$ & & age & m & cer &
\end{tabular}




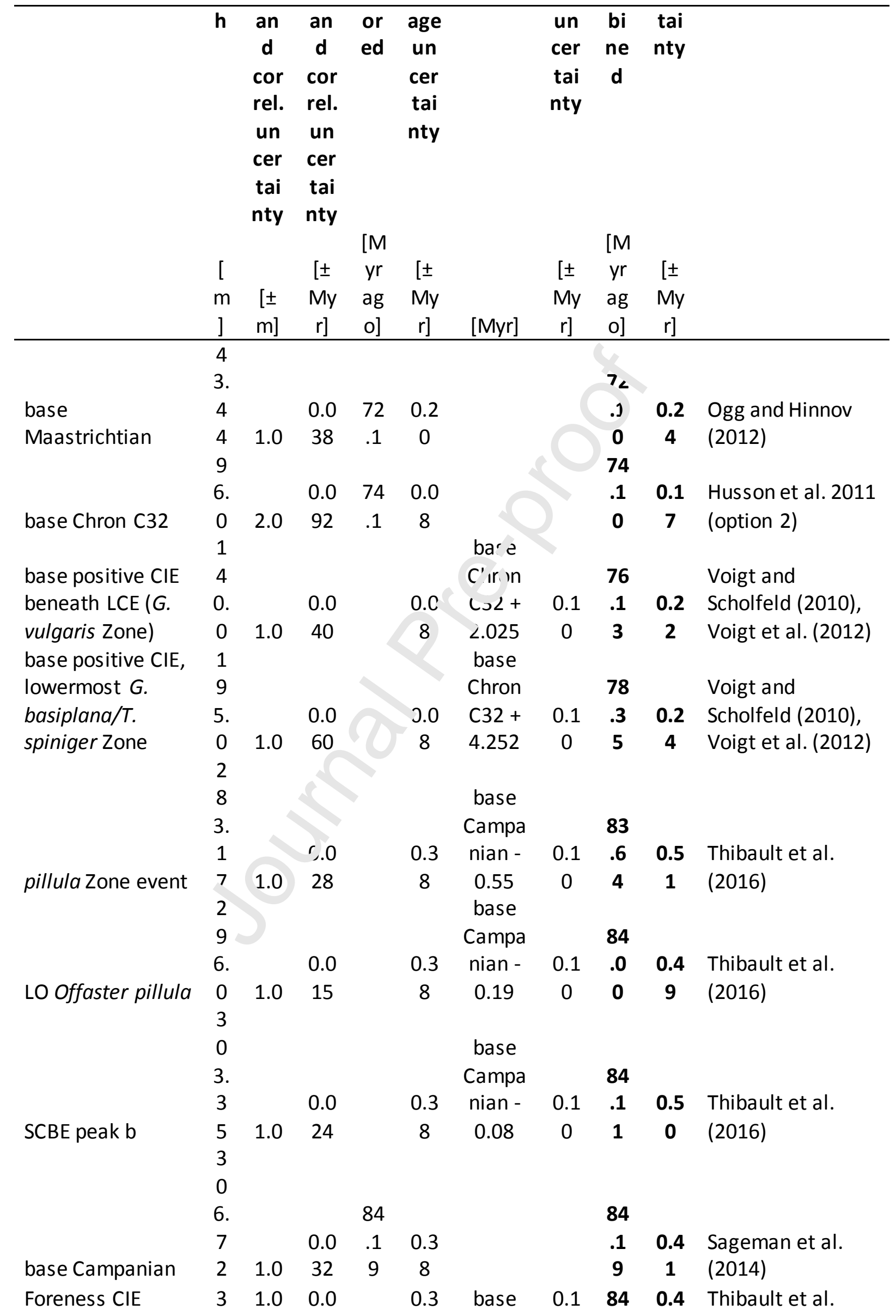




\begin{tabular}{|c|c|c|c|c|c|c|c|c|c|c|}
\hline & 1 & & 11 & & 8 & Campa & 0 & .4 & 9 & (2016) \\
\hline & 4. & & & & & nian & & 5 & & \multirow{8}{*}{$\begin{array}{l}\text { Thibault et al. } \\
(2016)\end{array}$} \\
\hline & 9 & & & & & +0.26 & & & & \\
\hline & 3 & & & & & base & & & & \\
\hline & 2 & & & & & Campa & & 84 & & \\
\hline & 1. & & 0.0 & & 0.3 & nian & 0.1 & .5 & 0.5 & \\
\hline \multirow[t]{2}{*}{ Hawks Brow CIE } & 9 & 1.0 & 23 & & 8 & +0.34 & 0 & 3 & 0 & \\
\hline & 3 & & & & & base & & & & \\
\hline base Buckle CIE & 3 & & & & & Campa & & 84 & & \\
\hline (LO Uintacrinus & 5. & & 0.0 & & 0.3 & nian & 0.1 & .8 & 0.5 & \multirow{4}{*}{$\begin{array}{l}\text { Thibault et al. } \\
(2016)\end{array}$} \\
\hline \multirow[t]{4}{*}{ socialis) } & 9 & 1.0 & 17 & & 8 & +0.66 & 0 & 5 & 0 & \\
\hline & 3 & & & & & base & & & & \\
\hline & 4 & & & & & Campa & & 84 & & \\
\hline & 0. & & 0.0 & & 0.3 & nian & 0.1 & . & 0.5 & \multirow{4}{*}{$\begin{array}{l}\text { Thibault et al. } \\
(2016)\end{array}$} \\
\hline \multirow[t]{3}{*}{ Exceat Flint } & 0 & 1.0 & 21 & & 8 & +0.73 & 0 & 2 & 0 & \\
\hline & 3 & & & & & base & & & & \\
\hline & 4 & & & & & Campa & & 85 & & \\
\hline Horseshoe Bay & 5. & & 0.1 & & 0.3 & nian & $\therefore 1$ & .3 & 0.6 & \multirow{4}{*}{$\begin{array}{l}\text { Thibault et al. } \\
(2016)\end{array}$} \\
\hline \multirow[t]{4}{*}{$\mathrm{CIE}$} & 2 & 2.0 & 17 & & 8 & $+0 . \hat{c}^{1}$ & 0 & 0 & 0 & \\
\hline & 3 & & & & & base & & & & \\
\hline & 5 & & & & & Cin va & & 85 & & \\
\hline & 3. & & 0.0 & & 0.3 & liidn & 0.1 & .6 & 0.5 & \multirow{4}{*}{$\begin{array}{l}\text { Thibault et al. } \\
(2016)\end{array}$} \\
\hline \multirow[t]{4}{*}{ Haven Brow CIE } & 9 & 1.0 & 31 & & 8 & -1.35 & 0 & 7 & 1 & \\
\hline & 3 & & & & & base & & & & \\
\hline & 6 & & & & & Campa & & 85 & & \\
\hline & 5. & & 0.0 & & 0.3 & nian & 0.1 & .9 & 0.5 & \multirow{3}{*}{$\begin{array}{l}\text { Thibault et al. } \\
(2016)\end{array}$} \\
\hline \multirow[t]{4}{*}{ Bedwell CIE } & 9 & 1.0 & 37 & & 8 & +1.72 & 0 & 1 & 2 & \\
\hline & 3 & & & & & base & & & & \\
\hline & 7 & & & & & Campa & & 86 & & \multirow{5}{*}{$\begin{array}{l}\text { Thibault et al. } \\
(2016)\end{array}$} \\
\hline & 2. & & n.c & & 0.3 & nian & 0.1 & .1 & 0.5 & \\
\hline \multirow[t]{4}{*}{ base Santonian } & 6 & 1.0 & $: 8$ & & 8 & +1.97 & 0 & 6 & 2 & \\
\hline & 3 & & & & & base & & & & \\
\hline & 8 & & & & & Campa & & 86 & & \\
\hline & 5. & ) & 0.0 & & 0.3 & nian & 0.1 & .6 & 0.5 & \multirow{3}{*}{$\begin{array}{l}\text { Thibault et al. } \\
(2016)\end{array}$} \\
\hline \multirow[t]{2}{*}{ Kingsdown CIE } & 9 & 1.0 & 71 & & 8 & +2.47 & 0 & 6 & 5 & \\
\hline & 4 & & & & & & & & & \\
\hline Base Middle & 1 & & & & & & & & & \\
\hline Coniacian (East & 1. & & 0.0 & & & & & 88. & 0.5 & \multirow{3}{*}{$\begin{array}{l}\text { interpolated age; } \\
\text { this study }\end{array}$} \\
\hline \multirow[t]{2}{*}{ Cliff Marl 2) } & 5 & 0.5 & 36 & & & & & 42 & 2 & \\
\hline & 4 & & & & & base & & & & \\
\hline base $C$ & 2 & & & & & Coniaci & & 89 & & \multirow{4}{*}{$\begin{array}{l}\text { Laurin et al. } \\
(2014)\end{array}$} \\
\hline schloenbachi & 6. & & 0.0 & & 0.3 & an - & 0.0 & .5 & 0.5 & \\
\hline \multirow[t]{4}{*}{ Zone } & 0 & 1.0 & 64 & & 8 & 0.25 & 6 & 0 & 0 & \\
\hline & 4 & & & & & & & & & \\
\hline & 2 & & & 89 & & & & 89 & & \\
\hline & 9. & & 0.0 & .7 & 0.3 & & & .7 & 0.4 & Sageman et al. \\
\hline base Coniacian & 9 & 1.0 & 51 & 5 & 8 & & & 5 & 3 & (2014) \\
\hline
\end{tabular}




\begin{tabular}{|c|c|c|c|c|c|c|c|c|c|c|}
\hline & 4 & \multicolumn{9}{|c|}{ base } \\
\hline & 3 & & \multirow{2}{*}{\multicolumn{2}{|c|}{0.0}} & \multicolumn{3}{|c|}{ Coniaci } & \multicolumn{2}{|l|}{89} & \multirow{5}{*}{$\begin{array}{l}\text { Laurin et al. } \\
(2014)\end{array}$} \\
\hline & 2. & & & & 0.3 & an & 0.0 & .8 & 0.4 & \\
\hline \multirow[t]{3}{*}{ Didymotis I Event } & 6 & 1.0 & 43 & & 8 & +0.137 & 5 & 9 & 7 & \\
\hline & 4 & & & & & base & & & & \\
\hline & 4 & & & & & Coniaci & & 90 & & \\
\hline base $M$. scupini & 7. & & 0.0 & & 0.3 & an & 0.0 & .5 & 0.5 & Laurin et al. \\
\hline \multirow[t]{3}{*}{ Zone } & 9 & 1.0 & 72 & & 8 & +0.795 & 5 & 5 & 0 & (2014) \\
\hline & 4 & & & & & base & & & & \\
\hline & 5 & & & & & Coniaci & & 90 & & \\
\hline peak Hitch Wood & 2. & & 0.0 & & 0.3 & an & 0.0 & .8 & 0.4 & Laurin et al. \\
\hline \multirow[t]{4}{*}{$\mathrm{CIE}$} & 0 & 1.0 & 14 & & 8 & +1.091 & 8 & 4 & 7 & (2014) \\
\hline & 4 & & & & & base & & & & \\
\hline & 7 & & & & & Coniaci & & $9+$ & & \\
\hline & 0. & & 0.0 & & 0.3 & an & 0.1 &.$j$ & 0.5 & Laurin et al. \\
\hline \multirow[t]{3}{*}{ Bridgewick CIE } & 9 & 0.5 & 24 & & 8 & +1.356 & 4 & 1 & 4 & $(2014)$ \\
\hline & 4 & & & & & & & & & \\
\hline & 7 & & & & & & & 91 & & \\
\hline base I. perplexus & 5. & & 0.0 & & 0.3 & ar. & 0.0 & .3 & 0.5 & Laurin et al. \\
\hline \multirow[t]{3}{*}{ Zone } & 0 & 1.0 & 73 & & 8 & $+1.5 \jmath 5$ & 7 & 1 & 2 & $(2014)$ \\
\hline & 4 & & & & & & & & & \\
\hline & 9 & & & & & & & 92 & & \\
\hline base $C$. woollgari & 7. & & 0.3 & 92 & 0. & $\nabla$ & & .9 & 0.5 & Ogg and Hinnov \\
\hline \multirow[t]{5}{*}{ Zone } & 0 & 1.0 & 26 & .9 & 1 & & & 0 & 3 & $(2012)$ \\
\hline & 5 & & & & & & & & & \\
\hline & 0 & & & & & & & & & \\
\hline & 0. & & & & & & & 93 & & \\
\hline & 0 & & $0 L$ & 33 & 0.1 & & & .9 & 0.2 & Meyers et al. \\
\hline \multirow[t]{3}{*}{ base Turonian } & 7 & 0.2 & 30 & .9 & 5 & & & 0 & 8 & $(2012)$ \\
\hline & 5 & & & & & & & & & Sageman et al. \\
\hline & 0 & & & 94 & & & & 94 & & (2006), Meyers et \\
\hline onset OAE2 & 0. & & 0.0 & .4 & 0.1 & & 0.0 & .4 & 0.2 & al. (2012), Ma et \\
\hline \multirow[t]{4}{*}{ positive $\mathrm{CIE}$} & 9 & $0 .<$ & 71 & 4 & 5 & & 2 & 4 & 4 & al. (2014) \\
\hline & 5 & 3 & & & & & & & & \\
\hline & 0 & & & 96 & & & & 96 & & \\
\hline & 5. & & 0.2 & .1 & 0.2 & & & .1 & 0.4 & Gambacorta et al. \\
\hline \multirow[t]{5}{*}{ MCE I, peak "a" } & 8 & 0.5 & 06 & 9 & 8 & & & 9 & 9 & $(2018)$ \\
\hline & 5 & & & & & & & & & \\
\hline & 1 & & & & & & & & & \\
\hline & 2. & & & 98 & & & & 98 & & \\
\hline & 2 & & 0.2 & .8 & 0.3 & & & .8 & 0.5 & Gambacorta et al. \\
\hline base Cenomanian & 2 & 0.5 & 06 & 4 & 5 & & & 4 & 6 & $(2018)$ \\
\hline
\end{tabular}

placement of the base Maastrichtian and base Chron C32 are derived from carbon-isotope correlation between the borehole and adjacent coastal outcrop sections (Voigt et al., 2012 figs. 5, 6). 


\section{List of plates}

Plate I. 1. Alterbidinium ioannideii Pearce 2010, 298 m. 2. Apteodinium deflandrei (Clarke and Verdier 1967) Lucas-Clark 1987, 364 m. 3. Callaiosphaeridium asymmetricum (Deflandre and Courteville 1939) Davey and Williams 1966b, 507.4 m. 4. Canningia glomerata (Clarke and Verdier 1967) Fensome et al., 2019, 420 m. 5. Cannosphaeropsis utinensis Wetzel 1933, 310 m. 6. Carpodinium obliquicostatum Cookson and Hughes 1964, 504.3 m. 7. Chatangiella ditissima (McIntyre 1975) Lentin and Williams 1976, 403.9 m. 8. Chatangiella eminens Pearce 2010, 332 m. 9. Chatangiella manumii (Vozzhennikova 1967) Lentin and Willa 'ns 1976, 278 m. 10. Cordosphaeridium catherineae Pearce 2010,271 m. 11. Co.'nn fera striolata (Deflandre 1937) Stover and Evitt 1978, 270 m. 12. Cribroperidi il. m? edwardsii (Cookson and Eisenack 1958) Davey 1969a, $433.3 \mathrm{~m}$. Scale bars an $10 \mu \mathrm{m}$.

Plate II. 1. Cribroperidinium wilsonii (Yun Hy ss 981) Poulsen 1996, 397 m. 2. Cyclonephelium membraniphorum Cook u 1 a.d Eisenack 1962b, 458 m. 3. Dimidium striatum (Clarke and Verdier 1967) Pea • e 2010,336 m. 4. Dinogymnium acuminatum Evitt et al. 1967, 280 m. 5. Dinopteryy "um alatum (Cookson and Eisenack 1962b) Fensome et al. 2009,504.3 m. 6. Lis pr ueria munda (Davey and Verdier 1973) Norvick 1976, 507.9 m. 7. Downiesphct. idium armatum (Deflandre 1937) Islam 1993, 397 m. 8. Ellipsodinium rugulosum $\mathrm{Cl}_{a}$ kt and Verdier 1967,504.3 m. 9. Epelidosphaeridia spinosa

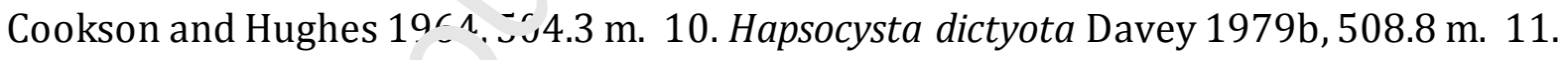
Hapsocysta peridictyu ' $\mathrm{k}:=$ nack and Cookson 1960) Davey 1979b, 504.8 m. 12.

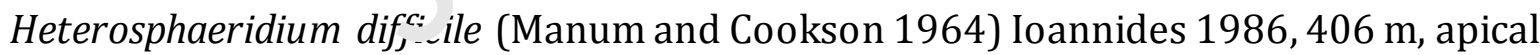
view. Scale bars are $10 \mu \mathrm{m}$.

Plate III. 1. Heterosphaeridium difficile (Manum and Cookson 1964) Ioannides 1986, 406 m, operculum. 2. Heterosphaeridium verdieri Yun Hyesu 1981, 404 m. 3. Hystrichodinium pulchrum Deflandre 1935, 458 m. 4. Hystrichosphaeropsis ovum Deflandre 1935, 319 m. 5. Hystrichosphaeropsis quasicribrata (Wetzel 1961) Gocht 1976, 270 m. 6. Kleithriasphaeridium readei (Davey and Williams 1966b) Davey and Verdier 1976, 508.8 m. 7. Leberidocysta chlamydata (Cookson and Eisenack 1962b) Stover and Evitt 1978, 510.3 m. 8. Leberidocysta defloccata (Davey and Verdier 1973) 
Stover and Evitt 1978,510 m. 9. Litosphaeridium siphoniphorum (Cookson and Eisenack 1958) Davey and Williams 1966b, 507.9 m. 10. Odontochitina diducta Pearce 2010, 280 m. 11. Odontochitina porifera Cookson 1956, $315 \mathrm{~m}$. Scale bars are $10 \mu \mathrm{m}$.

Plate IV. 1. Oligosphaeridium pulcherrimum (Deflandre and Cookson 1955) Davey and Williams 1966b, 431.3 m. 2. Palaeoperidinium pyrophorum (Ehrenberg 1838 ex Wetzel 1933a) Sarjeant 1967b, 424 m. 3. Pervosphaeridium cenomaniense (Norvick 1976) Below 1982c, 507.9 m. 4. Pervosphaeridium intervelum Kirsch 1991, 342.3 m. 5. Pervosphaeridium pseudhystrichodinium (Deflandre 1937) Yun Hyesu 1981, 507.9 m. 6. Psaligonyaulax deflandrei Sarjeant 1966b, 507.9 m. 7. Pterodı ¿im crassimuratum (Davey and Williams 1966a) Thurow et al. 1988,510.3 m. Q. I.aetiaedinium truncigerum (Deflandre 1937) Kirsch 1991, 271 m. 9. Raphidodini ir. fi catum Deflandre 1936b, 312 m. 10-11. Renidinium rigidum Prince et al. 1999, ? د 1 m, 11 ventral view, 12 dorsal view. 12. Rhiptocorys veligera (Deflandre 1937) I əjt ' ne-Carpentier and Sarjeant 1983, $462 \mathrm{~m}$. Scale bars are $10 \mu \mathrm{m}$.

Plate V. 1. Rhynchodiniopsis saliorum Lc 'wye 1997, 308 m. 2. Rugubivesiculites rugosus Pierce 1961, 510.3 m. 3. Scriniodiniu.' campanula Gocht 1959, 465 m. 4. Senoniasphaera filoreticulata (Slina ni 1994) Fensome et al., 2019, 388 m. 5. Senoniasphaera protrusa Clark ₹na Verdier 1967, 317 m. 6-7. Senoniasphaera turonica (Prössl 1990 ex Prössl 199_h) ^earce etal. 2011, 466 m, 6 dorsal view, 7 ventral view. 8. Sentusidinium devoner ro : arce 2018, 418 m. 9. Sentusidinium ringnesiorum (Manum and Cookson 1964) v'n d et al. 2016, 510.3 m. 10. Sepispinula ambigua (Deflandre 1937) Masure in Fauc:..nier and Masure 2004, 506.4 m. 11-12. Sindridinium borealis Nøhr-Hansen et al. 2018, 507.9 m, 11 specimen with an attached operculum, 12 specimen with detached operculum. Scale bars are $10 \mu \mathrm{m}$.

Plate VI. 1. Spinidinium echinoideum (Cookson and Eisenack 1960a) Lentin and Williams 1976, 272 m. 2. Spiniferites jarvisii Pearce 2010, 299 m. 3. Spiniferites multispinulus Pearce 2010, 270 m. 4. Spiniferites porosus (Manum and Cookson 1964) Harland 1973, 451 m. 5. Spiniferites ramosus subsp. maeandriformis (Corradini 1973) Lentin and Williams 1975, 400 m. 6. Spongodinium delitiense (Ehrenberg 1838) Deflandre 1936b, 288 m. 7. Stephodinium coronatum Deflandre 1936a, 451 m. 8. Tenua 
colliveri (Cookson and Eisenack 1960b) Fensome et al. 2019, 511.3 m. 9. Trichodinium castanea Deflandre 1935, 458 m. 10. Trimuridinium whitenessense (Prince et al. 2008) Fensome et al., 2019, 301 m. 11. Whitecliffia spinosa (Clarke and Verdier 1967) Pearce 2010, 286.55 m. 12. Wrevittia cassidata (Eisenack and Cookson 1960) Helenes and Lucas-Clark 1997, $507.9 \mathrm{~m}$. Scale bars are $10 \mu \mathrm{m}$.

\section{Supplementary data}

Table 1. Stable isotopes and carbonate data for the Trunch borehole.

Table 2. Palynology count data for the Trunch borehole ( $\llcorner 12-272 \mathrm{~m}$ ).

Table 3. Geographic location summary.

Table 4. Late Cretaceous age model: age con: tr ai its for the Culver Cliff outcrop section.

Table 5. Late Cretaceous age model: agt ronstraints for the Dover outcrop section.

Table 6. Late Cretaceous age moae'. age constraints for the Eastbourne outcrop section.

Table 7. Late Cretaceous as ' ni del: age constraints for the Speeton outcrop section. 


\section{Highlights}

- a detailed record of Cretaceous organic-walled dinoflagellate cysts is presented

- we propose a new stratigraphy comprising 65 dinocyst events

- absolute ages are assigned to palynological events with a 10 - 100 kyr resolution

- the palaeogeographic distributions of key dinocyst taxa are reviewed and mapped

- $\quad$ specific global, Northern Hemisphere and NW European bioevents are demonstrated 


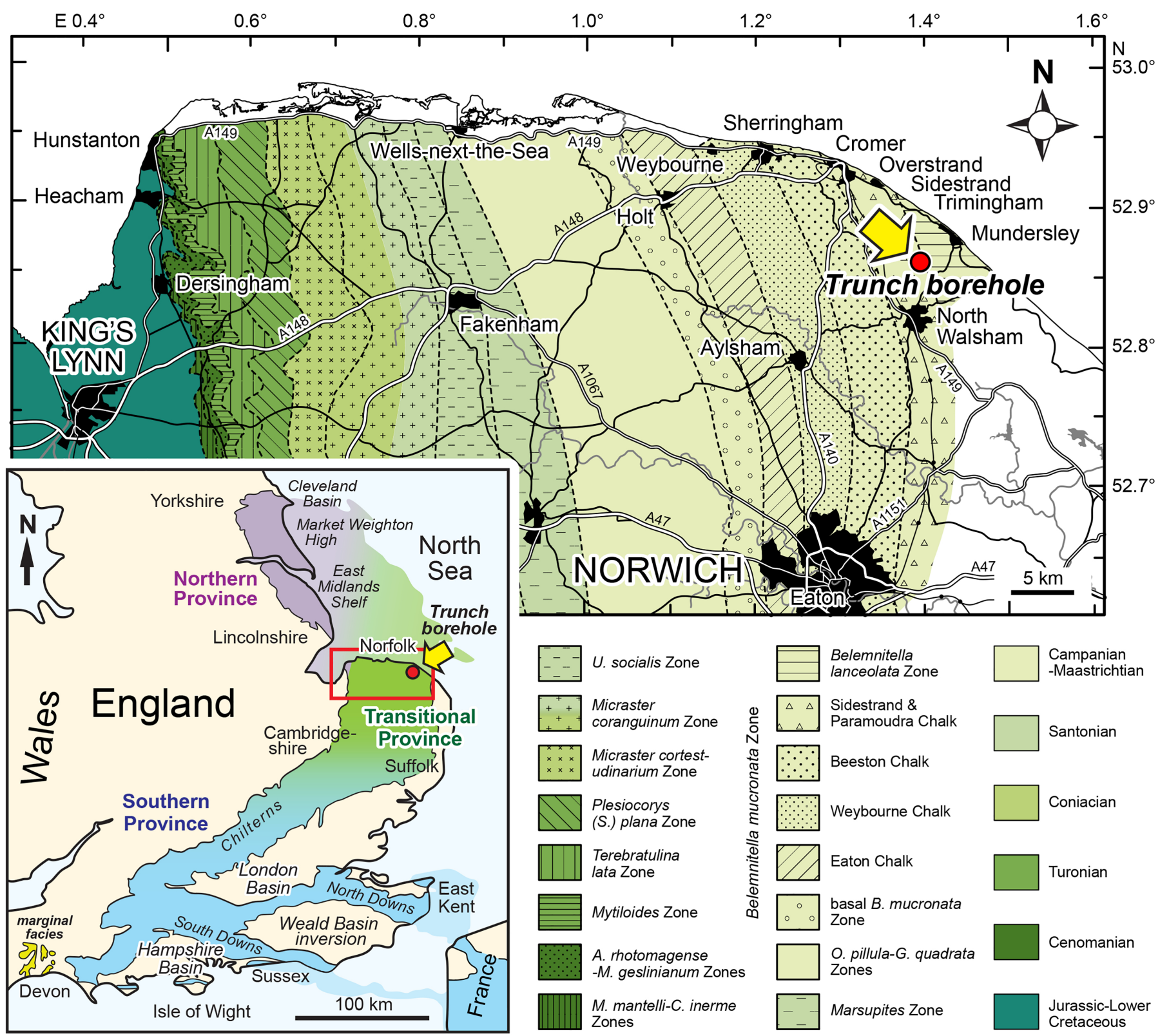




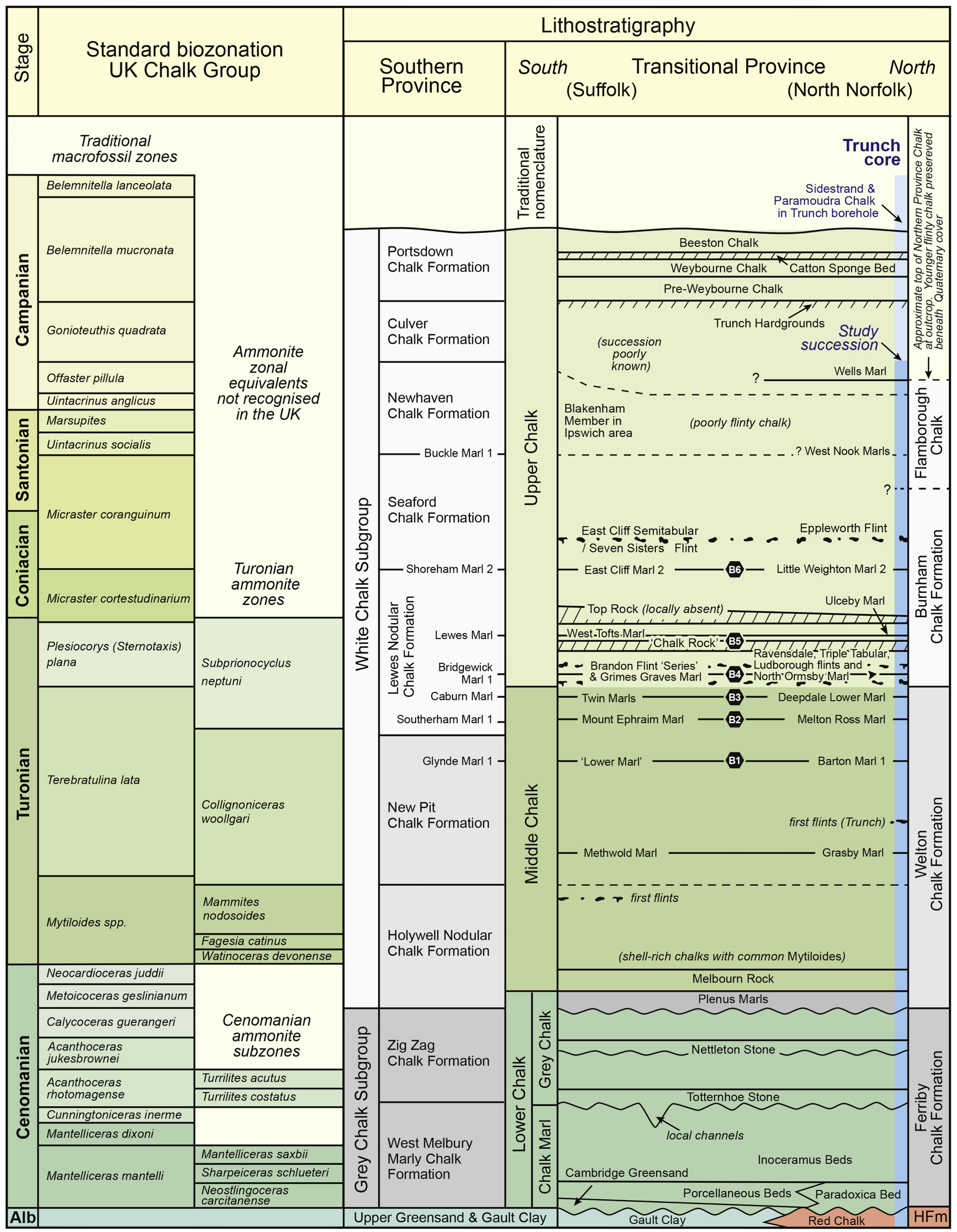




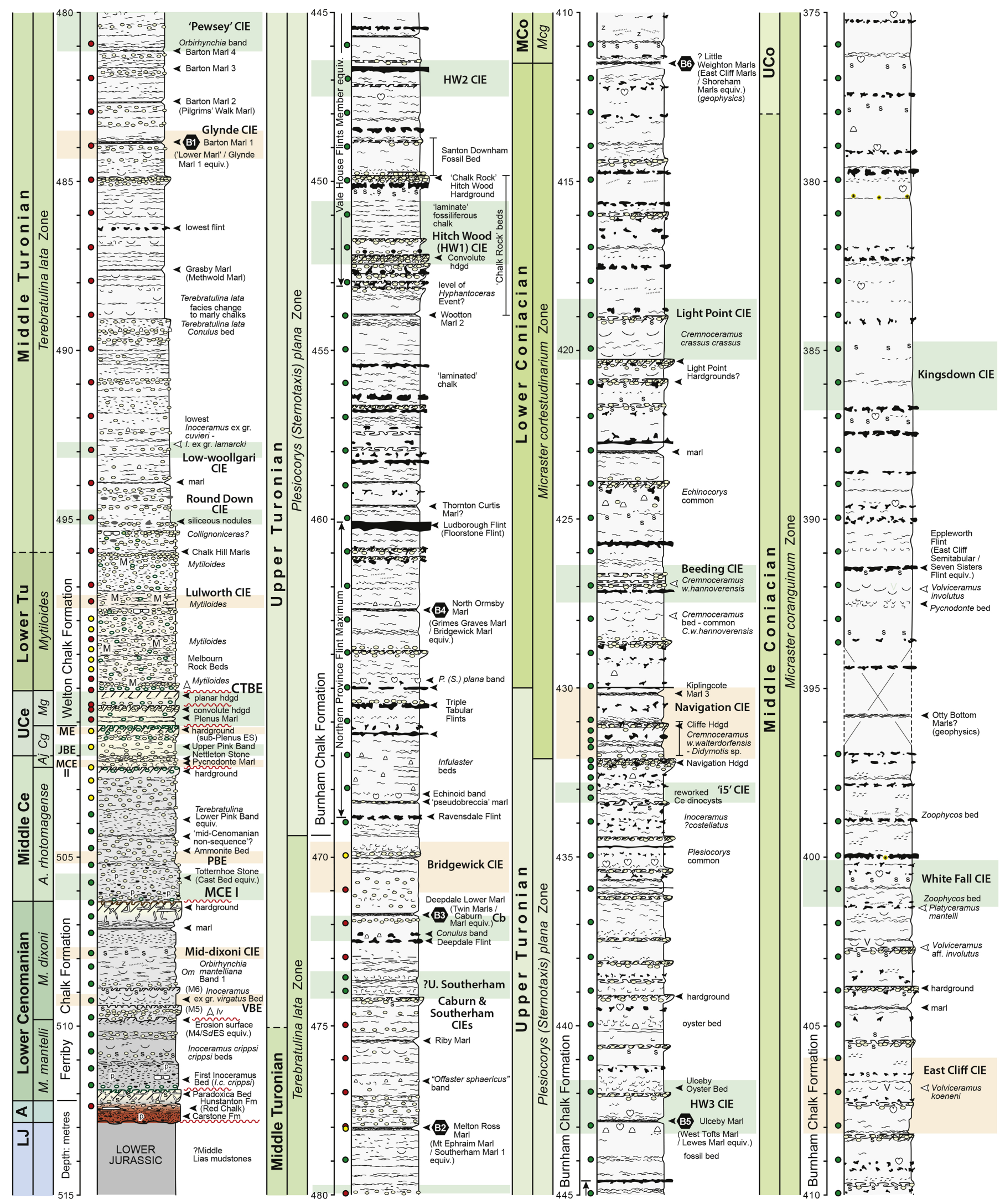




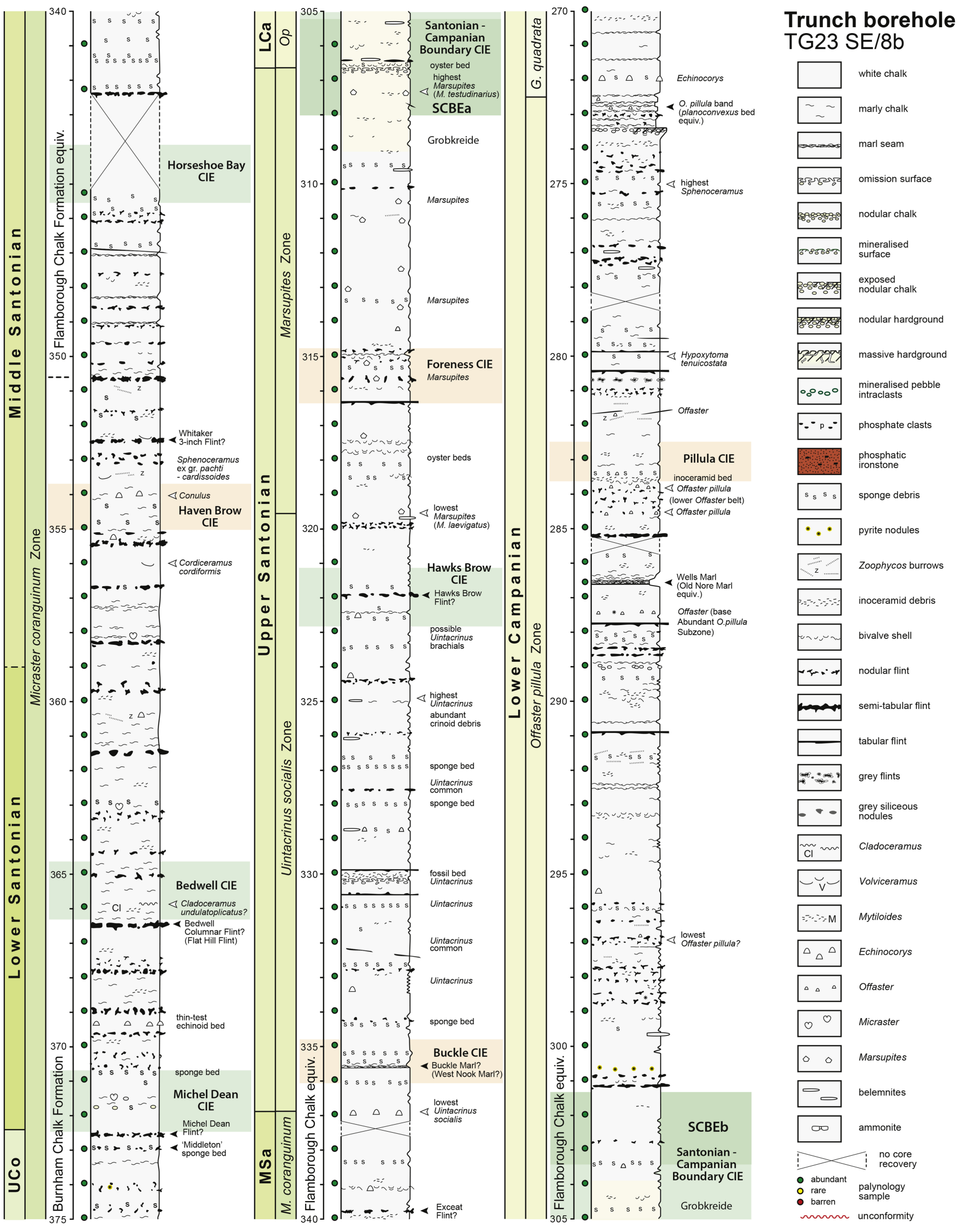




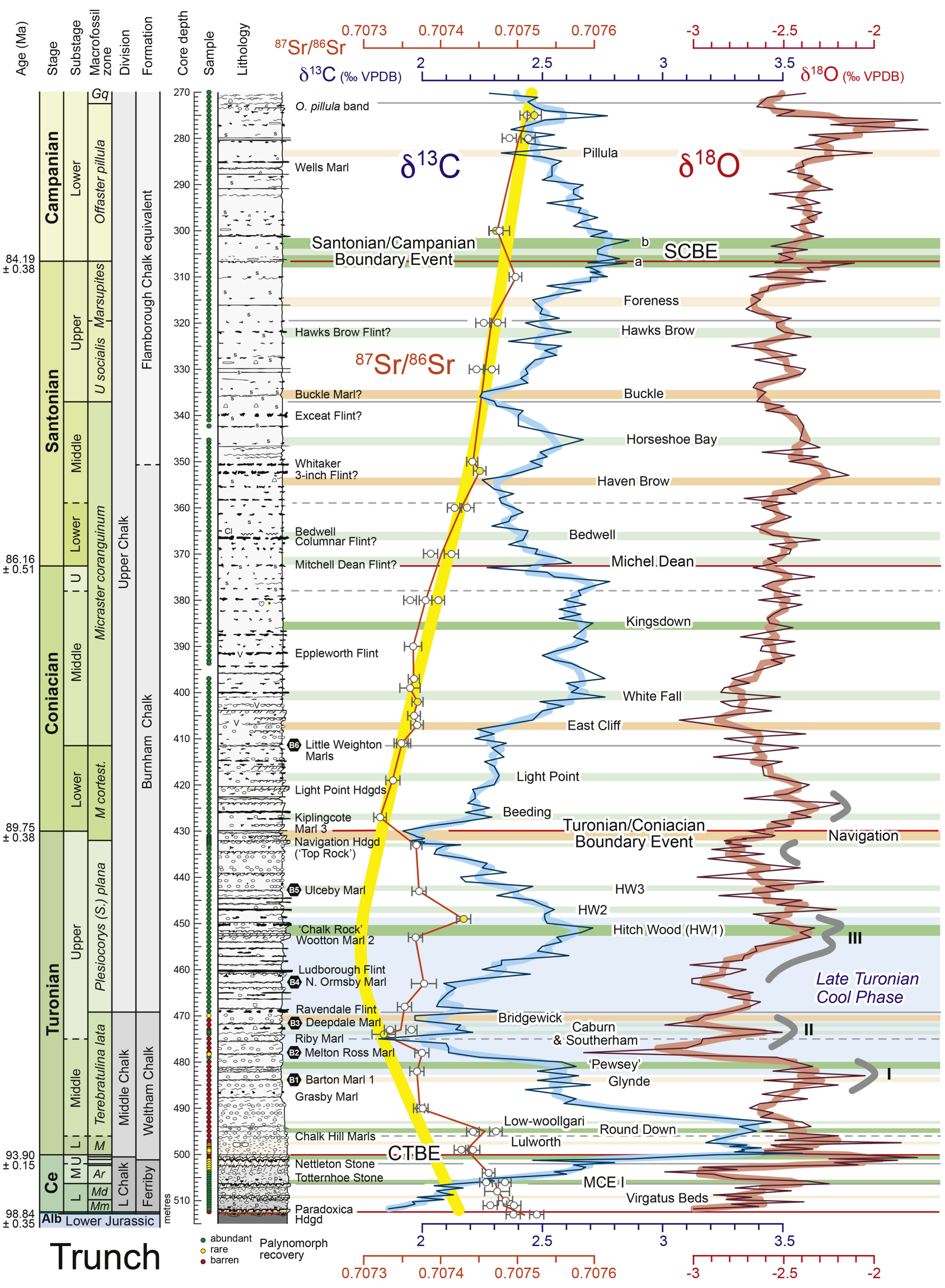

Figure 5 


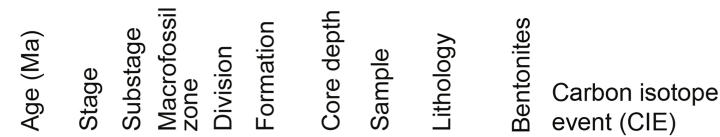

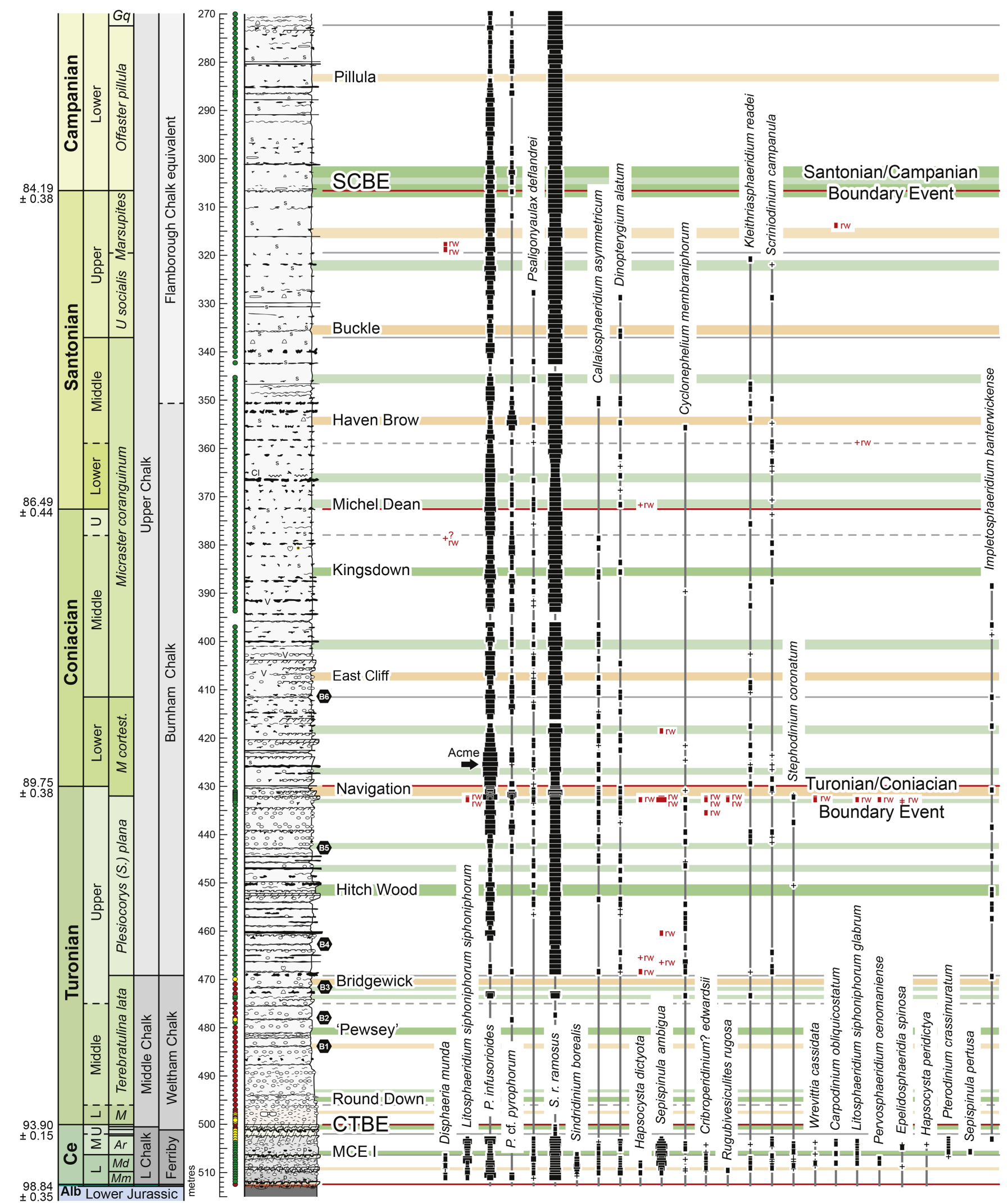


IIH
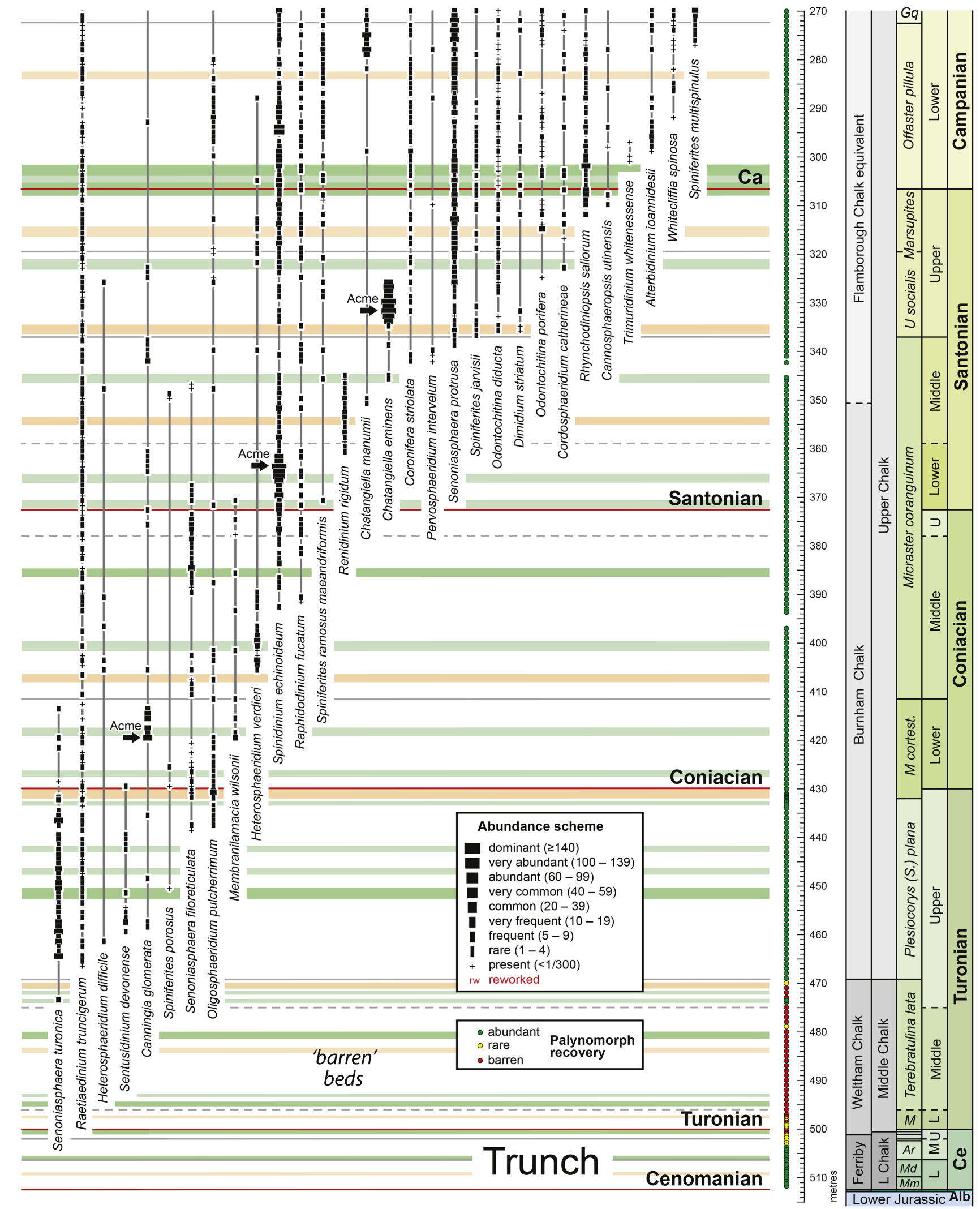
Carbon isotope

Absolute abundance (dpg)

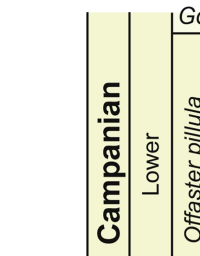

event (CIE)

\begin{tabular}{llllllll|}
\hline & & 5 & & 10 & & 15 \\
\hline & & & & & & & \\
0 & 2 & 4 & 6 & 8 & 10 \\
\hline & & & & & & &
\end{tabular}

bulk sediment $\left(\times 10^{3}\right)$ (red)
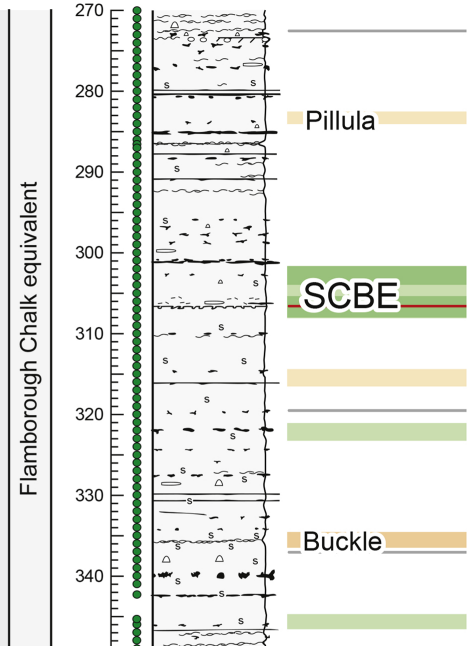

$800=-2$

360 E-

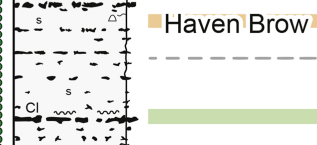

370 E 8 - $\div \div$

- s. - - st -Michel.Dean-

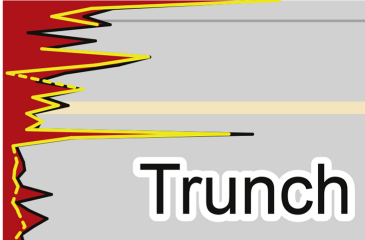

\section{SCBE}

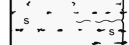

$=\cdots-1=$ Kingsdown

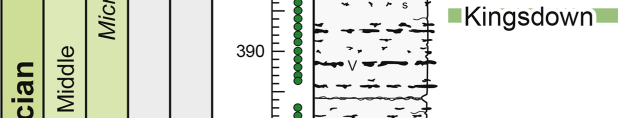

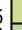

93.90
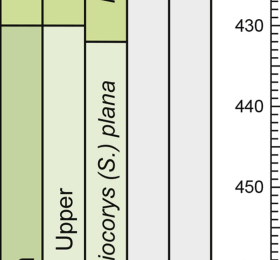

$\frac{\frac{5}{\frac{5}{2}}}{\frac{5}{\frac{0}{3}}}$

\section{는}

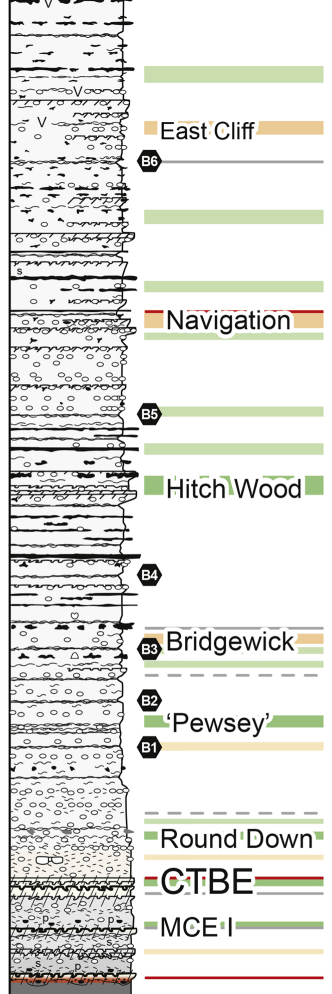

Dinocyst abundance and diversity

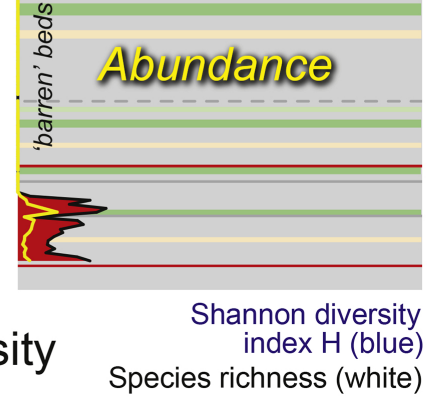

carbonate corrected $\left(\times 10^{5}\right)$ (yellow)
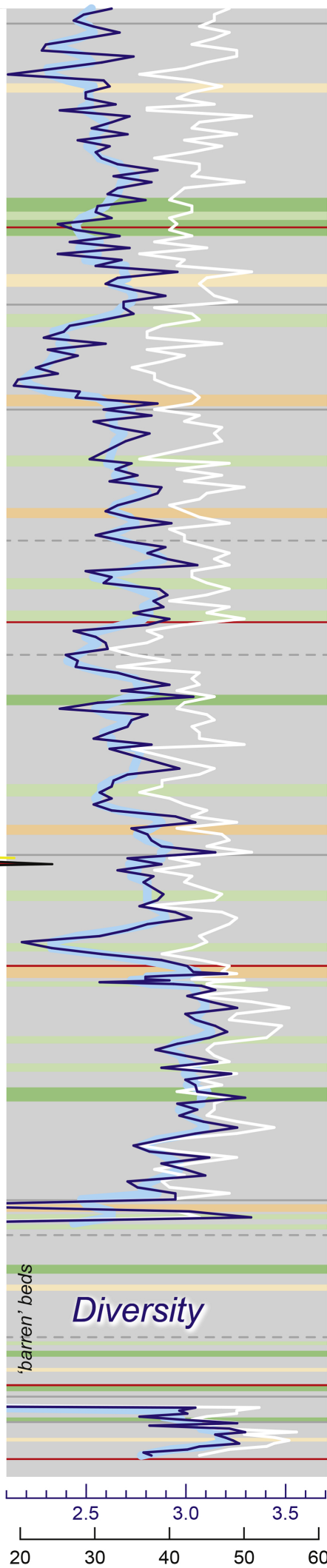


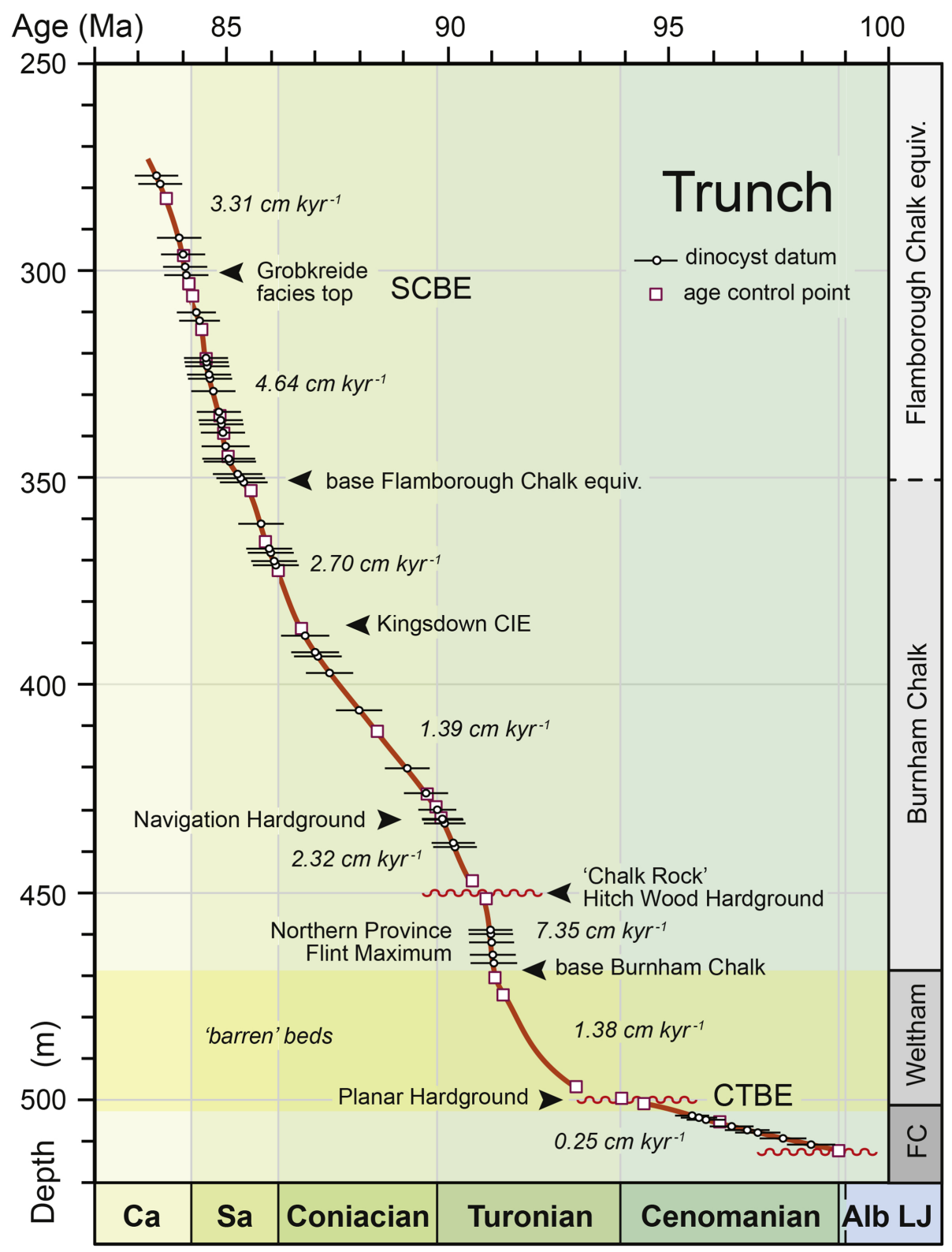




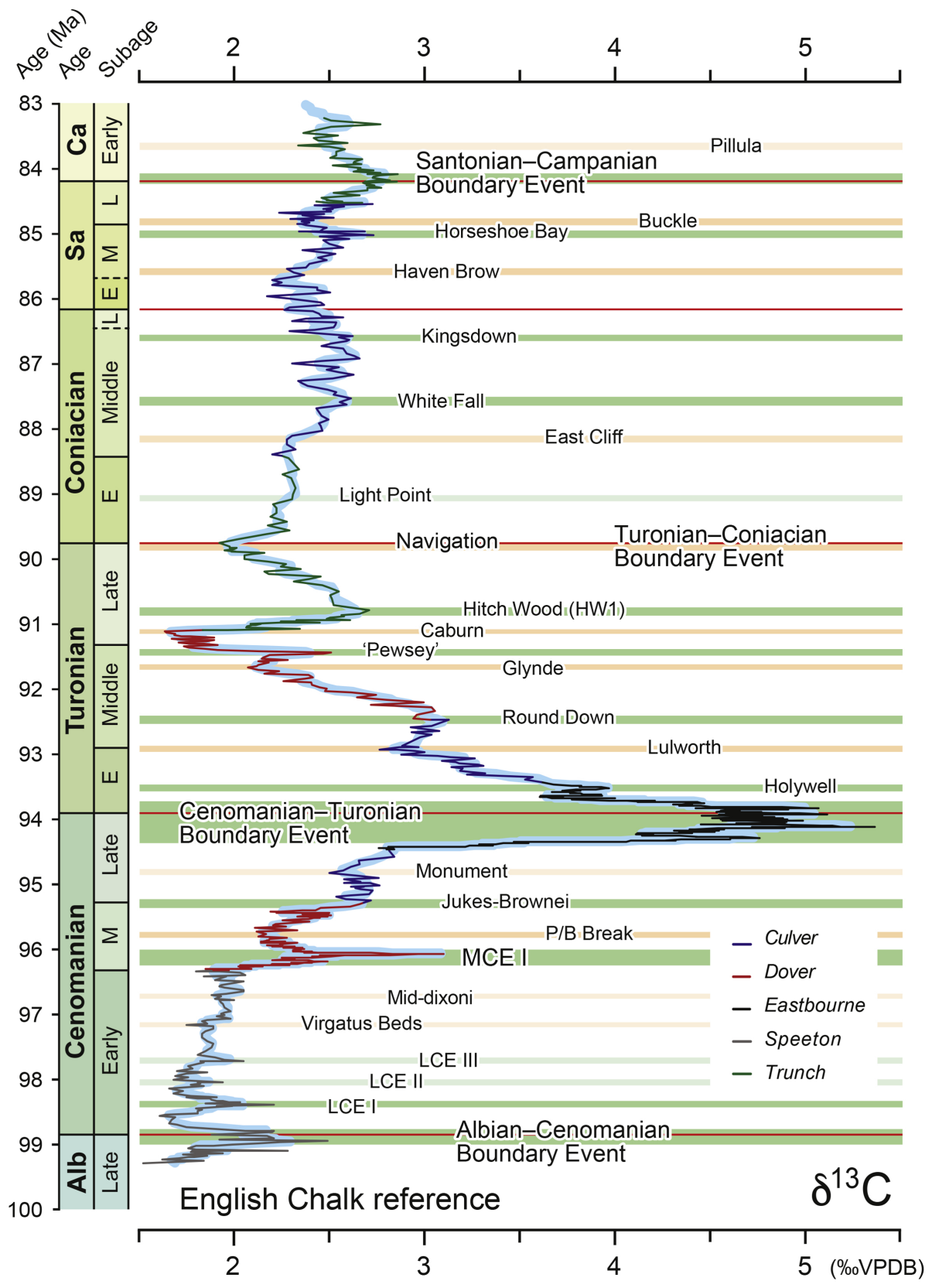



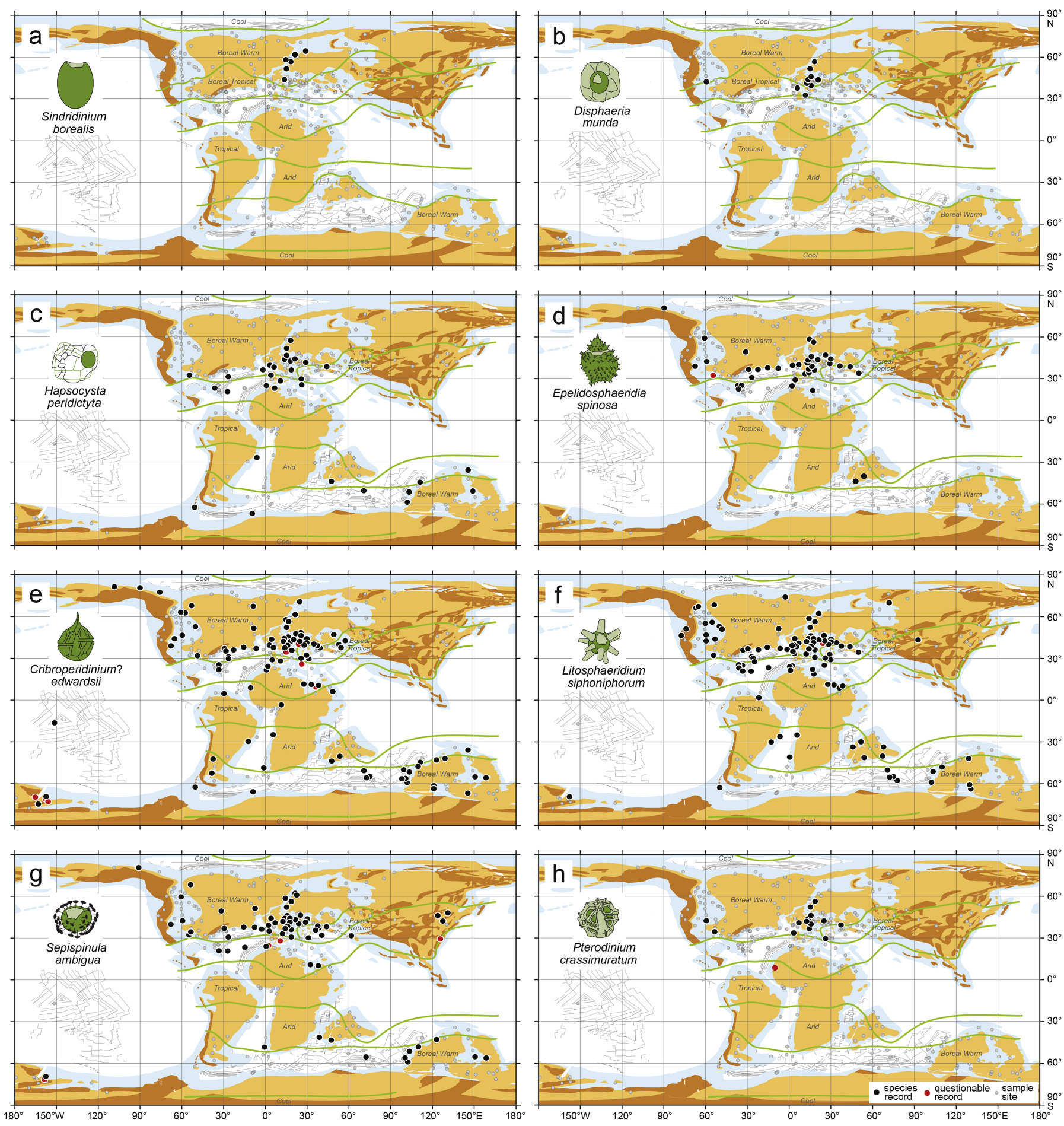

Figure 10 


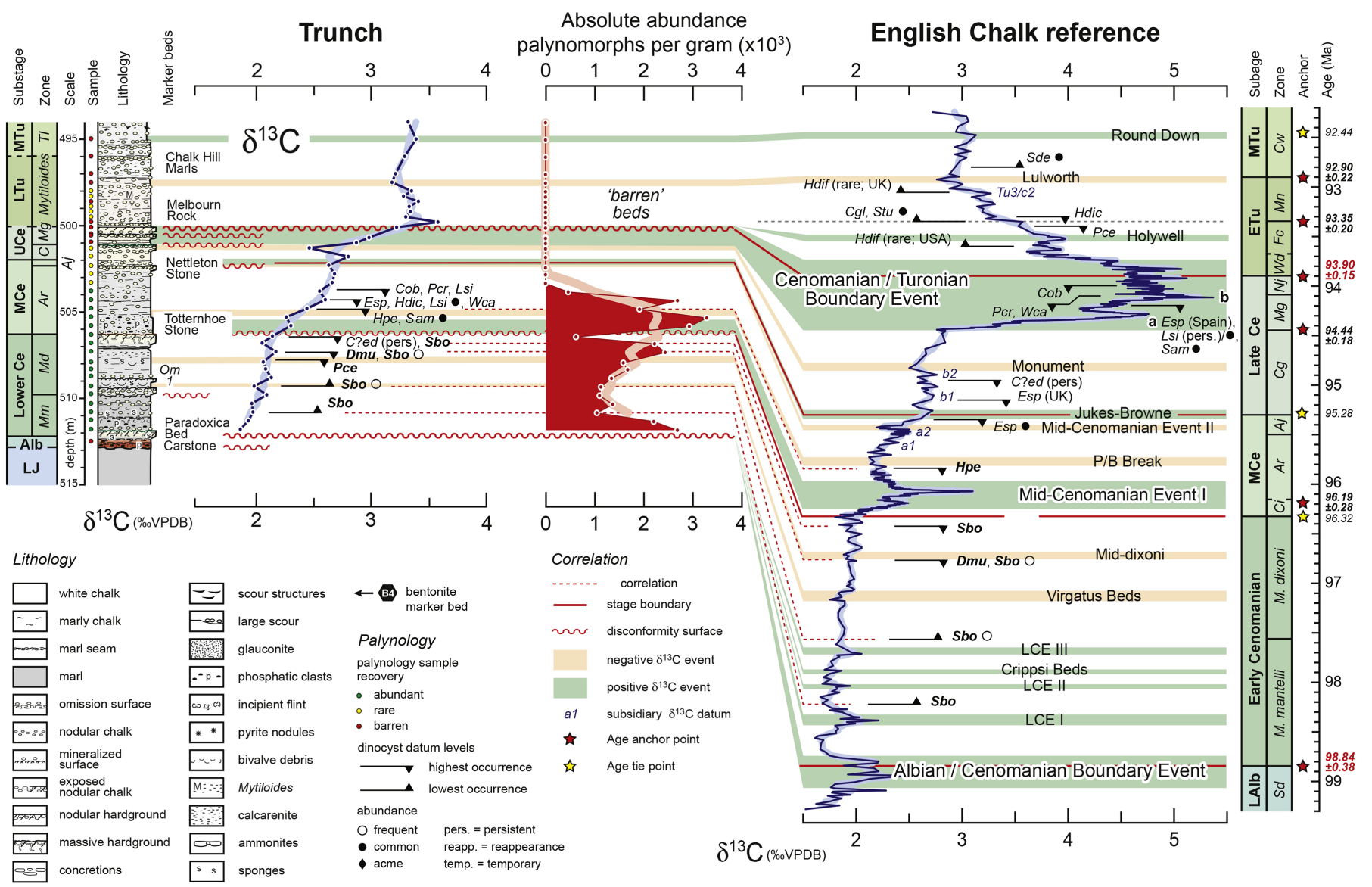




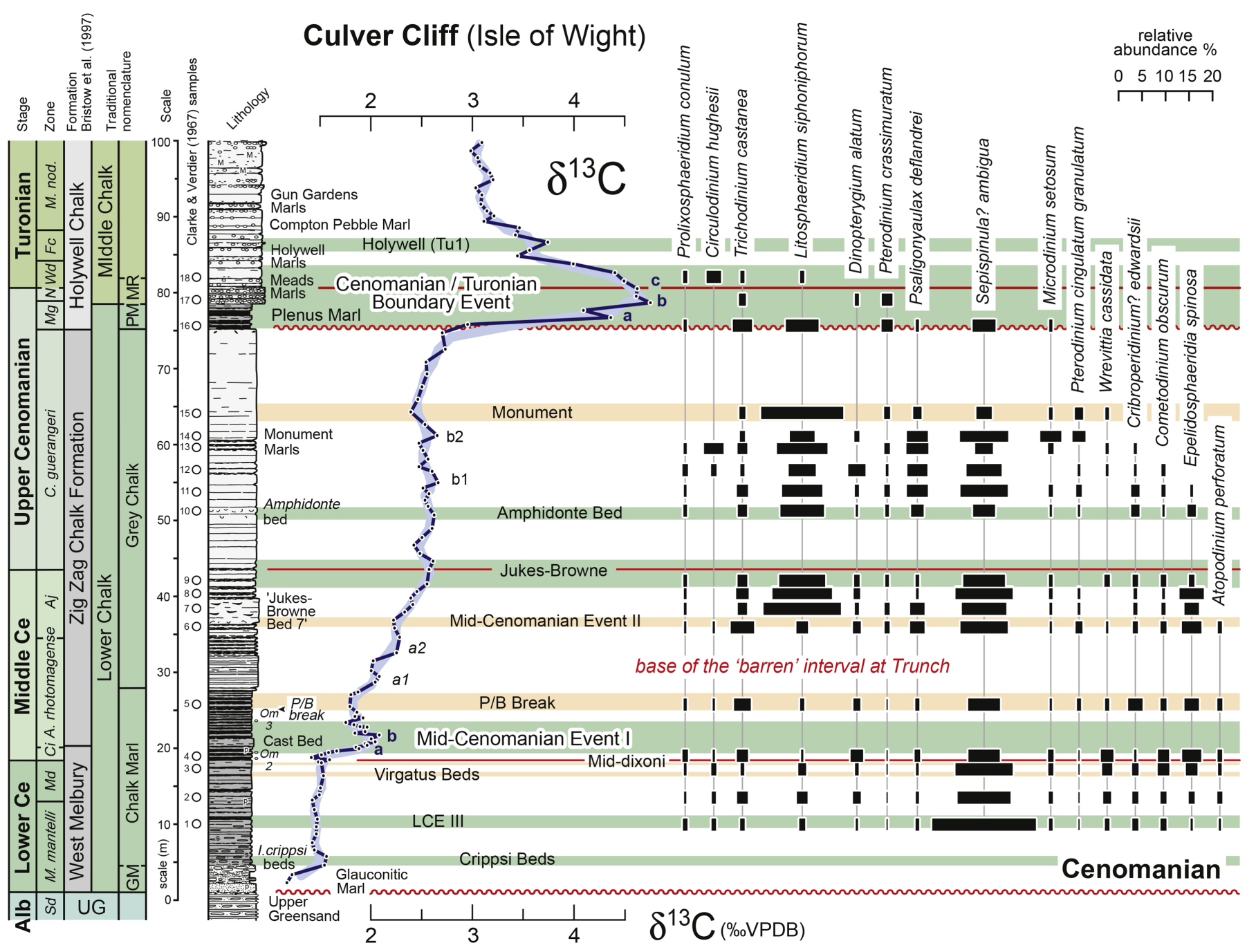

Figure 12 

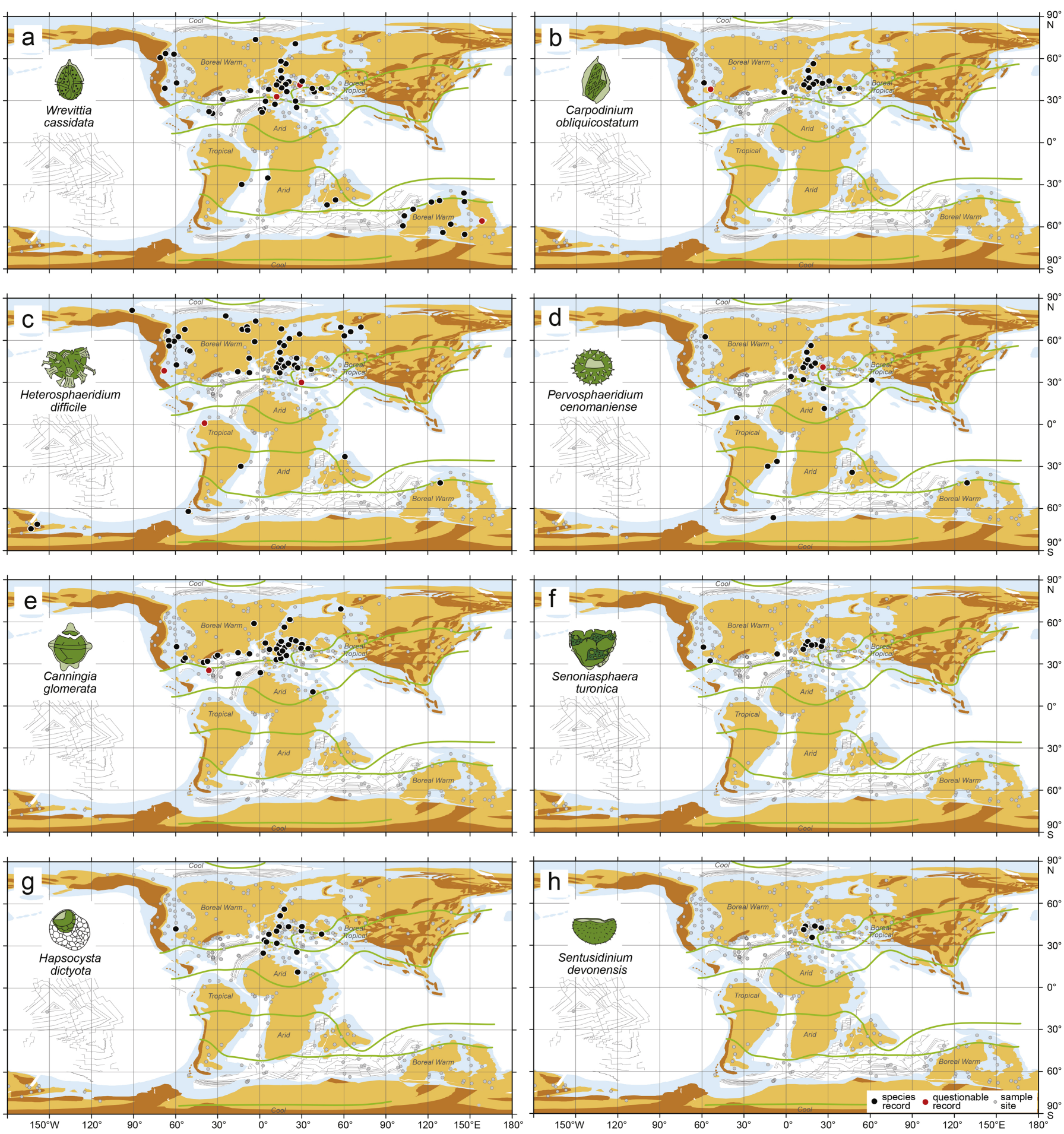

Figure 13 


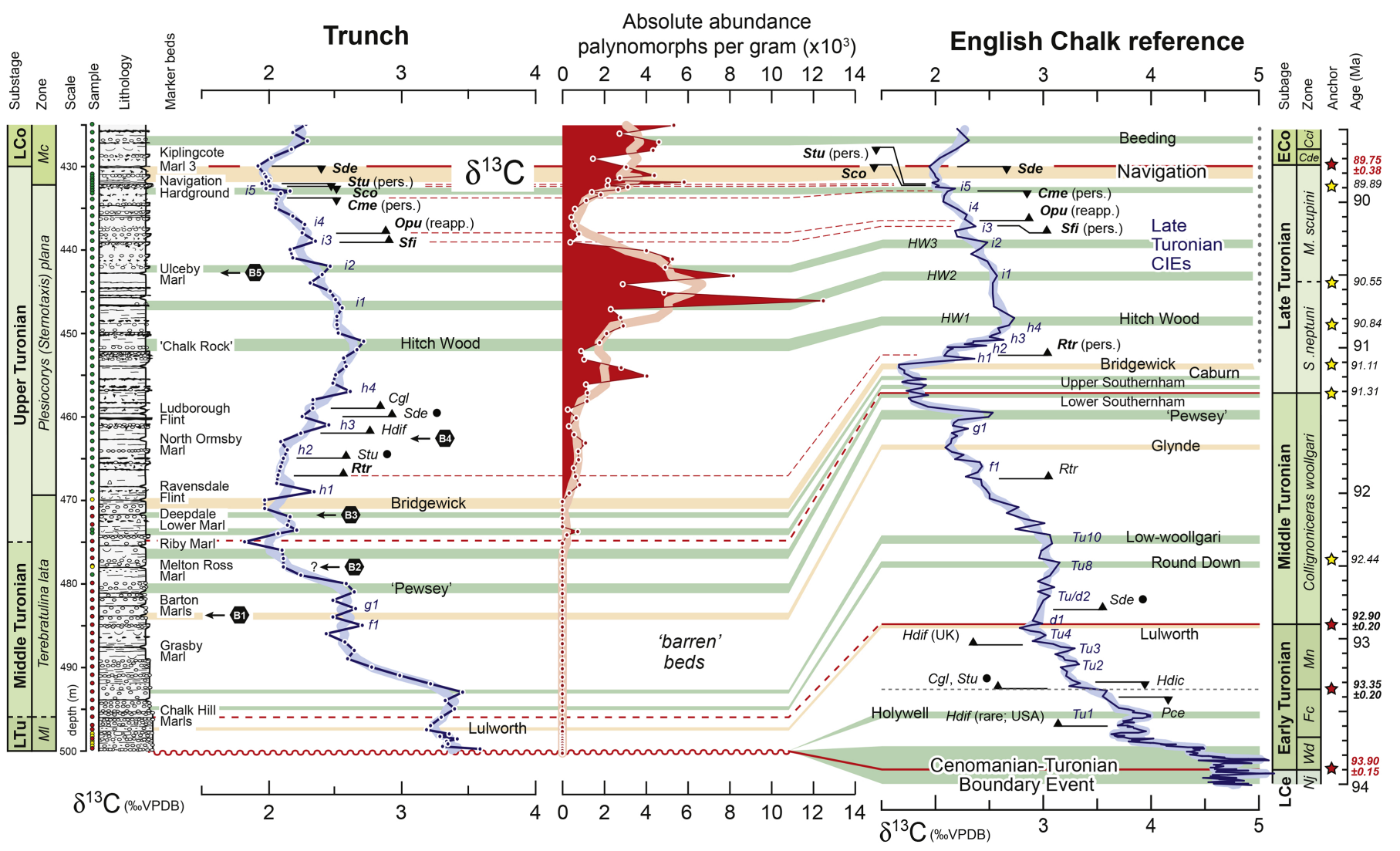

Figure 14 

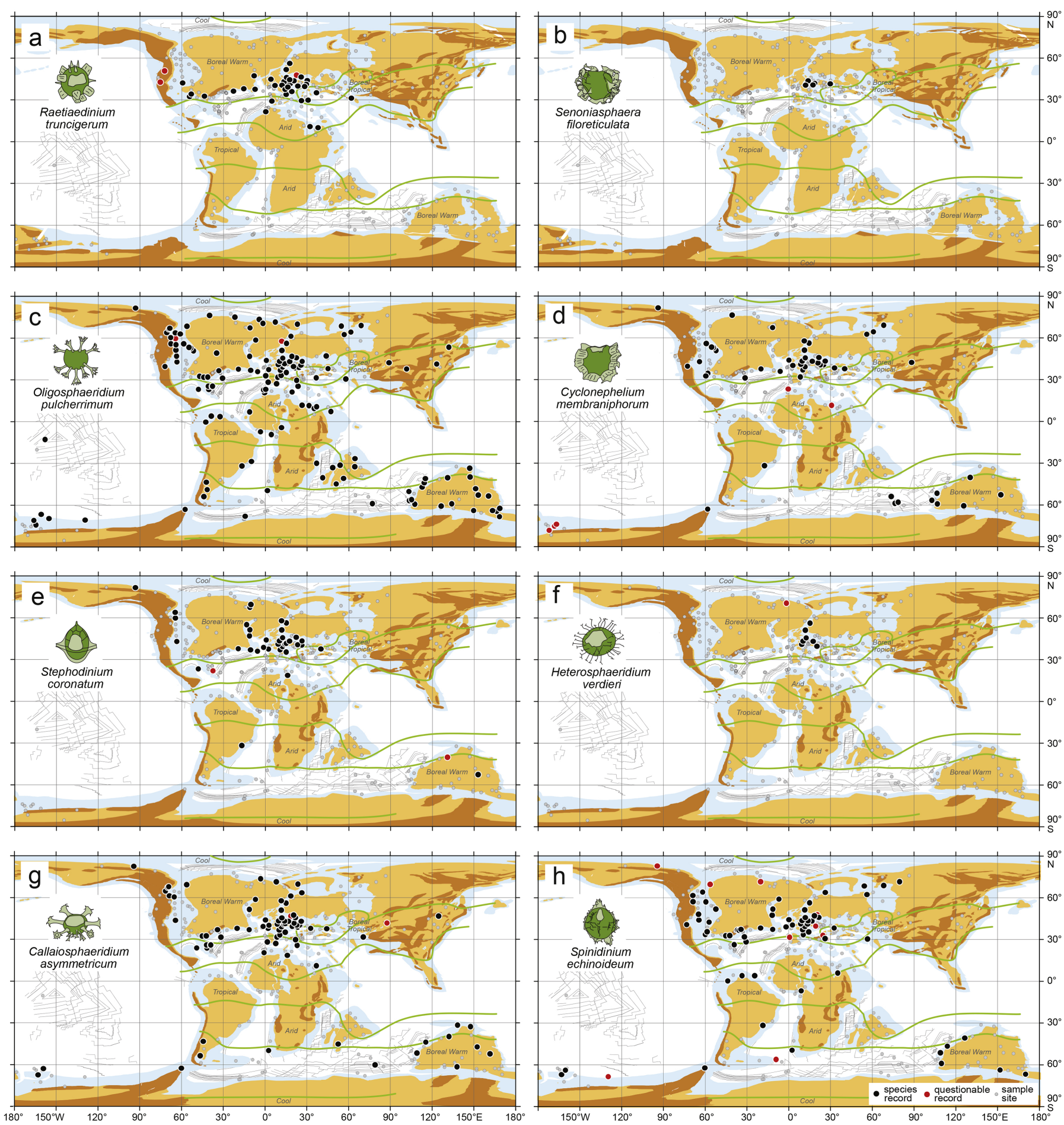

Figure 15 


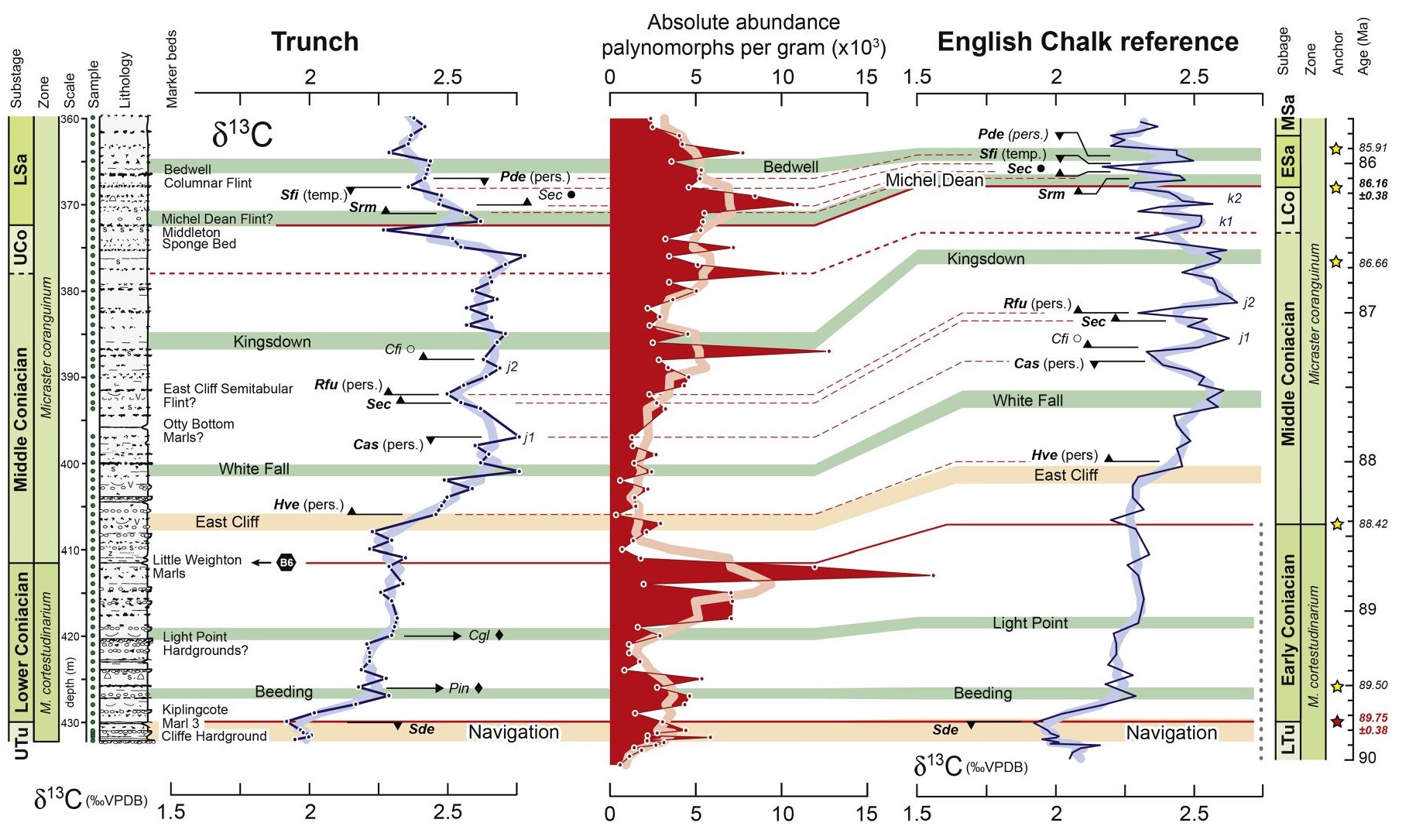



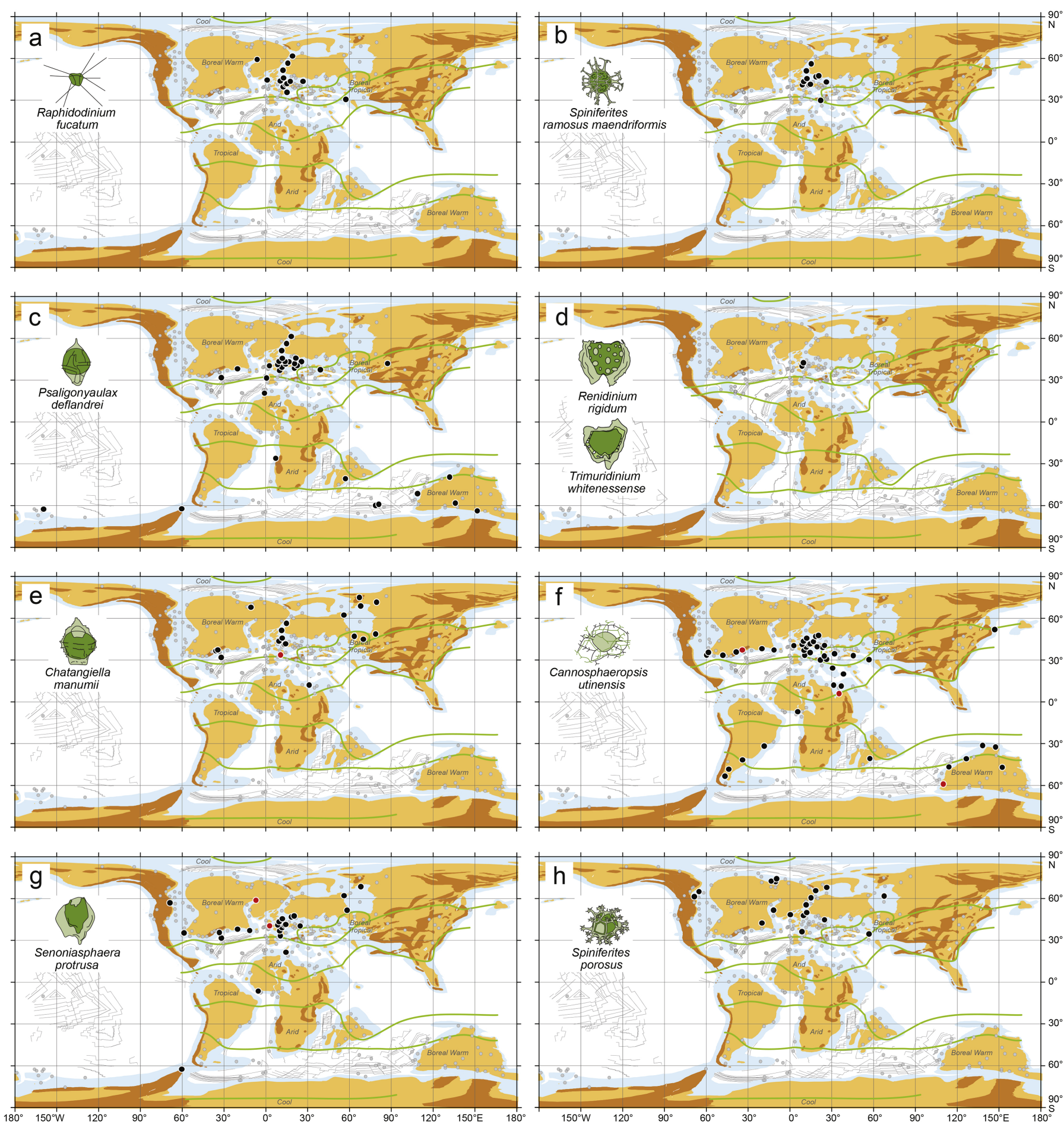

Figure 17 


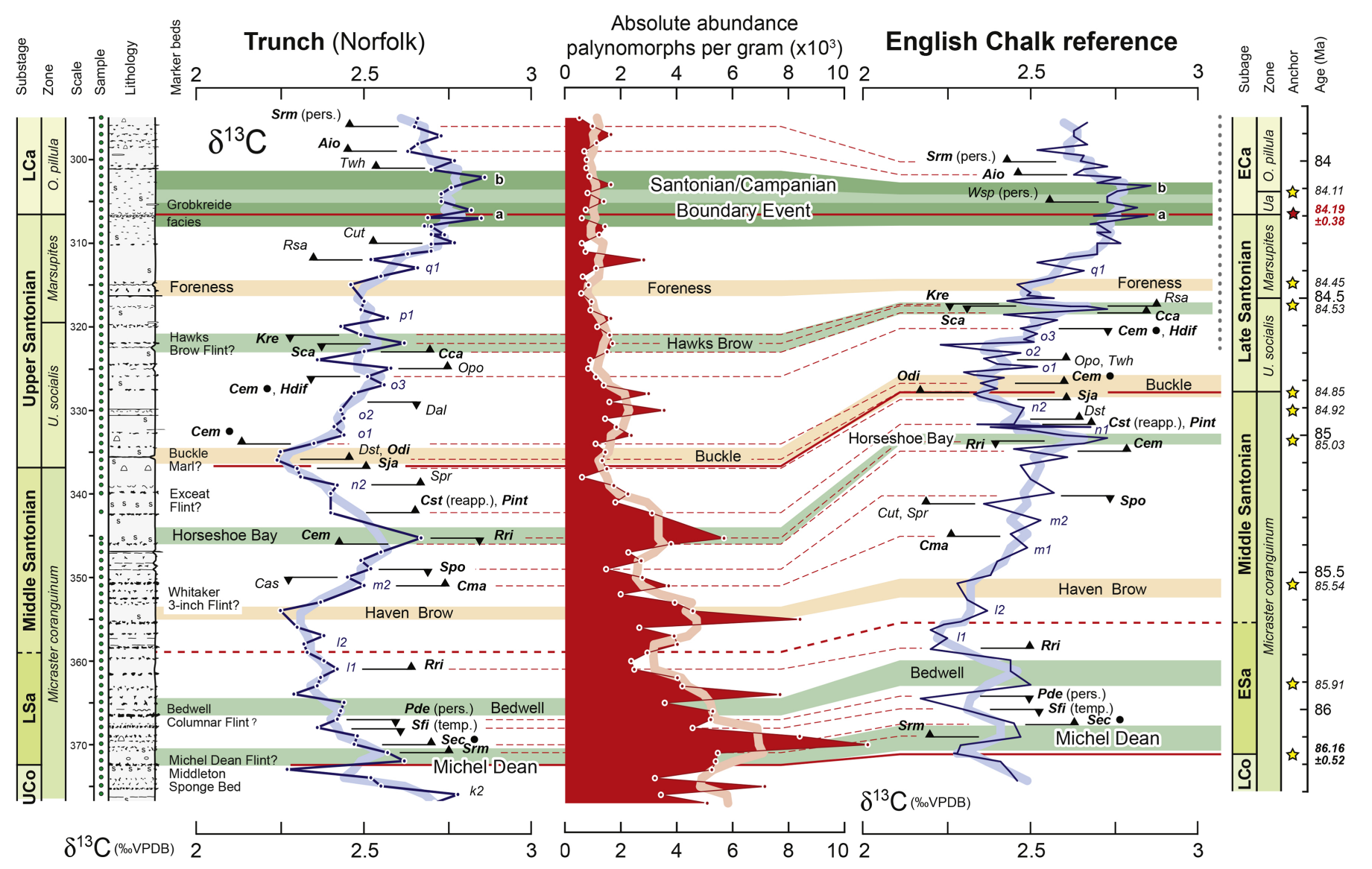

Figure 18 

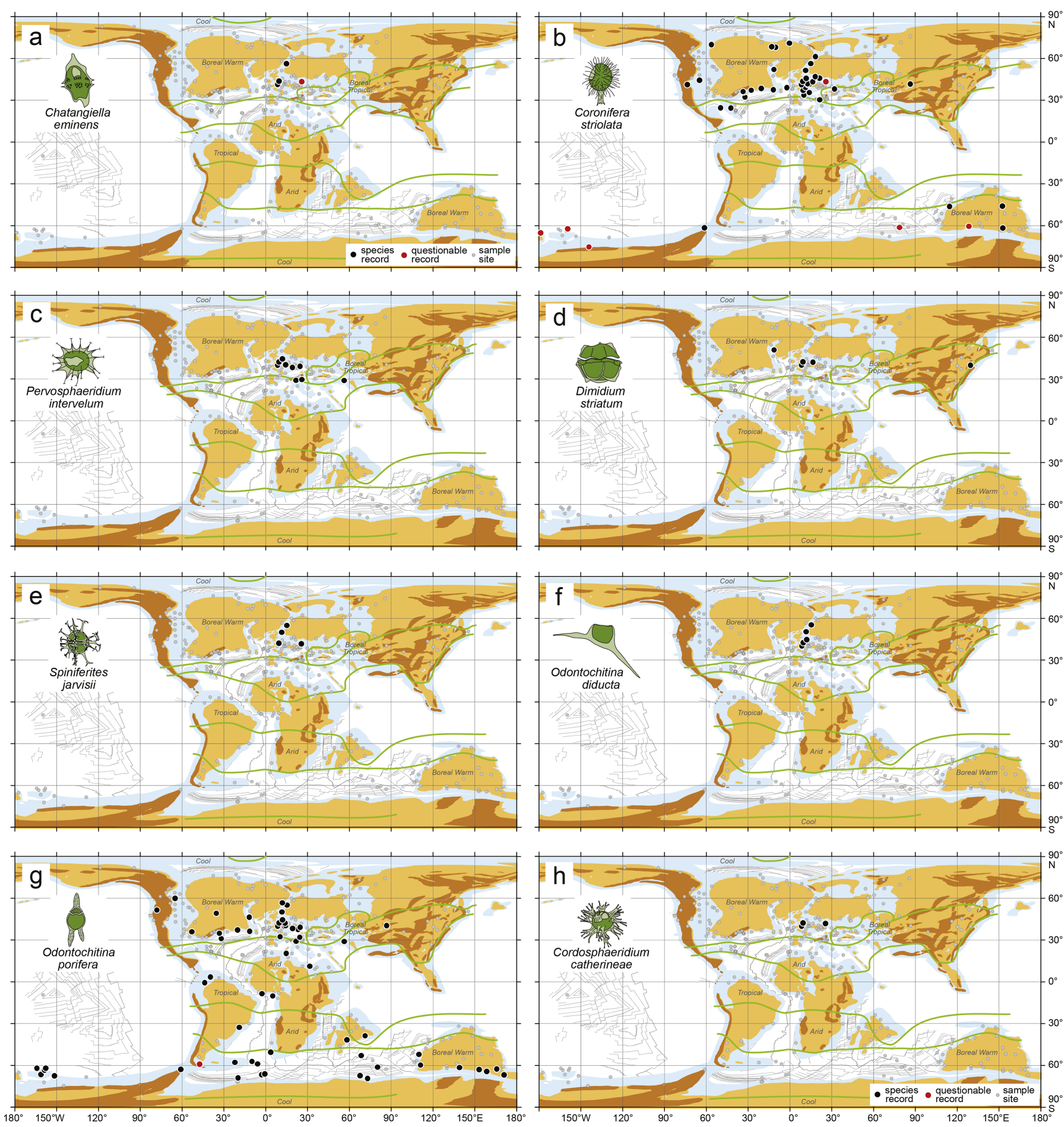

Figure 19 

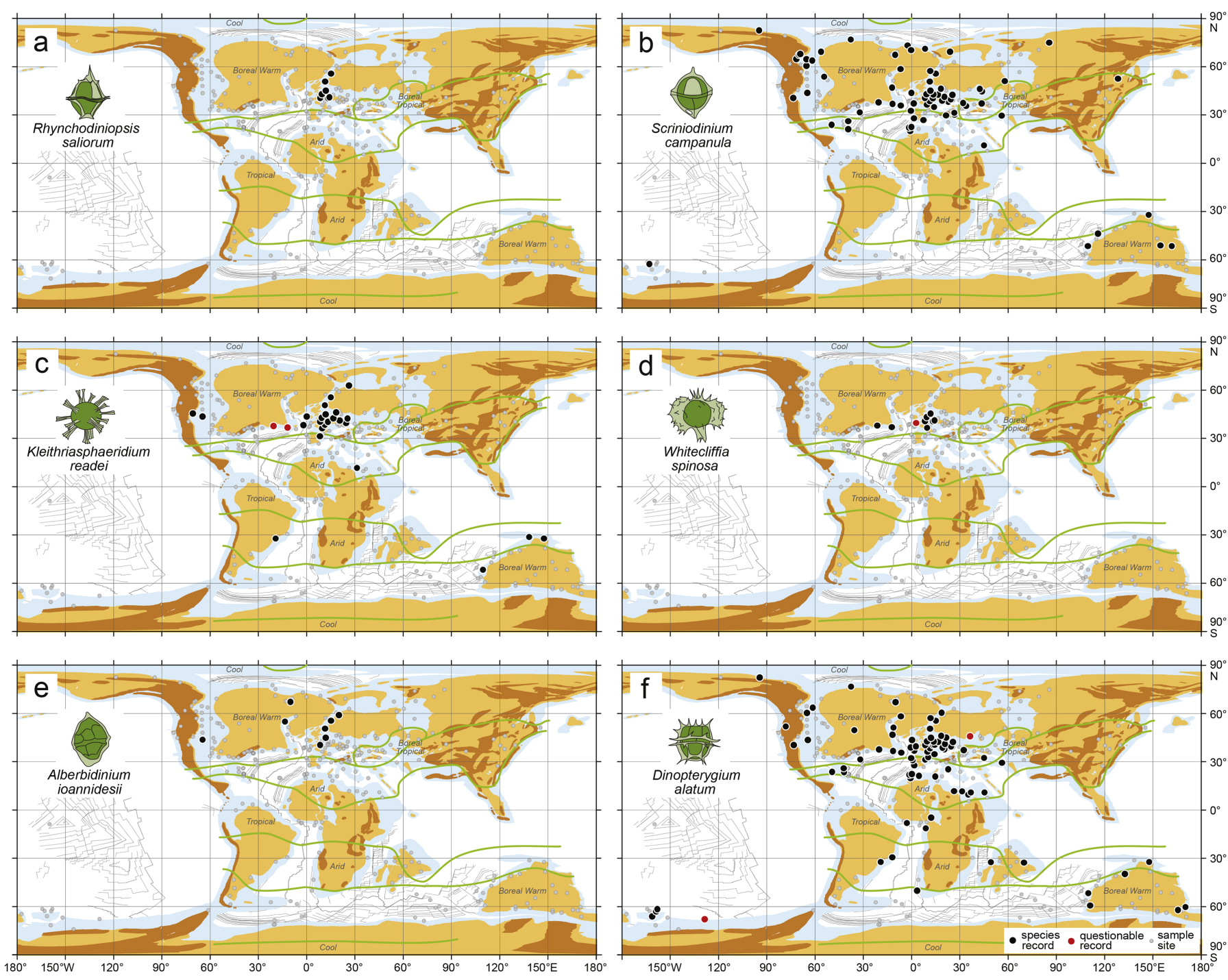

Figure 20 


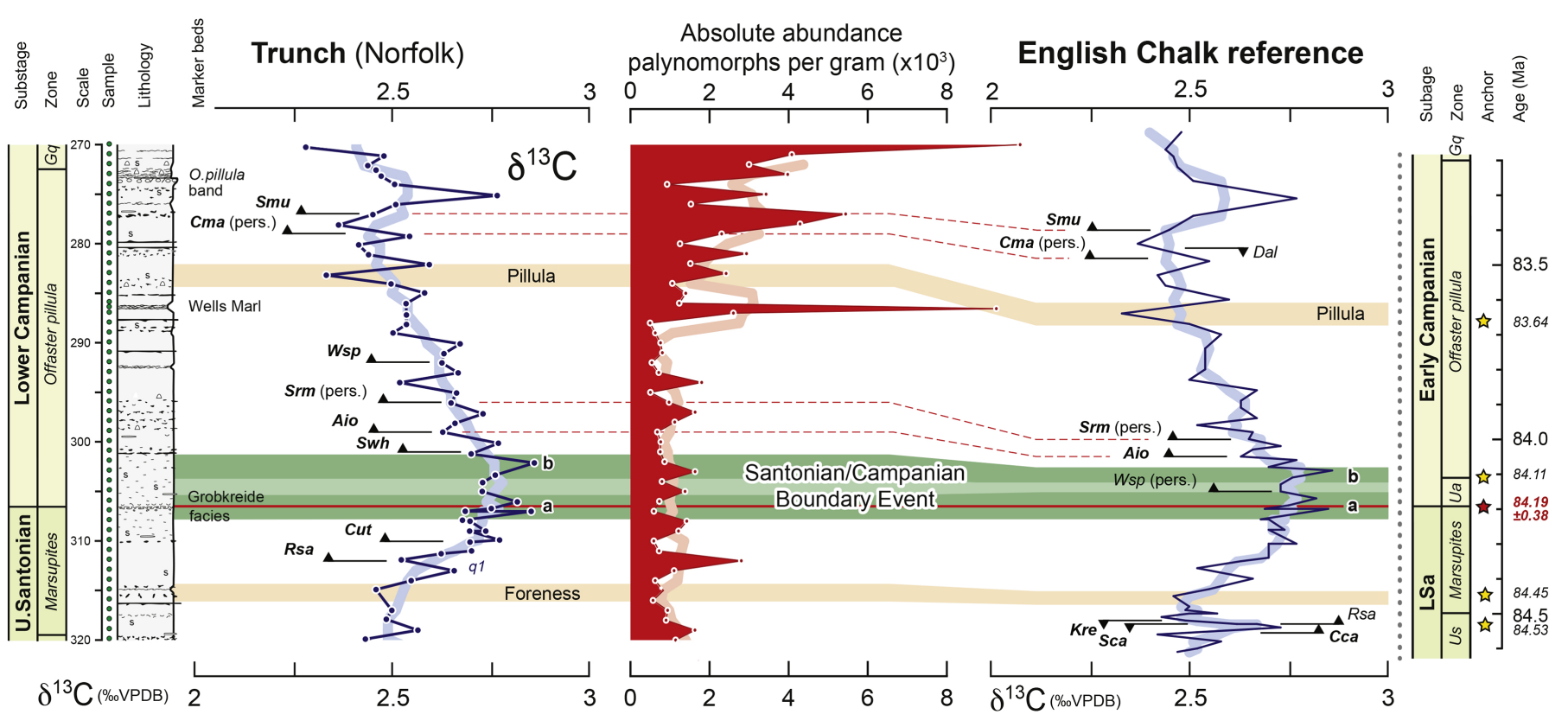

Figure 21 


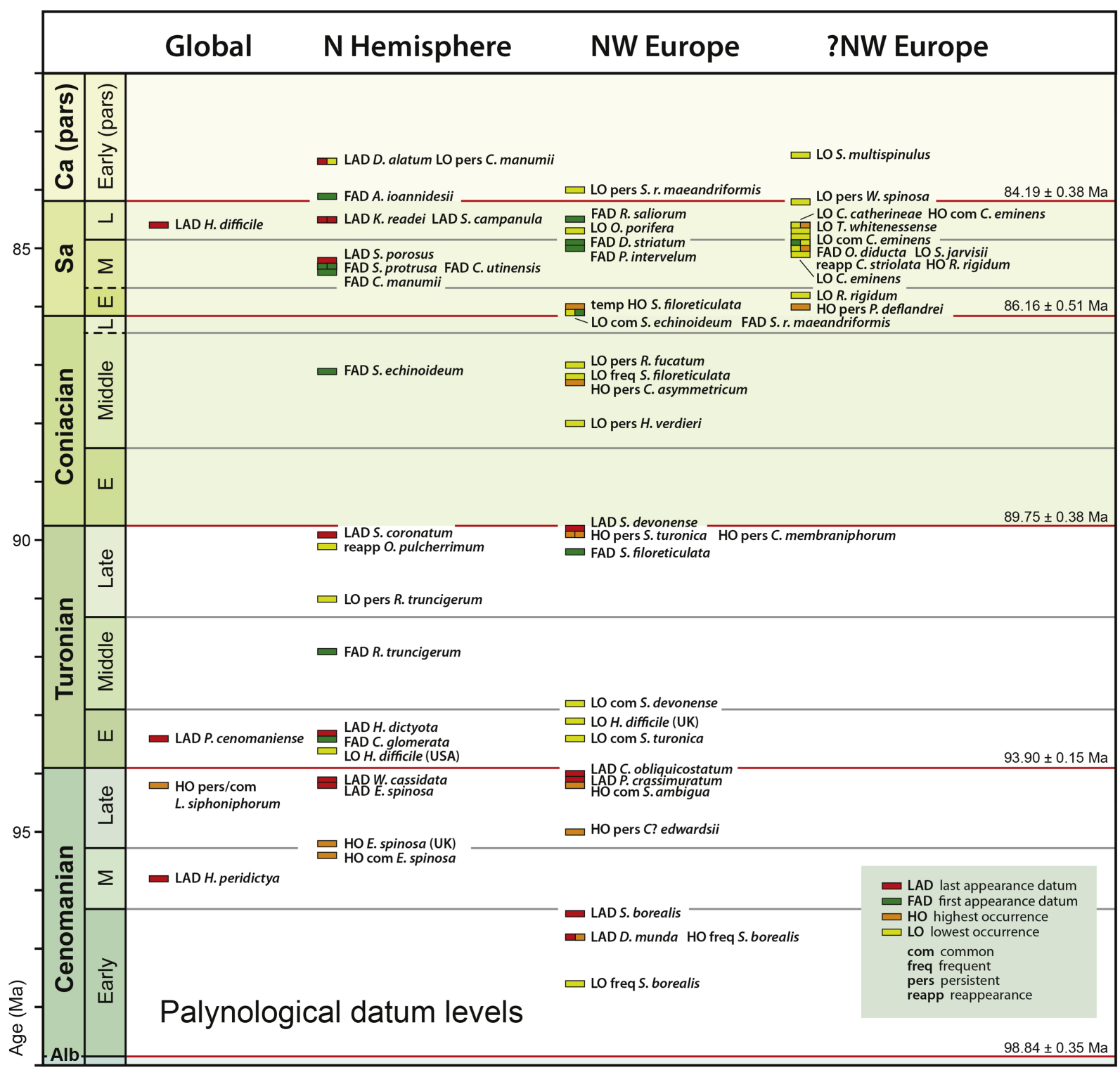




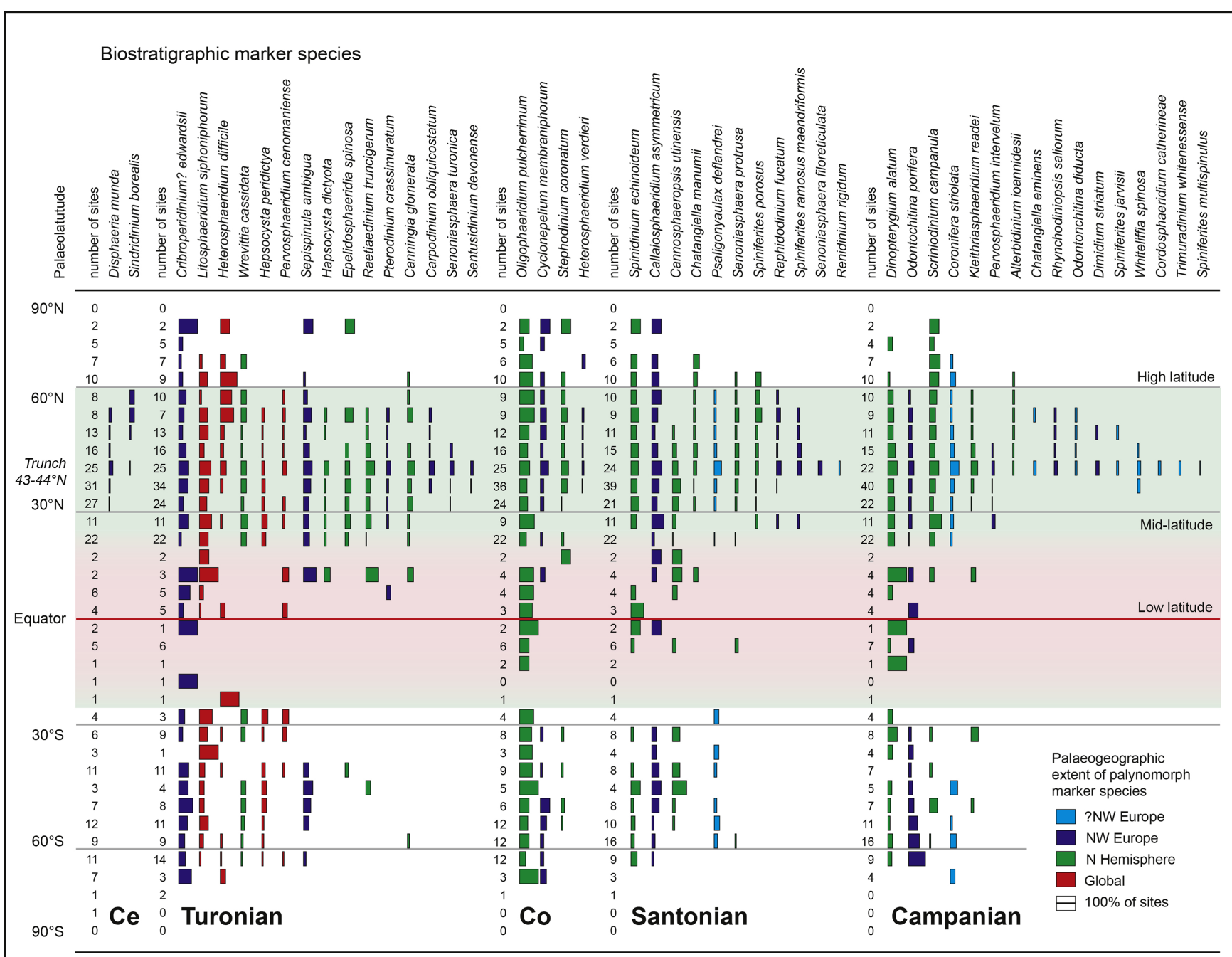

Figure 23 